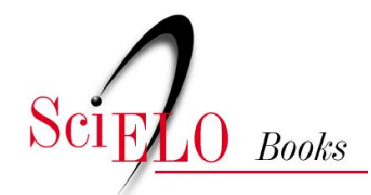

\title{
Paisagens sígnicas
}

uma reflexão sobre as artes visuais contemporâneas

\author{
Maria Celeste de Almeida Wanner
}

WANNER, MCA. Paisagens sígnicas: uma reflexão sobre as artes visuais contemporâneas [online]. Salvador: EDUFBA, 2010. 302 p. ISBN 978-85-232-0883-7. Available from SciELO Books $<$ http://books.scielo.org $>$.

\section{(1) (1) $\Theta(9)$}

All the contents of this work, except where otherwise noted, is licensed under a Creative Commons Attribution-Non Commercial-ShareAlike 3.0 Unported.

Todo o conteúdo deste trabalho, exceto quando houver ressalva, é publicado sob a licença Creative Commons Atribuição Uso Não Comercial - Partilha nos Mesmos Termos 3.0 Não adaptada.

Todo el contenido de esta obra, excepto donde se indique lo contrario, está bajo licencia de la licencia Creative Commons Reconocimento-NoComercial-CompartirIgual 3.0 Unported. 


\section{Paisagens Sígnicas:}

Uma reflexão sobre as artes visuais contemporâneas 


\section{UNIVERSIDADE FEDERAL DA BAHIA}

Reitor

Naomar Monteiro de Almeida Filho

Vice Reitor

Francisco José Gomes Mesquita

\section{EDITORA DA UNIVERSIDADE FEDERAL DA BAHIA}

Diretora

Flávia Goullart Mota Garcia Rosa

CONSELHO EDITORIAL

Titulares

Ângelo Szaniecki Perret Serpa

Caiuby Alves da Costa

Charbel Ninõ El-Hani

Dante Eustachio Lucchesi Ramacciotti

José Teixeira Cavalcante Filho

Alberto Brum Novaes

Suplentes

Antônio Fernando Guerreiro de Freitas

Evelina de Carvalho Sá Hoisel

Cleise Furtado Mendes

Maria Vidal de Negreiros Camargo

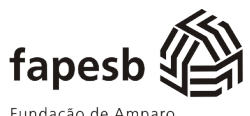




\section{Paisagens Sígnicas:}

Uma reflexão sobre as artes visuais contemporâneas

Maria Celeste de Almeida Wanner

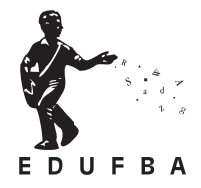

Salvador

2010 
C2010 by Maria Celeste de Almeida Wanner

Direitos para esta edição cedidos à Editora da Universidade Federal da Bahia.

Feito o depósito legal.

\author{
PROJETO GRÁFICO E DIAGRAMAÇÃO \\ Genilson Lima Santos \\ CAPA \\ Maria Celeste de Almeida Wanner \\ REVISÃO DE TEXTO E NORMALIZAÇÃO \\ Cida Ferraz
}

Sistema de Bibliotecas - UFBA

Wanner, Maria Celeste de Almeida.

Paisagens sígnicas : uma reflexão sobre as artes visuais contemporâneas / Maria

Celeste de Almeida Wanner. - Salvador : EDUFBA, 2010.

$302 \mathrm{p}$.

ISBN 978-85-232-0672-7

1. Paisagem na arte. 2. Arte moderna. 3. Natureza (Estética). 4. Semiótica. 5. Sinais e símbolos. I. Título.

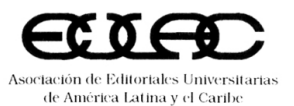

de America Lat lina y il Carile.

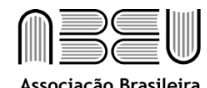

Associação Brasileira das Editoras Universitárias
$\mathrm{CBaL}$

EDUFBA Rua Barão de Jeremoabo, s/n Campus de Ondina,

Salvador - Bahia CEP 40170115 Tel/fax 7132836164

www.edufba.ufba.br edufba@ufba.br 
A meus Pais e Dinda, amor recíproco e incondicional. A meu neto Joaquim, milagre da vida, onde tudo recomeça, segundo Novalis, amor feito visível. 



\section{AGRADECIMENTOS}

À minha supervisora Prof ${ }^{a} \operatorname{Dr}^{a}$ Lucia Santaella, exemplo de elegância profissional, vitalidade e disposição intelectual contagiante, sempre atenta aos assuntos mais novos e familiaridade com os mais clássicos. Constante companheira, desde os primeiros momentos do projeto. Lucia, aqui expresso minha maior e eterna gratidão, sempre!

Ao Prof. Dr. Ivo Assad lbri, pelo papel fundamental que desempenhou no impulso à minha pesquisa, com entusiasmo ao repassar seus conhecimentos sobre a filosofia de Charles Sanders Peirce e a filosofia da natureza.

Presto meus sinceros agradecimentos ao Conselho Nacional de Desenvolvimento Científico e Tecnológico (CNPq), pelo continuado apoio à minha formação acadêmica e de pesquisa, desta vez como bolsista Pós-Doutorado Sênior (PDS), 2007-2008.

À Fundação de Apoio à Pesquisa do Estado da Bahia (Fabesp), pelo patrocínio deste livro.

Ao Programa de Estudos Pós-Graduados de Comunicação e Semiótica da Pontifícia Universidade Católica de São Paulo (PUC/SP), por ter me acolhido em um espaço de pesquisa acadêmica, o que para mim foi um grande privilégio.

A todos os colegas e amigos do Grupo de Pesquisa sobre Pragmatismo (PUC/São Paulo/CNPq), representados na pessoa de Tiago da Costa e Silva, pelo prazer em trabalharmos juntos. 


\section{Especiais agradecimentos:}

À Prof ${ }^{a}$ Dr ${ }^{a}$ Cecília Salles (PUC/SP) e ao Prof. Dr. Vincent Colapietro, research professor of Philosophy at Penn State University, EUA, presidente do Peirce Edition Project, pelas valiosas discussões.

Às professoras Diana Sepúlveda Tourinho, Flávia Garcia Rosa e toda a equipe da Editora da Universidade Federal da Bahia (Edufba), por terem acolhido meu trabalho, com profissionalismo e excelência. A Cida Ferraz, pela impecável revisão final, fruto de seu entusiasmo pelas artes e letras.

À bibliotecária da Escola de Belas Artes da Universidade Federal da Bahia (EBA/Ufba), Leda Maria Ramos Costa, pela primeira normalização bibliográfica.

Aos colegas do Grupo de Pesquisa Arte Híbrida (Ufba/CNPq), e a todos os queridos alunos e ex-alunos (graduação e pós-graduação), aqui representados por Eriel Araújo, Bia Santos, Tonico Portela e Virgínia Medeiros, pela demonstração de carinho, alegria, sobretudo por suas inquietações que me levaram à constante pesquisa sobre a Arte.

Aos amigos de sempre, incentivadores neste projeto: Maerbal Marinho, Cleomar Rocha, Maria Vidal, Célia Maria Barreto Gomes e Fernando Freitas Pinto e Eduardo Baioni.

Avayvwpí̧w ayantriós lannis Mastronikolis, por ter trazido à tona uma das mais lindas lembranças que guardo até hoje da minha infância, a cultura grega.

A Marta Gmeiner e Clara Wanner.

A meu querido irmão Miguel. Aos meus amados filhos Julia e Joaquim.

A meus pais, exemplos de coragem, amor, determinação e respeito incondicional pelas diferenças do outro. 


\section{CORRESPONDÊNCIAS}

A natureza é um templo onde vivos pilares

Deixam filtrar não raro insólitos enredos;

O homem o cruza em meio a um bosque de segredos

Que ali o espreitam com seus olhos familiares.

Como ecos longos que à distância se matizam

Numa vertiginosa e lúgubre unidade,

Tão vasta quanto a noite e quanto a claridade,

Os sons, as cores e os perfumes se harmonizam.

Há aromas frescos como a carne dos infantes, Doces como o oboé, verdes como a campina,

E outros, já dissolutos, ricos e triunfantes,

Com a fluidez daquilo que jamais termina, Como o almíscar, o incenso e as resinas do Oriente, Que a glória exaltam dos sentidos e da mente.

Charles Baudelaire 



\section{SUMÁRIO}

\section{PREFÁCIO:}

A ética de curiosidade, Lucia Santaella 13

\section{UM ENCONTRO COMO ADMIRÁVEL 17}

2. UMA REFLEXÃO SOBRE A FILOSOFIA DE C. S. PEIRCE 25

Fenomenologia 28

Estética 32

Ética 35

Lógica ou Semiótica 36

Signo 38

Objeto 41

Ícone, Índice e Símbolo 43

Metafísica 44

Pragmatismo e Semiose 44

Charles Sanders Peirce: uma possível Filosofia da Natureza 47

3. REPRESENTAÇÃO 53

Natureza 61

Paisagem - Landscape 66

Natureza da Arte: Martin Heidegger 74

Espaço-Tempo-Lugar 83

4. ÍNDICES DE CONTEMPORANEIDADE NAS ARTES VISUAIS 95

Assinatura do Modernismo: primeiro conceito de Vanguarda 95

O advento da Fotografia e sua relação com a Pintura 99

A crise da Pintura - Vincent van Gogh 102

A Fotografia e seu processo de elevação à categoria Arte 109

Alfred Stieglitz 112

Edward Weston 114

Ansel Adams 114

Período Modernista 116

Alegoria, Colagem e Fotomontagem 120

Arte no barulho de um motor 121

Construtivismo 126

A travessia do Atlântico: Europa e América 129

Jackson Pollock: quadro ação 134

Paisagem dos Signos - Paisagem das Mídias 141

Arte Cinética: o espaço na obra de Calder 148 
5. REPENSANDO A REPRESENTAÇÃO 155

Do Moderno ao Contemporâneo 156

Desconstrução 158

Isto não é um cachimbo e Canyon 164

Isto é real ou é arte? 168

Por que alguma coisa é arte enquanto outra não é? 171

Depois do fim da Arte: Arthur C. Danto 172

Apropriação e outros conceitos 177

Multiculturalismo 186

Paradigma da Matéria 193

A Crise do Espaço nas Artes Plásticas 196

Escultura 196

Temporalidade e Duração da Experiência 200

Earth Art 204

Instalação 207

6. PERÍODO PLURALISTA: REMEMORAÇÃO 209

Por que Richard Serra? 212

Do Artesanato à Arte 217

O Corpo está em Cena 219

Tecidos, Roupas e Bronze 222

Kiki Smith 223

Louise Bourgeois 226

7. A IMAGEM REVISADA 231

Fotografia: Espelho e Janela 232

Apropriação na Fotografia 235

A Fotografia depois da Fotografia 240

Andreas Gursky 244

Spencer Tunick 246

Atta Kim 247

Misha Gordin 248

A humanização da máquina e o pensamento oriental 250

8. O RETORNO À NATUREZA E AO SUBLIME 257

Agnes Denes: Campos de Trigo - uma confrontação 257

Campos de Girassóis: Anselm Kiefer e Vincent van Gogh 262

Anselm Kiefer e Van Gogh no Sul da França 269

REFERÊNCIAS 277 


\section{PREFÁCIO}

\section{A ética de curiosidade}

Vivemos em um mundo hipercomplexo: na economia, política e, sobretudo, na cultura. Um mundo que repele julgamentos peremptórios e a segurança das certezas. Zigmund Bauman ficou famoso ao chamar e caracterizar esse mundo com o adjetivo líquido: modernidade líquida, vida líquida, amor líquido, medo líquido. Que o amor seja líquido, não espanta. Mas se até o medo se tornou líquido, o que sobra de sólido? Em outra ocasião (Linguagens líquidas na era da mobilidade, 2007, p. 131-136), para responder à pergunta "em que cultura vivemos", esbocei algumas de suas propriedades: nossa cultura é global e glocal, é híbrida e cíbrida, é conectada, ubíqua e nômade, é líquida, fluida, volátil. É, em suma, uma cultura mutante.

Como poderia a arte, que sempre foi, é e será, sinalizadora, farol e antena dos movimentos, da vida e das pulsações da cultura, estar fora dessas mutações? Jamais. Ao contrário, palpita por todos os cantos e esquinas, centros e bordas da cultura. Se quisermos saber para onde sopram os ventos vivos da cultura, é preciso se acercar da arte, por mais complexa que ela nos pareça, como, de fato, está, não só complexa, mas hipercomplexa.

Há arte dos artefatos, dos objetos, da matéria, dos sítios específicos, da terra e do pó.

Há arte do céu e do espaço.

Há arte dos não-objetos, dos imateriais, da luz e da brisa.

Há arte da construção e da desconstrução, da representação e da anti-representação, da anti-arte e do além da arte.

Há arte do espetacular e do escondido, do barulho e da discrição.

Há arte do gesto que fica e do gesto que desvanece, da ação e do silêncio.

Há arte do objeto único, do distributível, do reprodutível, do transmissível e da ubiquidade. 
Há arte pré-mídia, midiática e pós-mídia. Pré-fotográfica, fotográfica e pós-fotográfica.

Há arte contemplativa, reativa, participativa, interativa, colaborativa.

Enfim, a arte hoje transborda todos os limites. Incategorizável. Não existe quem possa erguer a tábua de critérios válidos contra os inválidos para o fazer da arte. Partir para a denúncia do "vale-tudo" também não nos leva longe. Pior ainda, pode nos cegar para sementes que brotam em terrenos inesperados.

Diante da desmesurada densidade das diferenças, cumpre colocar em prática a ética da curiosidade. Não para cultivar a esperança de que possamos abraçar o mapa variegado do todo, mas para que, libertos de crenças e valores fixos, possamos traçar trilhas, estabelecer recortes, sempre contingentes, pois a ética da curiosidade impõe-se contra seus grandes inimigos: a preguiça e a inércia das verdades prontas.

Se há um atributo que poderia dar conta da apresentação desta obra de Celeste Almeida, a meu ver, este se encontra na maneira como a autora pratica a ética da curiosidade. Não se trata, evidentemente, de uma curiosidade sem rumo, mas sim ancorada em anos de experiência como artista e como professora. Plagiando Pound, poderíamos dizer: "se quiser saber alguma coisa sobre arte, pergunte a um(a) artista". Em especial a um(a) artista compromissado(a) com a transmissão do fazer e do saber sobre a arte. Neste livro, à atividade da artista e da mestra adiciona-se a da pesquisadora.

Seu objeto lhe era caro: a relevância da matéria nas artes atuais. O tema lhe era claro: as transfigurações estéticas da natureza e da paisagem. Para acercar-se deles, era preciso traçar os lugares da arte no último século, tarefa enredada que só podia ser cumprida com a sonda de uma curiosidade multidirecional, capaz de captar sinais ontológicos, epistemológicos, semióticos e estéticos. As paisagens da arte se constroem da arte e na arte. Ao fim e ao cabo, são paisagens sígnicas.

A história da arte, especialmente do final do século XIX para cá, não conhece linhas retas. É feita de ecos, reverberações, rememorações, traduções, confrontos, projeções, reflexos e refrações. Esse traçado multiforme, 
pontilhado de reflexões apoiadas em autores selecionados, fios que aparecem, desaparecem e reaparecem, é o que o leitor terá oportunidade de encontrar nesta obra. Um recorte próprio e um traçado personalizado na densa e inesgotável floresta de signos da arte contemporânea.

Lucia Santaella

São Paulo, dezembro de 2009 



\section{UM ENCONTRO COM O ADMIRÁVEL}

Paisagens Signicas: uma reflexão sobre as artes visuais contemporâneas é fruto de pesquisa desenvolvida nos últimos 17 anos e aprofundada durante o Pós-Doutorado em Semiótica e Artes Visuais Contemporâneas, na Universidade Pontifícia Católica de São Paulo (PUC/SP), como bolsista sênior do Conselho Nacional de Desenvolvimento Científico e Tecnológico (CNPq), sob a supervisão da Profa. Dra. Lucia Santaella.' O desejo de transformar em livro o extenso material já existente sobre a importância da matéria e do espaço nas artes visuais contemporâneas foi acolhido e

1 Trata-se, portanto, de um desdobramento do projeto Antena e Raiz, que, voluntariamente, ou seja, não exigido pelos órgãos superiores (CNPq e PUC/SP), foi além do relatório final. 
incentivado por Lucia Santaella - e então revisitado à luz da filosofia de Charles Sanders Peirce.

O que aqui denominamos de arte contemporânea é um conjunto de sistemas visuais que se desenvolveu a partir do final do século XIX, através do processo de desconstrução dos meios tradicionais de representação (pintura e escultura) - que incluem materiais e espaços considerados lógicos nas artes plásticas -, em decorrência do advento da fotografia. Esse marco encontra ressonância no âmbito da sociedade pré-moderna do final do século XIX, fundando correspondências entre as novas maneiras de representação sígnica, com destaque para a estreita relação, então estabelecida, entre o homem e a natureza e uma determinada visão de mundo.

Com o surgimento da imagem fixa, parece que todos os esforços contribuíram para levar adiante discussões acaloradas sobre a função da arte e, respectivamente, do artista. A partir deste marco histórico, a imagem, que até então buscava os meios técnicos de captação, revelação e fixação em suportes sensíveis, não poupou intensivas ações para, mais tarde, se elevar à categoria de arte. Se olharmos retroativamente para esse período, vamos verificar um expressivo desenvolvimento dessa linguagem visual - de fixa a movimento - através do cinema, da televisão e do vídeo, o que mais tarde vai contribuir acentuadamente para um dos maiores saltos do século $X X$, a introdução de equipamentos digitais, de alta tecnologia, nas artes visuais.

Como elucida Santaella (2007), as linguagens transformaram-se de fixas a líquidas e escorrem sem que haja quaisquer hierarquias de espaço e tempo. Nesse sentido, não é de se estranhar o entrelaçamento dessa ocorrência nas artes visuais e a comunicação cada vez mais estreita entre as artes e toda essa nova concepção de mundo fragmentado. Enão é à toa que a enunciação da morte da pintura e da arte tenha sido, de certa forma, constante, durante todo o século XX. Junto às vanguardas modernistas, outras práticas visuais, inquietas, representavam um mundo dividido entre o "progresso" industrial, a ciência e as guerras, onde a arte se apresenta como um fruto desse contexto. Assim, quando falamos de períodos, como modernidade, contemporaneidade etc., devemos antes de tudo entender 
como a arte se move em um mundo constantemente em transformação, como esse, o que traz alguns questionamentos, sendo o principal deles: seu lugar nesse cenário.

Antes de avançarmos, porém, creio que, inicialmente, seja oportuno descrever sucintamente como se deu esse desenvolvimento, dando algum destaque aos antecedentes, pois se, por um lado, a imagem passou a habitar quaisquer tipos de espaços, contribuindo para uma sociedade global, onde a comunicação pode ser feita em tempo real, e sem fronteiras, em quase todos os cantos do planeta, por outro lado, há de se destacar que esse processo tecnológico não interrompe a atração dos artistas pela matéria e certos elementos, carregados de significados simples - o artesanal, o fazer, a presença da mão, o gesto, o homem e seu entorno -, onde o rural e o urbano se encontram. Vejamos como Roland Barthes (1979, p. 11), aborda esse assunto:

Os materiais são a matéria-prima, como para os alquimistas. A matéria-prima é o que existe anteriormente à divisão operada pelo sentido: um paradoxo enorme, porque, na ordem humana, nada chega ao homem que não seja imediatamente acompanhado de um sentido, o sentido que os outros homens the deram, e assim sucessivamente, em um infinito regresso. (tradução nossa)

Tendo a matéria como fio condutor, esta pesquisa se desenvolveu no âmbito desse entendimento. Partimos do princípio de que esse termo abrange todos os possíveis suportes sensíveis da concretização da ideia do artista, visto que as artes visuais dão forma a sentimentos e ideias. A palavra forma neste contexto significa "possibilitar", um meio para se "apresentar", que vai desde os materiais considerados "artísticos", passando por quaisquer outros elementos, objetos construídos artesanalmente ou apropriados à imagem, variando em suas características, que se entrelaçam a conceitos e estratégias, como apropriação, auto e/ou biografia do artista, desconstrução, desmaterialização, feminismo, hibridização, multiculturalis- 
mo, pluralismo etc., deixando sempre o registro do pensamento humano de uma época e de sua cultura identitária.

Assim, para entender melhor esse processo, foi necessário aprofundar conhecimentos na área da semiótica. Ao iniciarmos este estudo, logo verificamos a impossibilidade de desmembrar as ciências que fazem parte da arquitetura filosófica de Charles Sanders Peirce. Impossível também não se encantar com as suas sutilezas, da fenomenologia ao pragmatismo, passando pela estética, a ética, a lógica ou semiótica e a metafísica. Todavia, era necessário aplicar estas teorias ao nosso objeto de pesquisa. Mais uma vez entendemos que, não sendo a semiótica um método, nem as outras ciências mencionadas, essa interação (substituindo a palavra aplicar) teria de ser estabelecida através da essência do pensamento peirciano, que, não obstante ser filosófico, é, sobretudo, lógico.

Um dos elementos propulsores dessa interação deu-se de forma espontânea e progressiva, ou seja, ao passo em que se avançava no conhecimento da filosofia peirciana como um todo, o entendimento sobre a matéria, como parte da obra em si, foi se desfazendo. Logo a separação entre materiais, espaço, tempo, representação, real etc. descortinou-se como um processo semiótico, próprio do conceito peirciano de signo, como algo que cresce, gera novos signos, novos conhecimentos, e rompe com limites e dicotomias, tais como corpo versus mente. Ao pensar em qualquer parte constituinte da obra, todos os componentes de sua estrutura, desde os primeiros insights ao objeto finalizado, são indissociáveis.

Portanto, o caráter fundamental desta pesquisa relaciona-se ao encontro com a filosofia de Charles Sanders Peirce, durante o processo de investigação, indo muito mais além de um simples entendimento dos signos. Esta perspectiva nos oferece uma nova visão de mundo, das coisas ao nosso redor, do nosso comportamento frente ao outro, através de conceitos contemporâneos hoje aplicados em todas as áreas do conhecimento humano. Sendo um pensamento lógico, sem psicologismos nem subjetividade, podemos entender a arte a partir de suas próprias características, ou seja, a partir da classificação de um signo icônico, daquilo que é primo, livre, e que retorna sempre a si mesmo. 
Além da semiótica, o conceito peirciano de estética, como sendo o que é admirável, também afasta as discussões subjetivas sobre o que é e o que não é belo. Ao sabor dessas teorias, podemos ver a arte como um jogo semiótico e estético, um ir e vir, uma necessidade de conhecer o que nos aparece, e a flexibilidade de pensar, que desperta um encantamento, pela possibilidade de entender o processo de crescimento do signo. E por meio de seu conceito de hábito, Peirce nos leva a reconhecer um dos mais difíceis e ao mesmo tempo o mais nobre de todos: o hábito estético.

Segundo Santaella (2000a, p. 189), na metafísica de Peirce:

Ele viria a ligar a razão com o agapismo, a lei do amor evolutivo. O amor como o sentimento que dá ocasião para a razão se corporificar. É assim que um cientista se apaixona por uma idéia, uma tenra idéia, ainda sem força, que ele passa a cultivar, a cuidar dela como cuidamos de flores, sem nenhuma outra expectativa a não ser a de que elas nos respondam com vida.

A partir desse encontro com a filosofia de Peirce, percorremos os índices de contemporaneidade nas artes visuais com um olhar mais aguçado, com paradas substanciais, e o que antes era apenas uma questão de matéria, tornou-se espaço, tempo, corpo, natureza; nós e ao mesmo tempo o outro em nós. A cidade, os lugares, nada se exclui, tudo se constitui em um processo contínuo de multiplicação.

Essa visão nos levou a reflexões sobre o lugar da arte na contemporaneidade, e novas fontes emergiram ao longo desse processo. Nesse percurso, em busca de índices de contemporaneidade, identificamos a representação como um dos principais conceitos da arte: o próprio signo.

A partir de então, foi se delineando um panorama que se inicia com a crise da representação na pintura, no final do século XIX, o que coincide com a paisagem (landscape), passando, posteriormente, para outros "campos" epistemológicos, como espaços sígnicos ampliando-se no seu sentido epistemológico, ontológico, teórico, formal, estético e poético. 
Nos meandros desse trajeto, vislumbramos o corpus investigativo conceitual, o que nos fez perseguir o caminho apontado pela bibliografia pesquisada. Com o objetivo de verificar os diversos meios mais representativos das práticas visuais, percorremos os conceitos e teorias através de obras de artistas que marcaram essa época, e que, coincidentemente, apontavam para o tema natureza, paisagem. Quanto às questões sobre o lugar da arte, do final do século XIX até o início deste milênio, deparamonos com espaços labirínticos e sígnicos, os quais foram divididos em três momentos (paradigmáticos), a saber:

1. A crise da representação (final do século XIX), provocada pelo advento da fotografia; o Abstracionismo e as vanguardas modernistas;

2. A desmaterialização do objeto arte (final da década de 1960), mais especificamente a desconstrução da representação;

3. E por último, o período pluralista (final do século $X X$ até a nossa atualidade) com o retorno da pintura e das técnicas ditas tradicionais (escultura, desenho, fotografia), o que denominamos de rememoração.

Através desses momentos, foi possível delinear um contexto que estreia com a crise da representação, ilustrada nas últimas pinturas de Vincent van Gogh - Campos de trigo com corvos; a desconstrução do objeto arte, a partir do final dos anos 1960, exemplificada na obra de Agnes Denes Campos de Trigo - uma confrontação, pela qual é possível refletir sobre a representação dos Campos de trigo com corvos de Van Gogh e um campo de trigo "real"; e, por último, concluímos a pesquisa dando um destaque especial à homenagem visual que o artista alemão Anselm Kiefer presta a Vincent van Gogh, através de Campos de Girassóis, o que denominamos de rememoração.

Um olhar retroativo aos principais índices que marcaram a virada do século $X I X$ para o século $X X$, depois de mais de um século em busca de materiais e suportes diversos para expressar as ideias dos artistas, o século XXI surge como um período sem crise. Um período, denominado por Danto (1998), de pós-histórico ou pluralista, ou seja, um período em 
que o artista "pode fazer tudo" - pintura, escultura, desenho, gravura e fotografia - com seus meios e materiais tradicionais, juntamente a quaisquer práticas visuais.

E a natureza? Foi através de Peirce que chegamos à filosofia da natureza, de Schelling (2001a), ao conceito de admirável, que remonta aos pensadores pré-socráticos, e pode ser notadamente visto a partir dos anos 1960, na Earth Art, até os dias atuais. Mas esse retorno é o que Andrew Benjamin (1991), denomina de lógica do “again and anew”, e, para melhor explicarmos esse termo, dedicamos um espaço para defini-lo melhor, visto que ele nos levou ao encontro do termo "rememoração".

De acordo com Donald Kuspit (1993, p. 143), se a arte tentou imitar a natureza, depois de mais de um século, a natureza tornou-se um efeito artístico, uma ficção alcançada apenas através da manipulação de certo gênero de representação. $O$ natural não é mais algo que nos é dado incondicionalmente, como ponto de partida para informar quaisquer abstrações dele, mas, ao contrário, um fim para o qual alguém tem que regressar, sem a certeza de que será possível alcançá-lo. A natureza não é mais um critério autenticador da arte, mas um efeito desejado e inesperado, e talvez a única esperança para uma autoinovação num mundo onde o ser tornou-se abstrato e dispensável. Essa dimensão define as novas maneiras de ver e conceber um mundo até então representado como se fosse o real.

Devido à complexidade da arte e da sua construção, que possui interfaces com diversas áreas do conhecimento, seria impossível abordar todos os aspectos que envolvem esse processo. Pelo fato de não ser historiadora nem crítica de arte, mas pesquisadora dos meios pelos quais a arte contemporânea vem sendo construída, a história e a teoria da arte, bem como a filosofia e a estética são estudadas com propósitos específicos.

Cabe, portanto, ressaltar que as informações contidas neste livro não possuem nenhum intento de aprofundamento vertical das áreas acima mencionadas, mas, sobretudo, realizar um estudo, em alicerces transdisciplinares, e cujo eixo central está na semiótica da natureza da arte, ou seja: como as ideias dos artistas são (i)materializadas. 
Dado o argumento, espero que este livro possa contribuir de uma forma efetiva para reflexões sobre a arte, reflexões que permitam caminhar pela história da humanidade, sempre e cada vez com um novo olhar, ou como a própria etimologia da palavra filosofia na Grécia antiga nos indica: por amor ao saber. 


\section{UMA REFLEXÃO SOBRE A FILOSOFIA DE C. S. PEIRCE}

O real é aquilo que não é o que eventualmente dele pensamos, mas que permanece não afetado pelo que dele possamos pensar.

Charles S. Pierce, Collected Papers' $(8.12)^{2}$

Charles Sanders Peirce (1839-1914), cientista, matemático, historiador, filósofo e lógico, graduou-se com louvor pela Universidade de Harvard em

1 Collected Papers são manuscritos de estudos peircianos, ao todo somam 90 mil, que se encontram sob os cuidados do Departamento de Filosofia da Universidade de Harvard. Esta universidade publicou, em 1931-35 e 1958, os seguintes volumes: I - Princípios da Filosofia; II - Elementos de Lógica; III - Lógica Exata; IV - A mais simples Matemática; V - Pragmatismo e Pragmaticismo; VI Ciência Metafísica; VII - Ciência e Filosofia; e VIII - Comentários, Correspondência e Bibliografia. Disponível em: 〈http://www.hup.harvard.edu/catalog/PEICOA.html〉. Acesso em: 2007.

2 Usaremos a referência CP para indicar Collected Papers de Charles Sanders Peirce, por exemplo CP 3.362, o primeiro número corresponde ao volume e os demais ao parágrafo. 
química, além de ter dado contribuições influentes nos campos da geodésia, biologia, psicologia, matemática, filosofia etc. Peirce fazia parte do grupo de intelectuais e filósofos de relevância desse período, dentre eles: William James, Henry James, John Dewey, Gottlob Frege, Bertrand Russell etc.

Santaella ressalta em vários dos seus livros a grandiosa obra de Peirce. Primeiramente, em $O$ que é semiótica, essa autora o considera um "Leonardo das ciências modernas" (SANTAELLA, 1983, p. 19); em Matrizes da linguagem e do pensamento, sonora, visual, verbal, observa que "Peirce deixou nada menos do que 12 mil páginas publicadas e 90 mil páginas de manuscritos inéditos. Os manuscritos foram depositados na Universidade de Harvard [...]". (SANTAELLA, 2001, p. 6) Apenas vinte anos mais tarde, na década de 1930, surgiria a primeira publicação de textos coligidos nos seis volumes dos Collected Papers, editados por Hartshorne e Weiss. Infelizmente, grande parte dos textos aí reunidos restringiu-se a escritos que Peirce já publicara em vida. Santaella (2000a, p. 111) reafirma que: "A obra de Peirce é oceânica, de uma imensidão tamanha que seus limites se perdem de vista [...]”. Do mesmo modo, Ivo lbri (1992, p. xiii), compara a obra de Peirce "[...] em volume à de Leibniz [...]".

Desse modo, a análise que ora apresentamos visa introduzir sucintamente alguns dos principais conceitos da filosofia peirciana, os quais devem ser entendidos como um apêndice complementar ao assunto desenvolvido neste livro. E como Peirce não teve a oportunidade de documentar sua valiosa obra, as informações a que tivemos acesso devem-se, portanto, ao grupo de schollars que vêm se dedicando à organização, pesquisa e tradução dos manuscritos deixados por esse grande pensador, mais especificamente por Lucia Santaella, Ivo lbri e Winfried Nöth.

A partir da diversidade existente, podemos, portanto, dizer que Peirce construiu um trabalho labiríntico, no qual o pesquisador tem que se deixar levar pelos meandros do material para decifrar onde começa e termina cada parte. Por conseguinte, qualquer afirmação ou interpretação que fuja à devida concepção dos seus conceitos pode se tornar um enorme equívoco. Desse modo, vamos buscar oferecer apenas concisas e precisas 
informações, sem perder de vista o nosso foco principal, com o cuidado e o devido respeito que sua obra requer.

Em Estética: de Platão a Peirce, Santaella (2000a, p. 113) apresenta o quadro desenhado por Peirce que, "de acordo com sua concepção pragmatista das ciências, o significado de cada ciência só aparece na rede de inter-relações que ela entretém com as demais".

\section{FILOSOFIA}

1. Fenomenologia

2. Ciências Normativas

\subsection{Estética}

2.2. Ética

\subsection{Lógica ou Semiótica}

\subsubsection{Gramática Pura}

\subsubsection{Lógica Crítica}

\subsubsection{Metodêutica}

3. Metafísica.

A partir desse diagrama, podemos verificar que a primeira ciência que aparece na sua filosofia é a fenomenologia, seguida das ciências normativas. Assim sendo, a estética, a ética e a lógica ou semiótica são concebidas como ciências no campo da filosofia. De acordo com Santaella (2000a, p. 113-114):

Para Peirce, a filosofia em geral tem por tarefa descobrir o que é verdadeiro, limitando-se, porém, à verdade que pode ser inferida da experiência comum que está aberta a todo ser humano a qualquer tempo e hora. A primeira e talvez mais difícil tarefa que a filosofia tem de enfrentar é a de dar à luz às categorias mais universais da experiência. Essa tarefa é da alçada da fenomenologia, uma quase ciência que tem por função fornecer o fundamento observacional para o restante das disciplinas filosóficas. As ciências normativas são assim chamadas porque estão voltadas para a compreensão 
dos fins, das normas e ideais que regem o sentimento, a conduta e o pensamento humanos. Elas não estudam os fenômenos tal como aparecem, quer dizer, na sua aparência, pois essa é a função da fenomenologia, mas os estudam na medida em que podemos agir sobre eles e eles sobre nós. Elas estão voltadas, assim, para o modo geral para o qual o ser humano, se for agir deliberadamente e sob autocontrole, deve responder aos apelos da experiência. Usando os princípios da lógica, a metafísica investiga o que é real, na medida em que esse real pode ser averiguado na experiência comum. É dela a tarefa de fazer a mediação entre a fenomenologia e as ciências normativas, desenvolvendo uma teoria da realidade.

\section{Fenomenologia}

Como podemos observar, na citação acima, a fenomenologia está em primeiro lugar, dada a importância que essa ciência desempenha. A estética, Peirce associa às ciências normativas, que "descobrem leis que relacionam os fins aos sentimentos [...] à ação, no caso da ética, e ao pensamento, na lógica”. (SANTAELLA, 2000a, p. 141-142) Já o papel da fenomenologia é proporcionar o fundamento de observação à lógica e à metafísica, posto que elas estão relacionadas à experiência com o que se exterioriza, ou seja, como o ser humano vai reagir diante do real, o que, por sua vez, se dá por meio da mediação de signos. À percepção interessa tudo aquilo que está no aqui e agora, nos diz Peirce, mas "só percebemos aquilo que estamos equipados para interpretar”. (SANTAELLA, 2000a, p. 52) A definição do termo "perceber" e todos os demais conceitos da obra de Peirce possuem uma ordem lógica e não podem ser tratados independentemente de outros conceitos. Perceber algo não requer apenas ver, mas estar diante de algo que se apresenta como um todo, que deve ser apreendido através de todos os sentidos, tanto do sensorial como do cognitivo. Assim é que a filosofia peirciana entende a realidade fenomenologicamente, ou seja, o real é tudo aquilo que se exterioriza, que aparece e se coloca à 
experiência, por meio de três categorias denominadas de primeiridade, segundidade e terceiridade.

No artigo Sobre uma nova lista de categorias (1867), Peirce apresenta suas três categorias universais, incluindo tudo que nos afeta, seja fisicamente, seja emocionalmente e intelectualmente, ou o que vemos, percebemos e apreendemos. Ao dividir todas essas propriedades em gradações, elas obedecem a um sistema composto de três elementos formais de toda e qualquer experiência, categorias denominadas de qualidade, relação e representação. Mais tarde, Peirce substituiu o termo "relação" por "reação", e o termo "representação" por "mediação", o que veio a se tornar cientificamente em primeiridade, segundidade e terceiridade. Santaella (1983), descreve as categorias de Peirce com uma série de exemplos que ilustram os conceitos desse filósofo. Vejamos então, nas considerações que se seguem, os principais conceitos à luz dessa autora.

Primeiridade é a qualidade da consciência imediata; é uma impressão (sentimento) in totum, invisível, não analisável, frágil. Tudo que está imediatamente presente à consciência de alguém é tudo aquilo que está na sua mente no instante presente. O sentimento como qualidade é, portanto, aquilo que dá sabor, tom, matiz à nossa consciência imediata, aquilo que se oculta ao nosso pensamento. A qualidade da consciência, na sua imediaticidade, é tão tenra que mal podemos tocá-la sem estragá-la. A secundidade é a arena da existência cotidiana, estamos continuamente esbarrando em fatos que nos são externos, tropeçando em obstáculos, coisas reais, factivas, que não cedem ao sabor de nossas fantasias. $O$ simples fato de estarmos vivos, existindo, significa, a todo momento, que estamos reagindo em relação ao mundo. Existir é sentir a ação de fatos externos resistindo à nossa vontade, é estar numa relação, tomar um lugar na infinita miríade das determinações do universo, resistir e reagir, ocupar um tempo e espaços particulares. Onde quer que haja um fenômeno, há uma qualidade, isto é, sua primeiridade. Mas a qualidade é apenas uma parte do fenômeno, visto que, para existir, a qualidade tem que estar encarnada numa matéria. O fato de existir está nessa corporificação material. A terceiridade, a última das categorias, é a camada de inteligibilidade, ou pensamento em signos, 
através da qual representamos e interpretamos o mundo. Por exemplo: "O azul, simples e positivo azul, é o primeiro. $O$ céu, como lugar e tempo, aqui e agora, onde se encarna o azul é um segundo. A síntese intelectual e laboração cognitiva - o azul no céu, ou o azul do céu - é um terceiro". (SANTAELLA, 1983, p. 51)

Por sua vez, Ivo Ibri (1992, p. 5), com o intuito de reforçar o pensamento de Peirce para inserir as três categorias que servem de apoio à fenomenologia, nos informa que:

As faculdades que devemos nos esforçar por reunir para este trabalho são três. A primeira e a principal é aquela rara faculdade, a faculdade de ver o que está diante dos nossos olhos, tal como se apresenta sem qualquer interpretação.[...] Esta é a faculdade do artista que vê, por exemplo, as cores aparentes da natureza como elas se apresentam.

A concepção epistemológica peirciana das três categorias tem um destaque especial na primeiridade, na contemplação, onde $\mathrm{o}$ ato de perceber requer um tipo de integração com o que está sendo visto de tal forma que, conforme Peirce:

Ao contemplar uma pintura, há um momento em que perdemos a consciência do fato de que ela não é uma coisa. A distinção do real e da cópia desaparece e por alguns momentos é puro sonho; não é qualquer existência particular e ainda não é existência geral. Nesse momento, estamos contemplando um ícone. (CP 3.362)

Considerando essas três categorias, Ibri (1992, p. 6) as resume como "ver, atentar para e generalizar, despindo a observação de recursos essenciais de cunho mediativo". A fenomenologia, muito embora apareça como a primeira ciência no diagrama de Peirce, corresponde à categoria da segundidade, visto que: 
No fenômeno, surge a idéia de outro, de alter, de alteridade; com ela aparece a idéia de negação, a partir da idéia elementar de que as coisas não são o que queremos que sejam, tampouco são estatuídas pelas nossas concepções. [...] Esta experiência de reação envolvendo negação é adjetivada de bruta por Peirce, pois traz de modo direto a força de um segundo, caracterizado por ser esta coisa e não aquela. A experiência direta com isto que não é aquilo se dá num recorte do espaço e do tempo, traçando os contornos deste objeto, que é forçado e reage contra a consciência como algo individual. (IBRI, 1992, p. 7)

Durante o processo de experiência que inclui as categorias, Santaella (2000a, p. 116) explica que "a fenomenologia peirciana realiza a proeza de integrar o geral no particular, o concreto no abstrato, dentro de uma lógica ternária que não busca se livrar do fato bruto, de um lado, além de incluir o acaso, do outro". Já a categoria da terceiridade foi concebida por Peirce para colocar a experiência fenomenológica em processo de continuidade, ad infinitum, do continuum. É nessa categoria que, conforme nos informa Peirce (apud IBRI, 1992, p. 14), existe a "consciência sintética, ligação com o tempo, sentido de aprendizagem. [...] Da natureza do conceito e do pensamento, o elemento cognitivo deve ser geral e ter o estatuto de representação". A partir desse raciocínio "onde quer que a Mediação seja predominante e que encontre sua plenitude na Representação, Terceiridade, como eu uso o termo, é apenas um sinônimo para Representação" (IBRI, 1992, p.15), sendo, portanto, todos esses conceitos (mediação, pensamento, cognição etc.) fenomênicos.

Santaella (2000b, p. 50-51) discorre sobre a tríade perceptiva, da seguinte maneira:

Peirce chega a uma posição dialética ou esquema triádico (como não poderia deixar de ser), que determina três e não apenas dois ingredientes de toda e qualquer percepção: o percepto, o percipuum e o julgamento perceptivo. [...] Perceber é perceber algo externo a nós. Mas não podemos dizer nada sobre aquilo que é externo, a 
não ser pela mediação de um julgamento perceptivo. Aquilo que está fora, Peirce denomina percepto, aquilo que nos diz o que nós percebemos é o julgamento perceptivo.

Por percepto, Santaella (2000b, p. 53) define tudo aquilo que se apresenta, e que percebemos, e isso nos chega apreendido num ato de percepção, é algo que está fora de nós e de nosso controle; o percepto tem realidade própria no mundo que está fora de nossa consciência, e que é apreendido pela consciência no ato perceptivo. O percipuum (objeto imediato da percepção) faz o percepto (objeto dinâmico da percepção) se conformar a uma determinada configuração. Por último, o juízo perceptivo é o julgamento de percepção ou juízo perceptivo que vai nos dizer o que estamos interpretando; é este último "que nos diz algo sobre o que é percebido".

\section{Estética}

Como nos diz Santaella (2000a, p. 188-189), "[...] Peirce foi buscar no kalós grego, algo que toda alma vagamente deseja e muito mais vagamente percebe - um ideal admirável, tendo a única forma de excelência que uma idéia desse tipo pode ter: a excelência estética".

A noção de estética vem da Grécia, quando esse termo estava associado à relação do homem com a natureza. Somente a partir de meados do século XVIII, aproximadamente nos anos de 1750, a estética aparece como ciência através de Alexander Gottlieb Baumgarten. Diante do exposto, não deve causar nenhum estranhamento o significado atribuído por Peirce a esse termo - admirabilidade -, ideal, como vamos verificar em Santaella (2000a, p. 13):

Peirce não deixou nenhum tratado sobre estética. Mas, não obstante tenha, quando jovem, estudado, com muito cuidado e paixão, as cartas Sobre a Educação Estética da Humanidade de Johann 
Christoph Friedrich von Schiller (1759 - 1805), e fosse um grande conhecedor da obra de Kant, não obstante tivesse um grande interesse pelas artes. [...] Mas, sobretudo a partir de 1900, a Estética passou a ocupar um lugar proeminente na arquitetura filosófica de Peirce a um tal ponto que, sem a compreensão aprofundada do papel fundamental por ela desempenhado como alicerce da ética e, por extensão, da lógica ou semiótica, não é possível entender o seu segundo pragmatismo.

Sendo a primeira das ciências normativas, Santaella (2000a, p. 114) sublinha que na estética peirciana "o ideal estético é nutrido pelo cultivo de hábitos de sentimentos. Sendo as obras de arte aquelas coisas que encarnam qualidades de sentimento, os hábitos de sentimento só podem ser cultivados através da exposição de nossa sensibilidade às obras de arte".

Quando Peirce afirma ser a estética, juntamente com a ética e a lógica, responsáveis pela busca de um ideal admirável - o que ele queria dizer com isso? Vejamos o que Santaella (2000a, p. 127) nos descreve:

O admirável por si só pode ser uma natureza estética. Só qualidades, reino da Estética, são admiráveis sem exigir explicações. O estado de coisas admiráveis não pode, assim, ser determinado aporiticamente; É uma meta ou ideal que descobrimos porque nos sentimos atraídos por ele como tal, e nele ficamos emanados, empenhando-nos na sua realização concreta.

Tais considerações nos levam a entender que a estética é uma ciência voltada para o conhecimento e o crescimento; portanto, as artes devem ser compreendidas na filosofia peirciana dessa maneira. Tanto é assim, que "as obras de arte não são apenas ambíguas encarnações de qualidades e sentimentos, mas formas de sabedoria, de um tipo em que convida a razão a se integrar ludicamente ao sentir”. (SANTAELLA, 2000a, p. 150) São elas que enchem de prazer estético tanto o artista, poetas e escritores, como aos que as apreendem com todos os seus sentidos. 
Todavia, de acordo com Santaella (2000a, p. 182), nada pode haver de mais vago, incerto, indeterminado e impreciso do que qualidades de sentimento. A obra de arte seria aquela instância semiótica muito rara, capaz de realizar a proeza de dar corpo e forma ao incerto e indeterminado.

De acordo com esta autora, para Peirce, "nenhum ícone representa nada além de forma, nenhuma forma pura é representada por nada a não ser um ícone [...] pois, em precisão de discurso, ícones nada podem representar além de formas e sentimentos, mas, ao mesmo tempo [...]", o ícone "[...] é, no entanto, o mais revelador, porque na sua ambigüidade é capaz de flagrar o cerne da realidade, lá onde o ambíguo e o indeterminado fazem sua morada”. (SANTAELLA, 2000a, p. 184-185)

Santaella (2000a, p. 180-181) nos informa que Jorge Luis Borges apresentou passagens admiráveis, observando que:

A música, os estados de felicidade, a mitologia, as cores trabalhadas pelo tempo, certos crepúsculos e certos lugares querem nos dizer algo, ou disseram algo que não deveríamos ter perdido, ou então para dizer algo, esta iminência de revelação, que não se produz, é, talvez, o fato estético. Foi isso o que sempre ensinei, limitando-me ao fato estético, que não pode ser coisa de definição. $\bigcirc$ fato estético é algo tão evidente, imediato e indefinível quanto o amor, o gosto da fruta, a água.

O prazer estético à luz desses estudiosos tem um significado especial; é um sentimento que possui um continuum e visa atingir um ideal: gerar hábitos, comunhão de pensamento, aprendizado e conhecimento, algo que não pode ser aplicado indeterminadamente a qualquer tipo de arte. Santaella (2000a, p. 34) mais uma vez nos diz que em um "lindo ensaio sobre 'Beleza e Imitação', Jacques Maritain compôs o belo de Santo Tomás numa orquestração poética que merece ser ouvida”[...], pois:

O belo é que dá alegria, não qualquer alegria, mas alegria no conhecimento; não na alegria peculiar do ato de conhecimento, mas uma 
alegria super abundante, extrapolada. Se algo exalta e delicia a alma pelo simples fato de ser achado na intuição da alma, é bom de ser apreendido, é belo. A beleza é essencialmente o objeto de inteligência, pois o que conhece, no pleno sentido da palavra, é a mente. Apenas ela aberta para a infinitude do ser. [...] $\bigcirc$ belo se relaciona à visão e audição entre todos os sentidos porque esses dois são máxima cognoscitiva. [...] $\bigcirc$ belo conatural ao homem é aquele que vem dedicar à alma através dos sentidos e suas intuições. Esse também é o belo particular de nossa arte que trabalha sobre uma matéria sensivel para o paraíso terrestre, porque restaura, por um breve momento, a paz simultânea e a delícia da mente e dos sentidos.

\section{Ética}

A ética determina a lógica através da análise dos fins aos quais esses meios se dirigem; a estética determina a ética ao definir qual é a natureza de um fim que seja em si mesmo admirável e desejável em quaisquer circunstâncias, independentemente de qualquer outra espécie de consideração. Em Peirce (2005), a ética e a lógica são subsidiárias da estética, visto que a ética recebe seus princípios básicos da estética. Assim, a ação deve ser baseada em atos admiráveis (e, portanto, controlados por esse princípio), remetendo mais uma vez ao summum bonum.

Nas palavras de Peirce (CP 2.199), é possível ter uma noção mais adequada dessa associação entre a ética, a estética e a lógica. Vejamos:

[...] para apresentar a questão da estética em sua pureza, devemos eliminar dela não apenas todas as considerações acerca de esforço, mas todas as considerações sobre ação e reação, incluindo toda consideração acerca da nossa recepção do prazer, tudo, em síntese, que pertença à oposição entre ego e não-ego. Não temos em nossa língua uma palavra com a generalidade requisitada. O grego kalós, o francês beau apenas se aproximam, sem atingi-la 
exatamente na cabeça. "Fine" seria uma pobre substituta. Belo é mau, porque um modo de ser kalós depende essencialmente da qualidade ser não-bela. Talvez, contudo, a frase "o belo do não belo" não fosse ofensiva. Mas "beleza" é muito superficial ainda. Usando-se kalós, a questão da estética é: Qual é aquela qualidade que, na sua presença imediata, é kalós? Desta questão, a ética deve depender, assim como a lógica deve depender da ética. A estética, portanto, embora eu a tenha negligenciado terrivelmente, aparece possivelmente como a primeira propedêutica indispensável para a lógica, e a lógica da estética constitui uma parte distinta da ciência lógica que não deve ser omitida.

\section{Lógica ou Semiótica}

A semiótica concebida por Peirce, que tem sua origem durante o período correspondente ao final do século XIX e início do século XX, é considerada uma ciência dentro de uma obra filosófica arquitetônica, conforme ilustrado através do quadro elaborado por esse filósofo, já apresentado. Santaella (1983, p. 7) assinala que o termo "semiótica vem da raiz grega semeion, que quer dizer signo". Devido à sua constituição - e sendo por definição a ciência que estuda todos os tipos de signo -, a semiótica pode ser aplicada amplamente em estudos de várias áreas. Conforme a referida autora, "semiótica é a ciência que tem por objeto de investigação todas as linguagens possíveis, ou seja, que tem por objetivo o exame dos modos de constituição de todo e qualquer fenômeno de produção de significação e de sentido". (SANTAELLA, 1983, p. 13)

Vamos encontrar outras definições em Nöth (1995a, p. 19), que assegura que "a semiótica é a ciência dos signos e dos processos significativos (semiose) na natureza e na cultura”, o que vem reforçar o nosso entendimento de que dentro dessa ampla possibilidade de abrangência, encontram-se as artes visuais, que, por serem uma linguagem não-verbal e também signo, podem ser analisadas através dessa ciência e dos seus meios de representação. 
Contudo, esse termo é mais recente do que suas primeiras aplicações, as quais estavam implicadas nos conceitos da filosofia da Grécia antiga. Ainda de acordo com Nöth (1995a, p. 19-20), “o médico grego Galeno de Pérgamo (139-199), por exemplo, referiu-se à diagnóstica como sendo a parte semiótica (semeiotikón méros) da medicina” [, e, assim como John Locke,] "postulou uma 'doutrina dos signos' com o nome de Semeiotiké”, [e, no século XVII, em 1764, Johann H. Lambert escreveu] "um tratado específico intitulado Semiotik”. No século XX, logo após os meados da década de 1960, o estudo desta ciência foi retomado por Thomas Sebeok. Portanto, de Saussure a Peirce, o signo é entendido por meio de diferentes definições.

Segundo Santaella e Nöth (1997, p. 24), "tanto Saussure quanto Hejelmslev fundaram a tradição do signo concebido a partir de um paradigma lingüístico" e suas concepções se caracterizavam como uma semiótica diádica, do mesmo modo como se caracterizam os semioticistas da Escola de Moscou e Tartu. Somente mais tarde, na década de 1970, em decorrência da tradução para o inglês das obras da escola de Moscou, Tartu e do Círculo de Bakhtin, foi que os estudos da semiótica "direcionaram-se para a cultura em geral”. (SANTAELLA e NÖTH, 1997, p. 79)

Não obstante a obra de Charles Peirce ter sido criada anteriormente a esses semioticistas já mencionados, só na década de 1970 é que a semiótica peirciana foi divulgada graças a Roman Jakobson, que mostrou a importância "da rica herança e do amplo domínio de pesquisa semiótica deixada por Charles Sanders Peirce [...] para o estudo dos mais diversos processos de signos". (SANTAELLA e NÖTH, 1997, p. 79) Continuando suas observações e concluindo com as informações sobre a parte histórica, esses autores ainda esclarecem que:

Assim como a comunicação, também os signos, isto é, a produção de trocas simbólicas sempre existiu e são fatores de constituição da própria condição humana. Por isso mesmo, a semiótica, mesmo que nem sempre com esse nome, enquanto reflexão sobre a linguagem e seus sentidos, teve suas origens já no mundo grego e atravessou, com características próprias de sua época, toda a história humana desde então. (SANTAELLA e NÖTH, 1997, p. 24) 
Ressaltamos que a tríade semiótica envolve dois tipos de relações: determinação e representação. As relações de representação dependem das relações de determinação, pelo fato de a representação somente poder ocorrer através de uma determinação provocada pela mediação. Assim, a semiótica ocupa-se do estudo do processo de significação, ou seja, pelos meios da representação, de uma forma ampla e geral, não obstante, neste livro, nosso eixo ser a representação nas artes visuais.

\section{Signo}

Muito embora diversos sejam os significados do signo, é preciso alguns esclarecimentos básicos sobre sua definição. Para Peirce (2005, p. 46), um "signo é aquilo que sob determinado aspecto ou de algum modo, representa alguma coisa para alguém". Desse ponto de vista, todo pensamento é signo, incluindo a natureza, todos os seres naturais, as ideias, os sentimentos, assim como o próprio homem. Para Santaella (2000b, p. 12):

Signo ou representamen é aquilo que, sob certo aspecto ou modo, representa algo para alguém. Dirige-se a alguém, isto é, cria, na mente dessa pessoa, um signo equivalente, ou talvez um signo mais desenvolvido. Ao signo assim criado denomino interpretante do primeiro signo. $\bigcirc$ signo representa alguma coisa, seu objeto. Representa esse objeto não em todos os seus aspectos, mas com referência a um tipo de idéia que eu, por vezes, denominei fundamento do representamen.

Na teoria dos signos, signo ou representamen é o primeiro que está em relação de representação para um segundo - o objeto -, para fins de sua significação em um terceiro, seu interpretante. A noção peirciana de signo consiste, portanto, nessa relação triádica: signo-objeto-interpretante, uma relação também denominada de semiose que, "pode ser conside- 
rada como sinônimo de inteligência, continuidade, crescimento e vida”. (SANTAELLA e NÖTH, 2004, p. 157) Ora, se um signo tem a intenção de representar um objeto (ou partes dele) através da mediação de um signo entre um objeto dinâmico e um interpretante final, nas artes visuais podemos ilustrar essas definições a partir de qualidades, próprias da categoria da primeiridade, isto é, sensação provocada pelas cores, pelas formas, textura etc. Nesse caso, o signo da pintura, em princípio, são essas qualidades. Outro exemplo nos é dado, por Santaella e Nöth (2004, p. 198), sobre o conceito de representação:

A semiótica peirciana é uma teoria complexa e multifacetada da representação. Esta apresenta variantes como apresentação, a quaserepresentação até o limite da presentificação. [...] Os conceitos de representação de mediação estão carregados de implicações filosóficas, [...] por representar o objeto é que o signo pode cumprir a função mediadora.

Desde o início de suas pesquisas sobre o signo, onde se debruçou intensamente por toda a sua vida, Peirce concebeu três tricotomias, a saber: a primeira, relacionada à natureza material do signo, ou seja, uma relação de pura qualidade, de sensações, de singularidade, de liberdade, na qual se encontra a arte, um signo que encerra qualidades. Nessa relação não há um segundo, uma alteridade como efeito bruto. Porém, há de se considerar que existe um diferente tipo de objeto, que pode ser qualquer coisa, como sentimentos, emoções, ideias do artista etc. Então, devemos entender que esse objeto está representado no quali-signo, ou seja, o representamen, como quali-signo é o ponto principal da semiose artística. Nesse aspecto, um signo pode ser um quali-signo, um sin-signo ou um legisigno. Na segunda, existe uma relação do signo com seu objeto, podendo o signo ser ícone, índice ou símbolo, e por último, a terceira, que relaciona o signo ao seu interpretante, em cuja relação o signo pode ser um rema, um dicente ou um argumento. 
Face às considerações enunciadas, as divisões do signo, portanto, se estabelecem como "as mais conhecidas das tríades formuladas por Peirce" e descritas por Santaella (2000b, p. 92), a saber:

Ao signo em si mesmo (quali-signo, sin-signo, legi-signo), à relação do signo com o objeto dinâmico (ícone, índice, símbolo), e à relação do signo com seu interpretante (rema, dicente, argumento). [...] Cada uma dessas divisões foi então re-subdividida de acordo com as variações próprias das categorias de primeiridade, secundidade e terceiridade. Os signos em si mesmos podem ser: 1.1 qualidades; 1.2 fatos; e 1.3 ter a natureza de leis ou hábitos. Os signos podem estar conectados com seus objetos em virtude de: 2.1 uma similaridade; 2.2 de uma conexão de fato, não cognitiva; e 2.3 em virtude de hábitos (de uso). Finalmente, para seus interpretantes, os signos podem representar seus objetos como: 3.1 sendo qualidades, apresentandose ao interpretante como mera hipótese ou rema; 3.2 sendo fatos, apresentando-se ao interpretante como dicentes; e 3.3 sendo leis, apresentando-se ao interpretante como argumentos. Dessas nove modalidades, Peirce extraiu as combinatórias possíveis.

Segundo Peirce, um ícone "é estritamente uma possibilidade envolvendo uma possibilidade, e assim, a possibilidade de ele ser representado como uma possibilidade é a possibilidade da possibilidade envolvida" (CP 2.31), e por ser "um signo cuja qualidade significante provém meramente da sua qualidade" (CP 2.92), ele inscreve-se na primeiridade. Em artes visuais, os exemplos mais comuns de hipoícones são pinturas e fotografias. Nöth (1995a, p. 80), explica que um ícone puro é um signo que serve "como signo pelo fato de ter uma qualidade que o faz significar". Em vista disso, o ícone puro pode apenas constituir "um fragmento de um signo mais completo". Por não alcançar a segunda categoria, o ícone não tem existência em relação ao seu objeto. $\mathrm{O}$ seu objeto é tudo aquilo que a ele é semelhante.

Embora a complexidade da obra de Peirce seja notória para seus pesquisadores, como já informamos anteriormente, Santaella (2000b, p. 5) sugere que devemos: 


\begin{abstract}
Aprender a olhar os signos de frente, tanto na finíssima película de sua superfície, quanto na visão em raio $X$, despidos dos subterfúgios ardilosos que o racionalismo exclusivista não cessa de procriar, poderemos imediatamente enxergar com nossos olhos renovados as eternas questões do real, da referência, do sujeito, do papel da representação e da interpretação. A obra de Peirce tem muito a nos ajudar.
\end{abstract}

Isto porque vivemos num mundo povoado cada vez mais por signos, a tal ponto que, ainda segundo essa autora, se Peirce tivesse vivido neste século, teria se surpreendido com os avanços semióticos, provocados pela própria característica de nossa era, do milênio digital das máquinas inteligentes.

\title{
Objeto
}

Santaella (2000b, p. 34-35) evidencia "a imensa complexidade da noção do objeto, ou melhor, a enorme gama de variações que essa noção pode recobrir", complementando:

Para abrirmos caminho no labirinto dessas variações, creio que cumpre reter, para começar, que o objeto é algo diverso do signo e que este "algo diverso" determina o signo, ou melhor: o signo representa o objeto, porque, de algum modo, é o próprio objeto que determina essa representação; porém aquilo que está representado no signo não corresponde ao todo do objeto, mas apenas a uma parte ou aspecto dele. Sempre sobram outras partes ou aspectos que o signo não pode preencher completamente.

Desse modo, podemos dizer que "o objeto é tudo que pode ser expresso por um signo, todavia, é em virtude da diversidade irredutível entre signo e objeto que Peirce introduz a noção de experiência colateral com aquilo que o signo denota, ou representa, ou se aplica, isto é, seu 
objeto". (SANTAELLA, 2000b, p. 35) Mas o que podemos entender por experiência colateral?

Experiência colateral é algo que está fora do signo, portanto fora do interpretante que o próprio signo determina. Na medida em que o interpretante é uma criatura gerada pelo próprio signo, essa criatura recebe do signo apenas o aspecto que ele carrega na sua correspondência com o objeto e não com todos os outros aspectos do objeto que o signo não pode recobrir. (SANTAELLA, 2000b, p. 36)

A experiência colateral, de acordo com Peirce (CP 8.181), significa que, para conhecer o objeto, é preciso uma experiência prévia desse objeto individual, pois "enquanto o signo denota o Objeto não precisa de especial inteligência ou Razão da parte de seu Intérprete. [...] para conhecer o Objeto, o que é preciso é a experiência prévia desse Objeto Individual". Com a divisão do objeto, em imediato e dinâmico, podemos dizer, segundo Santaella (2002, p. 34), que o objeto imediato denota um objeto dinâmico e, portanto,

[...] o melhor caminho para começar a análise da relação objetal é o do objeto imediato. Afinal, parece não haver outro modo de começar, visto que o objeto dinâmico só se faz presente, mediatamente, via objeto imediato, este interno ao signo.

A divisão dos objetos do signo em dinâmico e imediato mostra que, com o objeto dinâmico, Peirce (5.212) identificou aquilo que está fora da cadeia sígnica, aquilo que algumas vezes ele chamou de "real" ou "realidade", mas que pode ser também fictício. E diante da pergunta "em que medida esse objeto - que está fora - participa do processo sígnico?", Santaella (2000b, p. 46) lembra que, "de acordo com Peirce, o fato de o objeto dinâmico ser mediado pelo objeto imediato não o leva a perder o poder de exercer uma influência sobre o signo, uma vez que o signo só funciona como tal porque é determinado pelo objeto dinâmico". 


\section{Ícone, Índice e Símbolo}

O ícone é um signo cujas condições de significação prescindem da existência de seu objeto, isto é, o ícone pode significar quer seu objeto seja uma existência ou realidade. $\bigcirc$ ícone prescinde do objeto para significar. Toda hipótese é icônica. $\mathrm{O}$ índice é o signo que significa tão somente através de seu vínculo existencial com o seu objeto. Desta forma, é a existência do objeto que determina a possibilidade interpretante do índice. $\mathrm{O}$ índice não prescinde do objeto para significar. $\bigcirc$ símbolo representa através de uma lei geral (regras), convencional ou semiconvencional. $\bigcirc$ símbolo refere-se ao que possa concretizar a ideia ligada à palavra. Quanto à sua divisão vejamos, nos dois trechos a seguir, a definição de Peirce:

Os signos são divisíveis conforme três tricotomias; a primeira, conforme o signo em si mesmo for uma mera qualidade, um existente concreto ou uma lei geral; a segunda, conforme a relação do signo para com seu objeto consistir no fato de o signo ter algum caráter em si mesmo, ou manter alguma relação existencial com esse objeto ou em relação com um interpretante; a terceira, conforme seu interpretante, representá-lo como um signo de possibilidade ou como um signo de fato ou como um signo de razão. (PEIRCE, 2005, p. 51)

Uma progressão regular de um, dois, três pode ser observada nas três ordens de signos, Ícone, Índice e Símbolo. O Ícone não tem conexão dinâmica alguma com o objeto que representa; simplesmente acontece que suas qualidades se assemelham às do objeto e excitam sensações análogas na mente para a qual é uma semelhança. Mas, na verdade, não mantém conexão com elas. $\bigcirc$ Índice está fisicamente conectado com seu objeto; formam, ambos, um par orgânico, porém a mente interpretante nada tem a ver com essa conexão, exceto o fato de registrá-la, depois de ser estabelecida. S Símbolo está conectado ao seu objeto por força da idéia da mente-que-usa-o-símbolo, sem a qual essa conexão não existiria. (PEIRCE, 2005, p. 73) 


\section{Metafísica}

$\mathrm{Na}$ filosofia de Charles S. Peirce, a metafísica procura explicar como o mundo deve ser e como ele se apresenta compatível com as determinações da fenomenologia, sendo, portanto, a metafísica a ciência que estuda a natureza, suas leis, comportamento, regularidades, repetições, hábitos etc. De acordo com Ibri (1992, p. 123), as três categorias da metafísica correspondem também ao acaso (primeiridade), à existência (segundidade) e à lei (terceiridade):

A Metafísica iluminará a compreensão semiótica, e um dos pontos focais de luz emana do fato de que a forma do objeto se impõe à forma com um caráter explicitamente ontológico de morphé, cabe registrar, também, que tal caráter se perdeu ao longo da história.

$\mathrm{Na}$ filosofia peirciana, o acaso manifesta-se na forma de variedade, diversidade, mera possibilidade. Sua principal característica é a liberdade, a espontaneidade. A primeiridade metafísica é, portanto, o acaso entendido como princípio de liberdade presente na natureza, como uma propriedade que se manifesta no mundo na forma de assimetria. Uma vez que a primeira categoria ontológica diz respeito ao mero poder-ser, àquele estágio em que ainda não se manifestou a existência, mas apenas em potencialidade para vir-a-ser, então não podemos afirmar a existência de informação no âmbito da primeiridade. Se o problema da representação se encontra enfatizado por Peirce na sua teoria formal dos signos, os problemas da realidade e da verdade são abordados, respectivamente, no âmbito da sua fenomenologia, isto é, na teoria das categorias, e no âmbito da teoria pragmática dos signos.

\section{Pragmatismo e Semiose}

Segundo Santaella (2004a, p. 240), a primeira proposta do pragmatismo foi feita em 1878, particularmente nos ensaios Como tornar nossas idéias claras e A fixação das crenças, mas, apenas em 1898, as ideias de Peirce referentes a esse tema foram expostas, através de William James, durante palestra 
proferida na Universidade da Califórnia. Tal foi a repercussão, que Peirce retomou "sua análise anterior de crença em cujo núcleo estava inserida sua original concepção de hábito". A partir de então, Peirce também retoma "a teoria dos signos, especialmente dos interpretantes". (SANTAELLA, 2004a, p. 241) Santaella (2004a, p. 242) conclui, assim, que, para Peirce, "uma crença não nos coloca em ação prontamente, mas sim numa condição tal que deveremos agir de um certo modo quando a ocasião surgir".

Santaella (2000b, p. 75) observa que, segundo Savan (1976),

O efeito semiótico pleno de um signo, se o seu propósito ou intenção viesse a ser atingido, é o interpretante final daquele signo. Uma vez que esse propósito fornece a norma que influencia a sucessão dos interpretantes dinâmicos, ele também pode ser chamado de interpretante normal. E uma vez que a evolução de interpretantes dinâmicos sucessivos tende para o padrão estabelecido pelo interpretante final, seja este padrão, de fato, plena e exatamente satisfeito ou não, ele também pode ser chamado de interpretante destinado. A ação desse padrão, na medida em que ele afeta e influencia cada interpretante dinâmico real, é o que lhe dá vida e poder para se transformar em um hábito e numa crença.

Assim posto, por pragmatismo, entende-se a ação do homem frente a uma experiência fenomenológica, ou seja, a ação perante o alter, um segundo, o objeto, o real, e a maneira como ele reage, que necessita tanto a análise dos signos como dos interpretantes. Através desses estudos, Peirce, então, poderia investigar a conduta, e a partir de sua regularidade, a aquisição de hábito. Diferentemente de outras mentes, algumas já cristalizadas, a mente humana é aquela que está mais propensa a adquirir hábitos, romper com eles através da ação, estabelecendo novas crenças e novos hábitos. Trata-se, por conseguinte, de um processo evolutivo de conhecimento, de devir, pois o universo não é estático. Para ilustrar essas reflexões, escolhemos um trecho do artigo de lvo lbri, O paciente objeto da semiótica, no qual esse autor poeticamente descreve o conceito do objeto, "real" e semiótica. Assim, vejamos: 
Qual divindade entediada de sua onipotência, o poeta descobre encanto em sua impotência em anoitecer a noite. A noite diz não e o desafia a encontrar uma poesia possível escrita em uma espécie de face oculta da alteridade. Dotado pelos deuses do poder mágico de sempre dizer de modo oblíquo toda a verdade, o poeta depara agora com o efetivamente verdadeiro. Não mais poderá dizer que o universo é idéia sua, não mais poderá trair a noite: num fechar de olhos suprimir-the a existência. Algo exterior desafiadoramente permanece. Algo objeta. Algo é Objeto. É, fundamentalmente, a este ser real que Peirce se refere em sua famosa tríade semiótica: Signo, Objeto, Interpretante. Esta exterioridade sempre desafiadora que denominamos Mundo, Natureza, sedutoramente convidativa à decifração pela ciência, produção infinita de arte no dizer de Schelling. [...] Uma imediata admirabilidade suprime à consciência o tempo, e a insere novamente, desperta para a temporalidade da observação intencionalmente cognitiva. Contudo, conhecer como um transcender da mera aparência, como busca de um modo de ser, necessita da permanência e daquela independência do objeto que fará com que este negue representações falsas, ou seja, aquelas que predizem um curso dos fatos distinto do observável curso dos fatos. (IBRI, 1996, p. 115-117)

\section{Santaella e Nöth (2004, p. 160-161), observam:}

Que a semiótica é também uma teoria da comunicação, está implícito, em primeiro lugar, no fato de que não há comunicação sem signos. Em segundo lugar, está implícito no fato de que a semiose é, antes de tudo, um processo de interpretação, pois a ação do signo é a ação de ser interpretado em um outro signo. Por isso mesmo, o significado de um signo é um outro signo e assim por diante, processo através do qual a semiose está em permanente devir.

A esse processo de transitação sígnica, Peirce denomina de semiose, ou seja, o procedimento que transforma um signo em outro infinitamente. 
Na semiose, o objeto dinâmico equivale à realidade e o interpretante final à verdade. Se fosse possível o signo se desenvolver até o ponto de chegar à realização do limite do seu potencial, teríamos a revelação perfeita do objeto dinâmico, quando haveria uma superposição entre o real e a verdade. Daí o real ser sinônimo de verdade.

\title{
Charles Sanders Peirce: uma possível Filosofia da Natureza
}

\author{
Entra em teu barco do devaneio, desatraca no lago de pen- \\ samento, e deixa o sopro do firmamento encher tua vela. \\ Com teus olhos abertos, acorda para o que está à volta ou \\ dentro de ti, e abre conversa contigo mesmo; pois assim é \\ toda meditação. \\ Charles Sanders Peirce (CP 6.461)
}

De acordo com Ivo Ibri, ${ }^{3}$ a filosofia da natureza teve seu maior expoente no filósofo alemão Friedrich Wilhelm Joseph Von Schelling, que reconstrói uma filosofia na Alemanha de explosão do Romantismo, na passagem do século XVIII ao século XIX. Schelling recorria à ideia de vida, de paixão, de inspiração e de beleza, contrariando o conceito de uma visão de mundo mecanicista; um mundo que desde o século XVI fora concebido como um mundo mecânico. Nesse momento, Schelling vai presentear os seus amigos poetas com a experiência maravilhosa de contemplar, atribuir vida onde há vida, inspirado nos gregos que povoaram a natureza de deuses porque eles a enxergaram como destino de vida, de inteligência e de aperfeiçoamento. Geneticamente, para Schelling, a natureza é rica em diversidade, em qualidade, em assimetria, diferentemente de um mundo estritamente com leis mecânicas. Porém, em termos de qualidade, não há repetição, visto que todos os dias o sol se põe, a cada dia o pôr do sol é diferente e essa qualidade não se repete, a natureza é uma celebração. $O$ sentido da palavra natureza, no entanto, já mostra a particularidade do pensamento de 
Schelling, pois se trata de uma natureza concebida de modo extremamente autêntico, instaurada na verdade, como um momento de interpenetração entre necessidade e liberdade, entre real e ideal, e de encantamento pela unidade de contemplação: o espaço e o tempo em que o eu se perde numa coisa maior que é ela própria (natureza); lugar onde a razão e a memória se desmobilizam; lugar onde o eu e o não eu desaparecem; uma experiência de unidade aglutinante, de unidade agápica.

Ibri fala da natureza como o lugar onde a unidade agápica reside em plenitude, concepção semelhante ao conceito de belo que, para Schelling (2001b, p. 193), do mesmo modo, retorna sempre à natureza, pois esse conceito é, antes de qualquer coisa, a obra de arte: "Na arte, o mistério da criação se torna objetivo, e a arte é, justamente por isso, pura e simplesmente criadora”. Por ser sensível, o belo encanta, mas não tem permanência; é um jogo constante entre o particular e o geral; onde a verdade corresponde à necessidade, ao bem, à liberdade, a qualidades que são próprias da arte. Ainda, segundo Schelling (2001b, p. 193), "chamamos de bela uma figura em cujo delineamento a natureza parece ter jogado com amor, liberdade e com a mais sublime clareza de consciência, mas sempre nas formas, nos limites, da mais rigorosa necessidade e legalidade". Para esse filósofo, a arte é, por conseguinte, uma síntese ou interpretação recíproca absoluta de liberdade e necessidade. Sua filosofia nos diz que a natureza é um sistema que nunca está em repouso. Independente de nossa observação sobre seu desenvolvimento, todos os seres naturais crescem, cada um cria hábitos a depender de seu próprio tempo. A nós ela não aparece como um todo, são sempre recortes, e "o único conhecimento imediato que possuímos é do nosso próprio ser. [...] Fora de nós nunca poderemos compreender, mas podê-lo-emos se ela se realiza em nós, porque nesse caso somo-la, é ela que constitui a nossa própria natureza”. (SCHELLING, 2001b, p. 193) Na apreciação de Santaella (2000a, p. 72), Schelling queria "construir uma síntese da arte e da filosofia, na medida em que, para ele, ambas são representativas [...] e relacionadas com o corpo disponível de representações compartilháveis". Contudo, havia uma questão presente na filosofia da natureza que era chegar à inteligência, partindo da natureza, 
e para esse filósofo a natureza, como um sistema evolutivo, se desenvolve a partir de suas próprias leis.

Segundo Ibri (1992, p. 57), para Peirce, “a natureza somente parece inteligível na medida em que parece racional, ou seja, na medida em que seus processos são considerados similares a processos de pensamento”. Tal entendimento de Peirce é também reconhecido por Santaella (2000b, p. 148-149), na passagem que se segue:

A natureza é um repertório de fatos muito mais vasto e muito menos claramente ordenado do que um relatório do censo; e se a humanidade não tivesse vindo a ela com aptidões especiais para adivinhar corretamente, teríamos tudo para duvidar se, nos dez ou vinte mil anos de sua existência, suas grandes mentes teriam sido capazes de chegar à quantidade de conhecimento. [...] Todo conhecimento humano, até os mais altos píncaros da ciência, não é senão o desenvolvimento de nossos instintos animais inatos. É sempre a hipótese mais simples, no sentido de mais dócil e natural, aquela que o instinto sugere, aquela que deve ser proferida.

Consequentemente, a relação do homem com a natureza não é apenas uma relação de escolha, ou seja, o homem não se volta à natureza por vontade própria e nela tenta descobrir um mundo diferente do seu, mas, pelo contrário, homem e natureza estão ligados por elos que são inerentes à sua constituição. Ainda segundo Santaella (2004a, p. 104-106), de acordo com Peirce:

Não pode haver nenhuma dúvida razoável de que a mente humana, tendo se desenvolvido sob as influências das leis naturais, pensa naturalmente por essa razão, de um modo similar aos padrões da natureza. [...] A espécie humana desenvolveu essa faculdade provavelmente no curso do crescimento evolutivo de sua constituição física e mental. "Certas uniformidades", "certas idéias gerais de ação". Certas leis de movimento operam por todo o universo, e a mente humana, a mente raciocinante é um produto dessas leis 
altamente onipresentes. [...] $\bigcirc$ homem tem o insight natural das leis da natureza.

À luz desse entendimento, Richard Rorty assim se expressa:

Sendo parte da natureza, a mente emergiu do mesmo processo evolutivo que perpassa a biosfera. Há, consequentemente, uma conaturalidade entre a mente e o cosmos, o que significa que o homem tem uma afinidade com a natureza, está em sintonia com ela, e possui uma adaptação natural para imaginar teorias e idéias que traduzem essa sintonia. Mente e natureza desenvolvem-se juntas, esta última implantando, na primeira, sementes de idéias que irão amadurecer em comum concordância. (RORTY, 1988 apud SANTAELLA, 2004a, p. 106)

Essa teoria vai desmistificar algumas ideias presentes no pensamento humano, sobretudo na cultura ocidental, de que o homem é um ser superior que cria e domina a natureza à sua vontade. Do mesmo modo que Schelling (2001b) entende o belo como um conceito de vida, de beleza natural, beleza orgânica, beleza no sentido do sistema inteligente e dotada de telos (palavra grega que significa fim, realização, objetivo, missão), a estética - conhecida como a filosofia do belo - é também para Peirce a filosofia da admirabilidade, do que é admirável, o modo pelo qual alguém age para atingir, alcançar o ideal, a natureza da experiência puramente sensível. O sentido da palavra admirável de Peirce está contido, segundo Santaella (2004a, p. 147), nas palavras de Schelling:

O mundo ideal move-se poderosamente para a luz, mas é ainda refreado pelo fato de a Natureza se ter retirado como mistério. Os próprios segredos que residem no mundo ideal não se podem tornar verdadeiramente objetivos senão no referido mistério da Natureza. As divindades ainda desconhecidas, que o mundo ideal prepara, não podem surgir enquanto tais antes de poderem tomar 
posse da Natureza. Depois de todas as formas finitas serem destroçadas e de no vasto mundo nada existir para além daquilo que uniu os homens como intuição comum, é somente a intuição da identidade absoluta na totalidade objetiva mais perfeita.

Em Schelling (2001b), também é possível encontrar a semente do pragmatismo de Peirce: ação e conhecimento; exteriorizar o conhecimento através da ação, de um agir. É essa a noção do pragmatismo que será estudado por Peirce, que se configura por ser uma permanente construção de interpretantes, de aprendizagem, ou seja, pensar, agir e refletir sobre a ação. É nessa ação, denominada por lvo lbri (1992) de impulso semiótico, impulso cósmico, que o significado vai se construir, pois todos os seres naturais agem conforme a alma do mundo. Dessa forma, além do conceito de pragmatismo, Ibri (1992) ainda esclarece que, desde Sócrates a Peirce, somente Schelling vai falar sobre a liberdade dos fenômenos. E não foi outro o interesse de Peirce (2005), ao criar a estética e a categoria de primeiridade, conceito que já se encontrava na Grécia antiga, conhecido como acaso, ou seja, a associação de obtenção de um objetivo à perfeição, que na estética peirciana corresponde ao signo icônico, de pura liberdade. O belo, para Peirce (2005), é um dos predicados do summum bonum, e a arte é um dos canais, um dos caminhos para se chegar a uma experiência de totalidade. Contudo os conceitos de beleza e de arte não devem estar confinados ao ser humano, pois esse conceito abrange tudo aquilo que está em torno de nós, incluindo a natureza. ${ }^{4}$

Santaella (1992, p. 107-108) oferece informações adicionais que ampliam nosso conhecimento sobre a maneira pela qual Peirce entendia a arte e a ciência: com uma noção própria, uma "visão sui generis", ao estabelecer três espécies de homens:

A primeira consiste naqueles para quem a coisa está nas qualidades dos sentimentos. Esses homens criam a arte. A segunda consiste

4 Anotações das aulas do professor Dr. Ivo Assad lbri, na disciplina "Filosofia: um diálogo entre Schelling e Peirce”, ministrada na PUC/São Paulo, no segundo semestre de 2007. 
nesses homens práticos, que levam à frente os negócios do mundo. Estes não respeitam outra coisa senão o poder, e o respeitam na medida em que ele pode ser exercido. A terceira espécie consiste nos homens para quem nada parece ser grande a não ser a razão. Se a força lhes interessa, não é sob o aspecto do seu exercício, mas porque ela tem uma razão e uma lei. Para o homem da primeira espécie, a natureza é uma pintura; para os homens da segunda, ela é uma oportunidade; para os homens da terceira, ela é um cosmos, tão admirável que penetrar nos seus caminhos the parece a única coisa que a vida valeu a pena. Esses são os homens que vemos estarem possuídos pela paixão por aprender, do mesmo modo que outros têm paixão por ensinar e disseminar sua influência. Se não se entregam totalmente à paixão por aprender é porque exercitam o autocontrole. Estes são os homens científicos, e eles são os únicos homens que têm qualquer sucesso real na pesquisa científica.

Em muitas passagens dos manuscritos deixados por Peirce (apud SANTAELLA, 2004a, p. 105), vamos encontrar uma maneira poeticamente particular de ver e entender a relação entre a mente humana e a natureza, ainda que segundo um raciocínio cientificamente lógico, quando diz, por exemplo, que: "nossa faculdade de adivinhação corresponde aos poderes voadores e musicais dos pássaros, isto é, ela é para nós o que estes são para eles: o mais atirado dos nossos poderes meramente intuitivos". Assim, "a habilidade para fazer conjecturas é para o homem aquilo que o vôo e o canto são para os pássaros", [pois, na filosofia de Peirce,] o "instinto funciona como um fio comum unindo todos os seres vivos da natureza, desde os vegetais, passando pelos animais inferiores até o homem". 


\footnotetext{
Uma obra de arte é um desafio; não a explicamos, ajustamonos a ela. Ao interpretá-la, fazemos uso dos nossos próprios objectivos e esforços, dotamo-la de um significado que tem a sua origem nos nossos próprios modos de viver e pensar.

Hauser, 1988
}

Em Lendo imagens: uma história de amor e ódio (2003), Alberto Manguel, fala que, "em meados do século I d.C., no trigésimo quinto livro da sua história natural, o erudito Plínio, o Velho, escreveu que embora os egípcios reclamassem para si a invenção das artes da pintura e da escultura”, os gregos afirmavam "que essa invenção tivera lugar em Sicíone ou em Corinto”. Assim, continua Manguel (2003, p. 89): 
A filha de um certo ceramista apaixonou-se por um jovem estrangeiro. Quando chegou a época de seu amado partir, ela traçou o contorno da sombra do rosto dele em uma parede e pediu ao pai para preencher as linhas com argila, criando assim uma imagem do seu amante ausente. Apreender fielmente a realidade por meio do contraste entre sombra e luz parecia a Plínio o objetivo da arte e ele louvava, por exemplo, o trompe-l'oeil do artista Zêuxis.

Este pequeno trecho trata da noção de representação do real, que, por muitos séculos, esteve sob a responsabilidade da pintura e da escultura. Manguel (2003, p. 90) observa que, na concepção de Plínio (séc. I d.C.), a narração da "história" de Zêuxis visava "mostrar como as pinturas podem comportar um espelho fidedigno do mundo", pois o velho pensador considerava a subjetividade como algo nocivo à arte.

O conceito de representação, portanto, embora recorrente nas teorias estéticas a partir do século $X X$, é uma preocupação que vem desde a Grécia antiga e ainda suscita maiores investigações, sobretudo no que diz respeito às implicações ontológicas e semióticas. Por ser um assunto que permeia toda nossa investigação, trazemos esse conceito, à luz de vários teóricos, dando maior ênfase às principais concepções que serviram de aporte teórico a reflexões posteriores.

Charles Sanders Peirce já pretendia uma teoria geral da representação. No seu livro Semiótica (2005), um signo é aquilo que sob determinado aspecto representa algo para alguém. Vai ao encontro de alguém, criando na mente desta pessoa um outro signo. $O$ signo é uma representação de seu objeto.

$\mathrm{Na}$ semiótica peirciana, representação é apresentação de um objeto a um intérprete de um signo ou a relação entre signo e objeto, assim, representar é estar para, isto é, desempenhar uma função significativa; também podendo ser definida como distinguir entre aquilo que representa e o ato ou relação de representar; é um signo baseado numa relação de semelhança. Para Peirce (2005, p. 61), representar é: 
Estar no lugar de, isto é, estar numa relação com um outro que, para certos propósitos, é considerado por alguma mente como se fosse outro. Assim, um porta-voz, um deputado, um advogado, um agente, um diagrama, um sintoma, uma descrição, um conceito, uma premissa, um testemunho, todos representam alguma outra coisa, de diferentes modos, para mentes que os consideram sob esse aspecto.

Santaella e Nöth (1997, p. 19-20), à luz da semiótica de Peirce, entendem que:

Etimologicamente, o conceito de representação se encontra em oposição ao de “(a)presentação”. Uma representação parece, de acordo com isso, reproduzir algo alguma vez já presente na consciência. [...] A diferenciação entre um objeto (diretamente) apresentado (e, como tal, que se mostra a si mesmo) e um objeto (mediador) representado é uma diferença semiótica ontológica. [...] Objetos apresentados funcionam ontologicamente; objetos representados funcionam semioticamente.

Desde o pensamento medieval, as formas externas de manifestação das coisas são semelhanças (similitudes) das coisas. Nos Diálogos, Platão (427-347 a.C.), considerava a pintura e a escultura como imitação da imitação, daí decorrendo sua ideia e noção da arte. Ao fazer uma revisão da filosofia, Santaella (2000a, p. 26) apresenta o pensamento de alguns filósofos, entre os gregos do período de 500 a 300 a.C, que discutem o problema da duplicidade desse conceito,

que veio receber, ao longo dos séculos, as mais variadas denominações, entre elas: representação, expressão, ilusão, semblante, simulação etc., todas elas, no entanto, não passando de deslocamentos ou variações em torno do mesmo tema, o da mimese, levantado por Platão. 
Segundo Guinsburg (2006), o filósofo grego vai declarar sua idéia de arte, sobretudo as artes plásticas, como algo que está bem longe da verdade, mas no imitador.

Mimese, portanto, é uma imitação bem-sucedida do mundo natural, o que desloca seu conceito do sentido de cópia para o de representação, esta última entendida não como reprodução, mas como apresentação de algo como se fosse real. Ainda segundo Santaella (2000a, p. 27), "em Aristóteles a significação de representação inclui a verossimilhança, que significava o estabelecimento de representações convincentes, internamente procedentes". Ao considerar a beleza como uma propriedade objetiva de uma obra de arte e mesmo da natureza, "em lugar da busca do Belo que Platão considerava como um dos fins últimos da arte, [Aristóteles] deslocou sua ênfase para os benefícios morais que a arte pode trazer". (SANTAELLA, 2000a, p. 31)

O significado da palavra mimesis já diz: "imitação", é a ação de imitar; cópia, reprodução ou representação da natureza. Vejamos, no trecho a seguir, algumas considerações sobre esse conceito:

[...] o que constitui, na filosofia aristotélica, o fundamento de toda a arte. Heródoto foi o primeiro a utilizar o conceito e Aristófanes, em Tesmofórias (411), já o aplica. O fenômeno não é exclusivo do processo artístico, pois toda atividade humana inclui procedimentos miméticos como a dança, a aprendizagem de línguas, os rituais religiosos, a prática desportiva, o domínio das novas tecnologias etc. Por esta razão, Aristóteles defendia que era a mimesis que nos distinguia dos animais. Os conceitos de mimesis e poeisis são nucleares na filosofia de Platão, na poética de Aristóteles e no pensamento teórico posterior sobre estética, referindo-se à criação da obra de arte e à forma como reproduz objectos pré-existentes. $\bigcirc$ primeiro termo aplica-se a artes tão autônomas e ao mesmo tempo tão próximas entre si como a poesia, a música e a dança, onde o artista se destaca pela forma como consegue imitar a realidade. Não se parte da idéia de uma construção imitativa passiva, como acontece 
na diegesis platónica, mas de uma visão do mundo necessariamente dinâmica. A mimesis pode indiciar a imitação do movimento dos animais ou o seu som, a imitação retórica de uma personagem conhecida, a imitação do simbolismo de um ícone ou a imitação de um acto musical. Estes exemplos podemos colhê-los facilmente na literatura grega clássica. As posições iniciais de Platão, na República, para quem a imitação é sobretudo produção de imagens e resultado de pura inspiração e entusiasmo do artista perante a natureza das coisas aparentemente reais (o que se vê em particular na comédia e na tragédia), e de Aristóteles, na Poética, para quem o poeta é um imitador do real por excelência, mas seu intérprete, função que compete ao cientista, foram largamente discutidas até hoje. Em particular, a questão da poesia ainda permance em aberto: seguimos com Platão se aceitarmos que a imitação fica ao nível da lexis, ou seguimos com Aristóteles, se aceitarmos que todo o mundo representado ou logos está em causa e que não resta ao artista outra coisa que não seja descrever o mundo das coisas possíveis de acontecer, coisas a que chamamos verossimilhanças e não propriamente representações directas do real? Os tratadistas latinos, como Horácio, vão defender o princípio aristotélico, reclamando que a pintura como a poesia (ut pictura poesis), por exemplo, são artes de imitação. A semiótica contemporânea substituiu o conceito de imitação pelo conceito de iconicidade nos estudos literários.

Mais tarde, já no século XX, a Escola de Frankfurt, sobretudo através de Theodor Adorno e Walter Benjamin, foi considerada um marco filosófico para entender as constantes transformações nas artes visuais, especialmente em relação à fotografia, aos estudos sobre a cultura de massa e à tecnologia. Em se tratando de um sistema semiótico, o conceito de representação, nesse sentido, está associado ao signo, trânsito do signo, imagem, significação, referência etc. Segundo Santaella (2007, p. 356), à luz do pensamento de Rudolf Arnheim,

1 Disponível em: 〈http://www2.fcsh.unl.pt/edtl/verbetes/M/mimesis.htm〉. Acesso em: 2007. 
A representação pictórica pressupõe mais do que a formação de um conceito perceptivo. Deve-se encontrar um modo de traduzir o percepto em forma tangível. Obviamente essa empresa não é desempenhada pelo lápis ou papel, mas pela mente que guia o lápis e julga o resultado. Isto requer o que proponho chamar de conceito representativo. [...] A tradução de conceitos perceptivos em padrões que podem ser obtidos de um estoque de formas disponíveis num médium particular precederá o desenho real, continuará durante o desenho, e novamente será influenciado pelo que aparece no papel. Conceitos representativos são dependentes do meio através do qual eles exploram a realidade.

Santaella (2007, p. 356) complementa a citação acima, assegurando que:

Toda imagem representada, ou seja, corporificada em um suporte de representação, coloca em ação conceitos representativos que são próprios daquele suporte ou dispositivo. No caso do desenho ou pintura, os conceitos representativos devem ser de conhecimento da criação do autor das imagens. [...] Quanto ao receptor da imagem, este também deve ter pelo menos certa familiaridade com os conceitos representativos, caso contrário a imagem não será decodificada como tal.

Santaella (2003a, p. 224) amplia as definições do termo "representação", ao informar que o conceito de continuum difere, em todos os sentidos, das visões dicotômicas da representação versus não-representação ou antirrepresentação. E Santaella e Nöth (1997, p. 15-16), compreendem que:

O conceito de representação tem sido um conceito chave da semiótica desde a escolástica medieval, na qual esta se referia, de maneira geral, a signos, símbolos, imagens e várias formas de substituição. Hoje o conceito se encontra no centro da teoria da ciência cognitiva, que trata de temas como representação analógica, digital, propo- 
sional, cognitiva ou, de uma maneira geral, representação mental. Na Semiótica geral, encontram-se definições muito variadas do conceito de representação. $\bigcirc$ âmbito da sua significação situa-se entre apresentação e imaginação e estende-se, assim, a conceitos semióticos centrais como signo, imagem (representação imagética), assim como significação e referência.

De acordo com Hanna Fenichel Pitkin (1967), o termo "representação" tem o significado de imagem, figura ou pintura, a partir do século $X V$, e não obstante os gregos antigos terem tido contato com essa nomenclatura, eles não tinham uma palavra ou um conceito correspondente, visto que, segundo Lagarde (1937, p. 425), sua origem é latina, repraesentare, "tornar presente ou manifesto; ou apresentar novamente". No latim clássico, seu uso é quase inteiramente reservado a objetos inanimados, ou seja, tornar esses objetos literalmente presentes, trazê-los à presença de alguém. Representação, para Pitkin (1967), significa tornar presente uma abstração em um objeto, ou por meio dele, como ocorre quando uma virtude surge encarnada na imagem de certo rosto; substituir um objeto por outro - em vez do outro; antecipar um evento -, trazendo-o para o presente; tornar presente de alguma forma, apesar disso não estar literalmente presente. Assim como objetos inanimados, a representação na pintura ou na escultura se encontra na natureza fictícia da conexão e ocupa o lugar de/ou corresponde a algo.

Assim, ao discorrermos sobre a paisagem, sabemos que a pintura de uma paisagem não trata de uma paisagem real, mas de uma paisagem apenas por representação, valendo também para associações com outros objetos. Do mesmo modo, os seres humanos não estão completamente ausentes desses primeiros usos, pois representar é uma atividade humana, mas não um agir para outros; é a atividade de apresentar, de figurar, de pintar um quadro ou encenar uma peça. Alguns tipos de representação podem ser obtidos através da imagem, de rastro, espelho, impressões (permanentes ou efêmeras), dentre tantas outras. 
Para Barthes (1977), representação são formações, mas são também deformações. Como nos afirma Brian Wallis (1991, p. xv), "nosso acesso à realidade é mediado por um olhar plasmado da representação. Ao se representar algo, está implícito o processo de apresentação de alguma coisa”.

Também nas reflexões de Emmanuel Lévinas, o conceito ora em discussão aparece em "ruína da representação", como um termo que assegurava à tradição filosófica o próprio contato com o real. Segundo Lévinas (2004, p. 69), Husserl, em seus estudos lógicos, realizados no início do século passado, "embora preparando a ruína da representação, sustenta a tese de que todo fato psicológico é Representação ou está fundado sobre uma Representação", e continua:

Por representação é preciso entender a atitude teorética contemplativa, um saber, quer seja de origem experimental, quer repouse sobre sensações. A sensação precisamente sempre foi tomada por um átomo da representação. $O$ correlativo da representação é um ser posto, sólido, indiferente ao espetáculo que se oferece, dotado de uma natureza e, consequentemente, eterno, mesmo que mude, porque a fórmula de sua mudança é imutável, as relações que ligam tais seres, configurações de tais seres, dão-se elas também à representação. Antes de agir, antes de sentir, é preciso representar-se o ser sobre o qual vai incidir a ação, ou que suscita o sentimento. A afetividade por si mesma só abarca estados interiores. Não nos revela nada do mundo.

Na mesma linha de pensamento dos autores já mencionados, Danto (1998, p. 105) assinala que "existe um conceito primordial de representação no qual o que está representado é aceito como algo verdadeiramente presente na representação". O poder da imagem pertence mais ao ser ou entidade capturada do que na própria imagem". E complementa (1998, p. 106): "sentimos o amado desaparecido viver nas imagens - onde o que está representado é sentido como se estivesse contido ou presente na representação". Esta colocação ilustra o impulso de beijar a fotografia de 
uma pessoa amada, especialmente quando ela não está mais presente no convívio daquele que a contempla e beija.

A arte, portanto, é um campo aberto a reflexões e discussões infindáveis no qual, por maiores aprofundamentos e especulações, ainda que possam parecer convincentes, sempre existe algo que paira no ar, sem explicações concretas. A discussão nasce do paradoxo inerente ao seu próprio significado, que aponta para duas questões: a primeira, sobre a iconicidade do signo da arte. A segunda, própria da cultura ocidental: para que a arte serve, ou seja, qual é sua função? Para o homem ocidental algo sempre deve servir para alguma coisa, sobretudo em sociedades capitalistas, e parece que de alguma forma tal função não constituía maiores preocupações quando a arte esteve ligada à ideia de representação. Contudo, a partir de cada década do século $X X$, essa questão se agravou e se tornou mais evidente com a presença desafiadora das vanguardas, ao negarem o objeto arte. Aquele objeto, que possuía nome próprio - Pintura e Escultura -, com suas regras definidas, com artistas que sabiam ser virtuosos em suas técnicas, buscando representá-lo da maneira mais fiel à qual ele aparecia aos seus olhos, estava ameaçado.

\section{Natureza}

Antes de apresentarmos as principais considerações referentes a este assunto, trazemos inicialmente duas questões que servirão de base para nossas reflexões, a saber: 1. $\bigcirc$ que é a natureza? 2. Qual a sua relação com as artes visuais?

Ao entrarmos no verbete natureza, são inúmeros os significados que os dicionários e enciclopédias nos oferecem, a saber: o mundo material e seus fenômenos; as forças e processos que produzem e controlam todos os fenômenos do mundo material; as leis da natureza; o conjunto de todos os seres e forças que formam o universo e dos fenômenos que nele se produzem; força ativa que estabeleceu e conserva a ordem natural de tudo o que existe; conjunto de coisas visíveis enquanto meio onde o homem vive; 
ordem natural do universo; o mundo de coisas vivas; as belezas da natureza; estado primitivo de existência intacto e sem influência de qualquer tipo de civilização ou artificialidade etc.

Ao longo da história evolutiva da concepção de natureza, encontramos uma variedade de teorias e conceitos, dos quais destacamos os que mais se aproximam do nosso assunto, presentes na arte e na filosofia da natureza, em autores como Charles Sanders Peirce, Gilles Deleuze, Felix Guattari, Friedrich Wilhelm Joseph von Schelling, Ivo Ibri, John Berger, Lucia Santaella, Ralph Waldo Emerson, Regis Debray, dentre outros.

Iniciamos com Ralph Waldo Emerson, poeta e filósofo americano, considerado um dos grandes pensadores que influenciaram intelectuais, poetas e artistas do final do século XIX até a nossa atualidade. Emerson semeou as sementes do movimento americano denominado Transcendentalismo, ao compreender a importância do espiritual interior sobre o material exterior no kantismo, no neo-platonismo, no romantismo e na metafísica, além das obras de Santo Agostinho, Samuel Taylor Coleridge e William Shakespeare. Em sua obra Nature, escrita em 1836, Emerson (1983a) apresenta uma ideia de natureza com todos os seus elementos e fenômenos integrados ao homem. Nos trechos que se seguem, destacamos passagens dessa obra, com um destaque especial à noção que esse autor dedica à arte (1983b).

O sentido predominante em Emerson (1983b) é o de uma exposição em poesia; um alto discurso, a voz de um orador que parece respirar tanto o ar que vem da paisagem como do seu próprio corpo. Ao se referir ao universo, à natureza, ele inclui todas as coisas que existem independentes da vontade do homem, são as coisas reais. À arte são aplicadas misturas dessas coisas com o desejo do homem de construir, a exemplo de uma casa, um canal, uma estátua, um quadro etc. Mas essas atividades do cotidiano humano são para ele insignificantes frente à magnificência da natureza. Essa obra é um convite à contemplação dos elementos e fenômenos naturais, pela qual Emerson (1983b, p. 8-9) questiona:

Por que nós também não devemos gozar de uma relação original com o universo? Há mais lã e linheiro nos campos. Há novas terras, 
novos homens, novos pensamentos. Deixe-nos erigir nossos próprios trabalhos, leis e adoração. [...] Mas se um homem estiver sozinho, deixa-o olhar as estrelas. Os raios que vêm desses mundos celestiais o separarão do que ele pode tocar, [...] a atmosfera pode transmitir a impressão de ter sido feita transparente para poder dar, em forma de corpos celestiais, a perpétua presença do sublime. [...] As estrelas despertam certa reverência, porque embora sempre presentes, elas são inacessíveis; mas todos objetos naturais causam uma impressão aparente, quando a mente está aberta à sua influência. A natureza nunca usa uma aparência mesquinha. Nem faz o homem mais sábio extorquir seu segredo, e perde sua curiosidade por descobrir toda sua perfeição. A natureza nunca se tornou um brinquedo a um espírito sábio. As flores, os animais, as montanhas, refletiram a sabedoria da sua melhor hora, tanto como tinham encantado a simplicidade da sua infância.

Desse modo, trata-se da inteireza de uma impressão que temos a partir da maneira pela qual vemos as coisas; um convite para distinguir entre as coisas que o homem extrai da natureza para uma determinada função, das coisas que servem de inspiração para os artistas. Entretanto, trata-se de uma relação de comunhão e não de posse, pois, de acordo com Emerson (1983b, p. 9), "o homem pode ser dono de muitas terras, mas nenhum deles pode ser dono da paisagem", visto que existe uma propriedade no horizonte que só pode ser percebida por aqueles que têm olhos para integrar todas as partes, o poeta. "Quais anjos criaram esses ornamentos esplêndidos, repletos de coisas que lhes servem, como as bestas, o fogo, a água, as pedras, e o milho?” - indaga Emerson (1983b, p. 12). Para ele, o campo é ao mesmo tempo seu chão, seu trabalho, seu pátio de recreio, seu jardim e sua cama. A natureza, destarte, não é apenas material, senão o processo e o resultado; todas as partes que trabalham incessantemente com suas próprias mãos para o bem do homem, como o vento que semeia a semente; o sol que evapora o mar; o vento que sopra o ar em direção ao campo; a chuva que alimenta a planta; a planta que alimenta o animal; 
e assim o ciclo interminável que esse autor denomina de caridade divina que nutre o homem. Existem nas suas palavras afinidades com as filosofias de Peirce e Schelling. Para Peirce (2005), esse processo de crescimento está presente no continuum, no pragmatismo, no projeto agápico, assim como no conceito de admirável. E o belo? Como ele surge? Vejamos as colocações de Emerson:

desejo mais nobre do homem é servido pela natureza, a saber, o amor da Beleza. Os gregos antigos chamaram o mundo kosmos, beleza. Tal é a constituição de todas as coisas, ou tal o poder plástico do olho humano, que as formas primárias, como o céu, a montanha, a árvore, o animal, nos dão um encanto em e para si; um prazer que surge do contorno, da cor, do movimento e do agrupamento. $\bigcirc$ olho é a melhor parte dos artistas. Pela ação mútua de sua estrutura e das leis da luz, da perspectiva que é produzida, que integra cada massa de objetos, [...] a paisagem que eles compõem, é redonda e simétrica. E como o olho é o melhor compositor, então a luz é o primeiro dos pintores. [...] Não há nenhum objeto que a luz intensa não consiga transformá-lo em belo, e é esse estímulo que dá recursos aos sentidos, como espaço e tempo, que torna tudo alegre. Mas além dessa graça geral difusa sobre a natureza, quase todas as formas individuais tornam-se agradáveis aos olhos, como é provado por nossas imitações intermináveis de algum deles, como a uva, a pinha, a espiga de trigo, o ovo, as asas e a maioria das formas de pássaros, a garra do leão, a serpente, a borboleta, conchas, chamas, nuvens, brotos e as formas de muitas árvores, como a palma. [...] Mas em outras horas, a Natureza satisfaz-se com seu próprio encanto, e sem qualquer mistura de benefício corporal. [...] Eu conspiro com o vento de manhã. [...] Vejo o espetáculo da manhã sob o cume da colina frente à minha casa, do amanhecer à alvorada, com emoções que talvez apenas um anjo possa compartilhar. (EMERSON, 1983b, p. 14)

Todos os homens estão em algum grau impressionados com a face do mundo; alguns chegam até a se deleitar. Este amor de beleza é 
Gosto. Outros têm o mesmo amor em tal excesso, que, não contentes em apenas admirar, procuram abrangê-lo em novas formas. A criação da beleza é a arte. [...] A produção de um trabalho de arte joga uma luz sobre o mistério da humanidade. Um trabalho de arte é um resumo ou epítome do mundo. É o resultado ou expressão da natureza em miniatura. Porém, embora os trabalhos da natureza sejam inumeráveis e todos diferentes, o resultado ou a expressão deles são todos semelhantes e únicos. A natureza é um mar de formas radicalmente semelhante e ao mesmo tempo raro. Uma folha, um raio de sol, uma paisagem, o oceano, causam uma impressão análoga na mente. $\bigcirc$ que é comum a todos eles é essa perfeição e harmonia, é beleza. $O$ padrão de beleza é o circuito inteiro de formas naturais, a totalidade da natureza que os italianos expressaram como “nell de piu de il'uno". Nada é totalmente belo sozinho: nada, mas é belo na sua inteireza. [...] Um único objeto só é belo como sugestão de sua graça universal. $\bigcirc$ poeta, o pintor, o escultor, o músico, o arquiteto, cada um deles procura concentrar esse fulgor do mundo em um ponto, e cada um, em seus vários trabalhos satisfaz o amor da beleza que o estimula produzir. (EMERSON, 1983b, p. 18)

O cenário delineado é de uma paisagem bucólica, um mar silencioso, mas, para compartilhar desse espetáculo, é necessário perceber (conceito que em Peirce significa participar de um evento com todos os sentidos); e é assim que Emerson (1983b) diz partilhar das transformações rápidas que acontecem ao entardecer, quando a luz muda o cenário em segundos. Decorrente desse pensamento, a arte não pode competir nem acompanhar esse movimento natural e contínuo, por mais determinada que ela seja, todos os seus elementos integram um processo continuum, pois:

Os céus mudam a cada momento e refletem sua glória ou melancolia nas planícies abaixo. $\bigcirc$ estado da colheita nas fazendas adjacentes altera a expressão da terra a cada semana. A sucessão de plantas nativas nos pastos e arredores, que faz com que o relógio silencioso conte as horas de verão, fará as mesmas divisões do dia sensíveis 
ao observador entusiasta. As tribos de pássaros e insetos, como as plantas pontuam a seu próprio tempo, seguem uns aos outros, e o ano tem lugar para todos. (EMERSON, 1983b, p. 15-16)

Realmente a arte não pode concorrer com essa grandeza de cores, pois o rio é uma gala perpétua e se vangloria a cada mês em um novo ornamento que depende exclusivamente do tempo.

\section{Paisagem - Landscape}

Tudo nos leva a crer que existe paisagem diante de nós, antes de nós, uma "bela natureza". Apenas depois chega o poeta, o artista, para expressar essa beleza na tela ou no papel. [...] Para se impor ao olho, como qualquer objeto de cultura, a paisagem pressupõe muitas mediações.

Regis Debray, 2003

Segundo Regis Debray (2003, p. 76), a palavra paisagem, cenário, vem do francês paysage, supostamente cunhada por Robert Estienne, em 1549, sendo associada "ao gênero de pintura que representa os campos e os objetos que nele se encontram. Ela designava não um campo, mas uma espécie de pintura". Ainda segundo este mesmo autor, "a paisagem como gênero pictórico repousa em dois postulados universais: 1) a natureza deve ser representada, e 2) a natureza pode ser representada (em duas dimensões, numa superfície plana)". Mas, como os primeiros que se interessaram por esse tipo de representação, os pintores tiveram que encontrar meios representativos próprios.

Antes da perspectiva, a qualidade simbólica dos objetos representados determinava sua grandeza relativa. A falta de elementos desconexos tornava a paisagem impossível. Somente a disposição geométrica proporciona as regras de uma junção, deixa ver os nexos entre as coisas. Anteriormente, o relato, o tema e a intriga davam coerência ao que era visto. A perspectiva permite representar sem 
narrar. A paisagem é justamente isso: é o momento que a pintura se descola do relato religioso, mitológico ou literário. Quando não existe outro assunto além da própria natureza, por meio de uma superação de conteúdo e de forma. (DEBRAY, 2003, p. 83)

A partir do século XVII, a pintura de paisagem passa a questionar o espaço real através da perspectiva, num mundo vago e irreal, e não obstante serem inúmeros os significados para essa palavra, existe um consenso tradicional em glossários que associa esse termo a um espaço territorial determinado pelo olhar, o que aparece e o que pode ser visto numa extensão ou espaço. E o que surge não é um todo, é apenas um recorte, no qual está presente um sistema vital complexo e dinâmico em processo contínuo de evolução, ou seja, um espaço sígnico. Assim, observa Debray (2003, p. 76), "a paisagem designa tudo aquilo que o olhar abrange. Resta designar os princípios da visão, os quais não são vistos a olho nu. Tanto isso é verdade que vemos tudo menos aquilo que nos permite ver”.

Schelling (2001b, p. 2) faz referência a vários filósofos dessa corrente, que entendem esse tipo de pintura como um espaço cuja luz é exterior, móvel e, portanto, vivo. "[...] Por isso, por toda a pintura de paisagem só é possível exposição subjetiva, pois a paisagem só tem realidade no olho daquele que a contempla”.

À luz de Friedrich Wilhelm Joseph von Schelling (2001b), a pintura de paisagem é entendida como algo extraído da natureza, que evoca sensações àquele que a contempla. No trecho que se segue podemos entender melhor sua visão sobre esse argumento:

A pintura de paisagem busca empiricamente a verdade empírica, e o mais alto de que é capaz é utilizar a esta mesma novamente como um véu através do qual deixa entrever uma espécie superior da verdade. Mas o que se expõe é tão somente o véu: o verdadeiro objeto, a Idéia, permanece sem figura, e sua descoberta naquilo que é vaporoso e o que informa passa a depender daquele que contempla. É inegável que as relações da luz universal com um 
amplo todo de objetos - se ela paira sobre a natureza de uma maneira mais manifesta ou mais velada, mais forte e distinta ou mais fraca e como que flutua sobre ela - evocam certos estados da alma, despertam, indiretamente, Idéias ou, antes, apenas fantasias de Idéias, e não raro tiram de nossa vista o véu que recebe o mundo invisível. Mas toda intenção dessa espécie incide no sujeito. Vemos que, quanto mais pobre a poesia de uma nação, tanto mais tende para uma tal ausência de forma. Quanta ocasião não há em Homero para descrever paisagens e, no entanto, nenhum vestígio disso nele. [...] A beleza de uma paisagem depende de tantas casualidades, que é difícil, é impossível the dar na arte aquela necessidade que, por exemplo, toda figura orgânica contém em si. Não são as causas internas, mas externas e violentas que determinam a forma, o declive das montanhas e as ondulações dos vales. Supondo-se que, na própria paisagem que expõe amplamente diante de nós, saiba ao mesmo tempo nos expor os fundamentos e as leis de sua formação, o curso do rio que forma vales e montanhas, ou a força do fogo subterrâneo, que despeja de uma só vez destruição e lavas de abundância sobre uma região; supondo-se que saiba expor tudo isso, o próprio momento da luz que escolhe, o grau de luminosidade ou escurecimento que paira sobre o todo permanece, no entanto, uma contingência, e já que é propriamente a esta que ele expõe e torna objeto. (SCHELLING, 2001b, p. 193)

Nas palavras de Schelling (2001b), vemos certa semelhança com o discurso poético de Emerson (1983b) - ambos estão voltados para a filosofia da natureza -, e a arte para eles, mais especificamente a paisagem, não pode representar de uma maneira fidedigna os elementos naturais em toda a sua exuberância.

Já o termo landscape aparece por volta do final do século XVI, com os pintores holandeses. Originalmente, referia-se à região, área de terra, cenário, panorama, vista. Mais tarde, passou a ser associado, no sentido artístico, a um quadro retratando a terra. As paisagens são também consideradas um gênero pictórico, cujas origens remontam aos planos secundários, a 
exemplo dos registros de viagem de Albrecht Dürer, e nesse sentido, esses dois termos se aproximam em vários aspectos.

A paisagem abrange as características visíveis de uma área de terra, incluindo elementos físicos tal como landforms, elementos da flora e da fauna, elementos abstratos e elementos humanos. A primeira paisagem registrada, aproximadamente em 1598, foi emprestada como um termo desses pintores holandeses, landschap que, em holandês, mais cedo significava simplesmente região, área de terra. Em dicionários e enciclopédias, essa palavra significa um quadro representando uma vista de uma paisagem interior natural: a arte de retratar esse cenário; porção de um território, apreendido pelo olhar de um só lugar; uma área particular de atividade. Levando em consideração outros autores, a exemplo de Berger (1987, p. 105), a pintura de paisagem começa na Holanda com o problema de se pintar a distância do céu; uma paisagem pura que não respondeu a nenhuma questão de ordem social, um gênero de pintura relativamente independente.

Mais tarde, durante o Romantismo, o artista representa campos, montanhas, rios, céu - a exemplo de John Constable, Caspar David Friedrich, Joseph Mallord William Turner, o Grupo de Paisagistas Franceses, a Escola de Barbizon, sob a liderança de Théodore Rousseau, Gustave Courbet, dentre outros - de uma maneira bastante específica. John Constable, um dos pintores mais importantes desse período, ficou conhecido por pintar como um poeta e escrever como um pintor, dedicando-se à paisagem do realismo sentimental, em que a presença do tempo não podia ser representada num espaço fixo como a tela. Mas isso não o impedia de sentir o movimento constante do passar do tempo, pois esse fenômeno que tornava a natureza sedutora o encantava, sobretudo pela sua incapacidade de se mostrar por inteiro. Por isso, dedicava horas do seu tempo a contemplá-la, observando a silenciosa mudança da luz, que iluminava e sombreava os campos - às vezes banhando-os de claridade -, outras vezes deixando que as nuvens refletissem sombras sobre eles. $E$ se não conseguia passar tudo isso para a tela, seu espírito se regozijava e se nutria desse constante desejo. 
A pintura romântica alemã também tem destaque com Caspar David Friedrich e sua obra encontra-se junto a pintores e escritores contemporâneos do Romantismo, alemão e inglês, no período do final do século XVIII e início do século XIX, como Joseph Mallord William Turner, Georg Philipp Friedrich von Hardenberg (mais conhecido pelo pseudônimo Novalis) e Johann Wolfgang von Goethe, um dos líderes do movimento literário romântico alemão, denominado Sturm und drang (Tempestade e ímpeto). Durante essa época, a pintura evoca uma cumplicidade entre o sentimento do artista e os fenômenos naturais, consubstanciando-se em um só, que Schopenhauer, nas suas preleções na Universidade de Berlim, em 1820, expressa, a seguir:

Vemos em cada paisagem o mundo como representação em um grau significativo de objetividade da vontade. [...] A idéia é o objeto da arte. [...] A arte repete em suas obras as Idéias apreendidas por pura contemplação, o essencial e permanente de todos os fenômenos do mundo, de acordo com o material em que ele repete. Sua única origem é o conhecimento da Idéia; seu único fim, a comunicação desse conhecimento. (SCHOPENHAUER, 2003, p. 58)

A pintura de paisagens - na medida em que reflete em imagens as Idéias apreendidas, nela reside nesse domínio a inteira natureza destituída de conhecimento. [...] $\bigcirc$ pintor nos deixa de fato ver as coisas pelos seus olhos, nos torna participantes de sua apreensão puramente objetiva, e justamente por isso recebemos, ao mesmo tempo, uma sensação comum e um sentimento repleto do silêncio da vontade, o qual tinha de existir no pintor quando este emergiu de forma tão completa. Seu conhecimento nos objetos sem vida e sem conceito. (SCHOPENHAUER, 2003, p. 152)

Ao afirmar "o mundo é a minha representação", Schopenhauer em sua obra $O$ mundo como vontade e representação, publicada em quatro volumes em 1819, fala que a arte traz consigo a vontade do pintor, isto é, uma sensação de sentimento que devia existir a partir do próprio pintor ao 
passar para a obra esse sentimento. Portanto, ao criarem suas paisagens, elas pareciam estar carregadas de mistério, pathos e simbolismo; e quando havia a presença do homem, esse aparecia como uma figurinha perdida na vastidão de campos, mares, geleiras, montanhas etc. $E$ assim entendida, “a paisagem é um exterior revisado, refeito por uma alma, mesmo sendo verdade que a paisagem não é uma coisa, mas sim uma relação com as coisas”. (DEBRAY, 2003, p. 78)

Já a tradição dessa pintura nos Estados Unidos, que culminou com a Hudson River School, em grande parte expressou o choque de uma natureza indômita de invisibilidade e intervenção de civilização - isto é, as paisagens panorâmicas com seus efeitos cósmicos. Hudson River School foi um movimento da arte americana da metade do século XIX, entre 1855 e 1875 , formado por um grupo de pintores de paisagem, cuja visão estética foi influenciada pelo Romantismo, e onde se destacam Thomas Cole e Asher Durand. Suas pinturas retratam o vale do rio Hudson e áreas adjacentes, assim como as montanhas Catskill, Adirondack e as White Mountains, de New Hampshire. A “escola”, neste sentido, refere-se a um grupo de pessoas, cuja perspectiva, inspiração, produção ou estilo demonstram um interesse em comum e não, necessariamente, uma instituição acadêmica. Thomas Cole, considerado o fundador desta escola, de origem inglesa, nascido numa paisagem verde monocromática, encantou-se com os tons brilhantes de outono dessa área. As pinturas desse movimento refletem três temas da América do século XIX: descoberta, exploração e assentamento (formação de comunidades). As pinturas também retratam a paisagem americana como um cenário pastoral, onde o homem e a natureza coexistem pacificamente. Em geral, esses pintores acreditaram que essa natureza na forma da paisagem americana era uma manifestação inefável de Deus, independente das diferentes religiões existentes entre os membros do grupo. Suas inspirações estavam voltadas para mestres europeus, como Claude Lorrain e John Constable, e J. M. W. Turner também compartilhou a reverência pela beleza natural da América com os escritores americanos Henry David Thoreau e Ralph Waldo Emerson. A segunda geração de artistas desta escola emergiu depois da morte prematura de Cole, em 1848, 
com os pintores Frederic Edwin Church e Albert Bierstadt. O tamanho épico das paisagens nestas pinturas lembra as vastas áreas do deserto americano, e em muito contribuíram para um olhar ao oeste desse país como um lugar privilegiado, mais tarde com a preservação e conservação dessas áreas como parques nacionais e patrimônio histórico.

No entanto, a pintura de paisagem não se deu em todos os lugares, e.g. na Grécia antiga, a inexistência desse gênero de pintura se dá em face da falta de função dessa representação, pelo fato de que a "imagem sagrada não estava para um ideal de semelhança, mas de significação”. (DEBRAY, 2003, p. 81) Nesse contexto, inexistia uma demanda de encomenda desse estilo, visto que a imagem pintada era impulsionada pela necessidade de elevar o olhar ao espírito, aos deuses, enquanto a paisagem poderia significar o entendimento de um retorno à terra. Se todas as representações possuíam um significado próprio, a exemplo de uma árvore que tinha o poder de representar o campo; uma torre que significava poder etc., essa representação como resultado de um ato de contemplação, seja por parte do artista, seja por parte do receptor, não tinha função nem finalidade.

Deste modo, "durante um milênio, a paisagem não foi um fragmento do mundo, mas, sim, uma idéia do mundo. Os dois, a bem dizer, não se separavam". (DEBRAY, 2003, p. 81) Por conseguinte, a paisagem pode ser considerada como imagem, signo que tem na sua história uma relação estreita com o olhar; com a percepção de um respectivo espaço, um recorte que determina uma representação construída a partir de um processo imaginário. E a partir dessas transformações, mais tarde "o desaparecimento da paisagem na pintura de vanguarda, do início do século XX [...] prefigurava, sem dúvida, a passagem dos antigos terrenos para um novo entorno abstrato". (DEBRAY, 2003, p. 83-84) E enquanto a arte volta-se para uma nova conquista, a abstração, onde as formas não têm compromisso com a representação de uma semelhança do real, várias questões são levantadas quanto ao rumo da arte, como nos informa Debray (2003, p. 83-84):

Por ser a última da fila na escala social dos gêneros, a paisagem pôde se tornar o ponto de ebulição da pintura. Menos codificado, 
portanto menos vigiado, portanto mais livre. Os gêneros desdenhados são os mais revolucionários. $\bigcirc$ não-figurativo chegou até nós por essa portinhola, primeiro com Turner, que dava atmosfera às formas, depois com Kandinsky, no início do século 20. Não terá sido a primeira tela "abstrata" uma paisagem em aquarela de 1910? [...] O planeta passaria a sonhar com jardins, viveria do fantasma das obras de arte, das hortus conclusus, se já não soubesse da ameaça que paira sobre sua sobrevivência?

Quanto a essa questão, em nome do progresso, Schelling (2001b, p. 193) já antevia que "o mundo moderno começa quando o homem se desprende da Natureza, mas se sente abandonado, já que não conhecia outra terra natal”. No entanto, se a representação da paisagem já havia deixado de seduzir os artistas, como sugere Santaella (2003a), devemos olhar sempre para o que os artistas nos dizem, pois são eles que assinalam para os novos rumos da arte. E é possivelmente no ambiente físico da América, a partir dos anos 1930, que esses rumos são notadamente alterados, pois se observam representações abstratas, presentes na série de pinturas em que Georgia O'Keeffe retrata a cidade (Cityscape), de forma semelhante a John Sloan, Alfred Stieglitz e Joseph Stella, que pintaram as formas modernas da cidade de Nova lorque. Essas condições são resultantes das mudanças pelas quais a cultura moderna se anuncia, visto que, como esclarece Santaella (2007, p. 137), "a existência de toda arte é cultural e socialmente sobredeterminada”.

Com o surgimento de outras espécies de paisagem, como a urbana, verifica-se um deslocamento e, ao mesmo tempo, uma união entre a natureza e outros meios de representação, uma intercepção que insere outras áreas do conhecimento humano, ou seja, uma paisagem cognitiva que envolve questões de ordem subjetiva do sujeito, do objeto, da fenomenologia, bem como apreensão, percepção, recepção, identidade, alteridade, memória etc.

A partir das considerações apresentadas, podemos concluir que as atribuições sígnicas à natureza indagam sobre o conceito de lugar e es- 
paço/tempo; locais permeados de significação que, mesmo com todas as alterações provenientes da relação entre o homem e o progresso, esses desdobramentos advindos da paisagem do século $\mathrm{XVI}$ até o século $\mathrm{XIX}$, que homenageiam a natureza na sua plenitude, sempre serão lembrados, pois, como afirmam Deleuze e Guattari (1992, p. 219):

A paisagem vê. Em geral, qual o grande escritor que não soube criar esses seres de sensação que conservam em si a hora de um dia, o grau do calor de um momento (as colinas de Faulkner, a estepe de Tolstoi ou a de Tchekov)? O percepto é a paisagem anterior ao homem, na ausência do homem. [...] É o enigma (freqüentemente comentado) de Cézanne: 'o homem ausente, mas inteiro na paisagem?.

\section{Natureza da Arte: Martin Heidegger}

Antes de dar início à reflexão sobre a natureza da arte, à luz do filósofo Martin Heidegger, abordaremos sucintamente o conceito de hermenêutica. De acordo com Palmer (1985), o termo "hermenêutica" etimologicamente remonta ao verbo grego hermeneuein, traduzido por "interpretar", e ao substantivo hermeneia, "interpretação", objeto do tratado intitulado Peri

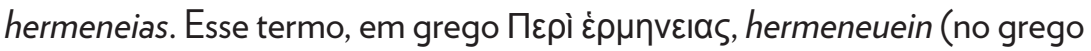

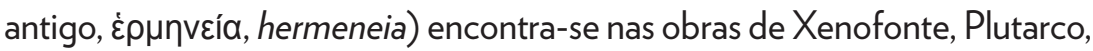
Eurípides, assim como nos sofistas, na interpretação dos mitos gregos, sobretudo em Homero e Platão. Mas foi através da obra de Santo Agostinho, Da doutrina cristã, livro $V$, escrita em torno 426 d.C., que a hermenêutica torna-se mais amplamente conhecida como teoria da interpretação, e tem como significado principal confessar, pressagiar, elucidar, explicar etc.

Outras associações podem ser encontradas na mitologia grega, mais especificamente a Hermes, um "deus intérprete", alado, considerado o mensageiro dos deuses, pelo dom de abrir coisas fechadas, interpretar os desejos dos outros, desvendar significados, isto é, trazer à luz tudo 
aquilo que estava obscurecido. Assim, ele tinha o poder de traduzir o que a mente humana não compreendesse, para que as coisas do mundo pudessem ser entendidas.

Mais tarde, já no século XVIII, acredita-se que Friedrich Daniel Ernst Schleiermacher foi um dos primeiros a aproximar a hermenêutica da filosofia, num projeto universal que se baseia na noção de compreensão. Certamente, na sequência, outros filósofos se dedicaram a esse estudo, sobretudo Martin Heidegger. Este último, em sua análise da compreensão, diz que toda compreensão apresenta uma "estrutura circular", isto é, toda interpretação, para produzir compreensão, deve já ter compreendido o que vai interpretar. Por estrutura circular entende-se um tipo de compreensão que se move numa dialética entre pré-compreensão e compreensão da coisa, em um acontecimento que progride em forma de espiral, na medida em que um elemento pressupõe outro e ao mesmo tempo faz com que ele vá adiante. E é através dessa estrutura que Heidegger (1987) irá discorrer sobre a origem da obra de arte, como veremos a seguir.

The origin of the work of art (1987) [A origem da obra de arte], título de um dos ensaios mais conhecidos do filósofo alemão Martin Heidegger, iniciado entre 1935 e 1937, revisado para publicação em 1950 e mais tarde publicado em 1960, resulta de uma série de conferências proferidas por esse filósofo, em Zurique e em Frankfurt, na década de 1930. Inicialmente voltado para a essência da obra de arte, na sequência ancorou-se na interrogação do significado de uma "coisa", tema de suas primeiras conferências sobre a noção de arte. Profundamente influenciado por Edmund Husserl, de quem foi assistente após a Primeira Guerra Mundial, seu método pode ser classificado como fenomenológico e hermenêutico, conceitos que visam ao desvelamento do oculto.

Neste ensaio, Heidegger (1987) observa que todos os trabalhos de arte possuem um caráter de "coisidade", não obstante ser claro que arte não é uma mera coisa, sua insistência está em apresentar a diferença existente entre trabalhos de arte e tipos de objetos, de equipamentos que possuem uma função. Ao usar os termos terra e mundo, intrínsecos ao seu vocabulário, esse filósofo se refere ao que é chamado de natureza e história da 
espécie humana, respectivamente. Esses dois espaços são diferentes em seu conteúdo essencial, visto que os trabalhos de arte possuem um lugar especial entre terra e mundo, pois a arte pertence a esses dois campos, simultaneamente. Ao mesmo tempo em que a arte não é como a pedra nem plantas da terra, ela também não é exatamente um tipo de equipamento, de coisas associadas ao mundo. A arte, por conseguinte, se situa num espaço onde a terra e o mundo compartilham um relacionamento de simbiose, isto é, quando trabalhos de arte expõem entidades, eles trazem, à nossa atenção, a reunião da terra com o mundo.

Estimado como um dos expoentes da fenomenologia, esse filósofo trata também da relação entre o ser e as coisas e a maneira pela qual elas se tornam coisidades, a partir do lugar que ocupam. $\mathrm{O}$ espaço confere às coisas seus significados.

Como um dos principais assuntos deste livro, a matéria, o espaço e o tempo nas artes visuais, elegemos alguns trechos dessa obra para nos ajudar a pensar sobre a natureza da arte nesse contexto. Mas admitimos que o percurso é longo, quando se trata de arte, desde o seu processo criativo à sua recepção. Um percurso não linear, permeado por incertezas, e sem conclusões definitivas. Desse modo, para percorrer esse caminho, devemos manter a noção de que inexiste um início e fim determinados.

Iniciamos pelo conceito de "origem" que, segundo Heidegger (1987, p. 258), significa aquilo de onde e através do que algo é o que ele é, e como ele é, ou seja, originário de algo, a proveniência de sua essência. A partir dessa compreensão, Heidegger entende que, se o "originário da obra de arte pergunta pela proveniência de sua essência, a obra surge a partir da atividade do artista, [...] o artista é a origem da obra, e a obra, por sua vez, a origem do artista. Nenhum é sem o outro". O que nos leva a perceber que o conceito de origem da arte envolve diretamente tanto a obra como o artista, pois o mundo do artista não apenas se faz presente na obra, mas dela faz parte.

A arte torna-se, deste modo, uma força que usa o criador para os seus próprios propósitos, do mesmo modo que o trabalho resultante deve ser considerado no contexto do mundo em que não existe sem a existência de 
seu artista. A concepção de círculo hermenêutico, discutida por Heidegger (1987, p. 259), é paradoxal, ou seja, em qualquer trabalho, sem o entendimento do todo, não se pode compreender plenamente as partes individuais, mas, também, sem o entendimento das partes, não se pode compreender o todo. Trata-se, deste modo, de uma relação de cumplicidade e de um processo que envolve um constante pensar. Para este filósofo, "[...] pensar é uma habilidade". Mas como podemos definir melhor essa sua descrição? Se nesse círculo, para descobrir a natureza da arte que prevalece na obra, devemos nos voltar para a própria obra e perguntar como e o que ela realmente é - o que esse filósofo denomina de círculo?

De acordo com Heidegger (1987), este círculo é virtuoso, e reconhecer a circularidade é um momento de verdade, não um problema lógico. Assim, não se trata de evitar o círculo, mas de como interrompê-lo e aprender a pensar de forma diferente. Como sua intenção é exercitar o pensar, antes de ver um objeto como arte, alguns procedimentos devem ser seguidos. Primeiro, para definir se um trabalho é ou não é arte, é necessário determinar o que vai ser examinado, isto é, identificar o que essencialmente existe em uma obra. Mas, para isso, já devemos distinguir os objetos que são trabalhos de arte, das meras coisas, e ao saber fazer essa distinção, está estabelecido o reconhecimento do que é arte. É justamente esse processo investigativo que se move de uma forma que Heidegger (1987) denomina de pensamento circular. Como um dos fundadores da desconstrução, levada adiante por Jacques Derrida (1979), todos os conceitos devem ser analisados à luz de uma multiplicidade de interpretações, rompendo com o pensamento único. Como exemplos principais desse conceito, Heidegger (1987) usa a pintura Um par de sapatos, de Vincent van Gogh, e um templo grego.

Observemos primeiramente como Heidegger (1987) ilumina inúmeras especulações por meio da pintura de Van Gogh, Um par de sapatos (1888). Para ele, na sua variedade, os sapatos são usados para dançar, outros para caminhar, uns são feitos de couro, costurados, presos por pregos etc. Todas essas descrições apenas nos indicam o que já sabemos sobre esse objeto, ou esse equipamento, sapatos. Nesse sentido, o que sabemos 
são as características e suas funções, mas quanto ao processo de uso dos equipamentos - para que eles servem? Examinemos a descrição:

Da escura abertura do gasto interior dos sapatos a fadiga dos passos do trabalho olha firmemente. No peso denso e firme dos sapatos se acumula a do lento caminhar através dos alongados e sempre mesmos sulcos do campo, sobre o qual sopra um vento áspero e contínuo. No couro está a umidade e a fartura do solo. Sob as solas insinua-se a solidão do caminho do campo em meio à noite que vem caindo. Nos sapatos vibra o apelo silencioso da Terra, sua calma doação do grão amadurecente e o não esclarecido recusar-se do desolado inculto terreno do campo de inverno. Através deste equipamento perpassa a aflição sem queixa pela certeza do pão, a alegria sem palavras da renovada superação da necessidade, o tremor diante do anúncio do nascimento e o calafrio diante da ameaça da morte. À Terra pertence este utensílio e no Mundo da camponesa está ele abrigado. A partir deste pertencer que abriga, o próprio utensílio surge para seu repousar em si. (HEIDEGGER, 1987, p. 261, tradução nossa)

Como podemos observar, na citação acima, todas as especificidades destacadas no par de sapatos da camponesa só são definidas a partir do quadro de Van Gogh. Para a camponesa, o ser-sapato consiste na sua serventia, na função que ele desempenha, nada mais. Contudo, o ser do equipamento somente poderá ser encontrado fora de sua função, ou seja, fora de uma descrição e comentário de um utensílio-sapato realmente existente; mas apenas através do fato de que nos colocamos diante do quadro de Van Gogh. Esse pintor através de seus olhos, e na proximidade da obra que ele realizou, nos coloca repentinamente em outro lugar, diferente do que habitualmente costumávamos estar. No caso da pintura de Van Gogh, é como se a não-utilidade tivesse se associado à arte para provocar uma contemplação. Nesse caso, o ser real dos sapatos e o equipamento pertencem à terra (natureza) e é protegido no mundo da mulher camponesa. A arte, para Heidegger (1987), é uma criação contínua tanto 
do artista como do observador, o que, de uma certa forma, coincide com o objetivo de Van Gogh, ou seja, devemos exagerar o essencial e deixar o óbvio vago.

Na pintura de Van Gogh, os mesmos sapatos se apresentam à guisa de uma interpretação do mundo-objeto ausente; o pisar, caminhar, calçar, os sapatos gastos durante esse ser em ação. Van Gogh desvela o equipamento - sapatos-, através da entidade que emerge no descobrimento de seu ser, por meio da mediação da obra de arte, que faz com que todo o mundo ausente e a terra se revelem em torno dela.

No entanto, a explicação mais plausível ressalta assuntos que ganham relevância, tais como a distinção entre arte e outras "coisas", uma análise de ordem cultural que assegura algumas das fundações da arte moderna na expressão do ser em substituição à valorização da pura forma. Para tal compreensão e distinção, Heidegger (1987) explica a responsabilidade do observador em considerar a variedade de perguntas sobre os sapatos, que vão além de sua constituição formal, material e da maneira pela qual eles são feitos. E para outorgar a esse objeto (coisa - sapato) um determinado significado, é necessário percorrer um caminho sempre em busca de outros significados, sem quaisquer propósitos de atingir uma conclusão final.

“Todas as obras têm este caráter de coisa. O que seriam elas sem isso?"interroga Heidegger. (1987, p. 259-260, tradução nossa) Trata-se de um universo muito amplo pelo qual a obra perpassa de coisa à obra de arte. Observemos sua proposição:

Precisamos considerar as obras como elas se apresentam àqueles que as vivenciam e fruem. Mas também a tão evocada vivência estética não passa sem o caráter de coisa da obra de arte. Há pedra na obra arquitetônica. Há madeira na escultura. Há cor na pintura. Há som na obra de linguagem. Há sonoridade na obra musical. O caráter de coisa é tão irremovível na obra de arte que, ao contrário, seria melhor dizer: o monumento está na pedra, a escultura está na madeira. A pintura está na cor. A obra de linguagem está na fala. A obra musical está na sonoridade. Responder-se-ia que isso é evidente. (HEIDEGGER, 1987, p. 259-260, tradução nossa) 
Nesse sentido a obra é "uma coisa fabricada, [...] allo agoreuei: ela é alegoria”, existe algo que aparece junto àquilo de que ela foi produzida, que adere, manifesta outra coisa, palavra que em grego significa symballein (símbolo), fazendo com que ela seja constituída por "alegoria e símbolo, [...] que fornecem o enquadramento conceitual da noção pela qual a arte sempre esteve caracterizada”. (HEIDEGGER, 1987, p. 260, tradução nossa) Quanto a esse outro elemento que adere à obra, ser, ao mesmo tempo, considerado parte da sua constituição física, sua parte artesanal, é uma ideação onde gravitam certas especulações cujas respostas permanecem em aberto, visto que, fundamentalmente, é preciso entender que na filosofia heideggeriana, a essência, principalmente a essência humana (o ser-aí) se reproduz em mostrar no ente o ser que em si se desvela.

Quanto ao templo, segundo exemplo escolhido por Heidegger (1987), nele o mundo se manifesta com o foco da cultura grega, mas a ordem aí estabelecida também trabalha para acentuar a tensão entre a natureza e o mundo, uma nova perspectiva que eventualmente pode ser alcançada, e que se dá através do tempo.

Uma construção, um templo grego, não retrata nada. Ela simplesmente se ergue no meio de rochas escarpadas de um vale. A construção envolve a figura do deus e neste velamento a deixa projetar-se no âmbito do recinto sagrado através do pórtico aberto. Pela significação do templo o deus se faz presente. Essa presença do deus em si é a extensão e delimitação do recinto como um recinto sagrado. (HEIDEGGER, 1987, p. 267, tradução nossa)

Para que o templo seja sagrado é necessário que haja uma devoção, algo que adere à construção, que faz com que o templo seja algo mais do que uma construção. Como obra arquitetônica, resiste à tempestade que se abate furiosamente sobre ela e mostra, deste modo, a própria tempestade em sua força.

Heidegger (1987, p. 268) descreve os fenômenos naturais, como o passar dos dias, o entorno do templo com vista para o mar, como um cenário 
natural, onde se descortinam o brilho e a luminosidade do rochedo banhado pela luz do sol do dia e a escuridão da noite, a árvore e a grama, a águia e o touro, a serpente e o grilo que se apresentam na sua totalidade, como eles realmente são. A esse emergir e elevação, os gregos chamam de phusis, o que limpa e ilumina, bem como o que o homem designa de sua moradia. A isso, Heidegger (1987) denomina terra, natureza, tudo que eleva e abriga sem violência. Ao exemplificar o templo como um lugar que permite que o deus habite nesse espaço e ali possa ser venerado, esse filósofo fala sobre o ser-obra, que significa: instalar um mundo. E quando uma obra é produzida a partir deste ou daquele material - pedra, madeira, bronze, cor, língua, som - também se diz que ela foi elaborada com esse material.

Mas, assim como a obra exige uma instalação, no sentido do erigir conato e glorificante, porque o ser-obra da obra consiste em uma instalação de mundo, do mesmo modo torna-se necessária a elaboração, porque o ser-obra da obra tem ele mesmo o caráter da elaboração. A obra como obra é fabricada em sua essência. Mas o que a obra elabora, só experienciamos se acompanharmos o que se apresenta como o mais evidente e é denominado, habitualmente, a elaboração de obras, o seu processo de construção.

Para Heidegger (1987, p. 267), quando uma obra é colocada numa coleção ou apresentada numa exposição, diz-se que foi instalada. Este instalar, para ele, é essencialmente diferente da instalação no sentido da construção de uma obra arquitetônica, do erigir uma estátua e da apresentação da tragédia na celebração da festa. Esta instalação é o erigir como que consagrar e glorificar. Instalar não significa um mero colocar. Consagrar significa tornar sagrado, no sentido de que, no edificar como obra, o sagrado se abre como sagrado e o deus é chamado para o aberto de sua presença.

Heidegger (1987) explica a essência da arte em termos dos conceitos de ser e verdade, ao argumentar que a arte não é a única maneira de expressar o elemento de verdade em uma cultura, mas o meio de criar essa verdade, fornecendo uma espécie de trampolim, daquilo que algo é para aquilo que pode ser revelado. Nessa concepção, as obras de arte não são 
meramente representações da maneira pela qual as coisas são, mas do que elas realmente produzem por meio de um entendimento compartilhado por uma comunidade.

Diante das palavras de Heidegger (1987), pudemos acompanhar um dos mais brilhantes textos sobre a natureza da arte. Apesar de complexo, pelo seu caráter hermenêutico e desconstrutivista - próprio da filosofia heideggeriana -, esse filósofo nos faz refletir sobre conceitos que estão impregnados e invisíveis na obra de arte. Ao dizer que um quadro não é uma "coisa", Heidegger (1987), assertivamente, afirma que a obra é completamente oposta a tudo que chamamos de "coisas" no nosso mundo. Essa diferença está, em primeiro lugar, em relação à "função", isto é, um quadro não tem uma função no sentido instrumental, ele não é um equipamento para ser usado.

Nesse ensaio, Heidegger (1987) fala sobre as implicações da representação e a poética da obra à luz de um pensar, pois tudo que ultrapassa a "coisidade", instaura a dimensão da obra de arte. Observemos que no seu vocabulário, a palavra dasein, a manifestação do ser-no-mundo, pode ser entendida como "o ser-aí", ou seja, trata-se do lugar onde emerge a questão do ser, o lugar de sua manifestação. Diferentemente de uma compreensão tradicional do ser fundamento, isto é, "o ser é", devemos entender o "darse ser". Como filho da corrente existencialista de Edmund Husserl, seu interesse inicial está em Ser e tempo, título da obra que não concluiu.

Segundo Heidegger (1987), quando o ser passa a um ser possibilidade e não fundamento, tem-se a consciência de que não há sujeito sem mundo, assim como não há homem sem dasein. Por estarmos inseridos no mundo e dele fazermos parte integrante, o dasein é um ser-no-mundo, juntamente a outros, um ser com os outros, no sentido de alteridade. Esse entendimento vem acompanhado da noção de tempo, ao que Heidegger (1987) atribui um ser constituído por um tempo presente, passado e futuro, por conseguinte, o ser, o tempo, passa de meramente "ser" para "dar-se" no tempo.

O ser e o tempo se estabelecem num processo de apropriação que manifesta no homem o ser, alétheia, o desvelamento. 


\title{
Espaço - Tempo - Lugar
}

\begin{abstract}
$\bigcirc$ que o intelecto restaura em nós sob o nome de passado não é o passado. Na realidade, logo que cada hora de uma vida se esvai, ele se incorpora em algum objeto material, como fazem as almas dos mortos em certas histórias populares, e aí se esconde. Aí permanece cativo, cativo eternamente, a menos que devamos reconhecer o que nele se encontra, chamá-lo por seu nome, e colocá-lo em liberdade.

Marcel Proust, 1905
\end{abstract}

O estudo sobre o espaço e o tempo vem desde a Grécia antiga, e é um dos temas mais recursivos na nossa atualidade, em decorrência das novas aplicações de tecnologia em diversas áreas. Para as artes visuais, a inclusão de suportes digitais traz à tona investigações que têm dado origem a uma diversidade de teorias e conceitos que, neste livro, dialogam desde os antigos gregos, passando por Charles Peirce, às mais recentes pesquisas científicas deste milênio. E esse estudo se faz necessário para entendermos como as técnicas tradicionais migraram para outros espaços, bem como os diversos temas abordados que estão direta ou indiretamente ligados a esses conceitos. Portanto, falar sobre espaço e lugar, seja através do processo que a arte passou a configurar, seja pelos inúmeros conteúdos que encontram nesse assunto conforto emocional e psicológico, é, sem dúvida, um desafio importante para uma melhor compreensão dos enfoques que povoam as obras de inúmeros artistas.

Iniciamos com Borges (2006, p. 9), que entende que "o movimento, ocupação de diferentes lugares em diferentes momentos, é inconcebível sem tempo: também é a imobilidade, ocupação de um mesmo lugar em diferentes momentos do tempo". Borges (2006, p. 14) recorre a Plotino para exemplificar a noção que esses conceitos tinham na antiguidade.

Toda coisa no céu inteligível também é céu, e ali a terra é céu, como também os animais, as plantas, os verões e o mar têm por espetáculo um mundo que não foi gerado. Cada um se vê nos outros. Não há nesse reino coisa que não seja diáfana. Nada é impenetrável, nada 
é opaco e a luz encontra a luz. Todos estão em toda a parte, e tudo é tudo. Cada coisa é todas as coisas. $\bigcirc$ sol é todas as estrelas, e cada estrela é todas as estrelas e o sol. Ninguém caminha ali como sobre uma terra estranha.

A palavras de Plotino são para Borges (2006, p. 33) como um céu limítrofe "não inteiramente emancipado do número e do espaço". Nessa passagem do quinto livro, Plotino

quer exortar à contemplação da eternidade, ao mundo das forças universais", e tais afirmações são um repertório seleto, visto que o número de momentos humanos não é infinito. Os essenciais - os de sofrimento e prazer físico, os da aproximação do sono, os da audição de uma música, os de muita intensidade ou muito fastio são ainda impessoais.

Sem uma resposta para o tempo, Borges (2006, p. 33) entende que nada poderá deter "a palavra final sobre a verdade do ser, nenhuma [palavra] esgota a visão problemática do homem e seu destino, bem como radicaliza o esforço de se refutar o tempo". Para esse escritor, o tempo não existiria, seria apenas uma vaga e ilusória convenção humana, e, nesse sentido, encontramos na sua obra metáforas do tempo, do espelho, do eco e do labirinto. Inspirado nos pré-socráticos, Borges (2006), através da água e do rio, fala de um tempo em constante devir.

Já Delaney (2002), nos informa como Peirce entendia o espaço e o tempo:

A via de acesso de Peirce à continuidade do espaço é por meio dos paradoxos de Zenão; ele argumenta que os paradoxos surgem de uma concepção inadequada da continuidade radical do espaço. Dizemos que o espaço é contínuo, mas continuamos a pensá-lo como um agregado de unidades discretas. Na concepção de Aquiles, passando por uma série determinada de segmentos 
de linha, é presumida uma métrica em cujos termos a posição de Aquiles é sucessivamente definida. Mas visto que uma métrica é um sistema de valores discretos, ela introduz a ficção de que há pontos discretos sobre a linha correspondendo aos seus valores. É essa ficção que gera os paradoxos, já que solicita a perspectiva segundo a qual o espaço é um contínuo composto de partes últimas: "todos os argumentos de Zenão dependem de supor que um contínuo tem partes últimas - mas um contínuo é precisamente que cada parte dele tem partes no mesmo sentido". (DELANEY, 2002, p. 11)

O outro lado da tese do prosseguimento do tempo é a continuidade da consciência, já que o argumento de que o tempo é contínuo é um assunto para o efeito de que "estamos imediatamente cônscios através de um intervalo infinitesimal de tempo". (CP 6.110) De fato, Peirce (CP 6.182) sustenta que percebemos diretamente a continuidade da consciência. Ao falar sobre esse assunto, não podemos deixar de recordar que a experiência cotidiana - buscando afirmar o que sobre ela é verdadeiro -, encontra fundamento no ramo das ciências da filosofia peirciana. Para Peirce, tempo e espaço são contínuos porque incorporam condições de possibilidade, e o possível é geral, e continuidade e generalidade são dois nomes para a mesma ausência de distinção de individuais. (CP 4.172) Como um filósofo que extingue o dualismo, sobretudo mente-matéria, Peirce propõe pensar a totalidade das coisas num fluxo contínuo e evolucionário, o que ele denomina de sinequismo.

Segundo Foucault (1986), a grande obsessão do século XIX foi a história, cujo interesse estava voltado para a cidade moderna, o desenvolvimento industrial e uma crença em recursos mitológicos. Já no século $X X$, diferentemente desses interesses, as atenções estavam mais voltadas para o espaço, com todas as suas características, que incluem a simultaneidade, a justaposição, a concepção do perto e do distante, do lado-a-lado, do difundido etc.

Durante a Idade Média, havia um conjunto de hierarquias de lugares, a exemplo dos lugares sagrados e profanos; protegidos, abertos e expos- 
tos; lugares urbanos e lugares rurais, lugares que faziam parte da vida do homem. Já na teoria da cosmologia, os espaços supercelestiais apareciam em oposição ao celestial, enquanto o celestial em oposição ao terrestre. Havia lugares onde as coisas eram postas e, ao serem deslocadas, elas sempre buscavam uma estabilidade no seu chão natural, pois aquele não era o seu lugar de origem. Era esta a hierarquia completa, esta oposição, esta interseção de lugares que constituíam o que muito grosseiramente poderia ser chamado de espaço medieval: o espaço da localização. $E$ esse espaço da localização, introduzido primeiramente por Galileu, foi concebido como um espaço infinitamente aberto.

Mais tarde, com a dissolução do lugar na Idade Média, o lugar de uma coisa passou a ser entendido como um ponto em seu movimento. Em outras palavras, começando com Galileu e o século XVII, a extensão foi substituída pela localização.

Para Foucault (1986), o espaço contemporâneo ainda possui características próprias de outras épocas, como algo que ainda não acompanhou os avanços científicos e tecnológicos do século XX. Alguns exemplos dados são as oposições presentes na vida das pessoas, como as divisões espaciais estabelecidas entre privado versus público, família versus social, cultural versus útil, espaço versus trabalho. Além de dicotômicas, as divisões apontam para uma presença invisível do sagrado. Esses conceitos não comungam com a nossa heterogeneidade espacial, permeada por sentimentos, sonhos, paixões, que preenchem nossas vidas, dentro de um contínuo jogo de espaços e relações sígnicas.

Santaella (2007), dedica um capítulo especial ao espaço neste novo milênio, em Linguagens líquidas na era da mobilidade. Como o próprio título já diz e sugere, as linguagens líquidas deslizam de uns para outros espaços, sobrepõem-se, complementam-se, confraternizam-se, unem-se e se separam, entrecruzam-se, tornaram-se leves, perambulantes.

Nesse contexto, o fixo perde sua estabilidade que a força de gravidade dos suportes lhe emprestava, para tornar-se aparições, presenças fugidias que emergem e desaparecem ao toque delicado da ponta de nossos 
dedos em minúsculas teclas. São os aparelhos digitais, tais como telefones celulares, computadores de alta geração, rastreadores etc.

Essas presenças e representações fugidias sobrevoam os diversos espaços, a velocidades que competem com a da luz; elas são tão voláteis que um dos grandes problemas atuais encontra-se nas novas estratégias de documentação que devem ser encontradas quando os meios de estocagem tornam-se obsoletos em intervalos de tempo cada vez mais curtos. A era digital móvel dos aparelhos minúsculos e eficientes desobstrui os tradicionais obstáculos materiais que bloqueavam o processo de semiose, dos fluxos dos signos e das trocas de informação. Os espaços tornaram-se mais elásticos.

Santaella (2007) aborda o espaço desde sua origem e conceitos, passando pelas suas classificações, das quais selecionamos as que mais se aproximam do nosso assunto, ou seja, as informações sobre a origem do espaço e sobre o espaço na experiência humana, com suas respectivas divisões.

De acordo com Santaella (2007, p. 158-159), etimologicamente, o espaço possui vários significados; para Platão, o espaço chama-se chora, antes do termo topos e na Grécia antiga esse termo também é denominado de caos, bem como vazio. "As metáforas do Timaeus são obscuras, mas delas se pode extrair que Platão pensou sobre o espaço como um recipiente e a matéria nesse recipiente como um mero espaço vazio limitado por superfícies geométricas". [Definição refutada por Aristóteles, que tentou contornar essa dificuldade ao tratar o conceito de espaço como lugar, topos, ou seja,] "a fronteira interior daquilo que contém a fronteira adjacente de um corpo nele contido. Sua intenção parece ter sido definir lugar em relação ao cosmos como um todo" [...]. [A palavra cosmos foi] "enunciada pela primeira vez por Homero [...] como um princípio do universo no seu todo", e espaço e tempo eram traços da natureza. Vejamos ainda as considerações dessa autora, a seguir:

No contexto dos paradoxos de Zenon, ainda na sua física, Aristóteles reclamava por um paradoxo comum a espaço e tempo, sem o que não poderia haver uma concepção de movimento. Para ele, o 
movimento, kinesis, em um sentido amplo, separava o animado do inanimado, e sem a kinesis não haveria alma, consciência ou intuição. [...] $\bigcirc$ espaço da perspectiva retilínea padrão, utilizado na representação visual, foi também uma criação do século XVI. Essa perspectiva pretendia criar, na bidimensionalidade mimética, a ilusão da tridimensionalidade, o que era conseguido pelo recurso da introdução, na estrutura central, de um ponto de fuga para o infinito. Do espaço da perspectiva veio a presunção de que esse é o único espaço da visão ótica verdadeira. Entretanto, a história da arte moderna, a partir de Cézanne (1839-1906), está povoada de exemplos de recriações de espaço pictórico em oposição à pretendida hegemonia da perspectiva monocular. (SANTAELLA, 2007, p. 160-161)

Falar em "realidade" - mesmo que seja aquilo que ingenuamente entendemos por realidade - nos conduz para o espaço da percepção e das experiências humanas, nas quais o conceito de espaço passa a ter um estatuto psíquico, social e histórico que apresenta uma multiplicidade transbordante de facetas. (SANTAELLA, 2007, p. 164)

Em relação ao espaço na experiência humana, Santaella (2007), recorre a Edward Relph (1976), ao revelar que:

O espaço que experenciamos [...] é o espaço do céu, ou do mar, ou da paisagem, ou de uma cidade vista de um edifício alto, o espaço construído das ruas, dos prédios vistos de fora ou experienciados no seu interior, o espaço dos mapas, dos planos, cosmografias e geometrias, espaç̧os interestelares, o espaço possuído pelos objetos ou reclamados pelos países ou ainda o espaço devotado aos deuses. [...] O espaço nos oferece uma variedade de formas e de relações entre espaço e lugar em que os lugares não podem ser separados de seu contexto de experiência. (RELPH, 1976 apud SANTAELLA, 2007, p. 164) 
Partilhando da visão de Relph (1976), podemos afirmar que o mundovivido cultural em que passamos a maior parte da nossa vida diária está repleto de signos, não estando isolado do mundo sociocultural, que, por sua vez, possui e está permeado de intersubjetividade. Trata-se de um assunto complexo que não pode ser esgotado em apenas poucas palavras. Para Relph (1976), o mundo-vivido não é óbvio, e é preciso que seus significados sejam descobertos. Embora seja inatingível e difuso, o contínuo da nossa vivência de espaço, como continua Santaella (2007, p. 171), a seguir, depende do sistema de orientação geral que vem do corpo inteiro, o espaço perceptivo, que:

É um campo de encontros afetivos e emocionais com os espaços da terra, do céu, das cercanias do mar, da densidade das matas e também com os espaços construídos pelo ser humano. [...] $\bigcirc$ azul do céu, por exemplo, não é apenas a luz do azul sem fim, mas uma fronteira entre o visível e o invisível; o vazio do deserto é também paisagem alucinada de um oásis; a areia em que deitamos ao sol, é, acima de tudo, uma experiência de intimidade plácida e feliz com o calor e a maciez que a natureza nos traz de presente. Enfim, reflexos, sombras, brilhos, neblinas, no lusco-fusco de suas danças sutis, ao atraírem nossos sentimentos, exaltam nossas fantasias.

O espaço de existência corresponde aos espaços definidos e construídos pela cultura, que possuem as marcas deixadas sobre a terra pelo homem. São espaços que estão sempre potencializados pela experiência. (SANTAELLA, 2007, p. 168) Além disso, os espaços, também na sua diversidade de classificações, possuem destaque na geografia, âmbito considerado por Santaella (2007, p. 169) como um dos mais amplos:

[...] que significados são dados a nações, continentes e regiões que vão além da nossa experiência direta e têm, portanto, um caráter cognitivo. $\bigcirc$ espaço seguinte é o espaço das paisagens por ser quase inteiramente um espaço construído, resultante dos esforços 
dos propósitos humanos. A seguir, vêm os espaços da rua, a base de nossa experiência com a cidade. Depois das ruas vem o espaço da casa, ponto de referência nuclear da existência humana. É por isso que, para Bachelard, "todos os espaços realmente habitáveis trazem a essência da noção de lar". Por fim, há o nível dos objetos, de um lado, um espaço material no qual o valor dos objetos advém do significado de seus usos, e de outro, um espaço simbólico no qual os objetos representam outros espaços ou experiências, funcionando a rigor como signos. De fato, todos esses espaços compõem a tessitura de nossas experiências vivenciais. Evidentemente, eles não precisam estar efetivamente presentes todo o tempo, mas estão sempre potencialmente presentes. Como focos de intenção e de interesses e fontes de significação, esses espaços se constituem em um universo de apelo ilimitado aos estudos semióticos.

\section{Por sua vez, Norberg-Schulz considera que:}

O espaço orgânico integra o ser humano no seu ambiente natural; o espaço perceptivo é essencial para a sua identidade como pessoa; o espaço de existência o faz pertencer a uma totalidade social e cultural; o cognitivo significa que ele é capaz de integrar a experiência e o pensamento. (NORBERG-SCHULZ, 1971 apud SANTAELLA, 2007, p. 171)

Após um detalhado percurso sobre o assunto, Santaella (2007, p. 172) descreve as noções de espaço na nossa atualidade, e, quanto à experiência da paisagem cotidiana dos centros urbanos, confirma que:

Continuamente mutável, destituídas de centros e bordas claramente definidos, as megacidades desafiam quaisquer sentidos de ordem. Disso resulta a natureza protéica tanto das identidades dos habitantes quanto das fronteiras dessas paisagens. Caindo por terra a visão tradicional de que cada indivíduo deveria apresentar uma identidade estável e constante por toda a vida, o habitante 
polimorfo desses ambientes muda sua identidade ao sabor dos acontecimentos, deslocando-se entre opções e alternativas que não raras vezes se frustram.

A mudança dos conceitos tradicionais sobre o espaço, notadamente presentes neste início de século, estava sendo pressentida em insinuações nas obras de Edgar Poe, Baudelaire e Walter Benjamin, e mais tarde, em Relph (1976). Segundo Santaella, este autor

[...] já estava sismografando as vibrações que adviriam sob efeito do capitalismo globalizado. Nessa medida, ele antecipou muitos dos temas que vêm sendo discutidos, [...] prognosticou o relevo progressivo que a questão do espaço passaria a adquirir das últimas décadas para cá. Tanto é que seu livro tem um título bem similar Lugar não lugar - ao do livro Não-lugares, que Marc Augé publicou em 1992. (RELPH, 1976 apud SANTAELLA, 2007, p. 172)

A essas classificações de espaço, Santaella adiciona ainda outros tipos de espaço, relacionados ao mundo contemporâneo - caracterizado pela impermanência, efemeridade, mobilidade - e derivados das conquistas tecnológicas. Próprios do processo de globalização, que vem desestabilizando a noção do espaço fixo e imutável, constituem os lugares/ não-lugares, os espaços ciber e os espaços de hipermobilidade. Contudo, apesar de todas essas mudanças no conceito de espaço, nas artes visuais, como nos diz Santaella (2007, p. 191-192): "O corpo material do signo - o som, as tintas, a grafia - não pode existir sem o suporte em que se plasma. Não se pode separar o dançarino da dança. [...] Sem um suporte - parede, tecido ou madeira -, as tintas não poderiam criar linhas, formas, volumes, luzes e sombras".

Desse modo, quaisquer que sejam as linguagens visuais, o que permanecerá dando sentido a elas é o seu caráter sígnico e a necessidade de um suporte sensível para que o artista possa materializar suas ideias. 
Para finalizar nossas colocações, escolhemos Lippard (1997a), que aborda o conceito de lugar de uma maneira bastante peculiar, e que em muito poderá contribuir para futuras análises de artistas que fazem essa ponte em suas obras. Lippard (1997a, p. 7) inicia com a seguinte declaração:

Um lugar para mim é um local de desejo. Os lugares influenciaram mais minha vida, do que as pessoas. Eu me aproximo mais rapidamente a espaços do que às pessoas. Posso me guiar por uma paisagem e nitidamente me imaginar desagregando-me numa cabana de mineração, nessa fazenda de Saltwater, nessa casa pequena de varanda. Posso me imaginar caminhando por uma vizinhança com quintais despercebidos. Posso sentir-me, cinestesicamente, como seria caminhar durante horas por uma paisagem "vazia" vasta que eu precipito-me dentro de um carro - ou debaixo das texturas dos pés, do pó ascendente, da maneira que os músculos se contraem numa colina, dos ritmos de andar, do sentir o sol ou a névoa atrás do meu pescoço. Os lugares suportam os registros de culturas híbridas, histórias híbridas que devem ser tecidas numa nova corrente principal. São nossos "fundos" de casa em cada sentido. (tradução nossa)

Locus, palavra latina que significa lugar, possui diversos significados, desde a psicologia à genética, com aplicação ao estudo do DNA, genomas, uma posição fixa do cromossoma. Todos esses termos podem ser interpretados nesta declaração, e estar presentes neste livro.

Esse lugar de desejo, para Lippard (1997a), é também uma lembrança sempre presente de sua infância, de lugares onde são construídas identidades, os próprios desejos em todos os seus sentidos, um lugar é uma carga de forte emoção pessoal e de consideráveis valores, ambiental e cultural. Lure, sedução, fascinação, atração, desejo, um relato pessoal que constrói um discurso rico em questões que envolvem a nossa atualidade, como proteção ambiental, ecologia, perda de identidade, dentre outros assuntos afins. Sendo uma experiência autobiográfica, um relato experienciado, o tom do discurso de Lippard (1997a) proporciona um maior aprofundamento. Por conseguinte, o lugar é uma das questões mais atuais que afeta o ser 
humano, sua sobrevivência e a Terra como um todo, que Lippard (1997a, p. 7) declara ter investigado como um exercício de maturidade intelectual. São conceitos universais, e que afetam a humanidade:

Este processo - de tentar simplesmente dar valor a um lugar particular não apenas pelo forte valor emotivo que ele tem para mim, mas que eu acredito ser de um valor mais amplo regional e cultural - me dirigiu a esta meditação sobre lugar e pertencer. Como nós pessoalmente e culturalmente construímos espaços e lugares, como localizamos o próprio lugar e como negociamos essas reivindicações e usos que competem com nossa posse literal ou mediúnica desse lugar: estes são todos os aspectos que eu procurei tornar visíveis por um lugar onde interesses regionais e nacionais se manifestam, embora de uma maneira relativamente local. É minha visão em que uma parte de um valor cultural de um específico lugar individual se encontra em sua manifestação de interesses culturais mais amplos. [...] A maioria freqüentemente aplica o termo lugar ao próprio "local" - entrelaçado com memória pessoal, histórias conhecidas ou desconhecidas, marcas que fizeram na terra, que provoca e evoca. O lugar é latitudinal e longitudinal dentro do mapa da vida de uma pessoa. É temporal e espacial, pessoal e político. Uma situação cheia de histórias humanas e memórias, o lugar tem largura assim como profundidade. Está sobre conexões, o que o cerca, como ele foi criado, o que aconteceu e o que acontecerá aí. (tradução nossa)

"Todos os lugares existem em algum lugar entre a visão interior e exterior deles. Então, um entendimento, um lugar deve considerar ambos". (LIPPARD, 1997a, p. 33, tradução nossa) 



\section{4}

\section{ÍNDICES DE CONTEMPORANEIDADE NAS ARTES VISUAIS}

\section{Assinatura do Modernismo: primeiro conceito de Vanguarda}

Fineberg (1996) descreve o conceito de paradigma nas artes plásticas associado ao que ele denomina de assinatura do modernismo, através da obra de Gustave Courbet, pintor francês pertencente à escola Realista, no final da década de 1840, na França. Para Courbet, o Realismo era essencialmente a arte democrática. Quando passou a representar a vida dos camponeses com mensagens políticas, foi de encontro às ideias do imperador francês Luiz Napoleão e da pintura da época que estava voltada para a representação da natureza segundo os cânones vigentes, aos 
quais ele se opôs, intencionalmente, por meio de pinceladas espontâneas. Ao ser rejeitado no Salão Oficial de Paris (1855) - uma grande exposição pública anual -, esse pintor construiu um pavilhão perto desse espaço e ali expôs quarenta e quatro de suas pinturas, às quais ele chamou de realistas, fundando assim esse movimento. Esse fato causou insatisfação a muitos, por ser considerada uma nova estética da classe trabalhadora e por contrariar as formas visuais próprias daquele tempo. $O$ pensamento revolucionário e o rompimento com a arte considerada oficial foram itens principais no âmbito do Realismo, ao se tornar, então, realista, Coubert foi considerado por Fineberg (1996) o paradigma do artista moderno - dos artistas desse período que incluíram no seu vocabulário outras ideias. Esse rompimento se tornou um modelo de relação entre artista versus visual versus sociedade, o que mais tarde veio a ser conhecido como avant-garde, termo francês de aplicação, primeiramente militar, e que na arte relacionase àqueles que correm contra a normalização das forças tradicionais.

No final do século XVIII, o conceito de vanguarda evoluiu do contexto dos movimentos que dominaram a América e a Europa, e cada vez mais a introdução de novas ideias em debates passou a ser entendida como um veículo de progresso, o mecanismo da democracia, contribuindo, para tanto, não apenas a opinião pública, mas também as ideias do indivíduo. Se entendermos o resultado dessa ação como algo que só se tornou visível a partir do enfrentamento das limitações impostas pelas normas oficiais, podemos dizer que na arte as mudanças acontecem exatamente devido a essas limitações, ou seja, quando ocorre algo que não pode ser resolvido no âmbito do contexto dominante.

Diante desses argumentos, como e por que a arte se desenvolve, qual é, e se há uma natureza desse progresso, abordaremos alguns teóricos e historiadores da arte contemporânea que podem elucidar este assunto, iniciando com as considerações de Frijof Capra (1999), Johnathan Fineberg (1996), Kristine Stiles e Peter Selz (1996) e Thierry de Duve (1998). A aplicação do termo "paradigma" merece uma reflexão mais aprofundada, já que, para esses autores, as mudanças ocorridas na arte, ou seja, a substituição 
de regras e princípios, aconteceram, assim como na ciência, baseadas no rompimento de normas em busca do novo.

Nas duas citações, a seguir, Frijof Capra define o conceito de paradigma aplicado à ciência e à arte, com peculiaridade, a saber:

O progresso na arte pode ser entendido na maneira pela qual uma obra-prima proporciona uma nova descoberta na experiência humana, algo que não estava acessível à nossa experiência antes. [...] Se a arte está ligada à questão do paradigma científico, porém, a sua evolução é diferente da ciência. [...] E como resolver a discrepância entre ciência e arte? É sabido que a ciência busca quebrar as categorias, como as "coisas" e "formas", para repô-las, com o conhecimento comum que cobre todas as experiências. Mas isto é presunção. Nem todas as ciências juntas poderiam cobrir toda a experiência humana, nem poderão, tampouco, fornecer uma compreensão completa e definitiva da realidade. (CAPRA, 1999, p. 139)

Na ciência há progresso, você se move em direção a teorias cada vez mais abrangentes, precisas e poderosas, no sentido de poder de previsão. Isso é bastante característico da ciência. É claro que isso não está presente na arte. Você não pode dizer que Picasso é um aperfeiçoamento de Rubens, ou que Chagall é um aperfeiçoamento de algum pintor clássico. (CAPRA, 1999, p. 138-139)

Por outro lado, Stiles e Selz (1996), ao explicarem as mudanças e transformações na arte, retomam o conceito, elaborado por Thomas Samuel Kuhn (1962), de paradigm shift (mudança de paradigma), usado tanto por humanistas como por cientistas, para explicar como permutas, modificações e quebras nas fundações epistemológicas de uma determinada disciplina alteram suas práticas e crenças, tornando-se saltos revolucionários. Trata-se, conforme Kuhn (1962, p. 56), de "uma constelação de realizações - concepções, valores, técnicas etc. - compartilhada por uma comunidade científica e utilizada por essa comunidade para definir proble- 
mas e soluções legítimos". Deste modo, é de competência dos membros de uma comunidade de pesquisa estabelecer se uma determinada disciplina é científica ou não, através de um acordo comum.

Diante do exposto, a arte não pode participar desse acordo, visto que ela é a única que goza do que Charles Peirce (2005) denomina, com sua categoria de primeiridade, de pura liberdade. Em arte, não existe a interpretação verdadeira, não há acordo de opiniões, porque ela não possui um objeto externo real. Quando o objeto é arte, signo e objeto são um só; o objeto é mera referência do discurso gramatical. $O$ signo da arte, portanto, não passa pela verdade; apenas aponta para outros mundos possíveis, mundos próprios das ideias de cada artista. A ideia de semelhante é uma ideia de autoidentidade, signo e objeto são a mesma coisa. Mesmo em se tratando de uma pintura figurativa, quer o modelo exista ou não, o quadro representa a si mesmo; encerra qualidades; as categorias de expressão e de sentimento transcendem a própria representação segundo a semelhança. A arte, portanto, diferentemente da ciência, é um ícone; um signo que representa o seu objeto de tal modo que suas condições de significação como signo não dependem da existência desse seu objeto.

Deleuze e Guattari (1992, p. 216) nos oferecem outras definições complementares que contribuem para enriquecer as informações ora abordadas, a seguir:

Pintamos, esculpimos, compomos, escrevemos sensações. [...] E o sorriso sobre a tela é somente feito de cores, de traços, de sombra e de luz. Se a semelhança pode impregnar a obra de arte, é porque a sensação só remete a seu material [...] o sorriso do óleo, o gesto de terra cozida, o élan de metal, o acocorado de pedra romana e o elevado de pedra gótica. E o material é tão diverso em cada caso (o suporte da tela, o agente do pincel, ou da brocha, a cor no tubo), que é difícil dizer onde acaba e onde começa a sensação, de fato; a preparação da tela, o traço do pêlo do pincel fazem evidentemente parte da sensação, e muitas coisas antes de tudo isso. Como a sensação poderia conservar-se, sem um material capaz de durar, e, por mais certo que seja o tempo, este tempo é considerado como uma duração. 
De acordo com Deleuze e Guattari (1992, p. 213) “a arte conserva, e é a única coisa no mundo que se conserva. Conserva e se conserva em si (quid juris?), embora, de fato, não dure mais que seu suporte e seus materiais (quid facti?), pedra, tela, cor, química etc.". [E assim, podemos dizer que] "a obra de arte é um ser de sensações, e nada mais: ela existe em si".

Segundo Thierry de Duve (1998, p. 386), Thomas Kuhn (1962) não acreditava que pudesse existir um paradigma estético, e sim uma mudança do antes para o depois, isto é, uma visão retrospectiva do que isso impõe. Nesse contexto, a palavra retrospectiva não significa retroagir, mas a interpretação depois-do-fato, e isso não requer julgamento. Não se trata de uma crítica, nem na concepção greenbergiana nem kantiana - é uma concepção arqueológica -, no sentido que lhe deu Michel Foucault (1972), a qual rejeita as sínteses historicistas, as continuidades das grandes descrições históricas e a própria ideia de uma obra total. O seu fundamento encontrase na pesquisa de enunciados particulares em determinados discursos, por isso o método de Foucault (1972) se apoia em descontinuidades, diferenças e dispersões para tentar recuperar a episteme do passado.

\title{
O advento da Fotografia e sua relação com a Pintura
}

\author{
A visão de realidade imediata tornou-se uma orquídea no \\ campo da tecnologia. \\ Walter Benjamin, 1986a
}

Na Idade Média, os artistas abordaram o tema histórico, a narrativa do realismo, a verossimilhança, e todos os cientistas reivindicaram para si novos direitos de pensamento. Até o advento da fotografia, o homem acreditava que o mundo era uma coisa idílica, mas a partir dessa invenção tecnológica, várias são as considerações que surgem em uma visão semiótica, como sublinha Santaella (2007, p. 208): "antes do surgimento da tecnologia fotográfica, a grande metáfora da representação visual foi, durante séculos, a metáfora da janela. A pintura funcionava como uma janela para o mundo", e tinha como principal objetivo espelhar a realidade através da 
representação, mas devemos entender, assevera Santaella (2007, p. 211), que, no caso, "as representações funcionam como espelhos fiéis ou infiéis da realidade", ou seja, a partir "do século XIX a boa parte do século XX as concepções acerca das formas de representação da realidade (teatro, jornal, literatura e cinema documental) estavam marcadas pela idéia do espelhamento". (SANTAELLA, 2007, p. 208)

Ao entrarmos no verbete do dicionário de Flaubert - Le dictionnaire des idées reçues (1870) -, a definição para a palavra fotografia aparece como: "tornará a pintura obsoleta" (veja daguerreotype) e ao entrar na palavra daguerreotype (daguerreotipia), aparece: "tomará o lugar da pintura" (vide photography), descrição que irá coincidir com o pensamento de Walter Benjamin (1986a). Para esse autor, a fotografia teria um efeito verdadeiramente profundo sobre a arte, até uma extensão em que a pintura talvez desaparecesse, ao perder sua aura para a reprodução mecânica.

No ensaio $A$ obra de arte na era de sua reprodutibilidade técnica, primeiramente publicado em 1936 (um dos mais conhecidos e citados dos textos desse filósofo alemão), Walter Benjamin (1990) levanta considerações relevantes sobre a posição da pintura frente à reprodutibilidade técnica, do ponto de vista político e não meramente estético. As reflexões postas por Benjamin (1990) estão direcionadas à aura, presente nas obras originais, consideradas únicas, das sociedades tradicionais ou pré-modernas; nessas últimas, a aura estava condicionada ao sagrado, e mais tarde, nas sociedades capitalistas, à elevação da arte a um conceito de autenticidade. A aura é também entendida como sendo uma relação especial que uma obra possui, a partir do momento em que desempenha uma função ritual, ou torna-se um objeto que passa a ser considerado artístico, original e autêntico. Se por um lado a pintura sofre a perda de um espaço privilegiado, por outro, com o advento da fotografia, os artistas tornam-se livres. Como membro da Escola de Frankfurt, Walter Benjamin se destaca de seus colegas ao ver com otimismo a introdução dos múltiplos na arte, ou seja, a possibilidade de se conseguir várias imagens através de um negativo.

Berger (1987, p. 16) explica que a pintura antes da fotografia representava uma imagem única, em um só espaço de tempo; uma imagem que 
não podia ser apreendida mais de uma vez. É, portanto, nesse contexto que a câmara fotográfica mostrou que a noção de passagem do tempo era inseparável da experiência visual. Pois, antes, o homem acreditava que podia ver tudo; que o mundo possuía apenas um centro, noção inerente ao uso da perspectiva na pintura e no desenho. Ao trazer para os artistas um olhar ao mundo real descontínuo, a perspectiva deixa de ser necessária, já que a máquina fotográfica possibilitou uma visão das coisas através de ângulos até então inimagináveis. "Assim explico, de uma nova forma, o mundo por todos ignorado”, diz Dziga Verton (apud BERGER, 1987, p. 17), ao definir as peripécias, até então inesperadas, proporcionadas por essa nova máquina. Vejamos, a seguir, a continuação das palavras de Verton, ao descrever a noção de mobilidade da máquina:

Sou um olho. Um olho mecânico. Eu, a máquina, mostro-vos o mundo de um modo como só eu posso vê-lo. Liberto-me hoje e para sempre da imobilidade humana. Estou em constante movimento. Aproximo-me e afasto-me dos objetos. Rastejo debaixo deles. Movo-me colado à boca de um cavalo a correr. Caio e levanto-me juntamente com corpos que caem e se levantam. Isto sou eu, a máquina, manobrando entre movimentos caóticos, registrando um movimento após o outro, nas combinações mais complexas. Liberto os limites de tempo e de espaço, co-ordeno cada um e todos os pontos do Universo, onde quer que eu queira que eles se encontrem. $\bigcirc$ meu caminho conduz à criação de uma nova percepção do mundo. (VERTON, 1923 apud BERGER, 1987, p. 17, tradução nossa)

Essa era a sensação que o homem passou a experimentar ao ver pela primeira vez o mundo através das lentes. Enquanto a fotografia experimentava inúmeras maneiras de ver o mundo, a pintura, livre da sua antiga função, passa a representar a natureza conforme a vontade de cada artista. Assim, absorve e dilui o horizonte presente nas pinturas paisagísticas em linhas que se interceptam, cruzam-se, como se fosse um olhar a um espaço visto de cima. 
Para Berger (1987, p. 31), "originalmente as pinturas são silenciosas e fixas; isso tem o efeito de fechar o tempo da distância entre a pintura do quadro e a própria ação do olhar do observador". (tradução nossa) Por outro lado, a fotografia carrega o sinal da temporalidade, do signo indicial, que, segundo Peirce (2005), é aquele que estabelece uma relação causal com seu referente, diferentemente do signo icônico que estabelece uma relação de semelhança com o referente.

Como podemos verificar, o advento da fotografia não causa apenas uma mudança técnica, isto é, ela (fotografia) não vai apenas substituir a pintura, mas vai levantar questões epistemológicas das mais diversas, a partir do estudo da natureza dessa linguagem tecnológica e imagética.

Recorremos mais uma vez a Santaella (2007, p. 361), para ilustrar uma das características da imagem fotográfica:

A imagem revelada é uma emanação do objeto, seu traço, fragmento, vestígio, uma marca e prova. [...] O pedaço de realidade, fixado para sempre em uma projeção bidimensional, não é o objeto. É apenas a emanação dele. Decorre de todas essas condições a natureza ao mesmo tempo indicial (um fragmento residual do objeto), icônica (similaridade com o objeto fotografado) e simbólica (resultado de um certo sistema de codificação) da fotografia para usarmos a terminologia da semiótica peirciana.

As teorias que surgem no decorrer do século $X X$ são resultantes desse processo semiótico de representação.

\section{A crise da Pintura - Vincent van Gogh}

Como já mencionamos, a crise da pintura começa com o advento da fotografia, no final do século XIX, quando a pintura já estava afastada dos confinamentos de ambientes internos e desfrutava o ambiente natural. Ao ar livre, os artistas sentiram-se inspirados por um conjunto de elementos 
naturais até então não experienciados. A partir do Impressionismo e do pós-Impressionismo, as mudanças na pintura foram direcionadas para a abstração da forma, e pelo fato de a fotografia estar fazendo a função que era da pintura, ou seja, a representação do "real", os artistas sentiram-se livres para pintar aquilo que eles viam e interpretavam mediante seu estado emocional. Essa maneira de pintar veio a ser chamada de "expressionismo", palavra que foi empregada, pela primeira vez, em 1850, pelo jornal inglês Tait's Edinburgh Magazine, ao evocar, em artigo anônimo, uma "escola expressionista” de pintura moderna. Em 1880, Charles Rowley se pronunciou sobre essa escola, em Manchester, numa conferência sobre a pintura da época, identificando uma corrente "expressionista" de artistas que procuravam exprimir suas paixões. Em 1878, no romance The bohemian, de Charles de Kay, um grupo de artistas também se autodenominava como "expressionista”. Com a verificação de que o verdadeiro expressionismo se disseminava na Alemanha, na Áustria, na Hungria e na Tchecoslováquia, o termo tornou-se uma referência para a arte cujas formas não nasciam diretamente da realidade observada, mas de reações subjetivas à realidade. Atualmente, é considerada "expressionista” qualquer arte onde as convenções do realismo sejam destruídas pela emoção do artista. De fato, a deliberada alteração das formas, o sacrifício do discurso ao essencial, a captação de um mundo em frangalhos, a preocupação com a doença e a morte, a sublimação da loucura em contrastes e dissonâncias, o gosto pelo insólito e a visão de um absurdo que tira para sempre a alegria de viver são comuns a toda manifestação artística moderna que atingiu os limites da expressão.

Foi nesse período que Vincent van Gogh, um dos precursores do Expressionismo, que surge de um desdobramento do Impressionismo e do pós-Impressionismo, teve um papel fundamental na construção da arte moderna. Sua pintura revela a característica de uma arte à busca das impressões individuais do artista, a partir de suas escolhas, de um recorte preferido da natureza, das sensações visuais imediatas, das pinceladas livres, passando um ar de liberdade e qualidade de sensações. Suas últimas pinturas caracteristicamente pertencem a esse período pela sua peculiar forma 
de representação por meio de uma visão que não está mais preocupada em representar a realidade, mas o que o artista vê além dos seus olhos, através de suas emoções despertadas pela natureza que ele observa.

Parece que Van Gogh teria sido um dos artistas que mais questionou a maneira de representar aquilo que ele queria pintar. Uma de suas últimas pinturas, Campos de trigo com corvos (1890), é uma obra que, além de coincidir com o auge das novas descobertas da fotografia, provavelmente foi nesse período que surgiram as primeiras discussões sobre o lugar da arte.

Retomando brevemente as considerações semióticas discutidas anteriormente à luz da filosofia peirciana, é importante rever o conceito de contemplação de Peirce:

Quando contemplamos uma pintura, há um momento em que perdemos a consciência de que ela não é a coisa, a distinção entre o real e a cópia desaparece, e ela é para nós, por um momento, um puro sonho - não uma existência particular, nem geral. Nesse momento, nós estamos contemplando um ícone. (CP 3.362)

Complementando a citação de Peirce, Santaella (2002, p. 86) fala sobre a importância das três categorias de Peirce numa análise semiótica, iniciando pela contemplação:

Antes de dar início a uma análise propriamente dita, devemos nos deixar afetar pela experiência fenomenológica. Abrir os olhos do espírito e olhar para a pintura como uma lenda chinesa em que o observador demorou-se tanto e tão profundamente na contemplação da paisagem de um quadro, que, de repente, penetrou dentro dele e se perdeu nos seus interiores.

No trecho acima, Santaella apresenta a categoria da primeiridade, ou seja, a disponibilidade contemplativa presente na contemplação, "sob o domínio do puro sensível". [No momento em que o observador pode] "impregnarse das cores, das linhas, superfícies, formas, luzes, complementaridades e 
contrastes". (SANTAELLA, 2002, p. 85) De tal modo que, nesse tipo de análise, frente a uma pintura, ainda nos diz essa autora, "o que importa, no entanto, discernir é o modo como esta pintura particularmente representa o que professa representar e, em função disso, quais efeitos está habilitada a produzir em possiveis intérpretes". (SANTAELLA, 2002, p. 88)

Como o primeiro fundamento do signo, as qualidades exibidas devem ser contempladas antes de se passar para os outros dois estágios, ou seja, os sin-signos e os legi-signos. Essa primeira parte é a parte icônica, o que não aponta para nada, apenas à sensação de contemplação, um exercício dos quali-signos. Na segunda categoria, Santaella (2002, p. 86) ressalta que "a experiência de estar aqui e agora diante de algo que se apresenta na sua singularidade, um existente com todos os seus traços que lhes são particulares" é da ordem da secundidade, do real, do objeto que se apresenta a nós. É na terceira, que corresponde à categoria da terceiridade, uma das classificações do signo (o símbolo) onde está presente o conhecimento. "Neste nível, não se trata mais apenas de qualidades apreendidas, nem de singularidades percebidas, mas do enquadramento do particular em classes gerais". (SANTAELLA, 2002, p. 88)

Comumente, as pessoas se precipitam em apontar de imediato para as formas dos objetos, como uma mesa, um homem, uma casa etc. Mas, na sequência dos quali-signos, o segundo "fundamento do signo está no seu caráter de existente, o sin-signo. Tem-se aqui a realidade do quadro como um quadro". Importantíssimo, nesse momento, recomenda Santaella (2002, p. 89), "é nos darmos conta de que não estamos, de fato, diante de um quadro, mas de uma reprodução de um quadro", sobretudo quando estamos diante de qualquer tipo de reprodução, pois o quadro é uma coisa e, sua reprodução, outra. "Este aspecto é muito importante para quem estuda arte” (SANTAELLA, 2002, p. 90), pois, ao se analisar uma cópia de um quadro, os quali-signos são diferentes, por exemplo:

Para a pintura, como objeto único que é, o quali-signo é substancial. Por isso, a exigência de se trabalhar com o original não é meramente formal. Em uma reprodução, as cores adquirem uma pigmentação 
distinta da original. Quando passamos de um quadro a óleo para uma reprodução em papel, perde-se a textura, a marca do gesto. Perde-se, além do mais, a dimensão. $\bigcirc$ tamanho de um quadro é um ato de escolha do artista. As reproduções também perdem esse quali-signo. As qualidades que se transformam devem ser levadas em conta porque quali-signos distintos produzirão efeitos, impressões de qualidade também distintas. Isso posto, se estivéssemos diante do próprio quadro, o sin-signo seria sua realidade particular de um quadro singular, como uma dimensão [...] devendo-se levar em consideração também o lugar que ocupa, seu ambiente de inserção, enfim, seu contexto existencial: as paredes de um museu, de uma habitação etc. [...] $\bigcirc$ terceiro fundamento do signo está nos seus aspectos de lei. Neste caso, esse sin-signo particular pertence à classe de pinturas a óleo. Enquadra-se ainda na classe de pinturas modernas e, no interior dessa classe, no gênero fauvista. Além disso, enquadra-se na tradição das naturezas mortas e em um certo padrão de pinturas em telas retangulares, verticais. (SANTAELLA, 2002, p. 89)

Retomando a pintura de Vincent van Gogh, estar no sul da França, em Arles, foi uma escolha desse pintor, que se deslocou de Paris em busca da qualidade da luz própria do Mediterrâneo, e além dos campos que tanto o inspiraram, esse era um lugar sem igual para exercitar o estudo das cores. Os campos através da cor para Van Gogh eram os elementos fundamentais da pintura; uma pintura realizada ao ar livre, banhada de luminosidade, de cores intensas e puras que para ele tinham a função de representar emoções. Mas, além do que percebemos, como as texturas, tons, manchas, formas não mais delineadas etc., a natureza inspirava os artistas com os seus fenômenos e elementos naturais. Esses são invisíveis na obra, pois existem apenas na comunhão entre artista e seu entorno durante seu processo criativo.

Nas inúmeras cartas escritas por Van Gogh, podemos conhecer sua maneira de ver a natureza, as cores, as casas e a luz que o atraíram para Arles, além de um pouco da sensação de pintar ao ar livre. Em Salles 
(2006a, p. 143), destacamos um trecho, no qual Van Gogh expressa a ação do vento na sua pintura:

Tive dificuldade com o pôr-do-sol com figuras e uma ponte. [...] O mau tempo impedindo-me de trabalhar no local. O imprevisto do tempo provocava um estudo inadequado. [...] Imediatamente recomecei o mesmo tema em uma outra tela. Mas o tempo estava totalmente diferente, numa gama cinza, e sem figuras. [...] Ah, que quadro eu faria se não fosse esse maldito vento. É isto que é enlouquecedor aqui, em qualquer lugar que fincamos o cavalete. $E$ é exatamente por isto que os estudos à tinta não são tão bem acabados quanto os desenhos; a tela treme, este mistral desgraçado é bem incômodo para dar pinceladas que se perturbam com sentimento, como uma música tocada com emoção [...] porque os outros me sujaram em nitidez de toque. Isto é mais erro do vento.

Em Campos de trigo com corvos, há sempre um sentimento em compartilhar e imaginar como um campo tornou-se uma pintura, mas esse espaço não existe em tempo real. Pois, de acordo com Santaella (2007, p. 356), "o olhar que dirigimos a uma paisagem é distinto daquele que dirigimos à pintura de uma paisagem". Mas, antes das interpretações próprias de cada interpretante, apenas nos contentamos em pensar como seriam suas caminhadas por esses campos, já que eles não nos aparecem como no mundo real, eles são interpretações de uma mente humana, a mente de Van Gogh.

Não obstante o amarelo ser a sua cor preferida, Van Gogh, nessa, que foi sua última pintura, mancha, borra a pureza desse determinado tom de amarelo vibrante da sua paleta - que se tornou um ícone - , substituindo-o por um amarelo aterrorizante. Através dessa mudança de tons, tanto no amarelo como no azul do céu, existe uma indicação de que algo paira no ar, visto que, sua cor solar que transmitia vibração e alegria estava contaminada por tons sombrios. Os três caminhos que sugerem direções diversas nessa pintura também são índices, dos quais tiramos conclusões diversas, todas, 
porém, relacionadas a meras possibilidades, pois não sabemos para onde eles nos levarão. E os corvos? $O$ que temos a considerar sobre essa ave carregada de significados e associada à anunciação da morte e ao mau agouro? Poder demiúrgico, mensageiro e guia divino e celeste do sol e da luz, é o corvo que guia as almas na sua última jornada; possuidor dos conhecimentos dos segredos das trevas. $\mathrm{Na}$ mitologia grega, os corvos apareceram primeiramente brancos e eram os mensageiros de Apolo, que os chamuscou de preto no dia em que eles deixaram de trazer boas mensagens, como esperado. Assim como diz a lenda, os corvos presentes na pintura de Van Gogh poderiam, então, ter sido uma antecipação do artista em declarar que a morte estava à sua espera? Todas essas suposições nos levam apenas a constatar que a presença de um bando de corvos num trigal fora pintado por um desejo de expressar através de cores, pinceladas, texturas, luz, algo que residia no âmago de Van Gogh, e por mais interpretações que possamos fazer, a pintura é sempre um enigma.

A série Campos de girassóis, composta por onze pinturas, fora pintada em especial homenagem a Paul Gauguin, e demonstra um dos raros períodos de euforia, alegria e felicidade de Van Gogh. A cor amarela era o símbolo de felicidade, e na literatura holandesa, significava devoção e fidelidade. Já na cultura ocidental, passou a ser relacionada ao ciclo de vida e morte. Ao sair de sua terra natal, Van Gogh leva consigo essa cor, que passa a predominar em sua arte. Quanto ao símbolo de felicidade, não podemos negar a existência de momentos de alegria desfrutados por Van Gogh, mas sua devoção e fidelidade foram sem precedentes na história da arte. Contudo, apesar das informações fornecidas pelo pintor nas correspondências trocadas com seu irmão Theo, devemos estar atentos para os diferentes tipos de interpretantes gerados a partir de uma obra, pois de acordo com Santaella (2002, p. 39-41):

O processo de semiose é desencadeado signo a signo presentes no campo de significação das pinturas, porém ela não instaura uma construção lingüística original para definir suas qualidades, mas constrói o seu repertório de formas, cores, texturas presentes 
nos materiais e outras qualidades perceptíveis, mas em termos da semiótica peirceana, é necessário que haja uma relação simbólica com traços indiciais, que dialoga com a classe dos interpretantes.

Para Deleuze e Guattari (1992, p. 228), “os girassóis de Van Gogh são devires. [...] $\bigcirc$ devir sensível é o ato pelo qual algo ou alguém não pára de devir-outro (continuando a ser o que é), girassol”. Já Georges Bataille (1986) entendia que Van Gogh havia criado o mito de um novo sol, um sol que se espalhava por suas telas e que se reapresenta como gira-sol, associando o pintor a Prometeu, um dos mitos gregos mais presentes na cultura ocidental, conhecido por ter roubado o fogo do sol divino de Zeus para dá-lo aos homens.

O próprio Van Gogh faz referência à sua paixão por essa flor, ao dizer que existia dentro dele um pouco de girassol. Mas, independente das considerações que passam a fazer parte da obra depois que ela se afasta do seu criador, temos apenas que contemplar uma das obras mais famosas do mundo, com o olhar sempre renovado. E mesmo sabendo da crise pela qual a pintura passou durante esse período, é enriquecedor sempre retomar esse e outros períodos com a liberdade que a arte contemporânea nos propicia.

\title{
A Fotografia e seu processo de elevação à categoria Arte
}

\author{
O uso direto da câmara para a revelação, interpretação e \\ descoberta do mundo do homem e da natureza. (tradução \\ nossa) \\ Beaumont Newhall, 1982
}

Através das teorias de alguns autores, como Lucia Santaella, Philippe Dubois, Roland Barthes e Winfried Nöth dentre outros, fizemos um recorte sucinto sobre um dos momentos mais expressivos da história da fotografia.

Iniciemos esta parte, à luz da semiótica peirciana, com Santaella e Nöth, (1997), que dividiram o mundo da produção da imagem a partir do advento 
da fotografia em três grandes paradigmas: o pré-fotográfico, o fotográfico e o pós-fotográfico. Em cada um desses períodos, esses autores fazem uma análise semiótica, que permeia todos os tipos de imagens artesanais, como desenho e pintura, passando pela fotografia que pressupõe a presença de uma máquina e um objeto, que preexistem à sua imagem, incluindo o registro da imagem fixa em suporte específico até o amplo universo da tecnologia digital, com as imagens sintéticas, resultado da transformação de uma matriz numérica em pixels numa tela. Considerando as dimensões postuladas pelas abordagens desses autores nesse período, as primeiras teorias emanam de discussões polêmicas com premissas que abrem perspectivas promissoras, seja por parte da sua constituição tecnológica, seja pelos conceitos e teorias que delas advêm. Nessas primeiras investigações, estava presente o desafio de tornar a imagem fixa num determinado suporte. $\mathrm{Na}$ sequência, o interesse pelo desenvolvimento de equipamentos, lentes, isto é, desde a câmara ao processo de revelação e fixação, passando por inúmeras experimentações sobre a captação da imagem, medida da luz etc., até o interesse em associar à técnica uma visão poética.

Para Santaella (2007, p. 399):

As fotos tradicionais, ao serem reveladas, subordinam-se a um suporte matérico, papel, dispositivos ou coisa parecida. Embora passível de ser reproduzida em um número indefinido de cópias, cada superfície imóvel muda e ocupa um lugar que lhe é próprio em um álbum, moldura, jornal, revista, outdoor, um lugar que pode até mesmo durar no tempo. Essa estabilidade convida e permite a contemplação, a atenção demorada.

Retomando a citação sobre as primeiras ideias que suscitavam a divisão da fotografia em duas partes, passamos à noção da parte física da imagem em si, desenvolvida por Dubois (1994, p. 15-16):

Com a fotografia, não nos é mais possível pensar a imagem fora do ato que a faz ser. A foto não é apenas uma imagem (o produto de uma técnica e de uma ação, o resultado de um fazer e de um saber- 
fazer, uma representação de papel que se olha simplesmente em sua clausura de objeto finito). [...] É em primeiro lugar, um verdadeiro ato icônico, uma imagem, se quisermos, mas um trabalho, algo que não se pode conceber fora do jogo que a anima sem comprová-la literalmente: algo que é, portanto, ao mesmo tempo e constantemente uma imagem-ato, estando compreendido que esse ato não se limita trivialmente apenas ao gesto da produção propriamente dita da imagem (o gesto da "tomada"), mas inclui também o ato de sua recepção e de sua contemplação. A Fotografia, nesse sentido é inseparável de toda a sua enunciação, como experiência da imagem, como objeto totalmente pragmático.

De forma semelhante a Santaella e Nöth, Dubois (1994, p. 53) divide a história da fotografia também em três períodos, a saber: 1 . A fotografia como espelho do real (o discurso da mimese); 2. A fotografia como transformação do real (o discurso do código da desconstrução); 3. A fotografia como traço de um real (o discurso do índice e da referência).

Vamos nos deter um pouco mais na apresentação da passagem da fotografia à categoria arte, considerando relevante pontuar as três perguntas fundamentais formuladas por Dubois: "1. O que está representando? 2. Como aconteceu? 3. Como é percebida?" (DUBOIS, 1994, p. 16) - questões que analisaremos neste texto à luz da obra de três grandes mestres da história da fotografia, com as informações que nos foram disponibilizadas pelo Center For Creative Photography. ${ }^{1}$

Localizado no campus da Universidade de Arizona, na cidade de Tucson, - Center for Creative Photography foi criado em 1975 com a colaboração de Ansel Adams. Primeiramente, contava apenas com cinco arquivos de fotógrafos, incluindo o próprio Ansel Adams, Wynn Bullock, Harry Callahan, Aaron Siskind e Frederick Sommer (fotógrafos americanos), tendo rapidamente se ampliado para agrupar uma coleção que representa a história da fotografia internacional. Hoje, esse espaço possui a maior

1 Disponível em: 〈www.creativephotography.org/.>. Acesso em: 2007. 
coleção de fotografias de qualquer museu do país, com aproximadamente 80.000 obras de 2.000 fotógrafos. Deste Centro, qualquer um dos seus fotógrafos poderia ser escolhido, todavia, por uma questão mais didática (justificada a partir da relação desses fotógrafos com a história da fotografia), optamos por Alfred Stieglitz, Edward Weston e Ansel Adams.

Durante o período formalista, a fotografia foi pesquisada como outra técnica artística qualquer, e seu discurso visava encontrar a marca de originalidade - uma garantia - o certificado de origem, a aura, não sendo possível se pensar em questões que desestabilizassem essa ordem.

\section{Alfred Stieglitz}

De nacionalidade americana, considerado um dos mais importantes fotógrafos na história da fotografia do século XX. Alfred Stieglitz foi morar com sua família na Alemanha, onde iniciou seus estudos em engenharia mecânica na Technische Hochschule, em Berlim. Foi durante essa época (1881) que passou a se interessar pela fotografia, e viajou pelo interior da Europa, fotografando paisagens e camponeses de diversos países. Em The eloquent eye (STIEGLITZ, 2001), podemos ver o homem de espírito jovem, que presenciou, vivenciou e participou dos maiores momentos de desenvolvimento e transformação da paisagem, da sociedade e da cultura americanas, sobretudo de sua cidade, Nova lorque, considerado o mais importante fotógrafo do século XX.

Juntamente com Joseph Keiley, Stieglitz deu início à investigação de novos métodos de exposição e procedimentos de revelação através do silver prints ou gelatin silver prints (camada adesiva de gelatina transparente que fixa os sais de prata no papel), e foi um pioneiro ao defender uma visão da fotografia não como mimetismo, mas como a expressão espiritual do próprio artista, que ficou conhecida como fotografia genuína ou fotografia pura.

Logo nos primeiros anos desse século, em Nova lorque, Stieglitz, já premiado com fotografias que faziam parte do movimento europeu conhecido como Pictorialismo, formou um grupo que investigava as possibilidades de 
fotografar sem o auxílio da técnica de retoque, tanto no negativo como no positivo, com o objetivo de provar que a visão era mais importante do que qualquer tipo de condição e equipamento. Sua obra abrange a série Equivalents [Nuvens] (1930), uma noção simbolista que ele incorporou como filosofia de vida; inúmeros retratos de Georgia O'Keeffe, sobretudo a série Hands [Mãos] e os grandiosos arranha-céus de Nova lorque, fotografados da janela de seu apartamento. Contudo, sua atuação como fotógrafo não se limitou apenas à produção de imagens. Paralelamente à investigação do meio técnico, Stieglitz dedica igual interesse à criação de grupos e revistas especializadas e publicações, como American Amateur Photographers, Camera Club of New York, New York Camera Notes, entre outras, das quais foi editor. A paixão pelas artes era expressa pela relação de amizade que Stieglitz mantinha com vários artistas, a maioria representada por ele em suas galerias em Nova lorque, a exemplo da An american place, que incluía a pintora Georgia O'Keefe, por quem não mediu esforços para torná-la uma das mais bem-sucedidas pintoras do século XX (desconsideramos mencionar o termo artista-mulher, ao que ela deliberadamente sempre se opôs). Além de ter atuado como mentor de artistas emergentes, como Arthur Dove, Marsden Hartley, Ansel Adams, Eliot Porter dentre outros, esse fotógrafo introduziu a vanguarda europeia, representada por nomes como Henri Matisse, Paul Cézanne, Auguste Rodin e Pablo Picasso, no cenário artístico de Nova lorque. Quando participou da "Armory Show", exposição denominada "International Exhibition of Modern Art", em fevereiro de 1913, considerada um marco da arte moderna nos Estados Unidos; o êxito alcançado nesse cenário, que reuniu artistas europeus e americanos, foi além de um notável fotógrafo. Como resultado dessa exposição, sua galeria, um espaço permanentemente experimental, tornou-se mais visível, graças a obras de vários artistas por ele representados, que propiciavam reflexões e debates constantes, e fez com que ele também se tornasse um dos principais divulgadores da arte moderna em Nova lorque, durante a primeira metade do século XX. Por fim, através de esforços impetuosos, Alfred Stieglitz colaborou para estabelecer a fotografia como uma das mais belas das artes. 


\section{Edward Weston}

A fotografia isola e perpetua um momento de tempo: um momento importante e revelador, ou um sem importância e sem sentido, dependendo sobre o entendimento do fotógrafo do seu assunto e mestria do seu processo. (tradução nossa) Edward Weston apud Warren, 2001

Edward Weston foi um dos pioneiros no retratar a essência total de beleza na forma natural. Diferentemente do estilo pictorialista, esse fotógrafo optou por fotografar formas naturais, como verduras, conchas e o corpo humano, destacando-os detalhadamente. Weston dedicava-se intensamente à precisão técnica, o que fez com que ele se tornasse conhecido como o fotógrafo que criou um novo ideal de forma baseada no real absoluto. Essa preocupação de Weston é descrita por Dubois (1994, p. 25):

Toda reflexão sobre um meio qualquer de expressão deve se colocar a questão fundamental da relação específica existente entre o referente externo e a mensagem produzida por esse meio. Trata-se da questão dos modos de representação do real, ou, se quiser, da questão do realismo.

Edward Weston foi além de um tema convencional da sua época, e suas imagens refletiam enigmas de cunho sensual. Foi através de uma delas, denominada Neil, que surgiram as mais polêmicas discussões acerca de conceitos de originalidade, nas últimas décadas do século passado, assunto que abordaremos mais detalhadamente em outro capítulo.

\section{Ansel Adams}

Ansel Adams comungava com Alfred Stieglitz e Edward Weston os principais conceitos por eles criados sobre a definição da fotografia como pura forma de arte, ao invés de uma técnica derivada de outras artes. Com influência da experiência mística do mundo natural, os anos 1930 e 1940 foram definitivos 
para marcar sua obra, onde predominaram as paisagens, motivado pela sua primeira visita ao oeste americano. Foi durante esse período que Paul Strand o convenceu de que a fotografia não era um mero meio técnico, mas uma forma de expressão artística. A partir de então, transmitiu para suas fotografias um novo olhar à natureza como fonte de inspiração poética.

Acolhido e assessorado por Alfred Stieglitz na cidade de Nova lorque, nos meados da década de 1930, Adams expôs suas fotografias na galeria de Stieglitz. Relevante mencionar também a contribuição de Adams na criação do Departamento de Fotografia no New York Museum of Modern Art, em 1940, junto ao historiador da fotografia Beaumont Newhall.

Em 1934, Adams foi eleito para a diretoria do Sierra Club e tornou-se conhecido como um dos maiores defensores da natureza e da sua preservação, mais especificamente da Sierra Nevada e do Yosemite National Park. A sua mais famosa fotografia - Monolith, the face of half dome (1927) - foi resultado de sua primeira grande viagem a esse parque nacional. Juntamente com outros colegas, optou por câmeras fotográficas de grande formato, pois elas permitem um controle extremamente amplo das possibilidades técnicas na captação da imagem, sobretudo em fotografias de paisagens.

Como membro fundador do Grupo $\mathrm{f} / 64$, investiga os detalhes técnicos, formais e criativos com a mesma intensidade, cujos resultados foram incluídos na sua série de três livros, cuja primeira edição data de 1950: $A$ câmera, O negativo, A cópia. Esse grupo tinha como um dos principais objetivos dar ênfase à fotografia pura, imagens nítidas, máxima profundidade de campo, papéis fotográficos com baixo brilho, concentrando-se unicamente nas qualidades do processo fotográfico.

Ansel Adams valorizava os aspectos técnicos da fotografia. Conhecer bem a técnica era o que lhe permitia libertar a sensibilidade, interesse que o estimulou a pesquisar nessa área, incluindo o famoso zone system (sistema de zonas), um método de medição de luz que integra as etapas de exposição, revelação e ampliação do filme. Esse sistema divide a luz em 10 gradações, do branco ao preto, e permite ao fotógrafo visualizar os diferentes níveis de cinza com grande precisão. 
Declarou-se admirador da filosofia da natureza do século XIX e comungava com as ideias de Ralph Waldo Emerson e Henry David Thoreau, voltadas para a espiritualidade e a verdade, filosofia que esse fotógrafo sempre buscou expressar nas suas fotografias, esperando que o observador encontrasse, assim como ele, as fontes inesgotáveis de beleza no mundo natural.

\section{Período Modernista}

Para muitos teóricos, o início da arte moderna começa em diferentes períodos da história da arte: enquanto alguns apontam para o pós-Impressionismo, com Paul Cézanne, outros observam que a pintura de Joseph Mallord William Turner e a diluição dos contornos nas formas impressionistas já davam indícios de uma abstração da imagem. Por sua vez, "André Malraux observou que a Arte Moderna nasceu, sem dúvida alguma, no dia em que as idéias de arte e de beleza foram separadas" (MALRAUX, 1945 apud STILES e SELZ, 1996, p. 11), sugerindo que Francisco de Goya poderia ter sido a partida para essa mudança. (tradução nossa) Não obstante muitas sejam as hipóteses sobre quando, quem e quando, as transformações que surgem nesse período trazem consigo duas funções importantes: uma que é de representação, e a outra, de significação.

A partir do Impressionismo, que evoluiu em direção à abstração da forma, o período moderno veio a se consolidar com a arte abstrata, tendo Wassily Kandinsky como o grande mentor. Mas para iniciarmos esta parte, retomamos a citação de Regis Debray (2003, p. 83-84), já mencionada anteriormente, na qual ele considera a paisagem como a última da fila na escala social dos gêneros, ao tempo em que questiona se a primeira abstração de Kandinsky, uma aquarela de 1910, não teria sido uma paisagem. Esta possibilidade postulada por Debray (2003) nos levou a verificar a obra desse pintor, nesse primeiro período, e encontramos formas abstratas de origem orgânica exploradas por Kandinsky, diferentemente de seus colegas Piet Mondrian e Kasimir Malevich. 
As primeiras abstrações de Kandinsky foram inspiradas em paisagens, sobretudo entre 1906 a 1908, em Murnau, um povoado pequeno da Bavária, onde ele viveu. A pintura $A$ montanha azul (1908-1909) já apresenta sua tendência à abstração como índice da separação entre a cor e a forma: uma montanha azul, duas árvores amplas, uma amarela, e outra, vermelha. Murnau [Jardim] (1910) e Grüngasse em Murnau (1909) são representações abstratas inspiradas nas paisagens que ele tanto admirava e observava durante os verões que passava nessa cidade. Também influenciado pela ópera de Richard Wagner Lohengrin, Kandinsky é considerado um dos principais teóricos sobre a arte abstrata pela sua dedicação à reflexão sobre o processo de construção e desenvolvimento da arte desse período.

Seu primeiro livro, Do espiritual na arte, concluído em 1910, ano em que pinta sua primeira aquarela abstrata, segundo Sers (apud KANDINSKY, 1996, p. 11), "do Natal de 1911 ao outono de 1912, em um ano, Do espiritual na arte teve três edições sucessivas”. Certamente, trata-se de um dos clássicos mais procurados. Na sequência, Kandinsky publica Ponto e linha sobre o plano, em 1926, que, de acordo com o pintor, é uma continuação orgânica de Do espiritual na arte, que, junto à sua obra, serviram tanto como defesa e promoção da arte abstrata, como uma prova de que todas as formas de arte eram igualmente capazes de alcançar o nível da espiritualidade. Através de suas pesquisas, pode-se observar o comportamento desse artista frente ao seu tempo, em plena sintonia com o início do século $X X$. Sua preocupação pela ciência e pela estética o levaria ao convívio da Escola da Bauhaus, mantendo uma ligação estreita entre a teoria e a prática, uma das características essenciais de toda a sua obra.

Ao se referir à forma como expressão exterior do conteúdo interior, Kandinsky (1996, p. 28) atribui a Paul Cézanne a criação de uma nova lei da forma, ao dizer: "não é nem um homem, nem uma maçã, nem uma árvore que Cézanne quer representar, ele serve-se de tudo isso para criar uma coisa pintada que se chama imagem". Em sua pesquisa, Kandinsky (1996, p. 83) considera a arte ligada a um determinado tempo, ao dizer que:

1. Cada artista, como criador, deve exprimir o que é próprio de sua pessoa - elemento da personalidade. 
2. Cada artista, como filho da sua época, deve exprimir o que é próprio da sua época.

3. Cada artista, como servidor da arte, deve exprimir o que, em geral, é próprio da arte.

As considerações apresentadas acima são reflexões que demonstram a intimidade e a cumplicidade que os artistas desenvolvem com a sua pintura. Quanto em relação às cores, vejamos uma das mais expressivas passagens descritas por Kandinsky (apud DUVE, 1998, p. 158) sobre sua primeira experiência com as tintas e as cores, na qual ele relata que, como um garoto de 13 ou 14 anos, aos poucos, economizou dinheiro suficiente para comprar uma caixa de tintas a óleo. A sensação de ver pela primeira vez tintas emergindo do tubo, apenas pela pressão de seus dedos: "Vieram esses estranhos seres, um após outro, o que chamam de cores - exultantes solenes" [...]. Segundo Kandinsky, esta experiência o acompanhou por toda a sua vida, e, ao lembrar-se desse momento, ele ainda se recordava da sensação que sentiu naquele instante.

Santaella (1989, p. 59) descreve as principais características da arte abstrata, do ponto de vista semiótico:

As formas não-representativas, no limite, dizem respeito à redução da declaração visual a elementos puros: tons, cores, manchas, brilhos, contornos, formas, movimentos, ritmos, concentrações de energia, texturas, massas, proporções, dimensão, volume etc. A combinação de tais elementos não guarda conexão alguma com qualquer informação extraída da experiência visual externa.

Diferentemente de Kandinsky, Piet Mondrian investigou a abstração geométrica, demonstrando seu interesse pelos conceitos e leis da forma. Vejamos:

A vida do homem moderno cultural está gradualmente desviando-se do natural: a vida vem se tornando cada vez mais abstrata. Como 
o natural (externo) torna-se cada vez mais 'automático', vemos o interesse da vida fixado cada vez mais no interno. A vida do homem verdadeiramente moderno nem está dirigida diretamente em direção ao material por prazer nem em direção ao predominantemente emotivo: mas toma uma forma de vida autônoma do espírito humano tornando-se consciente. $\bigcirc$ homem moderno - embora uma unidade de corpo, alma, e mente - manifesta uma consciência mudada: todas expressões de vida supõem uma aparência diferente, uma aparência determinantemente mais abstrata. Antes de tudo há a lei fundamental de equilíbrio dinâmico que é oposto ao equilíbrio estático necessitado pela forma particular. A tarefa mais importante de toda arte, então, é destruir o equilíbrio estático estabelecendo um equilíbrio dinâmico. A arte não-figurativa exige uma tentativa do que é uma conseqüência desta tarefa, a destruição de uma forma particular, e a construção de um ritmo de relações mútuas, de formas mútuas de linhas livres. Devemos suportar mentalmente, no entanto, uma distinção entre estas duas formas de equilíbrio para evitar confusão; para quando falamos de equilíbrio puro e simples nós podemos ser para, e ao mesmo tempo contra, um equilíbrio na obra de arte. É da maior importância anotar a qualidade destrutivo-construtiva do equilíbrio dinâmico. (MONDRIAN, 1946, p. 35-36)

\section{Para Santaella e Nöth (1997, p. 147), na pintura de Mondrian e na pintura do Construtivismo e do Suprematismo predominam o protótipo do legi-signo icônico, ou seja:}

[...] as formas são construídas de acordo com as leis geométricas e relacionadas umas às outras através de cores primárias, formando uma composição harmônica. [...] Uma semiótica da pintura nãofigurativa sob uma perspectiva peirciana é possível sem que uma semântica própria dos elementos cromáticos e formais deva ser pressuposta. A tentativa de basear um tal nível em uma semiótica dos signos abstratos ou plásticos, de acordo com a qual formas como o círculo ou o triângulo podem ter significações próprias, 
mas, na maioria das vezes, somente muito vagas e associativas, é extremamente questionável ou, pelo menos, logocêntrica, não somente devido à vagueza das supostas significações, mas, principalmente, tendo em vista a particularidade da pintura abstrata, que é a sua própria negação semântica. As cores e as formas da pintura não-figurativa são, na perspectiva da semiótica peirciana, signos autológicos, que não precisam referir-se a mais nada a não ser a si mesmos, à sua própria materialidade e à sua estrutura.

\section{Alegoria, Colagem e Fotomontagem}

No ensaio The madonna of the future: essays in a pluralistic art world, Danto (2001a) descreve a fotomontagem através da obra de John Heartfield, uma imagem autorreferencial, na qual esse artista apresenta uma foto sua segurando uma grande tesoura colada ao lado de uma fotografia do burocrata Zörgiebel. Danto afirma que não obstante a imagem indicar um homem segurando a cabeça com os seus dedos - à maneira como seguraria um pedaço de papel -, o que realmente ele segura não é uma cabeça real, mas um papel. Como um dos organizadores da "Primeira Exposição Internacional Dada de 1920", John Heartfield não poderia endereçar o manifesto através de uma pintura, já que nessa época as fotografias estavam sendo largamente utilizadas. A tarefa não era mais representar o mundo, mas redistribuí-lo. Então o uso de imagens fotográficas na montagem de Heartfield, cortando a cabeça de Zörgiebel, não era uma proposta para o fim da pintura, mas o que deveria ser indicial era que o artista estava apenas cortando em pedaços uma fotografia e não uma pessoa.

O manifesto da "Exposição Internacional Dada de 1920" apresenta John Heartfield como o "monteurdada", e de fato monteur é o que ele preferiu ser chamado, ao invés de "artista". Os cartazes de divulgação dessa exposição proclamam a morte da arte e derivadamente a morte de artistas; mas fazem saudações à maschinenkunst (à arte da máquina), a qual naturalmente é a reprodução fotográfica, mecânica. Por montieren entende-se "organizar", 
e a arte de fotomontagem é precisamente a arte de organizar fotografias de tal maneira que seja possível extrair as afinidades inesperadas fundadas nas grandes metáforas. Portanto, essa técnica é considerada a principal contribuição artística do movimento Dada de Berlim, e quase que cada um dos membros desse movimento reivindica ter sido o seu inventor, como Raoul Hausmann, que afirma tê-la inventado em colaboração com sua companheira, a grande monteuse Hannah Höch, assim como Heartfield, em colaboração com George Grosz.

Os dadaístas de Berlim eram considerados revolucionários por natureza, eles não viam sua arte como meramente uma parte do movimento comunista, mas da campanha contra o nazismo, isto é, ao utilizar esse meio, cortar, colar, modificar, eles endereçavam uma mensagem pelas extensões secundárias, ou seja, entrar no processo político. Hoje, essas montagens emolduradas e expostas ao longo de paredes de museus parecem não fazer mais nenhum sentido, ou um sentido incongruente, pois elas foram feitas com um determinado fim, seja pelo meio técnico, seja pelo conteúdo. Assim, o que contemplamos é o talento gráfico de Heartfield e seu meio estético. Quanto à interpretação, exige um conhecimento da história da Alemanha para se poder entender essas imagens. Segundo Danto (2001a), não se faz política através da arte exposta em museus. A obra pode chegar a esse espaço mais tarde, apenas como história de um passado, mas o que esses artistas naquela época queriam era fazer com que o povo visse o seu entorno. Por isso, as montagens de Heartfield possuem uma carga visual importante, com o propósito de mover mentes e mudar ou despertar sentimentos por meio de imagens. Nesse aspecto, não se trata do múltiplo, próprio do processo fotográfico, mas de uma arte única, visto que todas as montagens de Heartfield eram originais neste sentido.

\section{Arte no barulho de um motor}

Sob o termo genérico "modernista", surgem as vanguardas, momento que Argan (2002, p. 185) descreve, a saber: 
Por volta de 1910, quando ao entusiasmo pelo progresso industrial sucedeu-se a consciência da transformação em curso nas próprias estruturas da vida e da atividade social, formar-se-ão no interior do Modernismo as vanguardas artísticas preocupadas não mais apenas em modernizar ou atualizar, e sim em revolucionar radicalmente as modalidades e finalidades da arte.

No início da Primeira Guerra Mundial, durante o processo revolucionário pelo qual a Rússia estava passando até chegar à revolução bolchevique, de 1917, o continente europeu vivenciava modificações profundas. Ao mesmo tempo, o conceito de arte moderna se espalhava pelo mundo.

Nos Estados Unidos da América do Norte, a primeira exposição de arte moderna foi denominada "Armory Show" (1913); na Europa, Cubismo, Futurismo e vários outros grupos estavam em plena atividade; no entanto, o manifesto Dada (1918), de Tristan Tzara Tzan, pode ser considerado um marco de grandes mudanças na arte, ao sugerir que esse movimento não representa um estilo, mas uma visão de mundo.

As atitudes dos dadaístas não estavam apenas circunscritas ao objeto arte. Intensamente ativos enquanto cidadãos provocadores, não carregavam em si a imagem romântica do artista preso ao atelier. Deste modo, esses artistas organizaram eventos públicos incendiários, em agitadas sessões mixed-media no bar Cabaret Voltaire, em Zurique, Suíça, que de certa forma antecipam a Performance Art. Conquanto o caráter da crítica à sociedade burguesa era inerente a esse período, os dadaístas levaram essas críticas ao extremo, tornando-se eles os mais agressivos dessa época, ao rejeitar, com veemência, a moral da classe média.

É com essa proposta de negação da estética vigente que surge Marcel Duchamp. Inicialmente pintor, rapidamente vai se afastar da pintura, ao verificar os limites que cercavam sua criatividade, rompendo com a configuração bidimensional. $\mathrm{O}$ surgimento dos seus ready-mades torna-se um dos principais índices de contemporaneidade, que vão marcar todo o século $X X$, dando origem ao que veio a ser denominado, bem mais tarde, nos anos 1970, de apropriação. 
Vejamos mais uma vez algumas considerações feitas por Santaella e Nöth (1997, p. 147), à obra desse artista, considerada por eles como "um gesto radicalmente invisivel":

Esse é o caso do objet trouvé. $O$ objeto, por exemplo, o urinoir de Duchamp, deslocado do contexto, esvazia-se de sentido, não significando nada além de si próprio, e é, assim, um ícone puro. Ao mesmo tempo, ele também é um sin-signo devido ao gesto da escolha do artista. Esta escolha faz do produto de massa industrial uma obra singular, que só se refere, além de a si mesma, ao artista que fez do objeto uma obra de arte através de seu ato de seleção e exposição.

Contudo, apesar de todas essas investigações das primeiras décadas do século XX, a arte ainda estava limitada, em geral, ao plano pictórico e à pintura.

A Bauhaus, nesse contexto, exerce um papel fundamental e nela ainda podemos pontuar vários índices de contemporaneidade. Com o perfil de uma escola de arte e design, e com orientação tecnológica que pretendia dedicar à arte a solução dos problemas concretos e práticos da vida social, essa escola procurou, sobretudo, fazer da educação estética o eixo do sistema educacional de uma sociedade. Argan (2002, p. 394) fala sobre "a genética da forma, realizada na Bauhaus como uma espécie de cartilha desenvolvida pela escola”. Ademais, o trabalho desenvolvido por outros artistas, a exemplo de Paul Klee, nesse espaço acadêmico, reflete esse raciocínio: transforma a prática em teoria e a teoria em método didático, que, ainda segundo Argan (2002, p. 271-272):

Na teoria e na didática da Bauhaus, certamente predomina a tendência de geometrização das formas; todavia não se trata de um cânone como no Purismo francês. Poder-se-ia dizer que a forma geométrica é uma forma pré-padronizada; é-nos tão familiar que podemos utilizá-la independentemente de seu significado conceitual originário, como um signo a que se pode atribuir conforme circunstâncias, 
diferentes significados. É exatamente o que Kandinsky pretende demonstrar nas pinturas posteriores a 1920, as quais parecem estudar, deliberadamente, os infinitos significados que o mesmo signo geométrico pode assumir, conforme se modifique a cor ou a situação espacial. $\bigcirc$ método projetual da Bauhaus, porém, não é um método para encontrar a forma correta, a Gute Form: estimulante para os processos psíquicos da consciência; é a forma que não se apresenta como dada, mas é captada em sua formação, isto é, no dinamismo que a produz.

Nesse ambiente, as cores de Paul Klee e Josef Albers se destacam. Em Homenagem ao quadrado, uma série rigorosa que teve início bem mais tarde, em 1949, Josef Albers deu continuidade à investigação de interações seriais nas percepções psicológicas e fisiológicas provocadas pela cor e pela forma, bem como de interações cromáticas com quadrados coloridos e planos organizados concentricamente.

Apesar de representar um mundo à parte, a Rússia, até o início dos anos 1920, era um polo importante na gestação da arte moderna. Passando internamente por um período revolucionário que culminaria com a revolução bolchevique, a arte soviética moderna se manifestava através do cinema de Sergei Einsenstein, da poesia de Vladimir Maiakovsky, Kasemir Malevitch e o Suprematismo, o Construtivismo russo e a pesquisa gráfica industrial de Alexander Rodchenko; além de também serem russos Wassily Kandinsky e Marc Chagall.

O Suprematismo, cuja figura maior é Kasemir Malevitch, empreende uma pesquisa metódica sobre a estrutura funcional da imagem. A identidade entre ideia e percepção, a fenomenologia do espaço, o símbolo geométrico e a abstração absoluta foram os elementos mais investigados. De acordo com Malevitch, no período suprematista, o quadro não significava um mero objeto, e sim um instrumento mental, uma estrutura, um signo, que define a existência como equação absoluta entre o mundo interior e o mundo exterior. Enquanto fundador dessa corrente, Malevich levou o Abstracionismo geométrico à sua forma mais simples. Na sua obra de 1918, 
Composição suprematista, tentou eliminar todos os elementos considerados por ele supérfluos, incluindo a cor, que antes aparecia sempre em forma de quadrado, a exemplo de Quadrado preto sobre fundo branco.

No manifesto The non-objective world, primeiramente publicado em 1915, esse pintor expõe o que a pintura significa para ele e seus colegas pintores, ao expressar que a arte devia estar livre do lastro da objetividade, ao associar o quadrado suprematista e as formas, sempre prosseguindo para fora, às marcas primitivas (símbolos) do homem aborígine, representou, em sua combinação, um não ornamento, mas um sentimento de ritmo. Como objetivo de seus membros, o Suprematismo não trouxe em si um novo mundo de sentimento, mas, antes, uma nova forma direta de representação do mundo do sentimento, abrindo novas possibilidades à arte.

Esse manifesto demonstra a intenção e a preocupação de Malevich com o papel da arte, ao declarar que o artista não devia pintar telas pequenas de rosas perfumadas, visto que tudo isso era uma representação morta, apontando para a vida. Sua proposta era libertar a pintura do peso de representar coisas, a fim de permitir que ela pudesse fluir no reino de sonhar com o futuro de forma diferente. Uma arte que poderia mudar o pensamento do homem para ver o mundo através de uma perspectiva ética, de crescimento, para alcançar seus bens ideais; e o quadrado preto se ampliaria infinitamente em cada direção, num espaço que abrigaria todos os desejos de um futuro melhor.

No entanto, uma obra somente contém todas essas informações através do discurso verbal do artista, visto que as imagens em si não têm essa competência. Sem essas informações, no campo da semiótica peirciana, teríamos que fazer uma interpretação muito mais vaga, como nos afirmam Santaella e Nöth (1997, p. 147), a seguir:

O protótipo da pintura como quali-signo icônico e a pintura monocromática, que talvez seja aquela que nega a relação referencial da imagem de maneira mais radical. [...] Uma imagem monocromática consistindo somente da cor azul, conforme o ponto de vista, ou não significa absolutamente nada, ou se refere a infinitas coisas, a saber, 
todas as coisas azuis no mundo. Já que ela é referencialmente tanto vazia como totalmente aberta, o observador precisa abrir mão da ilusão da referência, da relação com o objeto, concentrando-se somente na materialidade e, assim, no aspecto da primeiridade da própria imagem. Realmente uma tal forma de recepção encontra-se também na teoria da pintura monocromática. $\bigcirc$ observador deve se aprofundar na materialidade da cor, que se apresenta, através de uma contemplação mais pormenorizada, em várias nuanças.

\section{Construtivismo}

Também no âmbito de um enfoque racional, teremos ainda outro movimento - o Construtivismo -, originalmente derivado da arte russa moderna, que surgiu a partir dos experimentos cubistas de Pablo Picasso e George Braque, como uma maneira intelectualizada de composição plástica, uma produção baseada em ciência e técnica, utilizando formas geométricas e áreas de cores puras. Esse movimento repudiava o conceito de gênio, intuição, inspiração e autoexpressão.

Após uma visita feita a Picasso, no seu atelier em Paris, o escultor russo Vladimir Tatlin iniciou suas investigações e formulou o princípio construtivista (autenticidade do material). Sobre os dois irmãos, Antoine Pevsner e Naum Gabo, apresentamos duas citações de Argan, a seguir:

O objetivo de ambos é demonstrar que entre a ciência e a arte existe não uma relação e sim uma continuidade. O postulado ideológico inicial permanece firme: a arte não pode ser mais uma atividade dedicada a produzir, com técnicas refinadas, uma mercadoria de qualidade, destinada a uma clientela de elite. Naum Gabo assegurava que o uso construtivo das formas elementares, as linhas, as formas e as cores, assim como o uso das ferramentas e técnicas pelo engenheiro, poderiam possuir seus próprios significados expressivos independentes da sua natureza. (ARGAN, 2002, p. 454) 
○ objeto artístico já não tem curso legal. $\bigcirc$ artista é um intelectual que realiza uma pesquisa científica no campo do conhecimento estético: os objetos que fez não têm valor em si, mas enquanto instrumentos e demonstrações de pesquisa. Exclui-se que a ciência opera no âmbito do pensamento abstrato e não implique operações técnicas. Assim como não pode existir uma distinção entre o pensamento e a experimentação, da mesma forma, não existe uma hierarquia entre as disciplinas, sendo todas inspiradas pela vontade de alcançar verdades objetivas, indiscutíveis, não suscetíveis de interpretações unilaterais ou pessoais. As construções plásticas de Pevsner e Gabo não são propriamente esculturas, porque implicam a intenção de anular o próprio conceito de escultura como disciplina tradicionalmente definida por certas finalidades, certos procedimentos, certos materiais. A morfologia plástica de Pevsner e Gabo é geométrica, tendo suas origens na teoria suprematista de Malevitch; é, propriamente falando, uma geometria fenomenizada pela qual as figuras não são símbolos de conceitos, mas formas concretas cuja estrutura e comportamento podem ser entendidos. Assim, desenvolve-se o princípio: a geometria não é a representação de espaço como ele é, e sim como poderia ser, e desse modo já não adere a uma noção, e sim a uma imaginação ou invenção do espaço. (ARGAN, 2002, p. 454-455)

O espaço em que a arte desse período se configura extrapola o âmbito artístico, em busca de uma arte que se associe à sociedade, uma forma política de união entre arte e indústria voltada para o povo. Os materiais e as técnicas tradicionalmente artísticas dão lugar a procedimentos próximos ao design e à arquitetura.

Foster (1988) acredita que a era moderna fora dominada pelo sentido da visão, o qual nos dá a sensação de distanciamento dos seus antecedentes pré-modernos e possivelmente dos seus sucessores pós-modernos. Considerado como sendo um período ocularcêntrico, pela ênfase à visão, à cor e às formas, Santaella e Noth (1997, p. 146-148), ainda nos oferecem esclarecimentos enriquecedores, a seguir: 
Além da pintura monocromática, que, do ponto de vista da teoria da informação, apresenta um máximo de ordem estrutural, as imagens não-figurativas, que correspondem ao princípio oposto, ao caos estrutural total, também pertencem à classe dos quali-signos icônicos. Imagens produzidas aleatoriamente são exemplos desse outro extremo. O receptor é confrontado com formas e constelações cromáticas totalmente imprevisíveis, nunca antes vistas, que, livres de qualquer tipo de esquema composicional e sem nenhuma tradição de gênero (regularidade, terceiridade), só têm efeito por sua própria qualidade. Nada se parece com elas e, exatamente por isso, tudo também pode ser semelhante a essas imagens.

Esses autores consideram que, em uma análise semiótica da pintura do período formalista, o que essas pinturas representam é uma investigação puramente pictórica, cujo material estava condicionado à tinta, ao pigmento, sobre um espaço plano (tela) bidimensional. Nesse período, o que os artistas propunham era justamente essa ideia, a de abstrair a imagem real, resultado das primeiras tentativas que surgiram no Impressionismo, período em que as imagens foram perdendo sua forma, diluindo-se em pinceladas. Entretanto, muitas das pinturas que poderiam ser consideradas "abstratas" são, na realidade, pinturas figurativas abstraídas. Por outro lado, toda pintura representativa, por mais realista que seja, baseia-se num certo grau de seletividade. Mediante a seleção e a distorção deliberadas, o artista faz uma declaração pessoal. Muitos pintores usam a figura, a paisagem ou a natureza morta como ponto de partida para quadros que, uma vez terminados, não conservam nenhum índice de suas origens. Nesse mesmo contexto:

Atualmente podemos ver que, quando os artistas da arte moderna obstinada e progressivamente buscaram a independência da imagem dos objetos do mundo, eles estavam radiografando o futuro. Suas criações já traziam os germes das programações que hoje tornam a infografia possível. [...] os que continuavam a ostentar seus corpos, pintores ou escultores, desenvolviam um vasto trabalho 
teórico que finalmente os transformará nos últimos filósofos autênticos, a visão naturalmente relativista do universo permitindo-lhes preceder os físicos em novas apreensões das formas, da luz e do tempo. (SANTAELLA e NÖTH, 1997, p. 183)

Muito embora a primeira metade do século $X X$ tenha sido um período predominantemente marcado pela arte abstrata, vale ressaltar mais uma vez o papel das vanguardas modernistas e sua contribuição para a construção da contemporaneidade nas artes visuais, sobretudo no que diz respeito à tentativa de ruptura com os materiais, imagens e espaço lógico das artes plásticas.

Se os anos 1920 foram de grande euforia cultural a ponto de eternizá-los como de solidificação do conceito de arte moderna, Paris vivia momentos palpitantes nas artes, e, em grande parte, essa arte era a locomotiva desta euforia até a chegada de Hitler ao poder, como primeiro ministro da Alemanha, fato esse que inibiu as artes, levando inclusive a Bauhaus a fechar suas portas. Talvez por não entender nada desse assunto, ou talvez por entender o caráter eminentemente sarcástico da arte moderna (o sarcasmo ao poder, à figura da autoridade, especialmente nos dadaístas), Hitler chamava a arte moderna de arte degenerada.

Por conseguinte, a partir da década de 1930, a Europa passou a conviver com essa realidade. A expansão e a ocupação territorial dos nazistas fizeram com que vários intelectuais, cientistas e artistas, deixassem esse continente e partissem em busca de ares menos carregados. $\bigcirc$ ambiente de agitação cultural tinha se transformado bastante.

\section{A travessia do Atlântico: Europa e América}

Paris era o centro das artes, considerada o paraíso dos artistas e intelectuais, e assim surgiu a ideia da Escola de Paris. Mas, na realidade, Paris era o mercado artístico predominante naquela época, pois a verdadeira escola, a propriamente dita, era a Bauhaus, cujos objetivos era unir o artista ao social (ao ensino). 
Mas, como nos informa Argan (2002), em uma sociedade burguesa, que sempre é uma sociedade mercantil, o mercado torna-se mais importante do que a escola. Assim, acima de tudo, o mercado parisiense se dirigia a uma sociedade existente, e a Bauhaus a um projeto de sociedade do futuro.

Desse modo, explica-se que a influência da chamada École de Paris (Escola de Pintura de Paris ou Escola de Paris) sobre a formação e a irradiação da arte moderna foi muito maior do que a Bauhaus, onde, no entanto, trabalhavam e ensinavam artistas de primeira grandeza, a exemplo de Wassily Kandinsky, Paul Klee, Joseph Albers, Lyonel Feininger, dentre outros.

Que a arte seja internacional, como igualmente sustentavam os teóricos da Bauhaus, é um fato indiscutível. Na Escola de Pintura de Paris não se procurava uma unidade da linguagem, todos foram aceitos por igual. Seu aspecto mais significativo, o de um grande bazar, não poderia nunca ser rotulado de uma maneira única. Era um refúgio também político. Artistas impacientes com a oficialidade acadêmica dos regimes totalitários buscaram a liberal e hospitaleira Paris. Suas salas de aulas eram os cafés da boemia parisiense.

Pouco antes da Segunda Guerra Mundial, tornou-se visível para os intelectuais europeus a crise das ciências europeias e do sistema cultural fundado na racionalidade, enquanto que, para Argan (2002, p. 507), os Estados Unidos não viam essa relação da mesma maneira:

A cultura americana, pelo contrário, ignora essa proporcionalidade de base: a ciência não é uma atividade em contraste com uma cultura fundamentalmente humanista e não tem limites a seu progresso, da mesma forma como o arquiteto pode erguer um arranha-céu com mais de cem metros de altura, sem violar qualquer medida proporcional, ou o pintor, lançar as tintas ao acaso ou cobrir uma enorme superfície com uma cor uniforme sem ofender a memória de Rafael ou Rembrant. O problema, se tanto, não nascia antes, e sim depois - apenas depois é que se pode perguntar, se se quiser, para o que serve ou o que significa a criação do artista. 
Com a entrada da França e da Inglaterra na Segunda Guerra Mundial, artistas e intelectuais começaram a sair de Paris, que até então teria sido a capital da arte ocidental por mais de um século. Vindos da Alemanha e de outras nações europeias, vários criadores mudaram de continente em busca de uma nova terra livre.

Segundo Fineberg (1996), dos artistas modernistas, pouquíssimos permaneceram em Paris, a exemplo de Pablo Picasso, Henri Matisse e Wassily Kandinsky, fosse pelo fato de alguns já não serem tão jovens, fosse devido a implicações políticas, a exemplo de Picasso, cuja permanência na Paris ocupada pelos nazistas tinha uma conotação confrontatória. E do outro lado do Oceano Atlântico estavam os Estados Unidos da América do Norte, mais precisamente na figura da cidade de Nova lorque, para a qual se dirigiram diversos criadores e personalidades dos movimentos modernistas.

Os surrealistas já tinham conquistado Nova lorque, assim como Marcel Duchamp, que há anos lá vivia, e Albert Einstein, um dos primeiros a imigrar para essa cidade. Talvez neste momento tenha havido uma mudança do centro de produção cultural.

A reação dialética entre a cultura americana e a cultura europeia estreita-se a partir desse novo encontro de continentes. Além de artistas, estudiosos, literatos, intelectuais, enfim, um contingente imigratório cultural invade os Estados Unidos. Esse fluxo aumenta quando a Segunda Guerra Mundial é deflagrada e os nazistas ocupam quase toda a Europa. O encontro dos artistas americanos com os artistas europeus se deu, no campo das artes, a partir do Surrealismo. Contudo, os artistas americanos dos anos 1940 foram mais influenciados pelo Surrealismo abstrato. Daí alguns estudiosos afirmarem que a Europa teve um Surrealismo mais figurativo e a América um Surrealismo mais abstrato. Nota-se, nesse período, uma preocupação em definir uma nova cultura artística em Nova lorque. E a chegada dos europeus à América deu-se num período crítico devido à depressão econômico-financeira dos anos 1930.

Vejamos um pouco da história desse período. Em decorrência da grande depressão de 1930 que assolou a América, os artistas foram beneficiados através de programas experimentais criados pelo então presidente 
Franklin Roosevelt, como o Public Works Art Program e Works Progress Administration (WPA) e o Federal Arts Project (FAP), e o Projeto de Fotografia, criado pelo Farm Security Administration, com o objetivo de documentar o povo da área rural e a pobreza urbana. Esses programas foram criados por solicitação do artista americano George Biddle (então residindo em Paris), através de uma carta endereçada diretamente ao presidente Roosevelt, em 9 de maio de 1933, na qual ele diz:

Os artistas mexicanos têm produzido a melhor escola nacional de pintura em mural desde a Renascença Italiana. Diego Rivera disse que tudo isso só foi possível graças ao projeto criado pelo presidente do México em 1920 - 1924, Álvaro Obregon, que deu trabalho aos artistas com um determinado salário para que eles pudessem se expressar nos muros dos edifícios públicos, prédios do governo, as idéias sociais da revolução mexicana. Os artistas jovens americanos também estão conscientes como nunca da revolução social que nosso país e nossa civilização estão passando, e eles estão ansiosos para expressarem essas idéias numa forma de arte permanente. (BIDDLE, 1933 apud FINEBERG, 1996, p. 26-27, tradução nossa)

Tendo acatado a sugestão de George Biddle, estima-se que esses programas empregaram 6.000 artistas, por 23 dólares semanais, no bairro denominado Greenwich Villlage, na cidade de Nova lorque, e que resultou em mais de duzentas mil obras, aproximadamente, entre mural, pintura, gravura e fotografia. Não obstante o apoio tenha sido pelo período de oito anos (1935-1943), para os artistas que participaram desse projeto foi um tempo considerado suficiente para que eles pudessem atravessar a crise financeira desse país, além de, ao mesmo tempo, terem podido sobreviver fazendo arte, como era o seu desejo.

Nesse período, não apenas os artistas visuais foram responsáveis pela construção de uma arte solidificada internacionalmente, mas escritores, poetas, cientistas, filósofos. Dentre outros intelectuais, William Carlos foi 
um poeta americano que teve uma grande influência do Dadaísmo e do Surrealismo, bem como influenciou artistas de grupos, como Black Moutain School, San Francisco Renaissance, New York School e Beat Generation.

A chegada dos europeus na América resultou no que denominamos de passagem de escolas (Paris - Bauhaus - Nova lorque). Em 1943, já se falava no mundo artístico de Nova lorque sobre o aparecimento de um novo movimento. Como grupo, esses artistas tornaram-se conhecidos como "expressionistas abstratos" ou, como eles próprios preferiam, "A Nova Escola de Nova lorque" (School of New York).

Certamente, as correntes mais atuantes na virada para a segunda metade do século XX estavam fazendo pintura, do Expressionismo abstrato quase performático da Escola de Nova lorque às outras variações do Expressionismo europeu e suas manifestações locais: Alemanha, Grupo CoBrA, dentre outras.

Se o Expressionismo abstrato foi o primeiro movimento estético que reuniu as raízes europeias e americanas, como um reflexo da influência de artistas europeus fugidos de uma Europa dominada por Hitler, Max Ernst, Fernand Léger, entre outros, sintetizaram as diversas fontes da história da pintura moderna desde o expressionismo de Vincent van Gogh às abstrações de Kandinsky, dos campos de cor saturados de Matisse às formas orgânicas e à fascinação do surrealista Joan Miró pelo inconsciente.

Com um forte teor introspectivo de elementos espirituais, expresso em telas de grandes proporções, esses artistas buscavam sua própria identidade através de um "novo" processo de trabalho com suas técnicas específicas. $\bigcirc$ espaço nesse movimento tornou-se real, pois eles não viam a tela como um espaço bidimensional, decorativo, limitado e sim como uma extensão do seu próprio espaço. Ao abandonarem o cavalete, a pintura passou a ser vista como um evento, principalmente na obra de Jackson Pollock. Historiadores estabelecem uma íntima ligação entre o Surrealismo e os primeiros trabalhos de Pollock, e das "quase" releituras que William de Kooning fazia de quadros de Picasso (As mulheres expressionistas de Kooning versus Mademoiselles D'Avignon). Acima de tudo, o Expressionismo abstrato representava uma pintura do gesto, da ação, do 
gestual. Vejamos mais sobre esse assunto, nas considerações de Santaella e Nöth (1997, p. 146-147):

aspecto da singularidade é, de certa forma, inerente a qualquer pintura, na medida em que qualquer pintura, como original de um determinado artista, tem a marca desse pintor. No entanto, isso só aparece como aspecto dominante em imagens na qual a presença do pintor encontra-se totalmente em primeiro plano na forma do "gesto" específico. A action painting é o protótipo dessas imagens que funcionam como sin-signos, nas quais o vestígio da energia dos gestos pitorescos se mostra da maneira mais clara possível.

Esse período contou com a participação de um dos seus maiores críticos, o americano Clement Greenberg, que popularizou o termo "modernismo". Suas teorias, baseadas em Kant, levavam a crer que o que deveria ser exposto era aquilo que era único e irredutível, isto é, cada técnica artística deveria ser autorreferencial e diferente de todos os elementos exteriores, incluindo narrativa e ilusão, também capazes de mudar do abstracionismo para a essência universal.

\section{Jackson Pollock: quadro ação}

Com a Segunda Guerra Mundial, a corrente principal da arte moderna mudou dramaticamente. Os numerosos artistas europeus que procuraram refúgio na América exerceram uma influência profunda em pintores e escultores americanos mais jovens. Dessa colisão cultural emergiu um estilo cujas raízes estão no Cubismo e no Surrealismo, mas cujo olhar e significado são sem precedentes. $A$ arte moderna, mais especificamente a arte abstrata, era tida pelos críticos formalistas como um progresso em direção à pureza; no caso da pintura, isso significava um refinamento. Em dezembro de 1952, na edição de Artnews, Harold Rosenberg cunhara o termo action painting, o qual caracteriza artistas que, antes de tudo, vêem 
a tela como um espaço para a ação, sendo o mais renomado dentre eles Jackson Pollock. E assim, diz Rosenberg:

[...] num certo momento a tela começou a aparecer a um pintor americano como uma arena. Ao invés de um espaço para reproduzir, redesenhar, analisar, ou expressar um objeto real ou imaginário, esse espaço era para agir. $\bigcirc$ que estava na tela não era um quadro, mas um acontecimento, um evento. [...] $\bigcirc$ que mais importava era a revelação contida na ação. [...] A pintura, que é um ato, passa a ser inseparável da biografia do artista. [...] $\bigcirc$ gesto na tela era o gesto da liberação dos valores políticos, estéticos e morais. (ROSENBERG, 1952 apud FINEBERG, 1996, p. 96, tradução nossa)

Essa definição de Harold Rosenberg (1952) nos leva a entender que se tratava de uma pintura do gesto, da ação, uma pintura considerada gestual. O termo action painting (pintura do gesto), como parte do Expressionismo abstrato, passou a ser usado para descrever pinturas de pintores da School of New York, e estava associado ao Surrealismo europeu, à vida e à psique do pintor, e à materialização de suas ideias na tela.

Desse grupo de artistas voltamos nosso olhar para a obra de Jackson Pollock, que foi precursora da Performance e de outras práticas visuais, através do gesto. Mais uma vez, Santaella e Nöth (1997, p. 147) descrevem essa arte através da semiótica, exemplificando a singularidade na pintura de Pollock, que passa uma ideia da presença do "gesto". Segundo esses autores, nestas obras,

o vestígio da energia dos gestos pitorescos se mostra da maneira mais clara possível. As expressivas estruturas imagéticas das pinturas de Jackson Pollock não se referem a nada em nosso mundo a não ser aos gestos do pintor no momento da construção do quadro. As qualidades imagéticas deixam perceber o vestígio dos meios, dos instrumentos e da mão, que levaram à produção do signo. 
Durante os primeiros anos, Pollock revela um certo esforço em lidar com a arte europeia, particularmente com o Cubismo e o Surrealismo, como se eles fossem uma linguagem visual totalmente estranha à sua sensibilidade e, portanto, não podia acomodá-los às suas ambições. Um exemplo desse período é a obra Male and Female (1942), que apresenta duas figuras em forma de totem, simbolizando o homem e a mulher, que ocupam toda a tela. Como pintor do projeto do governo americano (o Federal Art Project), sua pintura começou a ser associada a várias influências: das pinturas de areia dos índios americanos, do pintor regionalista americano Thomas Hart Benton, dos muralistas mexicanos: Diego Rivera, José Clemente Orozco e David Alfaro Siqueiros, a alguns aspectos do Surrealismo. Deste último, destacam-se as teorias junguianas - decorrentes do método psicanalista do suíço Carl Jung -, sobretudo o conceito de inconsciente coletivo com base nas teorias surrealistas e no puro automatismo psíquico, e nos sonhos, a expressão direta do inconsciente do artista.

Entretanto, rapidamente, a pintura de Pollock tomou uma nova e determinada direção, e logo esse pintor passou a participar de exposições, como a mostra coletiva itinerante da galeria de Peggy Guggenheim (1948), que, além de Nova lorque, percorreu Veneza, Florença, Milão, Amsterdã, Bruxelas e Zurique. Nesse período, Peggy Guggenheim, sobrinha de Guggenheim, não mediu esforços para levar a arte de Pollock a vários espaços influentes. Ao abandonar o cavalete e adotar telas de grande formato (sem o uso de chassi), esse pintor introduziu o considerado all-over style na pintura, diferentemente da composição tradicional com pontos e ênfase de partes e relações entre elas, dentro do espaço pictórico; espaço que veio a ser denominado de arena, onde o corpo estava presente pela ação e pelo movimento.

Além de Peggy Guggenheim, como nos informa Danto (2007), Clement Greenberg, como o intelectual da época em Nova lorque, foi também um dos maiores responsáveis por legitimar a obra de Jackson Pollock, e ter identificado nesse pintor um mérito artístico, num tempo em que ainda havia resistência por parte de muitos críticos à arte abstrata. 
Outros críticos europeus, tal como David Sylvester, concederam em concordar com Greenberg sobre a superioridade da obra de Pollock.

Para Argan (2002, p. 531-532),

A action painting e o jazz são duas contribuições de imenso alcance dos Estados Unidos à civilização moderna: estruturalmente, são muito parecidos. [...] A action painting rompe com todos os esquemas espaciais da pintura tradicional. [...] Da mesma forma, na composição de um quadro de Pollock, cada cor desenvolve seu ritmo, leva à máxima intensidade a singularidade de seu timbre. Com Pollock, a pintura de ação americana aumenta de tom, atinge o ponto mais alto de sua parábola histórica.

Na pintura Autumn rhythm [Ritmo de outono] (1950), Pollock demonstra essa nova fase onde os planos com influência cubista são substituídos por outro espaço pictórico predominantemente linear. Entretanto, não se trata de uma simples linha; suas linhas possuem uma qualidade específica; elas correm o espaço pictórico dando uma ideia de paisagens aéreas, onde o horizonte é oculto. São linhas-teias, aceleradas, e não parecem fixas num plano, mas sugerem um movimento ótico. Trata-se de uma pintura que, muito embora apresente linhas, essas foram transportadas da lógica do desenho tradicional para a pintura.

Suas pinturas mais famosas datam do final da década de 1940 e início da década de 1950, período conhecido como drip period, cuja técnica de gotejamento, utilizando tinta líquida, Pollock aprendeu com o muralista mexicano David Siqueiros, em Nova lorque, na década de 1930. Ao optar pela tinta sintética, conhecida como gloss enamel, própria da pintura automobilística, Pollock estava adaptando sua técnica às condições do seu tempo, visto que esse tipo de tinta, durante a Segunda Guerra Mundial, era mais disponível e mais barato do que as específicas para arte, o que Pollock define como tendo sido um crescimento natural que veio de uma necessidade. Além desse tipo de tinta, Pollock usou outras fluidas ou empasto, adicionando areia e vidro moído para obter efeitos especiais. 
Para aplicar a tinta, substituiu pincéis tradicionais por utensílios domésticos, como colheres, facas e latas vazias com pequenos furos para executar gotejamentos de linhas extensas.

Ainda de acordo com Argan (2002, p. 531-532), "Pollock parte realmente do zero, do pingo de tinta, do pingo de tinta que deixa cair na tela. Sua técnica de dripping (gotejamento e borrifos de tinta sobre a tela estendida no chão) deixa certa margem ao acaso: sem acaso não há existência”.

Foi, portanto, através dessa técnica, que Pollock adicionou uma nova dimensão à pintura, ao desconsiderar a superfície ereta, uso de pincel e cavalete, bem como o modo tradicional de pintar com o uso da mão e do punho; desafiou e rompeu essa tradição, ao utilizar todas as partes do seu corpo com movimentos em várias direções na lona, como nos informa Nikos Stangos (2000, p. 129):

A postura de pintar à distância de um braço não pode ser mantida para uma pintura estendida no chão da mesma maneira que diante de um cavalete ou de uma parede. $O$ ponto de equilíbrio para Pollock passou a ser os quadris, e não, como antes, os ombros; o ritmo natural - e Pollock era um pintor "rítmico" desde o início tornou-se inevitavelmente mais expressivo, envolveu movimentos mais amplos e mais demorados da mão que controla a aplicação da tinta. Ele obteve maior controle da tela. Os ditames da gravidade e a fluidez maior da tinta asseguravam que uma pintura produzida dessa maneira estaria mais propensa àqueles efeitos “acidentais".

Por outro lado, Umberto Eco (1991a, p. 211), explicita que:

Num quadro de Pollock não nos é apresentado um universo figurativo acabado; o ambíguo, o viscoso, o assimétrico intervêm nele justamente para permitir que o impulso plástico-colorístico prolifere continuamente numa incoatividade de formas possiveis. Nesse oferecimento de possibilidades, nesse pedido de liberdade fruitiva, está uma aceitação do indeterminado e uma recusa da casualidade unívoca. 
O fato de permitir que a tinta manchasse a tela com latas perfuradas, segundo Pollock, era uma ação que ele associa ao movimento do seu corpo e o envolvimento com os pigmentos que eram controladamente calculados para obter o resultado desejado. Pollock afirmava ter conhecimento tanto sobre sua pintura quanto sobre as características de seu tempo. Em uma de suas entrevistas, ele revela:

Na minha opinião o novo pede novas técnicas [...] o pintor moderno não pode expressar sua época, o avião, a bomba atômica e o rádio com as mesmas formas do renascimento [...] o artista moderno está vivendo numa era mecânica [...] trabalhando e expressando um mundo interior - em outras palavras, expressando a energia, a emoção e outras forças interiores. (POLLOCK, 1950 apud FINEBERG, 1996, p. 89, tradução nossa)

Do mesmo modo que Stangos (2000) descreve a maneira de pintar de Pollock, um gesto incomparável e até então desconhecido na pintura, vários autores compartilham dessa definição. Sua pintura era construída como uma expressão corporal do pintor, também considerada uma dança, pelos movimentos realizados na tela estendida no chão. Tal associação deve-se também ao fato de haver, durante a década de 1950, a introdução da Performance com o grupo neoDada, em que a denominada estética do cotidiano foi recorrente, a união entre arte e vida.

Para Merce Cunningham (membro do neoDada), bailarino e coreógrafo americano, diretor da Companhia de Dança Moderna de Nova lorque no final da década de 1960, a dança não era apenas o tradicional ballet, mas qualquer tipo de expressão corporal, como andar, correr etc. Com coreografias abstratas, sem ligações simbólicas ou com argumentos, criou um estilo de dança experimental, a minimal dance. Daí os fortes indícios de que a pintura de Pollock foi a precursora da Performance, consequência desse período palpitante nas artes visuais que iniciava seu processo de hibridização com outras artes, como a dança, o teatro e a música. Portanto, a expressão "quadro ação" está adequadamente vinculada à maneira pela qual Pollock via 
o espaço pictórico e o espaço físico como uma relação indissociável. Suas últimas pinturas são também descritas por Fineberg (1996, p. 93):

Nas telas gotejadas, Pollock eliminou todos os símbolos e signos; apenas o gesto em si permaneceu como uma metáfora mítica. [...] Ele usou a técnica para expressar mais do que escavar; ele traduziu o ato de pintar em si em uma aventura de auto-realização. Quando Pollock disse a Hofmann em 1942 “Eu sou a natureza”, ele queria dizer que para ele o tema central da pintura derivava dessa exploração direta e introspectiva ao invés do mundo externo. Intuitivamente o observador pode sentir o processo pelo qual Pollock realizou suas composições com gotejamento e imaginar a sensação do livre movimentar-se por toda a tela com gestos de tinta. Finalmente, o observador deve recriar o sentimento dessa obra, porque a pintura é "sobre" o conteúdo introspectivo gravado nesses gestos. A pintura de Pollock requer que o observador encontre o controle intelectual enquanto possa ter uma empatia livre do movimento energético e colorido. (tradução nossa)

Não obstante a pintura de Pollock ter sido uma fonte de interesse para vários pesquisadores, a exemplo da possibilidade de sua arte incorporar padrões de fractais vistos no mundo natural, os campos pictóricos representam ambientes naturais de grande proporção que somente podem ser apreendidos à distância, ou seja, uma pintura cuja dimensão escapa ao espaço tradicional entre a obra e o observador. Esse tipo de distância é próprio de eventos ou acontecimentos, entre a teatralidade e o cotidiano, em que o limítrofe passa a ser expressivamente tênue.

Em 1958, Allan Kaprow declara sua admiração por Pollock, num texto escrito dois anos depois da morte de Pollock, intitulado The legacy of Jackson Pollock, atruibuindo a este pintor, a destruição da pintura, ao instaurar no ato de pintar o gestual, uma ação ritualística, ao pintar com pés, mãos, todo o corpo se movimentando sobre a tela. Kaprow acreditava que, a partir de Pollock, a pintura, e consequentemente a arte, havia experimentado elementos como espaço, movimento, a vida cotidiana e o corpo. 
Outras pesquisas consideram as pinturas de Pollock uma estética orgânica que pode se referenciar a condições atmosféricas e ciclos sazonais. Por outro lado, a necessidade do interpretante de encontrar um referente em qualquer pintura abstrata, leva a considerações mais próximas da relação existente entre $o$ interpretante e a obra, sobretudo a partir de títulos que funcionam como signos indiciais, tais como Ritmo de outono e Nevoeiro de alfazema, como uma espécie de reforço, assegurando a interpretação.

Em um extenso texto sobre a obra de Pollock, Schreyach (2007) discorre sobre as diversas proposições de estudiosos sobre a arte deste pintor, ao associá-la a fractais, influência da natureza, que para um interpretante seria impossível alcançar. Pois, as duas pinturas têm, incontestavelmente, características dissimilares do material e, portanto, efeitos perceptivos divergentes. Esta situação talvez leve à suposição errônea de que todas as pinturas têm, afinal, o mesmo significado. Então por que parece tão imperativo identificar seus significados? Talvez tenhamos um incômodo profundo com a tarefa aparentemente interminável que algumas pinturas abstratas exigem de nós: uma investigação vigilante e ininterrupta da nossa própria relação cultural com a natureza. Esta natureza, afinal de contas, talvez não seja facilmente dominada, mesmo quando podemos quantificar e poder contê-la no âmbito de um discurso científico ou humanísta.

\section{Paisagem dos Signos - Paisagem das Mídias}

No momento de transição entre os períodos Formalista e pós-Formalista, a arte surge patinando em terrenos escorregadios, e de certa forma desligando-se do seu referencial tradicional. Era um momento de perda de interesse pelas grandes narrativas, pelas grandes ideias e pela noção de grandes mestres, mas ainda predominava o modernismo.

O Expressionismo abstrato não provocava mais o mesmo impacto numa cidade (Nova lorque) que passava uma ideia de prosperidade marcada pelos meios de comunicação. Consequentemente, como a arte acompanha o desenvolvimento de seu próprio tempo, os artistas interessados 
nessa transformação cultural criam outras maneiras de representar uma paisagem carregada de imagens de consumo. Assim, a mudança de foco, do existencialismo para a semiótica, nas obras dos anos 1960, resultava da complexa realidade social e política dessa década.

Escritores como Lawrence Alloway (1974), juntamente a artistas e arquitetos eminentes, tiveram uma participação marcante nas discussões sobre essa emergente visão sígnica, que passamos agora a analisar.

O cotidiano e as sobras da sociedade de consumo denunciavam uma sociedade que voltara a consumir, uma cultura de massas latente, após a depressão que assolou a América nos anos 1930 seguida da Segunda Guerra Mundial. Estar diante de reflexões sobre os novos rumos dessa sociedade era estar, ao mesmo tempo, tentando adivinhar os novos caminhos pelos quais a arte trilharia, e consequentemente tal abordagem trouxe dificuldades para os críticos dessa época, sobretudo para o mais atuante deles, o americano Clement Greenberg.

Quando nos referimos a arte e paisagem, a primeira noção que nos aparece é a pintura, uma representação pictórica de campos, um recorte da natureza, gênero de pintura do Romantismo. Diferentemente, agora estamos diante de outro tipo de paisagem, denominado por Fineberg (1996) de paisagem dos signos, termo associado à introdução das imagens no cotidiano e às mudanças operadas pelos meios de comunicação. E como nos afirma Santaella (2007, p. 208), se "os signos se multiplicam porque o real é inexaurivel", esse período passou a ser um dos mais profícuos nesse sentido, sobretudo pela proliferação sígnica televisiva, ao considerarmos que as informações começam a invadir o espaço privado do homem através da televisão - que chegou a superar a casa dos quarenta milhões de aparelhos -, número significativo que chama a atenção dos teóricos dessa área. Essa máquina ganha força, ao apresentar, pela primeira vez, um presidente (John F. Kennedy) a milhões de famílias que, entusiasmadas pela possibilidade de ver a maior autoridade de seu país sem ter que se deslocar de seu sofá, passam a depositar confiança e credibilidade no conteúdo do que lhes era apresentado. 
A influência da televisão, portanto, exerce um impacto na maneira pela qual as pessoas enxergam o mundo. $O$ deslocamento das imagens, pelos meios de comunicação, para qualquer tipo de espaço, lugar e tempo, fez com que essas imagens causassem a impressão de estar permeando, flutuando em espaços diversos, especialmente e mais firmemente a mente das pessoas, como se fossem partes de um quebra-cabeça permutável.

Diferentemente de uma arte, que até então representava um mundo exterior ou o mundo interior do artista, estamos diante de um período artístico que apresenta fortes similaridades com as imagens dos meios da comunicação, visto que alguns artistas sentiam que não era mais suficiente dirigir sua psicologia pessoal para suas obras, tornando-se obcecados pela forma e pela linguagem próprias de uma criação que se conjugava à maneira pela qual a América havia se tornado uma cultura visual.

Além de paisagem sígnica, o termo the media landscape, usado por Stiles e Selz (1996), refere-se, do mesmo modo que ao espaço urbano moderno, transformado pela denominada coca-colonizing US mediatization, a uma ideia de paisagem como um ambiente crescentemente dominado por outdoors e propaganda. Um espaço onde publicidade, notícia, ficção científica, história em quadrinhos, revistas, comédias, televisão, cinema, filmes e celebridades haviam transformado uma sociedade, antes baseada no fazer e produzir coisas, para uma sociedade focada ou voltada para o consumo de imagens e informação.

Com o mesmo entendimento, John McHale (1996, p. 282) já expressava o desejo de artistas e intelectuais, no início desse período, pois, segundo ele, "a transmissão, aplicação e transformação das artes plásticas, agora transmitidas dentro de uma pluralidade de mensagens e inseridas em diferentes vocabulários culturais, são meramente parte do processo de difusão da vida cultural" (tradução nossa), que ocorria numa infinita variedade de meios.

Vejamos como Santaella (2005, p. 72), descreve como os meios de comunicação de massa e os meios de produção artística se autoinfluenciam, ou seja, se hibridizam: 
Por exemplo, o cinema mistura som, imagem, diálogos e figurinos. Isso leva à facilitação da comunicação ao se reforçar o significado através de uma relação intersemiótica. As "belas artes", ou seja, a pintura, a escultura e a música, foram se transformando e perdendo seu caráter de pureza, ao incorporarem máquinas reprodutoras de linguagem e ao utilizarem dispositivos tecnológicos de produção. Esse uso em comum dos meios de produção entre os meios de comunicação e os meios artísticos deve-se em grande medida à apropriação pelos indivíduos dos dispositivos tecnológicos da cultura das mídias, bastante diferente da lógica da comunicação de massa. $\bigcirc$ acesso facilitado a esses equipamentos deu origem a novas formas de arte tecnológica, inaugurando uma nova época nas artes, as quais, através do experimentalismo, foram moldando um novo olhar artístico, mais identificado com a contemporaneidade.

Sendo o principal centro das artes desde 1930, a cidade de Nova lorque dos anos 1960 teve como um dos focos o incentivo ao crescimento industrial, tecnológico e da sociedade de consumo, com a participação da propaganda eletrônica, dos luminosos de gás néon, dos fast foods etc. Portanto, houve uma intensa dedicação ao poder de comunicação da imagem, a qual foi investigada ao extremo como forma de comunicação de massa. Um dos mais contundentes exemplos é "o palhaço feliz", símbolo da McDonald, que apareceu na TV, em 1963, juntamente aos astros de Holywood, comidas enlatadas, todos integrantes de uma rede semiótica que em muito interessou os artistas da Pop Art.

Vale ressaltar que essa maneira de ver o progresso econômico estava associada a um acompanhamento estreito dos princípios estéticos dos produtos, por meio do design gráfico e industrial. Portanto, a valorização da mídia, associada ao estudo dos signos, e a explosão imagética não foram ocorrências arbitrárias. Nas artes plásticas, quem mais desfrutou desse período por ter consciência do que se tratava, ou seja, a linguagem dos meios gráficos e da publicidade, foi o artista americano Andy Warhol, considerado por vários teóricos, como Robert Hughes (1999), como sendo 
o produto desse meio. Hugues (1999, p. 49) o associa ao mito de Narciso, ao dizer que:

garoto de classe média que gastou muitas horas olhando para o azul anestesicamente resplandecente da tela de TV, como Narciso no seu lago, entendeu que o momento cultural dos meados dos anos 1960 favorecia um caminhar pelo vazio ambulante. A televisão estava produzindo um efeito cultural sem emoção, portanto, foi nesse cenário que Warhol tornou-se o herói da falta de emoção. (tradução nossa)

Esse novo narciso, considerado por Hughes (1991), como aquele que já não olha para o seu lago, mas para um azul eletrônico, é fruto de uma camada social na qual a televisão desempenha um poder de transmissão de informação, e sobretudo de entretenimento. Mas, ao mesmo tempo, a experiência visual adquirida através dessa máquina, que lhe era familiar, juntamente à experiência técnica que Warhol desenvolveu como profissional da área do design gráfico e da técnica de embalagem, serviu, indubitavelmente, como passaporte para sua entrada no mundo artístico.

Durante a Pop Art, a vanguarda era uma ideia, bem como uma realidade cultural, conforme nos afirma Hughes (1991, p. 53, tradução nossa). De fato, nessa época, a vanguarda estava perdendo espaço no cenário artístico, devido ao crescimento do mercado financeiro, bem como pela total predominância do público de classe média, mais interessado na televisão. A ênfase na interação entre o artista e a sociedade não interessou a todos, de uma forma mais abrangente, em função de certa escassez de julgamentos críticos que satisfizessem leitores mais interessados no mérito estético.

Carlin e Fineberg (2005) apresentam as concepções de alguns artistas que retrataram, visual e artisticamente, as principais mudanças que configuravam em uma nova forma a vida americana, através de ideias de escritores, como Emerson, Pynchon e McLuhan.

No catálogo da exposição "Image World: Art and Media Culture", realizada no Whitney Museum, em 1989, Marvin Hierferman, um dos 
curadores dessa exposição, comentou que os artistas se confrontavam no seu dia a dia com um amontoado de imagens e tinham que lidar com esse fato. Um anúncio exposto na entrada enumerava os seguintes dados:

Esta manhã, 260.000 outdoors enfileirarão os caminhos que levam as pessoas ao trabalho. $\grave{A}$ tarde, 11.520 jornais e 11.556 periódicos estarão disponíveis à venda. E quando o sol se puser novamente, 21.689 teatros e 1.548 drive-ins projetarão filmes; 27.000 lojas de vídeo alugarão filmes; 162 milhões de aparelhos de televisão ficarão ligados por 7 horas: e 41 milhões de imagens serão fotografadas. $E$ amanhã, haverá mais. (HIERFERMAN, 1989 apud SANDLER, 1996, p. 320, tradução nossa)

Igualmente, Santaella (1983, p. 12), tece considerações sobre este assunto, ao informar que, na era pós-revolução industrial, "as invenções de máquinas capazes de produzir, armazenar e difundir linguagens (a fotografia, o cinema, os meios de impressão gráfica, o rádio, a TV, as fitas magnéticas etc.) povoaram nosso cotidiano com mensagens e informações". E tudo isso nos diz que estamos diante de um período permeado por signos, seja no cotidiano, seja nas artes. Contudo, ao atentarmos para esse fato, devemos nos voltar para o paradigma desse encontro, arte e cotidiano, mais especificamente ao que podemos considerar como estética da marca.

Ora, se um signo tem a intenção de representar um objeto (ou partes dele) através da mediação de um signo (entre um objeto dinâmico e um interpretante final), nas artes visuais podemos ilustrar isso a partir de qualidades, próprias da categoria da primeiridade. Isto é, sensação provocada pelas cores, pelas formas, textura etc. E nesse caso, os signos da pintura, em princípio, são essas qualidades, o quali-signo. No entanto, essa arte que surge carregada de signos híbridos é, ao mesmo tempo, uma arte que mistura suas qualidades de sensações (da categoria da primeiridade) com signos indiciais e simbólicos que revelam o comportamento de uma cultura. Isto nos leva a refletir sobre as colocações de Santaella (2000a, p. 150), relativas à presença do hábito estético, ou seja, se por um lado 
a mudança de hábito nas artes se dá por meio da experiência estética e da qualidade de sentimentos, nos meios de comunicação esse hábito é perseguido pela mudança de comportamento do homem na sociedade em que ele vive e que envolve, também, o hábito do consumo. Os signos crescem, e na medida em que eles alcançam a categoria da terceiridade, do conhecimento, inteligibilidade, eles estão no processo de semiose, de crescimento para gerar novos signos. $O$ prazer estético é pura sensação de qualidades. Então como podemos definir essa qualidade presente nas artes visuais e nas imagens dos meios de comunicação?

Retomando outras considerações de Santaella (2005), a Pop Art não está preocupada com a representação da natureza, mas da realidade urbana. A arte propõe relações de ambiguidade com a cultura de massas, é uma celebração da cultura americana, mas apresenta, ao mesmo tempo, um tom crítico ao crescente consumo. Não se trata de uma mera apropriação de imagens e objetos do cotidiano, mas de uma tradução semiótica, um modo de recontextualizar. As relações dicotômicas entre arte maior e arte menor, presentes no mundo da cultura por vários séculos, que excluíam todas as práticas que não fossem pintura e escultura, bem como os materiais tradicionais, nos levam a refletir e ver a arte contemporânea por outros ângulos.

Para Santaella (2003a, p. 52-55),

Até meados do século XIX, dois tipos de cultura se delineavam nas sociedades ocidentais: de um lado, a cultura erudita, das elites; e de outro lado, a cultura popular, produzida no seio das classes dominadas.

$[\cdots]$

O advento da cultura de massas a partir da explosão dos meios de reprodução técnico-industriais - jornal, foto, cinema -, seguida da onipresença dos meios eletrônicos de difusão - rádio e televisão -, produziu um impacto, até hoje, atordoante, radical dessa cultura. 
Ademais, a Pop Art não esgota nem estanca esse processo de transposição de imagens dos meios de comunicação para a arte, mas, sobretudo, injeta nos artistas uma maior consciência dos objetos que permeiam o seu cotidiano, seja na linguagem escrita, seja na mídia televisiva e, mais tarde, na mídia digital. Quanto à arte, não obstante sob fortes índices de outros meios, ela continua a desfrutar de sua iconicidade, de pura liberdade, inclusive para tomar outros rumos.

\section{Arte Cinética: 0 espaço na obra de Calder}

A arte concreta refere-se às obras abstratas da tradição construtivista, elaboradas por artistas que aspiravam erradicar a representação e a subjetividade da arte. Essa busca pela objetividade refletia as teorias de Theo van Doesburg, que, em 1930, definiu uma arte de absoluta clareza e técnica mecânica precisa. Seis anos mais tarde, Max Bill denominou essa arte, objetiva e abstrata, intimamente relacionada à matemática, de arte concreta. Fruto de um dos mais idealistas movimentos artísticos do século XX, de Stijl, foi também o mais puro dos movimentos abstratos, de origem e essência dos Países Baixos, em 1917, um marco na arte moderna. Durante o seu auge, entre os anos 1921 e 1925, exerce uma influência notória em diversos tipos de obras contemporâneas. Ao injetar sólido embasamento teórico na criação - pinturas, construções, esculturas etc. -, os neoplasticistas radicalizaram e renovaram a arte desse período, baseando-se no modo pelo qual eles entenderam um novo espaço que não era necessariamente limitado às artes plásticas.

Com o intercâmbio entre esse movimento e a Bauhaus, o ideal neoplástico tornou-se imensamente popular, com produção e consumo, em escala industrial, de infindáveis peças diretamente inspiradas pelas propostas do grupo holandês, que adquiriam um caráter moderno, voltado para o futuro. Por sua vez, a Arte Cinética, que atingiu seu ápice durante os anos de 1950 a 1960, foi uma expressão que representou essencialmente a arte em movimento, em que os artistas queriam expor a força e o poder 
desse elemento, enfatizando a iluminação e a tecnologia, e demonstrando um total desinteresse por temas e ferramentas artísticas, como pincéis e tintas. Com base no Futurismo, essa arte influenciou artistas do período pós-Formalista, como a Laser Art e a Arte e Tecnologia Digital, do final do século $X X$ e início deste novo milênio.

Destacamos Naum Gabo (escultor, arquiteto, teórico e professor russo), o escultor e pintor russo Antoine Pevsner, Laszlo Moholy-Nagy e Alexander Calder, um dos mais atuantes desse segmento artístico. Quando a Arte Cinética emergiu nos anos 1950, o movimento pareceu dar ênfase a um certo significado de como esses artistas criavam esculturas. A maioria deles, inicialmente, começou através do movimento, mas, muito mais tarde, deu início a novas experiências com a luz e o espelho, misturando a forma humana em sua criação, o que provocava um tipo de sensação até então não investigada nas artes plásticas. As obras que exploravam espelhos e luz convidavam o espectador a adentrar os espaços; envolver-se com eles e complementar a obra como coparticipante. Por se tratar de um espaço labiríntico, as luzes refletiam imagens, e o observador perdia a noção do seu próprio corpo, espaço e tempo, evidenciando, com isso, o objetivo do labirinto em manter a pessoa perdida. Como resultado desses experimentos, estabeleceu-se uma nova relação entre obra e público: a aproximação com o objeto, eliminando a distância e superando a mera contemplação do olhar, uma proposta de participação que incluía todo o corpo do espectador.

É nesse contexto que a obra de Alexander Calder se caracteriza, sendo relevante neste livro como referência à noção de espaço-tempo, muito embora o enfoque sobre os materiais utilizados não seja omitido. Em depoimentos sobre sua obra, algumas observações de Calder (apud FINEBERG, 1996, p. 46) são esclarecedoras do funcionamento das suas esculturas, como a seguir:

O sentido subjacente de forma em meu trabalho tem sido o sistema do universo, ou parte disso. [...] $\bigcirc$ que eu quero dizer é que a idéia de corpos desprendidos, de tamanhos e densidades diferentes, talvez 
de diferentes cores e temperaturas, flutuando no espaço, cercados por espirais de condição gasosa, alguns em descanso, enquanto outros se movem de maneira peculiar, parece para mim a fonte ideal da forma. (tradução nossa)

Alexander Calder sempre explicitou a influência que o cosmos teve no seu trabalho - um interesse que surgiu desde sua infância -, a exemplo da obra Universes series, inspirada em conceitos matemáticos; nada mais do que normal para um artista com formação em engenharia.

Mesmo depois de abandonar sua profissão de engenheiro e começar a estudar arte, Calder manteve uma fascinação (expressão comumente usada por ele) pelos modelos do sistema planetário do século XVIII (orreries), motivado pela experiência adquirida durante o tempo em que trabalhou em um navio. Durante uma viagem realizada entre Nova lorque e São Francisco (EUA), através do canal do Panamá, à noite, trocava sua cabine pelo convés e dormia admirando o céu. Foi quando observou um fenômeno natural, um dos momentos mais inspiradores, que ele assim descreve:

Numa manhã cedo no mar tranqüilo, fora da Guatemala [...] Eu vi o começo de uma alvorada vermelha inflamável de um lado e a lua parecendo uma moeda de prata do outro. Durante a viagem inteira isto me impressionou; deixando-me com uma sensação durável do sistema solar. (CALDER apud FINEBERG, 1996, p. 45 , tradução nossa)

No início do século $X X$, as teorias de Albert Einstein sobre a relatividade estabeleceram conceitos básicos de tempo, espaço e gravidade, que se tornaram fundamentos da física e da astronomia. A teoria essencial de Einstein sobre a experiência de espaço e tempo passou a interessar artistas do movimento concreto, que baseavam a estrutura de suas pinturas abstratas em princípios científicos. Como nos afirma Peirce (2005), tanto a arte como a matemática são signos icônicos. Enigmática e sedutora, a 
arte encantava os cientistas, sobretudo quando nela eles encontravam algumas aproximações a suas teorias. Um dos exemplos artísticos mais relevantes do século passado é o encontro de Albert Einstein com a obra de Alexander Calder.

Ao visitar a exposição desse escultor, realizada no New York Museum of Modern Art, em Nova lorque, em 1943, Albert Einstein passou 45 minutos em frente à obra $A$ Universe. Calder logo entendeu que Einstein estava esperando a repetição das combinações para que ele pudesse analisar a proporção das diferentes partes, o que o encantou. Entre uma combinação de movimentos e outra, Calder fez um cálculo de aproximadamente 90 ciclos, para cada combinação, cada uma com a duração de 45 minutos. Ao chegar a esta conclusão, Einstein murmurou: "Eu gostaria de ter pensado sobre isto antes”. (EINSTEIN apud FINEBERG, 1996, p. 48, tradução nossa)

A invenção do móbile por Calder, em 1930, foi uma das primeiras inovações no campo da escultura, pois, segundo Fineberg (1996, p. 48),

Essa invenção incorporou literalmente dentro da escultura: tempo (a quarta dimensão), movimento, e variações relativas de velocidade e distância entre os componentes das partes. A noção de tempo-espaço-conceito de continuidade - preocupação principal do avanço da ciência em 1905 - estava integrada com os interesses de Calder na Cosmologia. (tradução nossa)

A escultura, até então, estava fundamentada na presença do pedestal ou outro suporte que a assentava ao solo de uma maneira fixa, distanciando o espectador do espaço real, como se fosse uma moldura que envolve o quadro. Ao colocar sua obra flutuando livremente no espaço, ocupado também pelo espectador, Calder conseguiu traduzir plasticamente a frase de Vladimir Tatlin: "materiais reais no espaço real" (FINEBERG, 1996, p. 48, tradução nossa), o que foi denominado de open-form sculpture.

Eco (1991a, p. 153), reconhece a importância da obra de Calder para a escultura moderna, ao afirmar que 
Calder dá um passo à frente: agora a própria forma se move sob nossos olhos e a obra torna-se 'obra em movimento'. Seu movimento compõe-se com o do espectador. A rigor jamais deveria haver dois momentos, no tempo, em que a posição recíproca da obra e do espectador pudesse reproduzir-se de modo igual. O campo das escolhas não é mais sugerido, é real, e a obra é um campo de possibilidades.

Alexander Calder atribui alguns dos seus conceitos de movimento a Marcel Duchamp, ao Futurismo italiano, ao Cubismo e ao notório Ballet Mécanique, de Fernand Léger, associado a terminologias científicas que explicam seu método de construção cinética. $\mathrm{O}$ interesse de Calder pelo arame o acompanha desde a sua infância, quando confeccionava joias para as bonecas de sua irmã, material que utilizou por muitos anos, já como artista. As primeiras esculturas, portanto, foram consideradas desenhos tridimensionais, basicamente portraits de amigos, animais ou personagens de circo e joias. Para Calder, todo o universo, com sua variedade de formas botânicas, possui um sentido de movimento natural perpétuo.

Quando foi viver em Paris, esse artista montou um circo, composto por animais feitos de arame, movimentados manualmente, o qual ele apresentava em seu apartamento, cobrando inclusive ingressos. Segundo Fineberg (1996, p. 45), este foi um tipo de evento frequentado pela vanguarda parisiense. Durante o período em que viveu na França, Calder teve a oportunidade de conhecer vários artistas, tendo sido Piet Mondrian o mais influente em sua carreira, e, mais especificamente, através de uma visita ao atelier desse pintor, em 1930, foi que Calder se aproximou da arte abstrata. Nessa visita, o ambiente lhe causou curiosidade, propiciando o diálogo, assim descrito:

Era uma sala muito estimulante. A luz penetrava pelos dois lados, e presos à parede sólida entre as janelas havia pedaços experimentais com retângulos coloridos feitos de papelão. Até mesmo a vitrola, que deveria ter sido originalmente de uma cor lamacenta, fora pintada de vermelho. Eu sugeri a Mondrian que talvez fosse mais 
interessante fazer com que os retângulos oscilassem. E ele, seriamente, disse: 'não, não é necessário; minhas pinturas já possuem muito movimento' [...]. Esta visita provocou em mim um interesse para começar a fazer coisas. Embora eu tenha sempre ouvido falar na palavra 'moderno', até então eu não conhecia ou sentia conscientemente o termo 'abstrato'. Assim agora aos 32 anos de idade eu quero pintar e trabalhar com a abstração. (CALDER apud FINEBERG, 1996, p. 45, tradução nossa)

Foi, portanto, a partir de então, que, pela primeira vez, Calder entendeu o significado da arte abstrata, dando início à construção das suas conhecidas esculturas: móbile e stabile. $O$ nome móbile, cunhado por Marcel Duchamp, a pedido de Calder, refere-se a algo que se move. Quanto aos stabiles, nomeiam esculturas fixas, de grande porte, expostas ao ar livre. A influência de Mondrian nas esculturas de Calder tornara-se visível, com o uso de cores primárias, "especialmente o vermelho - em oposição ao preto e ao branco, uma preocupação com o equilíbrio do espaço e da superfície, e uma ideia de balanço assimétrico". [Além da parte formal, Calder entendeu o caráter da obra de Mondrian na] "correlação da forma e metafísica”. (FINEBERG, 1996, p. 46, tradução nossa)

A construção de suas obras segue um método rigoroso e preciso, desde o estudo do local em que elas vão ocupar até à realização de maquetes e ao levantamento do material que se adapte às formas previstas. Seus trabalhos de grande porte foram acompanhados por engenheiros e arquitetos, sempre, contudo, sob sua direção. Uma de suas últimas peças, que data de 1971, realizada para a National Gallery of Art, foi assessorada pelo arquiteto leoh Ming Pei, mais conhecido como I. M. Pei. Nela, o aço, tradicional na obra de Calder, foi substituído pelo alumínio de honeycombed, um material novo naquela época, extremamente leve e de maior duração, originalmente desenvolvido para a aeronáutica. A utilização desse material aumentou a capacidade dos móbiles em relação às correntes de ar. Infelizmente Calder não pôde testemunhar o êxito desse material, mas sua arte deixou, como um legado para o conhecimento 
humano, um testemunho incomensurável: o uso do poder da fonte natural que deu movimento às suas esculturas, uma fonte que ele encontrou à sua disposição diretamente na natureza, um movimento causado pela lei da gravidade, pelo vento e outras forças naturais. 


\section{REPENSANDO A REPRESENTAÇÃO}

No livro Art after modernism: rethinking representation (1991), o editor Brian Wallis leva-nos a refletir, segundo uma estrutura de referência crítica, sobre a representação e os principais conceitos que se descortinam sobre a arte depois do modernismo. Trata-se de uma antologia (palavra grega

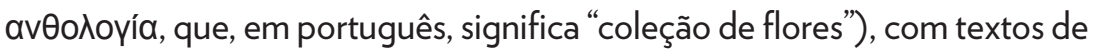
diversos teóricos, a exemplo de Abigail Solomon-Godeau, Craig Owens, Douglas Crimp, Frederic Jamenson, Hal Foster, Lucy Lippard, Martha Rosler, Michel Foucault, Roland Barthes, Walter Benjamin, dentre outros. Embora alguns desses autores não sejam contemporâneos do período estudado, suas teorias, não obstante, possuem um espírito atual, como 
Walter Benjamin, considerado um clássico do século XX. Assim, com base nesses teóricos, propomos ampliar um diálogo, nos textos subsequentes, com outros pesquisadores que comungam do mesmo pensamento.

\section{Do Moderno ao Contemporâneo}

Para Danto (1997a), a mudança do período pré-modernista para o período modernista pode ser entendida, através de Clement Greenberg, como uma mudança da pintura mimética para a não-mimética, quando a característica representacional tornou-se secundária. Com isso, a tela, o plano da tela, sua bidimensionalidade, o uso de tubos ou potes de tintas, a ausência da perspectiva etc. tornam-se mais importantes. A partir da compreensão de um possível encadeamento na história da arte, o modernismo tornase um marco, pois, antes dele, os pintores representavam o mundo da maneira como eles o apreendiam, através de seus próprios olhos. Neste sentido, a pintura não foi vista como um tipo de descontinuidade, como uma representação mimética menos importante do que algum tipo de reflexão sobre outros meios e métodos de representação. E neste cenário artístico, alguns conceitos que passam a delinear a contemporaneidade emergem de obras de artistas, com o uso de novos materiais e a ruptura com o espaço lógico das artes plásticas. Nos subcapítulos que se seguem, daremos ênfase a alguns desses momentos paradigmáticos.

De acordo com Danto (1997a, p. 11), a "arte contemporânea” teria sido somente a "arte moderna", o que estava sendo feito durante esse tempo, pois moderno, afinal de contas, implicava em uma diferença entre o momento atual e aquele que havia passado. (tradução nossa) Assim, não haveria nenhum uso para a expressão "arte contemporânea", se as coisas permanecessem constantes e em grande parte as mesmas. Isso implica uma estrutura histórica que é mais forte, neste sentido, do que um termo como "mais recente". O contemporâneo, no seu sentido mais óbvio, é simplesmente a arte produzida por nossos contemporâneos. Mas como a história da arte desenvolveu-se internamente, "contemporâneo" 
passou a ser entendido como uma arte produzida no âmbito de uma certa estrutura de produção nunca vista até então na história da arte. Não se referia a algo mais moderno, no sentido de "o mais recente", e o moderno parecia, cada vez mais, ter sido um estilo que prosperou de 1880 até 1960, aproximadamente. $\mathrm{O}$ mesmo pode ser dito sobre a arte moderna, que continuava a ser produzida depois disso; a arte que permaneceu sob o imperativo estilístico do modernismo; mas essa arte realmente não seria contemporânea, exceto no sentido estritamente temporal desse termo.

Segundo Adams (1966), a análise formalista é basicamente o efeito estético criado pelos componentes da composição plástica, através de elementos visuais, como a linha, a forma, o espaço, a cor etc. Diferentemente, o período pós-Formalista, através de suas inúmeras e diversas práticas visuais, não comportava apenas esse tipo de análise (formal) e a ela se adicionaram outras perspectivas analíticas, como apropriação, iconologia e iconografia, marxismo, feminismo, biografia e autobiografia, semiótica (estruturalismo, pós-estruturalismo e desconstrução), psicanálise etc.

Contudo, nesse período, torna-se difícil hierarquizar classificações, visto que, por se tratar de uma arte que busca a instabilidade, o rompimento com conceitos fixos e predeterminados - por conseguinte, a não linearidade -, o próprio discurso e o texto devem se conformar a essas condições. Os significados se aproximam uns dos outros, e, a depender de sua aplicação, alguns podem até se sobrepor. Desse modo, algumas estratégias vão ser inicialmente apresentadas, enquanto abordagens (etimológica e epistemológica) do termo, e as associações às artes visuais surgirão em contextos mais específicos, pois elas necessitam de uma contextualização particular que justifique sua aplicação. Assim sendo, as repetições que por ventura venham a surgir fazem parte da característica labiríntica desses próprios conceitos. No entanto, antes de avançarmos, é importante refletir sobre algumas questões que frequentemente vêm à tona: como se dá e o por quê da presença desses conceitos nas artes visuais? Como eles são entendidos e aplicados? É justamente a partir dessas indagações que as teorias filosóficas devem ser estudadas e cautelosamente aplicadas às artes visuais, sem que haja, em princípio, a precipitação de transportá-las, 
de imediato, sem um conhecimento antecedente de seus significados. Os conceitos não podem servir como meros temas ou apêndices ilustrativos, porquanto as artes visuais não podem estar a serviço de quaisquer teorias. Nunca é demais lembrar que a arte é exclusivamente um signo livre, um ícone. Portanto, esses conceitos filosóficos são instrumentos para serem pensados à luz de determinados aspectos presentes nas obras.

Nesta investigação, em particular, trata-se de um estudo sobre a natureza da arte, ou seja, como a obra vem sendo construída a partir do final do século XIX, e a transposição de seus elementos constituintes (lógicos) tradicionais. Desta maneira, essas proposições nos ajudam a pensar em conceitos que estão em consonância com mudanças pelas quais a arte passou durante esse período. Assim como a pintura, inicialmente, a escultura e a fotografia, na sequência, se deslocaram de seu estado essencialmente técnico, material, funcional, tradicional, ou seja, do seu estado predominantemente fixo, estável, puro, dando origem a diversas linguagens visuais, e a teoria da arte passou, então, a compartilhar de uma fresta que, ampliando-se cada vez mais, impregnou-a, crescentemente, de alguns conceitos característicos de outras áreas afins do conhecimento humano. Deste modo, são recorrentes na teoria da arte termos que definem o pensamento contemporâneo, pelo qual nada pode ser preconcebido como primeiro, único, verdadeiro. E para melhor ilustrar este assunto, escolhemos os mais presentes nas artes visuais, a partir dos anos 1970 e até a nossa atualidade, que serão apresentados na sequência.

\section{Desconstrução}

Ao aliar todo um conceito de contexto cultural à concepção de arte, a contemporaneidade traz consigo uma nova maneira de observar e refletir sobre a criação artística, e, no âmbito de seus territórios, ela reconhece como válidos os mais diversos meios de representação, desde os mais tradicionais até às inovações que ganharam notoriedade, a partir dos anos 1960 e 1970.

Ao falar sobre representação e reprodução, Danto (1998, p. 119) observa que a arte chegou ao seu fim quando ela alcançou o sentido filosófico 
de sua própria identidade, e quando, então, surge uma questão que ele considera épica. Épica, pois, no século XIX, a pintura desempenhou um papel de relevância na representação. Era de sua competência representar. Somente a ela era determinado esse papel. Entretanto, mais tarde, com o advento da imagem fixa, e em seguida da imagem em movimento, dois fatores foram identificados: um referente ao aspecto tecnológico e, o outro, ao cultural. Por outro lado, a necessidade de representação no modernismo foi substituída por outro tipo de concepção, até então marcada pelas teorias de Clement Greenberg, durante décadas do século XX, que declara:

\begin{abstract}
A área rara e adequada de competência de cada arte coincidia com tudo que era raro na natureza de seu meio. [...] Assim, o que existia de "puro" e "pureza" em cada arte encontrava a garantia de seus padrões de qualidade assim como sua independência. A "pureza" quis dizer autodefinição, e a empresa de autocrítica nas artes tornou-se uma autodefinição com vingança. (GREENBERG, 1960 apud DANTO, 1998, p. 121, tradução nossa)
\end{abstract}

Essa concepção de Greenberg vai perder sua força, a partir de 1970, período que Danto (1998, p. 121) denomina de "pós-histórico" ou de "pluralismo objetivo", época em que a abstração é vista como um campo de possibilidades e não mais de necessidade. Um campo no qual nada é necessário nem obrigatório.

Para Greenberg (apud DANTO, 1998) as artes entraram na sua fase terminal, quando cada uma delas fez sua ascensão sob o mandato da própria metalinguagem e quando os materiais da arte tornaram-se o único assunto adequado. Assim, a escultura seria a pedra ou o barro que se modela. A pintura estaria sobre a tinta e o ato de pôr as tintas sobre superfícies (tradução nossa). Essa fase terminal deu-se através da crise da representação, explicitada por Santaella (2003a, p. 145), a saber:

Se a fotografia havia inaugurado, no mundo da linguagem, a era da reprodução, provocando a crise da representação, levada a efeito pela 
história da arte moderna, Duchamp antecipatoriamente pôs termo a essa era, antevendo o esgotamento do dilema entre figurativo vs. não-figurativo, no terreno da arte e fora dele, assim como levou o questionamento dos suportes das artes até o limite de sua dissolvência. É por isso que, no universo da cultura e das artes, com suas antevisões de futuro, Duchamp é uma espécie de rito de passagem: ponto em que a era mecânica industrial sai de seu apogeu, dando início à era eletrônica, pós-industrial. É por isso, também, que a arte pop, na sua reação ao desmesurado crescimento dos meios e produtos da cultura de massas, não foi senão a explicitação de uma atividade estética inseparável da crítica que já estava implícita em Duchamp.

Santaella e Nöth (1997, p. 22) consideram a crise da representação um assunto recorrente no século $X X$ e que tem atraído o interesse de vários teóricos, que "discutem temas bastante variados. Foucault sobre a perda da representação e a tese de Derrida sobre a impossibilidade da representação". Dando continuidade a essas colocações, vejamos o pensamento desses autores, a seguir:

De acordo com a filosofia da presença de Derrida, a representação não pode ser uma presentificação no sentido de uma repetição de algo presente anteriormente. Ela "não é a modificação de um acontecimento de uma apresentação original” (Derrida 1967: 50). Por um lado, o representado mesmo é um signo, "pois a representação deve representar uma apresentação enten dida como imaginação." [...] Por outro lado, cada repetição ou iterabilidade do signo já significa a modificação deste signo em um processo, no qual não pode existir nem uma primeira nem uma última vez. Portanto, a diferenciação "entre a simples presença e a repetição sempre já começada deve ser apagada". Derrida opõe à idéia da presença fenomenológica, como último ponto de referência da representação, seu conceito da différance, e isto significa o adiamento infinito da presença e a diferença inanulável dentro do signo que, dividido em si mesmo, leva consigo vestígios de outros signos. (SANTAELLA e NÖTH, 1997, p. 25) 
Igualmente, Newman (1991) sublinha que a representação foi desconstruída, ou seja, continuou presente, mas de uma forma crítica: quando passou a ser entendida como desvinculada do real, a representação era uma coisa e o real outra.

Para alguns teóricos, sobretudo os pesquisadores americanos, a desconstrução é uma análise derivada da semiótica, que revê a multiplicidade dos significados potenciais gerados pela discrepância entre o conteúdo ostensivo do texto, o qual pode ser um trabalho de arte, e o sistema visual de limites, cultural e linguístico, do qual ele nasce. Desconstrução é também um termo da filosofia contemporânea, da crítica literária e das ciências sociais, que denota um processo pelo qual o texto e a linguagem da filosofia ocidental (em particular) mudam de sentido quando são lidos à luz das suposições e ausências que ambos revelam dentro de si.

Sarup (1989, p. 35), sugere que "para entender a obra de Derrida o conceito mais importante que deve ser considerado é 'sous rature'", termo usualmente traduzido como sob rasura, e conceito que foi usado primeiramente por Martin Heidegger, "que sempre cruzava a palavra ser com um $\mathrm{X}$, o que significava estar presente e ausente, ao mesmo tempo [...]; [indicando que] "essa palavra era igualmente inadequada e necessária". (tradução nossa) Já Derrida (apud SARUP, 1989, p. 36) nos diz que a estrutura do signo é determinada pelo rastro (o significado francês que carrega implicações de pista, pisadas e impressões). (tradução nossa) O conceito derridiano visa rever a noção de plenitude do presente, da pureza da origem, ou da autoidentidade do absoluto. Essas primeiras preocupações indicam um engajamento desse conceito com a metafísica, e, indubitavelmente, trata-se de um conceito complexo, do qual Jacques Derrida, em Of grammatology (1976), faz um extenso estudo, e prefere explicar através daquilo que o termo não é. Portanto, vejamos a seguir.

Esse termo não consolida uma análise, uma crítica, nem um método, no seu sentido tradicional. A complexidade colocada no entendimento do seu significado reside, justamente, na sua própria característica, ou seja, se o termo não é algo, por outro lado, ele não nega a existência desse algo, pois, segundo Sarup (1989, p. 36) é preciso "retornar a ele, ao menos sob rasura" 
(tradução nossa). Portanto, ele deve ser entendido como uma impossibilidade de determinação de significados fechados. Derrida (1976) propõe que a dicotomia seja problematizada e não superada, como meta a resolver, de uma só vez, todos os problemas que são encontrados no caminho do raciocínio, pois este seria nada mais do que o velho desejo de soluções definitivas. Sua proposta não inclui a acomodação do pensamento através de uma conclusão, a satisfação em alcançar uma verdade. Tal acomodação deve ser substituída pelo exercício de um pensar constante, rompendo com as dicotomias, sendo as mais conhecidas, dentre várias: identidade versus diferença; sujeito versus objeto; fala versus escrita; presença versus ausência. Derrida (1976) vê a dicotomia como uma maneira de privilegiar o primeiro termo, esse, portanto é considerado como sendo o original, autêntico e superior, enquanto o segundo é pensado como secundário, derivado. De Man (1982, p. 510) vem a concordar com Derrida (1976), ao evidenciar que:

Quando se analisa ou desconstrói um par de termos binários, o que está implícito não é que tal oposição não tenha validade alguma numa situação empírica (ninguém de bom senso poderia sustentar que seja impossível distinguir a noite do dia ou o quente do frio); o que se entende é que a figura da oposição que se encontra em todos os juízos analíticos não é confiável, precisamente porque ela permite, no interior da linguagem à qual pertence enquanto figura, substituições que não ocorrem da mesma forma no mundo empírico. Quando passamos de uma oposição empírica como aquela entre a noite e o dia para uma oposição categórica como entre a verdade e a falsidade, as apostas epistemológicas aumentam consideravelmente, pois, no plano de conceitos, o princípio da exclusão opera decisivamente. A função crítica da desconstrução não é de tornar nebulosas as distinções, mas de identificar o poder da figuração lingüística em transformar diferenças em oposições, analogias, contigüidades, reversões, encruzilhadas e qualquer outra coisa que seja da ordem das relações que articulam o campo textual de tropos e de discurso. (tradução nossa) 
Adequadamente, na teoria derridiana, a desconstrução não tem a pretensão de ser algo totalmente inovador na história do pensamento humano, pelo contrário, ela parte precisamente do reconhecimento do fato de que o sonho de começar tudo de novo foi o que sempre moveu os filósofos, geração após geração. Na desconstrução, a interpretação não é fechada e acredita-se que o signo não possui um significado imediato; não é uma coisa presente e sim um processo de presença e ausência que não pode ser considerado como uma verdade homogênea. Assim, o signo, o significado, o próprio indivíduo, a linguagem, a ideia total de estabilidade humana passam a ser fictícios.

Esse conceito pode ser encontrado no pensamento de Eco (1991a), via colocações que em muito se aproximam do termo "desconstrução", visto que, na sua concepção, a obra de arte não comporta apenas uma interpretação. De acordo com o semioticista italiano, as motivações para a poética da obra aberta podem ser encontradas nas teorias da relatividade, na física quântica, na fenomenologia etc., as quais descentralizam e ampliam os horizontes imagináveis para a concepção da realidade, de pluralidade de sentidos do mundo e do seu caráter multifacetado.

A seguir, Eco (1991a, p. 41) fala sobre uma possível categoria de obras que são determinadas quanto à forma, mas indeterminadas quanto ao conteúdo, pois sua estrutura é composta por signos que evocam os mais diversos sentidos interpretativos:

A poética da obra "aberta" tende, como diz Pousser, a promover no intérprete "atos de liberdade" consciente, pô-lo como centro ativo de uma rede de relações inesgotáveis, entre as quais ele instaura sua própria forma, sem ser determinado por uma necessidade que the prescreva o modo definitivo de organização da obra fruída; mas [...] poder-se-ia objetar que qualquer obra de arte, embora não se entregue inteiramente inacabada, exige uma resposta livre e inventiva, mesmo porque não poderá ser realmente compreendida se o intérprete não a reinventar num ato de congenialidade com o autor. 
Outro teórico que tem investigado esse conceito, Jauss (1979, p. 81), fala sobre as três categorias da experiência estética:

As três categorias básicas da experiência estética, poiesis, aisthesis e katharsis não devem ser vistas numa hierarquia de camadas, mas sim como uma relação de funções autônomas: não se subordinam umas às outras, mas podem estabelecer relações de seqüência. Em face de sua própria obra, o criador pode assumir o papel de observador ou de leitor; sentirá então a mudança de sua atitude, ao passar da poiesis para a aisthesis, diante da contradição de não poder, ao mesmo tempo, produzir e receber, escrever e ler. Quando o leitor contemporâneo ou as gerações posteriores receberem o texto, revelar-se-á o hiato quanto à poiesis, pois o autor não pode subordinar a recepção ao propósito com que compusera a obra: a obra realizada desdobra, na aisthesis e na interpretação sucessivas, uma multiplicidade de significados que, de muito, ultrapassa o horizonte de sua origem.

Derrida (1976, p. 125), observa que a ideia de diferença também traz consigo a ideia de vestígio, o que o signo deixa, isto é, a parte ausente da presença do signo. Para Derrida, o vestígio não existe em si porque é modesto "(i)n apresentando, torna-se eliminado". Mas todos o assistirão como presente no pensamento ocidental, pois, ainda que necessariamente contenha vestígios de outro signo (ausente), ele não está nem totalmente presente, nem totalmente ausente. Essa ocorrência, rompimento de qualquer noção de coerência única, passa a apontar em outras direções, tendo em vista que uma das características do conceito de desconstrução nas artes visuais é liberar o artista de quaisquer conceitos tradicionais.

\section{Isto não é um cachimbo e Canyon}

O estudo dos conceitos do ponto de vista etimológico amplia nossa concepção, possibilitando fazer conexões e associações epistemológicas com as mais diversas teorias da arte contemporânea. Através desse conhe- 
cimento, podemos ampliar reflexões, buscando termos apropriados que dialogam entre si ou que propiciam um acesso à semiose, onde os signos da arte crescem e geram conhecimento.

A obra de Michel Foucault, mais especificamente The order of things, (1969), publicada em francês, em 1966, como Les mots et les choses (As palavras e as coisas, na versão para o português), oferece uma abordagem sobre a arqueologia das ciências humanas. O interesse de Foucault (1969) sempre esteve voltado para a investigação, na história da cultura ocidental, das mudanças nas noções de representação, uma distinção entre a representação e o mundo, por meio de vários ângulos, um tipo de escavação arqueológica. Por arqueologia, aqui entendida como diferenças entre história intelectual e fenomenologia, e na qual tudo o que percebemos somente pode ser reconhecido através da rede de relações sígnicas. Esse autor vai se interessar pelos modos de representação presentes na linguagem e nas artes, como a pintura do artista espanhol Diego Velázquez, Las meninas, e Isto não é um cachimbo, de René Magritte. Suas considerações levantam importantes reflexões sobre a questão do espaço, do tempo, do desaparecimento da fundação da semelhança, do jogo semiótico e estético, do desvelamento do invisível na obra etc.

Para Foucault (1969), a ordenação por meio dos signos constitui todos os saberes empíricos como saberes da identidade e da diferença, e partindo desse pressuposto, escolhemos dois artistas de períodos diferentes na história da arte, René Magritte e Robert Rauschenberg, que permitem abordagens conceituais à luz dos conceitos de representação e desconstrução, tendo como corpus principal a pintura Isto não é um cachimbo (1928) e o combine Canyon (1959), respectivamente, as quais provocam desestabilização, o distúrbio causado sobre a ilusão de realidade que uma representação realista pretende endereçar.

Independentemente da intenção do artista, assunto já abordado em capítulos anteriores, a obra nos aparece sem acompanhamento de um manual de instrução. Diversamente de objetos que possuem função aparelhos, remédios etc. - , uma obra é sempre primeiramente um ícone. Nas suas declarações sobre essa obra, Magritte afirma não significar nada, 
apenas o mistério, e como o mistério nada significa, a obra não pode ter qualquer significado. Ao mesmo tempo, Magritte parecia desfrutar da polêmica causada por essa pintura, uma certa afinidade com o jogo semântico e ao mesmo tempo estético, que coloca o real em conflito com a sua representação. Comumente somos seduzidos por um impulso em acreditar no poder da palavra, assim como no poder da imagem, e raramente tomamos consciência que o objeto real não pode ser apreendido por meio de quaisquer tipos de representação.

À luz das teorias de Foucault (1969), Magritte retrata um tipo de cachimbo platônico, em virtude de seu tamanho desproporcional e seu deslocamento no espaço do quadro, fazendo com que o cachimbo seja um objeto utópico feito para parecer uma miragem, enquanto a descrição na lousa goza de uma maior dignidade ontológica. Assim como em outras teorias contemporâneas, refletir à luz desse conceito, é sempre um desafio complexo, sobretudo quando se trata de uma obra como essa em que ora nos debruçamos, porque, enquanto a pintura continua sendo uma representação por excelência, seu objeto dinâmico é um cachimbo. Além de pintar um cachimbo da maneira mais real possível, Magritte insere na própria pintura, ou melhor, no seu quadro, uma frase (título da pintura: Isto não é um cachimbo) que nega o objeto representado.

Logo a um primeiro olhar, trata-se de uma afirmação e em seguida de sua negação. Não obstante, sendo uma representação de semelhança com o seu objeto dinâmico, o pintor tem razão em negar a sua existência, visto que jamais poderemos pegar esse objeto, apalpá-lo, sentir o cheiro do tabaco, ou seja, sendo a função do cachimbo um objeto feito para fumar tabaco, jamais poderemos fumar tabaco através de uma pintura. No entanto, Ceci n'est pas une pipe propõe uma ponderação sobre conceitos fundamentais, como semelhança e representação, a relação entre texto e imagem, o signo verbal e sua representação visual, todos estes, proposições semióticas sobre obras do modernismo.

quadro mostra um cachimbo que foge do gênero predominante da época, o Abstracionismo; opostamente, é uma imagem realista de um cachimbo que em muito se aproxima de uma reprodução gráfica de 
propaganda, pela composição dos elementos visuais na tela. Melhor ainda, em muito se assemelha a outras pinturas da década de 1920, conhecida como os "anos dourados da propaganda" americana.

Ao elegermos Canyon (1959), uma das mais renomadas obras do artista americano Robert Rauschenberg, para dialogar com a pintura de Magritte, acima descrita, levamos em conta alguns itens que podem ser observados a partir dessas duas obras. Ao reinventar a colagem e a assemblage, Rauschenberg fez um complexo jogo entre os objetos que representam o cotidiano e a história ocidental, em uma organização visual refinada que demonstra o quanto esse artista domina o vocabulário técnico-formal e conceitual da arte. O que sobressai é um tipo de celebração e reverência à realidade precária, o cotidiano como arte. Muitos dos elementos incluídos no trabalho fazem referência à cultura popular americana, alguns de seus principais ícones, como uma imagem da estátua da liberdade, uma águia empalhada, objetos descartados do cotidiano, pedaços de tecido, papelão, papel, fotografias, metal, tinta etc. Tanto a estátua da liberdade como a águia são símbolos relacionados a "uma América livre". Contrariando essa ideia, segundo alguns críticos, a águia na obra de Rauschenberg, empalhada, não é patriota, mas uma ave abatida que não carrega na sua imagem a força do pássaro águia.

Danto (1998) informa que Robert Rauschenberg, bem como outros artistas desse período, a exemplo de Jasper Johns, estava com o interesse voltado para o arbítrio transformador transmitido pela cultura de massa e da publicidade, uma herança da contracultura. Assim, a obra desses pintores surgiu em reação à pintura enquanto técnica, à matéria utilizada no modernismo, à tinta sobre a superfície, ao ato de pintar e nada mais.

Opostamente a esse tipo de matéria, Rauschenberg apresenta o que Danto (1998) denomina de esthetic taxidermy; a maneira como a obra deveria ser efetivamente, como a maneira dos acontecimentos políticos dessa época. Porém, não podemos considerar o cachimbo e a águia como signos semelhantes, visto que a águia é real, enquanto o cachimbo, não. Mesmo estando agora empalhada, podemos pegá-la, sentir a textura de suas penas, suas asas, e mesmo que não possa mais voar, arriscamos afirmar 
que essa ave já existiu em algum momento, teve vida e, provavelmente, voou! Assim como todas as aves o fazem; possivelmente também foi altiva, como são as águias; alimentou-se; quiçá, procriou...

As duas coisas - águia e cachimbo - em muito se assemelham: enquanto transfiguração de espaço, deslocamento de objetos de uma função para a arte; enquanto apropriação de imagens e de objeto etc. Por mais incoerente que a obra de Magritte pareça, ela ainda está configurada no espaço arte, numa tela, pintura, enquanto a águia se apresenta tal como ela é: à guisa de interpretação.

Deste modo, da mesma forma que a águia na obra de Rauschenberg passa a ser um signo visual, o objeto mostrado não é um cachimbo. Esse tipo de obra provoca complexidade de apreensão devido ao processo de destruição das noções inerentes à arte tradicional: representação e lógica.

Michel Foucault (1969), empenhado em escavar as noções de representação na história de cultura ocidental, assegura que nada possibilita um conhecimento e entendimento absoluto, sobretudo no que diz respeito à arte, onde não existem convenções de verdade; todo conhecimento deve transcender sua fonte de representação, verbal ou pictórica. Portanto, apenas nos cabe continuar sempre nesse processo desconstrutivo, sem querer chegar a um consenso final.

Quanto ao cachimbo e à águia, pesa a instabilidade de um signo arte, que nos encanta pelo seu jogo inteligente e enigmático. $E$ o que ambas as obras, Canyon e Isto não é um cachimbo propõem é um jogo semiótico e estético com o observador, assim como o signo semiótico.

\section{Isto é real ou é arte?}

As indicações bibliográficas que nos serviram de apoio na construção de premissas epistemológicas sobre essa interrogação, recorrente a partir dos anos 1960, estão presentes nas obras de alguns teóricos, a exemplo de Christopher Benfey (1997), Michel Newman (1991) e, sobretudo, Arthur C. Danto (1998).

No ensaio crítico de Christopher Benfey, Objects of beauty: still lifes and natures mortes (1997), sobre a exposição "Objects of Desire: The Modern 
Still Life", realizada no New York Museum Of Modern Art, em Nova lorque, em 1997, natureza morta é um gênero de pintura que representa objetos familiares inanimados, e, como o nome sugere, um tipo de gênero paradoxal. Em francês, "natureza morta" significa morte da natureza, e teve sua origem, supostamente, a partir de uma competição legendária de pintura, ocorrida por volta dos anos 400 a.C. Reza a lenda que Zêuxis, pintor grego, havia pintado uvas tão realistas que os pássaros foram bicá-las. Por sua vez, seu rival, Parrhasios, secretamente pintou uma cortina, e ao ver o quadro do seu concorrente, Zêuxis diz: "bem, agora nos mostre o que você pintou atrás disto?" E assim Parrhasios venceu Zêuxis. (NEWMAN, 1991, p. 112, tradução nossa) Esse gênero de pintura, que teve seu auge na Holanda, durante o século XVII, passou a representar frutas e tecidos que enganavam os olhos (trompe l'oeil) do espectador, fazendo com que ele sentisse vontade de cheirá-los e senti-los.

Para Benfey (1997), as naturezas mortas também possuem um lado obscuro, pois elas advertem sobre a brevidade dos prazeres terrenos, ao apresentarem imagens de alimento e objetos pessoais pintados pelos egípcios antigos em seus túmulos (pinturas feitas para acompanhar o morto em sua última viagem). Por outro lado, tornou-se uma rica tradição europeia que celebrava esses pequenos lembretes de mortalidade, como crânios flutuando entre velas, maçãs, peras e limões descascados etc.

Na exposição "Objetos de Desejo”, pinturas de grandes mestres, como Cézanne, foram apresentadas juntamente a obras de Man Ray, Marcel Duchamp, Andy Warhol, que não dialogavam entre si, mas juntas levantaram justamente essa questão: Is it real or is it art? [Isto é real ou é arte?]. Um de seus objetivos era mostrar como os mesmos objetos - garrafas de vinho e frutas, cachimbos e estojos de barbear -, no repertório limitado da natureza morta, possuem diferentes significados, tanto no âmbito público como no âmbito privado, em diferentes espaços de tempo, ou seja, cada civilização possui um determinado tipo de espaço para suas representações.

Danto (1987) foi motivado a se dedicar ao estudo da Pop Art, pelo equívoco provocado nele pela obra do americano Andy Warhol, Brillo Boxes. Dessemelhantes da simples caixa de sabão que leva esse nome, 
pelo simples fato de estarem expostas em lugares com funções diferentes, as caixas de Warhol ocupam espaços institucionalizados da arte, enquanto as caixas de sabão vão estar sempre em prateleiras, à venda. Esse fato foi assunto de um dos primeiros ensaios de Danto, publicado no Journal of Philosophy, em 1964, e duas décadas mais tarde, em Art and its significance: an anthology of aesthetic theory (ROSS, 1987).

A filosofia de Danto está concentrada no permanente discurso do "real" e na transposição do lugar comum para a arte, assim como na relação existente entre arte e teoria da arte, como possibilidade de determinar se alguma coisa pode ser considerada arte. Um dos exemplos a que ele recorre é também a pintura de Zêuxis, um tipo de arte que provoca equívocos interpretativos. Porém, esse ato de confundir o que é real com o próprio real, não reside no erro, mas em definir o que é arte e o que é objeto real. Ver algo como arte requer algo que o olho não pode menosprezar; a atmosfera de uma teoria da arte, um conhecimento da história da arte: o mundo da arte. Além de Zêuxis, Danto (2001a, p. 478), elucida essa questão:

Antes de ter estudado Zen por trinta anos, eu via as montanhas como montanhas, e água como água. Depois de ter alcançado um conhecimento mais íntimo, cheguei a um certo ponto em que passei a ver que montanhas não eram apenas montanhas, bem como água apenas água. Agora, que eu consegui perceber a essência das coisas, estou tranqüilo. Pois consigo ver as montanhas de novo como montanhas, e a água, mais uma vez, como água. (tradução nossa)

Segundo Danto (2001a, p. 470), é de competência do observador fazer a distinção entre o que é real e o que é arte, a partir de como ele pode ver e apreender as coisas, caracterizando como o termo "representação" era entendido na Antiguidade:

Tanto Hamlet como Sócrates falaram sobre a arte como espelhamento da Natureza. Entre desacordos, essa contestação possui bases factuais. Se por um lado Sócrates via espelhos como reflexos 
do que nós poderíamos perceber, já Hamlet reconheceu uma característica marcante nas superfícies espelhadas. Sócrates, ao detectar que os espelhos não mostravam nada a mais do que podíamos alcançar, a arte como espelho permite duplicações das aparências das coisas, não havendo, portanto, nenhum benefício cognitivo. Há de se considerar que, na época de Sócrates, a arte tinha essa função, o que não ocorre na nossa atualidade. (tradução nossa)

Nesse período, Sócrates e depois os artistas estavam engajados no processo de imitação, e a insuficiência da teoria não foi identificada até a invenção da fotografia. Uma vez rejeitada, a mimesis foi rapidamente descartada, mesmo a mais necessária delas; e, desde então, sobretudo depois de Kandinsky, características miméticas têm sido relegadas a uma periferia de reconhecimento crítico.

\section{Por que alguma coisa é arte enquanto outra não é?}

Segundo Danto (1986, p. 74), Marcel Duchamp foi o primeiro artista a levantar a seguinte questão: "Por que alguma coisa é arte enquanto outra igualmente a ela não é?" (tradução nossa) Como o próprio Danto afirma, a arte contemporânea surge de uma aproximação com o cotidiano, com a estética do cotidiano - a estética da marca -, o que une arte e vida. (tradução nossa)

Para esse filósofo, além de Duchamp, Andy Warhol mostra que a arte deixa de ser puramente ocularcêntrica para ser entendida através do conceito, ou seja, uma arte conceitual que situa ou incita o observador a refletir sobre o que é e o que não é arte.

Danto aborda a intenção da arte contemporânea em distinguir objetos, situações e acontecimentos, denotados como arte, e suas contrapartidas na realidade. Para ele, a arte é um território cultural livre, que permite interpretações distintas e diferenciadas, tanto para o criador quanto para o espectador. Ao definir a arte como algo que prende nossa atenção e que não sofre a interferência de pensamentos alheios, esse autor diz que a arte tem a ver com a forma de engajamento e de compromisso do trabalho com algum aspecto do mundo. Danto (1981, p. 12) retoma antigas 
discussões platônicas, como imitação e realidade, a relação entre a arte e meras coisas reais, expondo:

Quem escolheria a aparência de uma coisa sobre a coisa em si mesma; quem contentar-se-ia com um quadro de alguém se ele pode ter a própria pessoa em carne e osso. [...] $\bigcirc$ virtual e o táctil brincam com a nossa atenção. Quem não se impressionaria com a força contínua da imaginação perante o vazio: o poder de reproduzir e inventar. Ambos têm o potencial de liberdade e coação. (tradução nossa)

Um dos principais impulsos nas artes contemporâneas passa, então, a ser a transferência de significado provocada pelo deslocamento constante do signo, do espaço, da matéria, da imagem e dos objetos da vida cotidiana, para o mundo da arte, celebrando o rompimento com a autoridade e a homogeneidade das técnicas e materiais tradicionais, e, consequentemente, a pintura, a escultura, o desenho e a fotografia passam a determinar suas próprias autonomias.

O conceito de representação passa a ser visto de um modo mais amplo, ou seja, imagens de arte foram usadas para interrogar sobre a sua própria definição, imagens como imagens, reassertation of representationality, a natureza de imagens, a apropriação de imagens já existentes, cópia de cópias. A descentralização de normas e regras pertinentes à pintura e à escultura (consideradas como técnicas tradicionais) permitiu que seu curso tomasse diversos rumos, não havendo uma substituição dessas técnicas por outras correspondentes, mas uma democracia, se assim podemos denominar, no sentido de misturar elementos, materiais, objetos e imagens, indeterminadamente. E nesse percurso algumas iniciaram um processo de hibridização entre escultura e fotografia, pintura e fotografia etc., sem uma determinada terminologia que pudesse acompanhar pari passu esse procedimento.

\section{Depois do fim da Arte: Arthur C. Danto}

Danto (1997a) introduz um olhar retroativo aos seus ensaios, bem como à arte do final do século $X X$, admitindo que o tão polêmico assunto sobre o 
fim da arte, proposto por ele junto ao historiador alemão Hans Belting, foi uma tomada de consciência do momento histórico pelo qual a arte estava passando, com todas as mudanças ocorridas na década de 1960.

Inspirado no livro de Hans Belting, Likeness and presence: a history of the image before the era of art (1994), que traça a história de imagens de devoção no cristianismo ocidental, do período romano até aproximadamente 1400 d.C, para definir outro viés de reflexão, Danto (1997a) faz uma revisão do início da arte, a partir das considerações desse autor, sobre os objetos que não foram produzidos com a intenção de ser arte, visto que o conceito de arte até então não fazia parte do inconsciente coletivo.

A teoria de Belting (1994) sobre objetos e artefatos - feitos fora de uma real intenção artística - deve ser considerada a partir de sua origem, ou seja, da mentalidade e intenção da comunidade da qual eles faziam parte. Esse assunto tem provocado controvérsias entre muitos teóricos, pois, se por um lado existe uma teoria que defende que tudo que é feito pela mão do homem é arte, por outro lado, pesquisadores apresentam, adequadamente, pressupostos que devem ser analisados à luz de outras áreas, como a antropologia, a etnologia, a história etc.

O pensamento de imagens fora de um contexto cultural provoca ambiguidades irreparáveis para a pesquisa da arte, visto que nenhuma imagem era feita sem uma determinada função. Todas elas tinham uma função em sua sociedade de origem, função esta bastante diferenciada do que mais tarde veio a ser conhecido sob um conceito estético. Anteriormente, objetos sequer foram pensados como arte no sentido elementar, nem sob a nomenclatura artística. $O$ que essas imagens se propunham era um tipo de representação funcional, seja da ordem do cotidiano, seja da ordem do espiritual. As imagens, no contexto abordado por Danto (1997a), estavam ligadas a essa última ordem - religiosa -, e a relação entre as práticas artísticas antes e depois da era da arte é imensamente descontínua, pois o conceito de arte não estava presente nem na intenção nem na ideia dessas imagens de devoção, como veio a acontecer muito mais tarde, no Renascimento. 
Se por um lado essa era não começou bruscamente em 1400, da mesma forma, ela não desapareceu antes dos meados de 1980, e os textos de Arthur Danto e Hans Belting foram publicados na década de 1960. Enquanto Belting (1994) fala sobre a arte antes do começo da arte, já a proposta de Danto (1997a) parte da ideia de se pensar a arte depois da arte.

Outside the pale of history (fora do limite da história) é uma expressão, empregada por Hegel, na obra Critique of pure reason que Danto (1997a) utiliza para distinguir do termo "pureza", que ele define como maturidade, ao descrever algumas práticas, como o Surrealismo. A palavra pale (parte do título de seu livro) é traduzida como um tipo de parede, algo que isola, exclui e afasta. Se, por um lado, Greenberg (1960) considera o Surrealismo uma regressão na arte moderna, ou seja, uma reafirmação de valores da infância da arte, repleta de monstros e ameaças assustadoras, Danto (1997a), por sua vez, vai considerar esse movimento como uma incorporação da impureza, uma arte preocupada com os sonhos, o inconsciente, o erotismo etc., ou, também como Foster (1997), que o denomina: the uncanny (o esquisito).

O Surrealismo fora para Greenberg (1960) o mesmo que a pintura acadêmica foi para o outside the pale of history. Pós-histórico e pluralismo são considerados como o período e a tendência que surgem depois da “morte da arte", quando já não existe hierarquia em qualquer tipo de prática, um momento de informação da desordem, no sentido de liberdade. Desse modo, a arte conceitual demonstrou que não seria mais necessária a presença de um objeto palpável. O que significa que, até onde as aparências forem consideradas, qualquer coisa pode ser arte. Para procurar descobrir o que é arte, é necessário retornar à experiência dos sentidos para o pensamento, isto é, se voltar para a filosofia. A arte conceitual, portanto, acontece em um espaço onde o objeto arte não está necessariamente presente, e sua apreensão tem que se dar num espaço mental, intelectual. Trata-se, portanto, de signos que dependem de uma experiência colateral para serem apreendidos.

Porém, o ponto crítico de Danto (1997a) e Belting (1994), ao falarem sobre o fim da arte, foi uma reivindicação sobre como um complexo de 
práticas tinha dado passagem a outras, ainda que a forma desse novo complexo de práticas não fosse ainda evidente. Danto (1997a) confirma que não houve uma intenção da sua parte, nem da parte de Belting (1994), em declarar a morte da arte, mas, uma vez assim entendido, de um certo modo, ele aceita o desafio e interpreta o fato, apresentando uma justificativa encontrada em certos gêneros de histórias alemãs, como o bildungsroman, que diz que a vida realmente começa quando a história chega ao seu final, do mesmo modo que nas histórias em que todos os casais se encontram e vivem felizes para sempre. Portanto, se a pintura na década de 1950 só havia pensado numa possibilidade, a abstração materialista, porque estava sobre os materiais da pintura e nada mais, já o pluralismo objetivo, como Danto (1998, p. 123) o entende, vai apontar para o fato de que não há nenhuma possibilidade histórica mais verdadeira do que qualquer outra.

Em 1990, a abstração pós-histórica era mais uma dentre um número de possibilidades estéticas, um quarto de século depois que uma resposta filosófica à pergunta da arte tornou-se disponível, os artistas estão liberados para fazer algo ou tudo. Uma recordação nítida de um artista alemão, Hermann Albert, que, de acordo com Danto (1998, p. 125), foi com ele que o momento pós-histórico surgiu, assim é descrita:

No verão de 1972 estava em Florença temporariamente, e num fim de semana fiz uma viagem às montanhas com alguns colegas. Saímos do carro e na campina toscana, com árvores de cipreste, os bosques de azeitona e as casas antigas, havia harmonia. $\mathrm{O}$ sol estava a se pôr, mas seus raios de luz ainda continuavam iluminando a campina obliquamente; as sombras ficavam cada vez mais longas, e podia-se perceber a aproximação do anoitecer embora fosse realmente ainda dia. [...] Ficamos aí, com a própria consciência, olhando este espetáculo dramático, e repentinamente um de nós disse: "É uma pena você não poder mais pintar hoje em dia". Isso tinha sido uma palavra chave que eu tinha ouvido desde quando comecei a tentar ser pintor. E então respondi: "Por que não? Você 
pode fazer tudo". Depois disso compreendi que o que inicialmente tinha sido um pedaço de provocação era realmente verdadeiro. Por que eu não posso pintar um ocaso? (tradução nossa)

Danto sublinha a data: 1972, ao também sublinhar o maravilhoso desafio de Albert: “Você pode fazer tudo". (1998, p. 125, tradução nossa)

Os anos 1970, para Danto (1998), constituem um período fascinante, marcado pelo fato de não haver apenas um único movimento, mas uma década onde tudo aconteceu. Pareceu, a esses que a viveram, uma idade de ouro. E, de acordo com Danto (1998, p. 125), o que lhe deu esse caráter foi essa estrutura pluralista objetiva da pós-história: não era mais necessário perseguir a verdade material da arte. Foi uma época de uma liberdade imensa, e desde que a estrutura de galeria não decidia o que era "realmente" arte, os artistas não tiveram nenhuma expectativa especial de qualquer jeito de fama nem fortuna.

Os artistas acreditavam que podiam viver apenas com pouco dinheiro, e fazer o que eles queriam fazer para um círculo pequeno de pessoas que comungavam da mesma opinião. Outro tipo de prática visual que começou a ascender nesse período foi a arte feminista. As exposições marcantes desse período, como "Decade Show" (1990), no New Museum, no Studio Museum, no Harlem, e no Museum of Contemporary Hispanic Art, marginalizaram a pintura de cavalete. As razões, certamente, eram diferentes das que prevaleceram em Berlim, em 1920, em Moscou, em 1921, ou no México, em 1942. Então o lema "Você pode fazer tudo!" - frequentemente e politicamente, foi colocado em prática.

A arte contemporânea manifesta uma consciência da história da arte, não obstante não a leve mais adiante, pois a relativa perda de fé, mais recentemente, nas grandes narrativas, requer outras análises. $O$ que está agora registrado em nossa consciência é a sensibilidade histórica do presente, e a arte contemporânea não se opõe à arte do passado; em nenhum sentido, o passado é algo a ser combatido através de lutas. Para a arte contemporânea, o passado está disponível aos artistas que parecem cuidar 
bem dele, esclarece Danto (1998), mas o que não está mais disponível aos artistas é o espírito no qual essa arte foi feita.

\section{Apropriação e outros conceitos}

Duve (1998, p. 13), assinala que o ready-made de Duchamp, "urinol", rebatizado com o nome de fountain, encontra-se veneradamente guardado no museu sob o nome "arte", como parte do patrimônio cultural. Nesse contexto, o ready-made manifesta o poder mágico da palavra arte, uma vez que ele pode, ao mesmo tempo, abarcar todas as teorias da arte ou desqualificá-las totalmente. Sendo um objeto retirado de sua função utilitária, em nada se assemelha às coisas que carregam o nome arte, exceto quando as coisas como ele, o urinol, são chamados de arte. Neste sentido, nas artes contemporâneas visuais, as coisas podem ter ao mesmo tempo o nome de arte ou serem assim denominadas. Estando colocado no museu, de acordo com Duve, a essa altura contempla-se um paradigma como se fosse uma "Afrodite de mármore". (tradução nossa)

Em 1991, Sherrie Levine constrói uma série de seis peças de bronze apropriadas do "urinol" de Duchamp. Nessa obra, alguns aspectos se destacam. Primeiro, trata-se de uma reapropriação, ou melhor, apropriação de algo que já fora apropriado anteriormente. Nesse momento, o urinol foi elevado à condição de arte não mais apenas pela transposição de um espaço (isto Duchamp já havia feito), mas por ser um bronze, material considerado como o selo de garantia, nos moldes tradicionais, de uma verdadeira obra de arte.

Para Sandler (1996, p. 8), o conceito de vanguarda desapareceu com o seu principal objetivo, visto que a maioria do público, cada vez maior, não respondeu negativamente frente à arte que passou a surgir, seja de uma forma não permissiva, seja de uma forma passiva. Muitos artistas que deixaram de acreditar em visões futuristas começaram a reciclar imagens e formas do passado e dos meios de comunicação. Assim, a apropriação foi 
considerada como um dos primeiros índices da arte pós-moderna. Havia também uma negação concomitante à originalidade, à experimentação, à inovação e à invenção, apreciada pelos modernistas. Contudo, o que estava sendo apropriado devia ser provocativo, mas a provocação não era mais equiparada à novidade, como havia sido quando a ideia de vanguarda ainda possuía crédito. (tradução nossa)

Não obstante o termo "apropriação" ter se tornado um dos principais conceitos das artes visuais contemporâneas, ou estratégias, a partir das práticas artísticas que surgiram nos anos 1960, é certo que não se pode precisar com segurança qual a extensão da sua aplicação, já que seu significado é abrangente: designa o ato ou efeito de tomar para si; apoderar-se; tomar posse de algo que não lhe pertence e torná-lo próprio etc. Além da sua presença nas artes visuais, a apropriação possui também um papel relevante na literatura, através da linguagem, que, segundo Roland Barthes (1991), encontra-se no processo de enunciação e do discurso. Assim sendo, é uma atividade que coloca o homem em relação com o mundo, seja através do discurso, seja através de seu relacionamento com a sua própria existência, por meio da experiência, da mediação, do contato com o outro (não apenas uma mente humana, mas com tudo o que se exterioriza e se apresenta). Nesta relação, o homem passa a ter um novo conhecimento através daquilo que ele apropriou da experiência: emoções, sentimentos, sensações etc.

Alguns índices do conceito de apropriação podem ser identificados em obras de artistas das vanguardas modernistas, além de Marcel Duchamp - um dos artistas mais celebrados nesse contexto -, como Pablo Picasso, Georges Braque, Kurt Schwitters, Méret Oppenheim, o grupo neoDada (1950) - Robert Rauschenberg, Jasper Johns, John Cage, Merce Cunningham -, artistas do Fluxus, artistas da Pop Art, John Baldessari (ready-made da imagem - apropriação de imagens), dentre tantos outros.

$\mathrm{Na}$ esteira do conceito de apropriação, outros termos têm sido aplicados às artes visuais, não obstante fazerem parte de outras áreas do conhecimento humano, como rizoma, e os que são discutidos na sequência.

Etimologicamente, o termo "rizoma" possui significado em botânica, referindo-se a uma determinada característica presente em algumas 
plantas, a partir da constituição de seu caule. Diferentemente da raiz, que parte do tronco e se espalha, tendo início e fim, mesmo que em longas ramificações, o rizoma se desenvolve de outras formas, tanto em sentido aéreo quanto horizontal. Como conceito filosófico, está mais presente na obra dos franceses Deleuze e Guattari (1997), rhizome, muito embora seja também usado por Carl Jung, tendo se expandido para outras áreas, como a semiótica.

Assim como o rizoma, outros conceitos foram ampliados em seu significado original, a exemplo de desterritorialização (processos de deslocamento, devir etc.); desenraizamento; transitoriedade; desdobramento, dentre outros. Eles aludem o rizoma àquilo que permite múltiplos, isto é, uma entrada não-hierárquica e pontos de saída nos dados de representação e interpretação. Deleuze e Guattari (1997) opuseram-se a uma concepção arborescente do conhecimento, ou seja, a uma concepção que se define como um tipo de árvore. O rizoma, dada a sua natureza múltipla e não-hierárquica, trabalha com conexões horizontais e trans-espécie -, enquanto o modelo arborescente funciona apenas com conexões verticais, lineares e hierárquicas. Ao explorar outras vias, como a arte e o artista, relações identitárias, semiose, signos híbridos, podemos recorrer à ideia de dobra, seja uma desdobra física, técnica, matérica e espacial das artes, seja seu contexto cultural. Por esse viés, os signos culturais a nós transmitidos implicam fragmentos, dobras, a forma como experienciamos nosso espaço de vivência por meio dos signos visuais, nosso próprio corpo, a linguagem, sentimentos, emoções, sensações. Diferentemente do pensamento dualista, dos opostos, esses conceitos permitem desdobramentos; perceber as dobras existentes em nós, no outro, e nas relações fenomenológicas.

De acordo com Sandler (1996, p. 6), certamente nos anos 1980, os trabalhos de artistas considerados impuros, que misturavam meios artísticos, abraçando a diversidade e, ocasionalmente, aspirando ser enciclopédicos, eram obras que buscaram sua inspiração no imaginário vernáculo, na mídia e em comodidades. Impuro, nesse contexto, é um termo oposto ao termo "puro", "pureza", uma das características da arte formalista, quando as técnicas, sobretudo a pintura, deveriam estar voltadas para o uso de 
seus materiais e suportes lógicos. Nesse sentido, "impureza" é uma palavra utilizada para as novas linguagens visuais, que passaram a misturar técnicas, em um processo que veio a ser denominado de hibridização. Além de ser um termo que foi aplicado às artes visuais, hibridização se encontra também em estudos de comunicação, semiótica e cultura. Santaella e Nöth (2004, p. 9) descrevem a década dos anos 1970 como sendo o boom da semiótica e dos estudos comunicacionais. Para esses autores:

De fato, frente à multiplicidade das práticas comunicacionais, a sociologia da cultura, em que os estudos culturais se abrigam, é sensível à incorporação da semiótica. [...] Os processos de hibridização não são simplesmente meios, mas, antes de tudo, trata-se de hibridizações simbólicas, cuja heterogeneidade, nos centros urbanos em crescimento e nos ambientes do ciberespaço, cresce exponencialmente. [...] Misturas ou hibridizações são aquelas que se processam através das intervenções propositadas do artista no ambiente que o circunda, especialmente o das galerias, museus e mesmo o ambiente urbano. Tais intervenções são frutos de um gesto imaginário-cultural de apropriação e transfiguração de todos os meios que a galáxia semiosférica coloca à disposição do artista.

Esses estudos são também encontrados na obra de Canclini (2006), que analisa a cultura nos países da América Latina, onde as tradições culturais coexistem com uma modernidade que ele considera ainda tardia nesse continente. Canclini propõe maiores reflexões sobre o fenômeno da hibridação cultural nos países latino-americanos, procurando compreender o intenso diálogo entre a cultura erudita, a popular e a de massas, e sua inserção no cenário mundial. O processo de hibridização é inerente ao homem, pois as culturas sempre tomaram emprestados de outras sociedades elementos específicos que as caracterizam. No mundo contemporâneo, esse processo teve um crescimento veloz, devido à revolução dos meios de comunicação e de transportes, que permitem que o homem entre em contato com o mundo todo. 
Já a marcante característica da desmaterialização nas artes visuais está em tudo aquilo que se expande fora dos limites das técnicas tradicionais, seja através dos materiais, do suporte, seja através da expansão do espaço inerente à arte que se configurava apenas por meio da pintura e da escultura. Ainda recorrendo às informações bibliográficas de Sandler (1996, p. 11), durante o pós-modernismo, as técnicas tradicionais, ao se afastarem de suas nascentes e se espalharem por espaços, antes ainda não percorridos, deram origem a uma diversidade incomparável, até então, de práticas visuais, como Process Art (Antiforma), Earth Art etc. Todas essas situações sinalizavam para obras efêmeras, atualizadas em espaços e tempo reais, que confrontaram o mundo da arte tradicional, que via a obra artística como um objeto estável. Materiais perecíveis sugeriam a vulnerabilidade da condição humana, trazendo à mente a insignificância, fragilidade e impermanência da humanidade. Os depoimentos do artista Sol LeWitt (1967, p. 11) caracterizam a arte conceitual que nos faz refletir sobre obras consideradas desmaterializadas, as quais contestavam o conceito tradicional de autoria, ao tempo em que cortejavam a efemeridade ou imaterialidade. (tradução nossa) Considerado um termo abrangente, a arte conceitual foi reconhecida como um dos últimos movimentos do modernismo, que dá início a uma arte mais voltada para a questão do conceito, abordando um campo de diferença, um jogo de posições estratégicas formuladas ao redor da exploração artística da linguagem, e a interseção consequente deste empreendimento com uma crítica de caráter sociopolítico. Lawrence Weiner (1996), artista conceitual, no ensaio Reconsidering the object of art: 1965-1975, considera o objeto-arte como algo obsoleto, o que veio a ser discutido, a partir de predicados de especificação espaçotemporais, como indeterminação da arte. (tradução nossa) Nesse período de surgimento de várias manifestações artísticas, que extrapolaram as características da pintura e da escultura, as quatro considerações apresentadas a seguir, por Duve (1998, p. 413-414) são esclarecedoras e servem como ponto de análise para o assunto ora apresentado. Assim, vejamos:

1. Algo é arte porque é feito pelas mãos do homem; 
2. Porque essas mãos construíam algo como sendo único e deixavam neles suas marcas;

3. Esse algo, ao aparecer, era belo, sublime, significativo, ou simplesmente bom;

4. Porque seu valor era reconhecido institucionalmente, era legitimado. (tradução nossa)

Essas quatro implicações, segundo Duve (1998), foram desconstruídas, a partir dos anos 1960, e passaram a ser negadas em todos os seus respectivos aspectos, a saber:

1. A negação do trabalho enquanto objeto matérico - um tema desenvolvido por Lippard. (1997b, tradução nossa)

2. A negação de uma visão do trabalho como sendo o opus do artista - tema discutido por Roland Barthes. (1977, tradução nossa)

3. A negação do trabalho como sendo um fenômeno visual oferecido ao espectador, rejeição das práticas artísticas com base na morfologia, tema investigado por Kosuth. (1985 apud DUVE, 1998, p. 413-414, tradução nossa)

4. A negação do trabalho como valor institucionalizado, discutido através de Barry. (apud DUVE, 1998, p. 413-414, tradução nossa)

Os princípios de imaterialidade não estão associados a aspectos sociais e culturais, continuamente processados pela heterogeneidade das expressões visuais, bem como pela condição de desestabilização, abertura de ideias e maneiras de construir e pensar a arte. A noção que temos desse termo surge primeiramente como sendo algo inatingível. E o inatingível, o que é impermanente, como algo que não pode ser alcançado ou possuído, tem suas raízes na antiguidade, associado entre outras coisas, à alma. A ideia de opostos, sobretudo em corpo versus mente, ou seja, uma coisa tinha que ser uma ou outra. Por conseguinte, é importante ressaltar que a imaterialidade não é apenas transcendente, mas formas de pensamento e ações, presentes na experiência cultural, as quais, por sua vez, também são 
imateriais. Como produtos da mente humana, são expressões de diferentes imaginários coletivos e podem se expressar de formas invisíveis.

Lillemose (2006) dá ênfase à noção de imaterialidade, ao considerá-la uma terminologia própria do período tecnológico, assim com a arte materializada o foi para o período anterior a este. Lillemose recorre também ao conceito de desmaterialização, um dos primeiros termos a surgir no final da década de 1960, cunhado pela ativista e crítica norte-americana, Lucy Lippard, em Six years: the dematerialization of the art object from 1968 to 1972 (1997b). Neste texto, Lippard (1997b) nega o objeto arte do ponto de vista tradicional, isto é, pintura e escultura, tendo em vista a expansão da noção de materialidade, a partir da arte conceitual, uma nova forma de entender a arte fora dos moldes dicotômicos e opostos. Nesse sentido, vislumbramos uma extensão do paradigma pós-estruturalista do conhecimento humano, transportado para o campo das artes visuais, como era de se esperar. Um processo que implica surgimento de uma estética aberta e plural, sem limites e barreiras à construção da arte, seja ela material ou imaterial. Uma expansão que proporcionou maior liberdade de criar dentro dos padrões próprios de uma sociedade que iniciava um ambicioso projeto de globalização e comunicação. Partindo de uma transição da era industrial para a era tecnológica - momento em que a arte deixa de ser considerada como produção e passa a reprodução -, a arte torna-se independente de uma materialidade imposta. A definição do termo "desmaterialização" está diretamente associada aos conceitos já mencionados, como indeterminação, imprevisibilidade, bem como à inclusão de invenções científicas e tecnológicas, tempo e espaço real traduzidos materialmente ou imaterialmente, utilizando códigos e signos. Primeiramente, Lillemose (2006) considera esse processo como um tipo de ação - enquanto as outras estratégias são formas de condições e incompleto, pois a lista com nomes de artistas apresentada por Lippard parecia ampla e complexa, referindo-se a obras de Allan Kaprow, Richard Long, Eva Hesse, Lawrence Weiner, Sol LeWitt e Joseph Kosuth. Segundo esse autor, em primeiro lugar, essa arte não propõe o desaparecimento 
da materialidade, pelo contrário, a teoria de Lippard (1997b) propõe uma reflexão sobre uma multiplicidade de "materialidades", cuja interpretação leva Lillemose a considerar a desmaterialização como uma estética cuja concepção é sempre material. Quanto ao trabalho de Richard Serra, realizado entre 1967 e 1968, Lillemose (2006) esclarece que, por se tratar de uma lista infinita de verbos transitivos, Serra não estava interessado em dar forma a um objeto, mas experimentar o comportamento físico da matéria. Esse tipo de trabalho está associado à Antiforma, à Process Art, e envolve o deslocamento de materiais industriais do seu contexto funcional para o espaço da arte. Ao fazer uma comparação entre desmaterialização e imaterialização, Lillemose (2006) afirma que ambos são semelhantes em diversos aspectos, todavia pontua que enquanto a desmaterialização é um ato, imaterialidade é uma condição, ou seja, desmaterialização designa uma aproximação conceitual à materialidade, e a imaterialidade designa uma nova condição de materialidade, bastante atual nas experimentações com a arte tecnológica.

A crítica e historiadora da arte Mari Carmen Ramirez, diretora do International Center for the Arts of the Americas, localizado no Museum of Fine Arts, Houston, EUA, trabalha com o objetivo de divulgar a arte latino-americana contemporânea. Ramirez tem uma visão crítica a partir da repercussão (e suas consequências) causada pela introdução do termo "desmaterialização", utilizado por Lippard (1997b, p. 31) para descrever o caráter "obsoleto progressivo" da arte-objeto. Em primeiro plano, Ramirez (1992) atribui ao prefixo "des" um uso indevido, e faz uma crítica a esse plano, ao considerá-lo uma promessa não cumprida, não passando de um projeto revolucionário da neovanguarda eurocêntrica. No seu entendimento, a proposta de Lippard (1997b) vislumbrava um certo tipo de transformação da arte em simples ideias ou ações espontâneas por meio das quais prometia escapar para sempre da chamada síndrome da "moldura-e-pedestal". Ao ser libertada de um objeto, a arte estaria, portanto, desprovida de quaisquer funções decorativas e mercadológicas, e, ao negar o objeto arte, estaria também negando as instituições da arte, às quais Lippard (1997b) denomina cela branca. (tradução nossa) Entretanto, paradoxalmente, nos anos 
1980, a pintura renasce, contrariando as severas ameaças à sua morte, em variados estilos: neoExpressionismo, Transvanguarda, neoConceitualismo etc. Ramirez (1992, p. 156) se refere ao período pluralista, que surge nos anos 1980 (alguns autores o localizam nos anos de 1970), como sendo um período em que a arte desmaterializada converteu-se numa língua franca oficial e que alguns artistas latino-americanos:

Aceitaram o desafio imposto pela arte desmaterializada, mas em termos próprios e sob sua perspectiva particular. Em cada um dos casos, as suas obras, longe de serem consideradas apêndices derivativos dos paradigmas oficiais da arte mundial, estão preocupadas em sublinhar, no âmago, aquela diferença que articula suas diretrizes locais face à comunidade global. Para eles, a rota para uma prática independente da arte traçou-se por meio da apropriação e inversão do conceito original da arte desmaterializada. Isso foi possível, strictu sensu, porque o mito da desmaterialização nunca teve um seguimento acurado na América Latina. O que aconteceu foi, longe disso, uma re-materialização da arte. [...] A necessidade de contornar ou mesmo evadir a censura em países sob a mazela das ditaduras militares, ao mesmo tempo de garantir circuitos viáveis para a exibição de seus trabalhos, incentivou os artistas desde cedo a se engajarem em formas ideológicas de um conceitualismo baseado no objeto. [...] Essa forma de arte conceitual, alicerçada no uso de objetos previamente descontextualizados para transmitir novos significados, nasceu no nosso continente como um feito duplamente crítico: contra o sistema político local e contra os circuitos institucionalizados pela hegemonia do mainstream artístico. (tradução nossa)

De acordo com essa autora, os artistas latino-americanos utilizaram-se de objetos previamente descontextualizados para transmitir novos significados, com um objetivo crítico frente a um sistema político e contra os circuitos da arte internacional. Assim, o termo "rematerialização” pode ser encontrado, com aplicações diversas, a exemplo de Ascott (1996), que o utiliza para se referir à arte tecnológica, enquanto Ramirez (1992) 
o associa ao uso de materiais precários e a estratégias antiestéticas que reforçam formas não-tradicionais de produzir significado, na dissolução de qualidades, tais como o preciosismo ou o decorativo, ambos associados à tradição artística dirigida ao mercado.

Em depoimento à Universalis, ${ }^{1}$ Ramirez (1996a) informa que a obra desses artistas é caracterizada pela ênfase em dar novos significados aos materiais, seja por meio da mera reciclagem, seja por meio de uma forma de reutilizar diversas fontes de conhecimento da experiência contemporânea. A esse tipo de prática, tanto a matéria quanto o objeto não se deslocam da obra, eles passam a fazer parte integrante e principal da produção artística; denominada de poética da precariedade, o objetivo não é retirar esses signos do contexto cultural ou físico, mas, pelo contrário, expô-los como parte do próprio processo artístico, propondo reflexões sobre a precariedade do mundo. Nesse aspecto, a rematerialização passa a ser uma resposta à realidade dos países latino-americanos, que se ressentem desde o apoio oficial e institucional à falta de acesso a outros materiais. Um dos artistas, Ricardo Brey (1996), em entrevista dada à Universalis, expressa que em Cuba os artistas usam materiais pobres por motivos diferentes, sobretudo porque lá nunca se acham coisas novas, tudo está usado ou quebrado, assim como em muitos outros cantos do mundo.

\section{Multiculturalismo}

A cultura europeia exerceu uma influência profunda na arte, a partir do Renascimento, vindo, portanto, a determinar padrões de várias ordens. Os artistas fora do eixo europeu, como os das Américas, África e Oceania, ressentiram-se de sua inclusão na história da arte universal. E, assim, durante muitos séculos, foi esse o eixo que dominou o mundo das artes, sem que houvesse uma maior inclusão de outras civilizações, senão por meio daqueles que viajavam para terras distantes em busca de novas formas,

1 Universalis - Revista da XIII Bienal Internacional de São Paulo. São Paulo: Fundação, Bienal de São Paulo, 1996. 
ares, cores, odores, o que veio a ser considerado "exótico", dentre outros termos. Tratava-se de uma concepção eurocêntrica de mundo.

Já nas três últimas décadas do século $X X$, vislumbrou-se um interesse em todas as áreas do conhecimento humano em prol de um pensamento amplo, de significados múltiplos, que buscava romper com barreiras e limites, desde as questões mais presentes, como gênero, e que se estendeu ao planeta, ao homem e à natureza.

O “multiculturalismo", termo oposto a "etnocentrismo", é uma consequência do fluxo migratório de povos de outros países para os grandes centros ocidentais, do crescente desenvolvimento dos meios de informação e comunicação e do avanço tecnológico. Tem sido aplicado para descrever a crescente oposição às ideias inerentes ao pensamento ocidental sobre as obras de artistas de outros continentes, e aos vestígios deixados pela presença marcante do colonialismo nessas culturas.

Nas artes visuais, esse termo foi primeiramente aplicado em 1989, em decorrência da controvertida exposição "Les Magiciens de la Terre", do Centro Georges Pompidou, em Paris, onde trabalhos de renomados artistas aparecem junto a obras de todas as outras partes do mundo. Aparentemente celebrada, essa mostra provocou polêmicas discussões sobre a arte contemporânea mundial, desde o espaço reservado à exposição e à escolha dos representantes de cada país.

Para estudiosos desse assunto, os artistas de outros países (fora do circuito internacional de arte - América e Europa) continuam tendo pouca visibilidade. Porém, com o mundo globalizado, vários outros centros passaram a ter destaque, enquanto polos geradores de arte, como o Oriente - Japão, Coreia, Hong Kong, Cingapura -, através das grandes metrópoles asiáticas e países do leste europeu, após a queda do muro de Berlim.

Se, por um lado, o processo de globalização, sobretudo com o advento da Internet, passou a dar voz e visibilidade aos artistas fora do circuito predominante, por outro lado, suas obras raramente desfrutam da mesma liberdade de interpretação pelos críticos. Não obstante a questão identitária ser um dos componentes importantes da arte, existem outros fatores 
presentes em cada obra, senão uma marca constante de confinamento que passa a ser um estereótipo do exótico.

Lippard (2000) revela artistas até então fora do cenário artístico internacional, e assim considerados marginalizados e comumente denominados pejorativamente the others (os outros), termo que inclui negros, mulheres, povos indígenas, latino-americanos, africanos e outras ditas minorias. À luz de suas teorias, esses artistas são os representantes legítimos das diversas culturas a que pertencem e, por isso, merecem ser vistos. Tal consideração provoca polêmica e coloca uma interrogação, apresentada por Sandler (1996, p. 551): "[...] abrir as portas para uma sociedade mais justa, ou um novo tipo de tribalismo que voltaria a fragmentar a sociedade?" (tradução nossa)

Ao analisar a arte contemporânea latino-americana no contexto da era da globalização, Mosquera (1996) e Ramirez (1992) reconhecem que a identidade está condicionada à legitimação, ou seja, deve-se ao entendimento que eles possuem sobre a exigência de maior conscientização das desigualdades produzidas e dos intercâmbios de saberes, colocando esse continente como capaz de intervir na configuração de novos sistemas valorativos de ordem estética. Segundo eles, a circulação do simbólico deve estar contida numa produção como lugar de afirmação da suposta autonomia do campo artístico, para poder exercer seu poder hegemônico, transgressor de qualquer gesto dominante de poder. Em Beyond the fantastic: contemporary art criticism from Latin America, Gerardo Mosquera (1996) apresenta o mundo global como um paradoxo, visto que ele é, ao mesmo tempo, um mundo da diferença.

No contexto artístico internacional, as artes latino-americana e de outros países ainda permanecem analisadas à luz de diversas teorias, tendo a cultura da qual elas fazem parte como uma marca que as engessa em discursos meramente estereotipados e ilustrativos. Uma das consequências mais prejudiciais da colonização das chamadas culturas nativas pelos europeus é a interpretação de complexas estruturas culturais e mentais sob a luz difusa das fantasias étnicas do colonizador. Para esses pesquisadores, por muito tempo prevaleceu a ideia da descoberta de grupos curiosos, sem que a cultura desses grupos fosse devidamente entendida através 
de um prévio conhecimento do seu próprio povo. Metaforicamente, a desconstrução do espaço nas artes visuais também inclui o espaço cultural e social, visto que durante o período em que as técnicas tradicionais (pintura e escultura) foram desconstruídas, o conceito de espaço universal, meramente ocidental, foi pulverizado, abrindo portas e dando mais vozes ao que era apenas da ordem do particular.

Kosuth (1982) considera que o papel do artista é importante como divulgador de uma cultura, e na sequência delineia:

\begin{abstract}
A autenticidade da produção cultural do ser humano conectou seu momento histórico tão concretamente que a obra é experienciada como real; é a paixão da inteligência criativa com o presente, a qual informa tanto o presente como o futuro. Não é o significado do trabalho de arte que transcende o seu tempo, mas é o trabalho de arte que descreve a relação do artista com seu contexto através da luta em fazer significado. $\bigcirc$ trabalho de arte deve ser tão singularmente uma expressão concreta de indivíduo ou indivíduos que ultrapassa a individualidade, para se tornar parte de uma cultura que tornou aquela expressão possível. (KOSUTH, 1982 apud SANDLER, 1996, p. xxvii, tradução nossa)
\end{abstract}

Em busca de maiores informações sobre este assunto, encontramos um dos ensaios de Okwui Enwezor, intitulado Gabriel Orozco: silêncios infinitos (1995), escrito em Johannesburgo, e publicado em Atlántica Internacional: Revista de Arte y Pensamiento (1997), em que esse autor aborda a arte latino-americana da nossa atualidade através da arte do artista cubano, Felix Gonzalez-Torres, e do artista mexicano, Gabriel Orozco. Nas suas ponderações, Enwezor (1997) destaca aspectos que vão além de uma crítica cultural, incluindo a maneira pela qual a obra foi construída com seus respectivos materiais, os diferentes espaços que ela ocupa, bem como um entendimento do ponto de vista semiótico.

Inicialmente, Enwezor (1997) apresenta a arte de Felix Gonzalez-Torres, reconhecido como um dos expoentes das artes minimalista e conceitual, 
de um ponto de vista mais amplo, sem ignorar as próprias vivências de um artista cubano que conseguiu romper as barreiras que separavam o público das experiências de vanguarda mais radicais. $\mathrm{Na}$ instalação - Sem-título - da série Placebo (1991) -, que consiste em um grande tapete formado por caramelos enrolados em papel, podemos observar o uso de objetos do cotidiano, cujo tema Enwezor (1997) sutilmente assinala como um gesto de generosidade do artista e um desafio às regras tradicionais e à etiqueta museológica; uma espécie de gesto. Por se tratar de obras efêmeras, conceituais, elas devem ser lidas por meio de uma crítica internacional, em que a identidade do artista não é apenas o conteúdo da obra, senão sua vivência, e o conhecimento que ele possui da história e da teoria da arte.

Quanto à obra de Gabriel Orozco, Enwezor (1997) versa sobre a utilização de materiais e a transfiguração do espaço do ponto de vista semiótico. Ao usar objetos e situações do ambiente urbano contemporâneo, Gabriel Orozco torna visível a poesia de conexões, possibilidades e paradoxos. Nas fotografias desse artista, por exemplo, materiais encontrados ou cenários são registrados, e pela observação do artista (ou sua intervenção), ele transporta aspectos do cotidiano. Seu interesse em cartografia e geometria é evidente em trabalhos como $O$ Atomista, obra composta por uma série de imagens esportivas recortadas de jornais, sobrepostas por elipses e esferas coloridas, formas que fazem parte essencial do seu vocabulário visual. Enwezor (1997) acredita que, em muitos aspectos, as causas que o destacam do grupo de artistas jovens da cena internacional são exemplificadas pelo fato de existir no seu trabalho certa reciprocidade entre a formação vernacular e a sofisticação cosmopolita.

Algumas características das obras de Robert Smithson, Joseph Beuys, Marcel Duchamp, Cildo Miereles, Hélio Oiticica, Ana Mendieta, Gordon Matta-Clark e Felix Gonzalez-Torres são também facilmente aplicáveis à obra de Gabriel Orozco, não obstante este artista trabalhar com aspectos da contemporaneidade e identidade com fidelidade e consciência dupla, sem que isso implique numa consciência antagônica, mas complementar.

O que dá magnificência à sua produção artística é sua natureza do fugidio, que ocupa com precisão delicados momentos longos, de silêncio, 
e instantes de hilaridade. Ao lado destas suas ações, encontra-se a reordenação social e sensorial de nossas percepções, transformando numerosos objetos que acreditaram ser esculturas e instalações fora de seu significado original. Não obstante Gabriel Orozco ter um interesse particular pelos objetos de cultura que extrapolam a sua, a partir da perspectiva da vida cotidiana de outros povos, ele constrói um discurso visual sutil, inspirado no comportamento de determinadas classes trabalhadoras. Ademais, a obra de Orozco propõe uma descentralização de territórios de acesso restrito, ao produzir espaços híbridos, considerado por Enwezor (1997) como uma união improvável de oponentes, ou um possível encontro de duas comunidades, quando ele mistura na sua obra objetos que fazem parte de outras classes sociais com espaços suntuosos da aristocracia.

Numa de suas instalações, intitulada Empty Club, St. James Street (1996), criada através da apropriação de um edifício em Londres, o artista esvazia o espaço de seus próprios objetos e os substitui por outros pertencentes a outro contexto. Esse trabalho, que se constitui pela troca de objetos específicos de duas classes sociais distintas, instaura, além do gesto invisível do artista, um estranhamento, pelo contraste entre objeto e espaço, colocando - observador para refletir sobre a sua própria condição e conduta social. Uma das características de sua arte é o tom que sustenta as leves alterações de contextos, situações, imagens e objetos, sobretudo as obras realizadas na década de 1990. São instalações, esculturas, fotografias, dentre outras práticas artísticas, nas quais Orozco busca alterar a função dos objetos ordinários, ao conferir-lhes um novo significado. Uma das obras mais conhecidas e celebradas desse artista, intitulada La DS (1993), é um automóvel Citröen, cor de prata, que foi fatiado em três pedaços ao comprido. A peça do meio foi removida, e as duas formas restantes unidas formando um carro tipo flecha, com a largura de $63,5 \mathrm{~cm}$ menor do que o original. Os visitantes podem entrar e se sentar nesse novo carro; suas portas e o porta-malas abrem e fecham, muito embora esse carro não possa ser dirigido. Enwezor (1997) considera La DS de Orozco como um dos ícones mais sedutores do projeto contemporâneo: o clássico Citröen cor de prata DS, criado no final dos anos 1950, foi convertido em peça de museu. 
Nessa obra, o gesto de Orozco está na transformação do símbolo de velocidade e sedução metropolitana em um feito escultural, e seu autor tem sido amplamente associado à arte do artista americano Gordon MattaClark, que, de uma forma semelhante, trabalhou na série Anarquitetura (meados dos anos 1970) com ações de fragmentação, ao cortar partes de uma casa em New Jersey, EUA. Além das partes recortadas, apresentadas como objetos, várias fotografias integram esse projeto, não apenas com o objetivo de documentar o processo, mas a fotografia como linguagem visual independente.

A obra de Gabriel Orozco inclui também o uso da fotografia para registrar suas performances e intervenções, não apresentadas ao público, ou seja, são ações consideradas solitárias e pessoais feitas para registrar sua influência numa paisagem ou em outras situações do cotidiano. Por serem realizadas de uma forma mais intimista - as performances e as fotografias -, Enwezor (1997) as associa às performances de Ana Mendieta. Segundo este autor, essas obras propõem um jogo semiótico e estético, a partir do conceito de ausência, em que o observador se situa entre o sujeito observador e o objeto da representação. Com a reprodução mecânica, o fotógrafo faz com o objeto o mesmo que faz com outras técnicas tradicionais, como a gravura ou a água-forte. Porém, essas técnicas se propõem, ainda, a reproduzir um gesto anterior. Contudo, a fotografia, como meio de percepção, baseia-se na transformação química de um gesto mimético, a gravura e a água-forte se fundamentam na transformação de uma superfície física em signo, o que, ao mesmo tempo, acentua o referente físico e valoriza sua ausência na reprodução.

Krauss (1985, p. 152) argumenta sobre o conceito de origem, original, cópia e múltiplos. Parafraseando Walter Benjamin (1990), considera que "a autenticidade se esvazia como conceito na medida em que se aproxima destes meios inerentemente múltiplos”, e que:

[...] a noção de autenticidade do momento da performance nas fotografias de Orozco se experimenta também como performances repetidas, múltiplas, como cópias carentes na aparência de uma fonte original, 
sempre frescas, novas e imediatas. Por isso, não se trata apenas de um signo paradoxal, pois no caso de Orozco toda performance, intervenção e ação são sempre prévias e não podem experimentar o signo como crônica ou marca esquemática desenhada no espaço vazio do objeto: o original agora aparentemente perdido. (tradução nossa)

Para Gabriel Orozco, o mais importante não é apenas o que as pessoas veem na galeria ou no museu, mas o que as pessoas veem depois de olhar essas coisas, como confrontam a realidade outra vez. Porém, sua arte nos leva também a refletir sobre as inúmeras estratégias das artes visuais contemporâneas, bem como nos remete à infindável questão - o que é arte? - o que em muito poderá contribuir para futuras reflexões sobre as obras de outros artistas.

\section{Paradigma da Matéria}

No final da década de 1960, materiais de origem sintética, industrial, como látex, pigmentos acrílicos brilhantes, espuma, plásticos, borracha, dentre outros, ao serem aplicados a obras, passaram a ser associados ao tecido do corpo humano, provocando, de imediato, uma sensação de extensão tátil corporal e contrapondo-se à frieza do minimalismo.

Denominada de pós-Minimalismo, termo cunhado por Pincus-Witten (1987, p. 34), ou Process Art, essa prática tem como objetivo apontar para o comportamento imprevisível da matéria. Para o artista Robert Morris, "as barreiras entre formalismo e Antiforma descrevem as esculturas espalhadas e outros objetos não ortodoxos" (apud PINCUS-WITTEN, 1987, p. 47, tradução nossa), e, durante essa época, materiais industriais permitiam a interação entre espaço, massa e gravidade, assim como a ideia da forma continuamente mutante.

Dentre os artistas que mais se destacaram nesse período, temos os americanos Bruce Nauman, Eva Hesse, Lynda Benglis, Louise Bourgeois, Robert Morris e Richard Serra, semelhantes e diferentes entre si pelo 
número de múltiplos sistemas estéticos por eles construídos. Enquanto Eva Hesse transfere para sua arte a ideia de contradição de opostos, sobretudo ordem versus caos - atração de polaridades associadas à sua condição psíquica -, Benglis insiste na busca de algo tátil no seu próprio corpo. Por outro lado, Richard Serra se interessa pela relação entre o aspecto físico e pontos precários de tensão causados pelas propriedades dos materiais entre si, assim como pelos procedimentos artísticos que resultam na forma, através de processos operacionais do tempo e ação, gravidade, peso e equilíbrio. Robert Morris, empenhado em descrever o processo, associa materiais a ações, contrapondo-se à ideia de forma fixa, em busca de uma racionalidade intelectual. Seu principal objetivo era a observação do comportamento e o desdobramento de formas a partir da maneira natural pela qual esses materiais se espalham pelo chão, pendentes do teto à procura do imprevisível, a depender do espaço ocupado. Embora cada um desses sistemas estéticos se apresentassem como autônomos, com suas próprias referências e especificidades, juntos, eles fizeram parte do grupo de artistas que, no período entre 1960 e 1970, sofreram influências de John Cage e Merce Cunningham, pela presença do movimento e da ação.

Da mesma forma que em outras regiões do planeta, na Europa, esse período foi tão efervescente em questões sociais e políticas voltadas para a natureza, a terra, o homem e seus direitos, gerando posturas e posicionamentos críticos. Temos, assim, a reação de artistas americanos contra a comercialização da arte, a objetividade do minimalismo e a arte corporativista, que não se distanciavam da visão de artistas de outras nações. Os italianos, insatisfeitos com os valores estabelecidos pelas instituições governamentais, pela indústria e cultura, expressaram, através de materiais ordinários, os seus mais contundentes protestos, dando origem a uma arte que veio a ser conhecida como arte povera, termo cunhado por Germano Celant (1969), autor do influente livro Arte povera: conceptual, actual or impossible art? e de duas significativas exposições, em 1967 e 1968. Foi ele também um dos mais importantes divulgadores dessa arte, considerada revolucionária, livre de convenções, distante do poder das estruturas... e do mercado. Diferentemente das experimentações com a matéria, realizadas 
pelos americanos, os europeus, impregnados pela sua tradição cultural, encontraram nessa arte um meio para desafiar normas e regras, e embora o objetivo de Celant (1969) não tenha sido rotular nenhum grupo individualmente, esse termo não se projetou em âmbito internacional e foi aplicado apenas a um grupo de artistas italianos, a exemplo de alguns nomes que mais se destacaram, descritos a seguir. Jannis Kounnellis associa a presença do fogo nos seus trabalhos à legenda medieval, significando punição e purificação. Gilberto Zorio trabalha com alquimia, evaporação de álcool ou ácido, explorando a estética do visível e do invisível. Guiseppe Penone, ao pressionar seu próprio corpo numa fôrma de barro, moldando-o à terra, realiza uma obra que envolve o corpo do artista, matéria e ação. Durante o processo final em que ele libera sua respiração, esse ar dá vida a um corpo que não mais existe, mas ali está o seu registro. Por sua vez, Mario Merz, por meio da fusão de materiais naturais com detritos da sociedade urbana, levanta questões sobre a natureza e a cultura, e a noção de que a obra não é transcendente, mas, como qualquer outra forma de vida, é uma identidade que contém ideias. Seus reconhecidos igloos expressam os principais fundamentos da existência humana, sobretudo nos princípios da série de Fibonacci. Nesse contexto, o pensamento matemático e intelectual invisível é concretizado em pedra, jornais, neon, cimento etc.

No Brasil, Chiarelli (1997) entende que, nesse período, a arte brasileira também esteve voltada para esse tipo de experimentação devido à influência de outras tendências internacionais, como a arte povera e a Antiforma.

Do mesmo modo que Duchamp influenciou a arte contemporânea internacional, a figura de Hélio Oiticica foi um dos principais marcos, com suas manifestações ambientais, que deram origem à obra Parangolé, iniciada a partir de 1964. Nesses trabalhos, as ações caracterizadas como "efêmeras" comungavam com a investigação da matéria. Dentre outros, Arthur Barrio, em Trouxas ensanguentadas, insere a obra no circuito urbano, onde o artista passa de criador a participante, ou seja, como ser anônimo divide com transeuntes a experiência de se deparar com sacos plásticos contendo sangue, ossos, saliva, unhas. Para o público em geral, o conceito de arte está muito distante desses objetos que mais se assemelham a detritos. Pelo fato de o 
Brasil estar atravessando um dos momentos mais marcantes politicamente, sua obra é identificada com uma crítica à ditadura militar.

Assim como a matéria bruta, a industrializada e outros elementos que extrapolam quaisquer designações, a sua ausência atraiu alguns artistas em nome dessa arte efêmera, imaterial, que em muito se aproxima das cartografias, dos mapas, da geografia etc. Um dos exemplos mais expressivos encontra-se na obra do artista americano Richard Long, que se configura em um tipo de arte denominada walkscape, termo usado por Careri (2002).

Para Careri (2002), o caminhar faz parte da arquitetura da paisagem: andar é como uma forma autônoma de arte, que se objetiva pela transformação simbólica de um território; um instrumento estético de conhecimento e uma transformação física do espaço, observados desde o nomadismo até a nossa atualidade. É uma forma de experienciar um lugar, perceber a paisagem, deixar marcas num local. A partir da obra Five six pick up sticks (1980), Richard Long (apud STILES e SELZ, 1996, p. 563-566), descreve seu processo de trabalho que consiste no caminhar em lugares diversos, observando a natureza; o caminhar expressa a liberdade; o caminhar é mais uma outra camada, um marco, dentre milhares de outras camadas de história geográfica do homem. (tradução nossa)

Para muitos artistas que trabalham nessa linguagem, a obra se constitui em um simples ato de andar, reconhecer o próprio corpo em movimento e sua relação com o espaço em que ele circula, seja na cidade ou em meio à natureza.

\section{A Crise do Espaço nas Artes Plásticas}

\section{Escultura}

Ille simul manibus tendit divellere nodos perfusus sanie vittas atroque veneno, clamores simul horrendos ad sidera tollit: qualis mugitus, fugit cum saucius aram taurus et incertam excussit cervice securim. ${ }^{2}$

Virgílio, 1879

2 Ele em trincar os nós com as mãos forceja,/E de horrendo bramido aturde os ares:/Qual muge a rês ferida ao fugir d'ara,/Da cerviz sacudindo o golpe incerto./Vão-se os dragões serpeando ao santuário,/E aos pés da seva deusa, enovelados,/Sob a égide rotunda ambos se asilam. 
A consulta a enciclopédias sobre o termo "escultura" nos leva a diversos significados e fatos-exemplo, dentre os quais está a estatuária grega, representando o ápice dos padrões já atingidos pelo homem: o antropomorfismo. O equilíbrio, a perfeição das formas e o movimento, obtidos por meio de materiais que deram forma a figuras de homens de grande proporção, e cuja postura passou por alguns estágios, desde o kouros, às estátuas que mostravam o homem em movimento. E os gregos buscaram cada vez mais desenvolver essa técnica, tendo o homem como forma padrão, representando, além da idade, sua personalidade, suas emoções e estado de espírito, graças a grandes escultores, como Policleto, Fídias, Praxíteles, Miron e Lisipo.

Para Wittkower (2001, p. 4):

Os gregos, herdeiros das civilizações orientais, e depois deles os romanos e italianos, cultivaram com orgulho as tradições que remontam a uma época imemorial, e foi no seio dessas civilizações mediterrâneas que surgiu o conceito de que esculpir a pedra, especialmente o mármore, era o objetivo mais elevado e a mais grandiosa realização dos escultores.

$\mathrm{Na}$ escultura grega, priorizava-se o caráter de antropomorfização da divindade no interior da obra, ou seja, a presença marcante dos seus deuses, como indivíduos definidos, tornando-se caracteristicamente importante o processo de idealização da arte como primeira esfera do espírito absoluto. Nos deuses, tanto para os poetas quanto para os escultores, a antropomorfização estava no limite entre o divino e as formas naturais e as paixões, além da forma ideal de beleza.

A Historia naturalis (volume XXXVI), de Plínio, faz referência à estátua Laocoön (^aокówv), do século I a.C., também conhecida como $O$ mote de Laokoön (1766) ou O grupo de Laocoonte. Esculpida por Agesandro, Atenodoro e Polidoro, mostra uma cena mitológica, descrita por Virgílio, em sua Eneida, na qual o sacerdote troiano Laocoonte tenta salvar seus filhos de duas serpentes.

Uma das mais estudadas obras, inspirou estudiosos desde um dos maiores escritores alemães do século XVIII, Gotthold Ephraim Lessing 
(1766), passando Clement Greenberg (1940), Michael Fried (1998) a Rosalind Krauss (2001), dentre outros.

No ensaio a Lacoonte, Lessing (1957 apud KRAUSS, 2001, p. 2-6), realçando a monumentalidade da estética helenística, enfatiza as propriedades de cada arte em função de seu meio expressivo, tendo como ponto de partida a poesia e a pintura.

Greenberg (1940), crítico de arte americano - que dedicou seus estudos ao modernismo por quase meia década - vai legitimar as teorias de Lessing (1957 apud KRAUSS, 2001, p. 2-6), no que diz respeito à pureza das técnicas, sobretudo à pintura, ao declarar a necessidade dos artistas em colocar uma nova ênfase na forma e abandonar completamente o público.

Fried (1998, p. 134) vai se aproximar das teorias greenbergianas e trabaIhar, na defesa do conteúdo formal, próprio da pintura, a importância das características desse meio peculiar, frente a um período repleto de "novas" práticas artísticas, que rompiam com os códigos tradicionais de cada técnica. O foco de suas inquietações foi o Minimalismo, quando, em defesa da pureza de cada técnica, Fried observa que "a adoção literal da objetidade nada mais é do que um apelo a um novo gênero de teatro; e o teatro é hoje a negação da arte". Essa posição de Fried se aproxima do pensamento de Lessing (1957 apud KRAUS, 2001, p. 3) sobre a escultura como uma forma de arte relacionada com a disposição dos objetos no espaço, e, por conseguinte, "é preciso distinguir entre esse caráter espacial definidor e a essência das formas artísticas, como a poesia, cujo veículo é o tempo".

Se a representação de ações no tempo é natural na poesia, não o é à escultura ou à pintura, pois o que caracterizava as artes plásticas era o fato de serem estáticas. Em decorrência dessa condição, as relações entre as partes isoladas de um objeto visual, oferecidas simultaneamente a seu observador, estão ali para serem percebidas e absorvidas em conjunto e ao mesmo tempo. Com essas considerações Lessing (1957 apud KRAUSS, 2001, p. 2-6) posiciona-se contra o entendimento de que a pintura é uma poesia muda e a poesia uma pintura falante.

Krauss (2001, p. 5-6), ao se referir às noções de espaço e movimento na escultura, provocadas pela transposição e ampliação de práticas visuais 
em espaços até então ainda intocados pela arte, vai observar que, para Lessing (1957),

Todos os corpos, entretanto, existem não apenas no espaço, mas também no tempo. Eles continuam e podem assumir, a qualquer momento de sua continuidade, um aspecto diferente e colocar-se em relações diferentes. Cada um desses aspectos e agrupamentos momentâneos terá sido o resultado de um anterior e poderá vir a ser a causa de um seguinte, constituindo, portanto, o centro de uma ação presente.

Krauss (2001, p. 3-4) apresenta também as teorias de Giedion-Welcker (1956) sobre a escultura do século XX, publicadas no livro Modern plastic art, no qual esta última autora se refere à "crescente pureza com que a escultura foi concentrada em seu caráter espacial - à exclusão de quaisquer outras preocupações”, observando ainda que, para Giedion-Welcker (1956),

Os recursos espaciais da escultura em termos de significado originavam-se naturalmente do fato de ser ela composta de matéria inerte, de modo que sua própria base implicava na extensão no espaço e não no tempo. [...] Essa matéria inerte é um sistema de configuração imposto a ela, de modo que se estabelecia, no espaço estático e simultâneo do corpo escultural, uma comparação entre duas formas de quietude: a substância densa e imóvel do objeto e um sistema lúdico e analítico que aparentemente the havia dado forma.

As teorias de Krauss (2001, p. 6) sobre a escultura moderna partem da premissa de que:

Mesmo em uma arte espacial, não é possível separar espaço e tempo para fins de análise. Toda e qualquer organização espacial traz no seu bojo uma afirmação implícita da natureza da experiência temporal. [...] A escultura é um meio de expressão peculiarmente situado na 
junção entre repouso e movimento, entre tempo capturado e a passagem do tempo. É dessa tensão, que define a condição mesma da escultura, que provém seu enorme poder expressivo.

\section{Temporalidade e Duração da Experiência}

Até o último estágio do período modernista, também conhecido como "alto modernismo", a divisão entre artes plásticas, espaço e tempo não foi, em certa medida, devidamente identificada. Fried (1998), na esteira de Greenberg, deu prioridade, sobretudo no seu artigo Art and objecthood, a críticas a esse período, ao pontuar questões relativas à dependência da mudança de ambiente e, concomitantemente, à falta de autorreferência. Para esse autor, o objeto se apresentava como um palco e o observador como um ator, fazendo com que a arte se tornasse "teatral", isto é, experienciada no tempo. Fried (1998) argumenta que, ao abordar características da arte teatral, essas novas práticas não estavam apenas negando o modernismo, mas todas as artes em geral. Por sua vez, Crimp (1979) entende que a preocupação de Michael Fried não era apenas a localização perversa entre pintura e escultura, mas sua preocupação com o tempo, mais precisamente com a duração da experiência. Foi, portanto, nesse contexto, que artistas passaram a experimentar espaços até então não explorados, ou seja, o que veio a ser conhecido mais tarde como "campo expandido", termo cunhado por Rosalind Krauss.

Para Krauss (1990, p. 31), o "novo" na arte é algo que sempre provoca desconforto, e a fim de transformá-lo em um sentimento confortável, e mais familiar, vários pesquisadores tentam apresentá-lo como algo que vem gradualmente se desenvolvendo a partir de formas do passado. Deste modo, exemplifica com o historicismo, tendência que, segundo ela, trabalha com a novidade para dirimir a diferença, ao criar um espaço na nossa experiência que evoca um modelo de evolução. Foi no período que compreende a passagem da década de 1960 para 1970, que algumas coisas chamaram a atenção na arte, ao serem denominadas esculturas, a exemplo de corredores estreitos com monitores de TV enfileirados; grandes fotografias documentando caminhadas no campo; espelhos dispostos 
em ângulos estranhos em salas comuns; linhas temporárias cortadas no solo de desertos etc. De fato, nenhuma dessas expressões se assemelhava à categoria tradicional de escultura, a não ser que essa categoria pudesse se tornar quase que infinitamente maleável.

As críticas que acompanharam a arte americana do período pós-guerra trabalharam a serviço dessa manipulação, ou seja, nas mãos dessas operações críticas, categorias como escultura e pintura foram amassadas, esticadas e torcidas numa extraordinária demonstração de elasticidade. Do mesmo modo que qualquer coisa passou a ser considerada arte, um termo cultural por sua vez pode ser também ampliado e receber inclusões sem nenhum critério. Segundo Krauss (1990), o termo "escultura" tornou-se cada vez mais difícil de ser pronunciado, mas não impossível. Alguns especialistas recorreram a um passado muito mais distante do que décadas, a datas milenares, para construir um discurso genealógico. Portanto, Stonehenge, linhas Nazca, ballcourts do período Maia-Toltec etc. foram usados como exemplos de semelhança. Entretanto, para Krauss (1990), a tentativa de encontrar uma semelhança no vocabulário histórico tornaria o estranho, confortável, podendo, assim, legimitizar essas obras como sendo esculturas, o que, contudo, não foi suficientemente convincente. Não obstante essa prática ser ainda aplicada por alguns teóricos - a busca do passado para justificar algo novo no presente - o fato fez com que o termo "escultura" se tornasse obscuro, isto é, o uso de categorias universais para autenticar um determinado grupo de particulares não poupou a categoria de se tornar enfraquecida, ao ser forçada a cobrir uma heterogeneidade tão ampla como a que se apresentava naquele momento.

Conforme Krauss (1990, p. 33), independente desses discursos, a escultura é uma categoria historicamente uniforme e não uma categoria universal. Assim como qualquer outra convenção, ela possui sua própria lógica interna, suas próprias regras e não está aberta a muitas mudanças. "A lógica da escultura, por conseguinte, parece ser inseparável da lógica do monumento", e, em virtude desta lógica, a escultura é uma representação comemorativa. Apóia-se num espaço particular e fala uma língua simbólica sobre o significado ou uso desse lugar. De acordo com as considerações 
dessa autora, que se seguem, podemos acompanhar o processo de desconstrução do espaço lógico da escultura.

Um dos principais exemplos dado por Krauss (1990) é a estátua equestre de Marcus Aurelius, um monumento situado no centro do Campidoglio para representar, por sua presença simbólica, o relacionamento entre o antigo Império Romano e o lugar do governo moderno. Assim como outros monumentos, ele possui uma lógica interna que funciona como representação de algo, é um signo, visto que é o monumento que marca um lugar particular para um evento ou significado específico. Por funcionarem assim, em relação à lógica da representação e da marcação, as esculturas são normalmente figurativas e verticais, seus pedestais são partes importantes da estrutura, pois são eles que fazem a mediação entre o local real e o signo representacional. Krauss (1990, p. 36) entende que não há nada de muito misterioso nesta lógica, fonte de uma enorme produção de esculturas durante séculos da arte ocidental. Mas a convenção não é imutável, e então veio um tempo em que a lógica começou a fracassar, e a escultura passou a ser até algo em que você tropeça, e que não faz realmente parte da paisagem. Nesse processo de desconstrução, a escultura estava na categoria da adição da não-paisagem à não-arquitetura e esculpir havia se tornado um tipo de ausência ontológica, a combinação de exclusões, a soma do "nem isso nem aquilo".

A proposta de Krauss (1990, p. 38) para poder pensar o complexo, está na admissão, no reino da arte, de dois termos que anteriormente haviam sido sido proibidos: paisagem e arquitetura. Vejamos suas considerações:

Não havia sido possível anteriormente pensar e assimilar o complexo, embora outras culturas houvessem entendido este termo com grande facilidade. Os labirintos são tanto paisagem como arquitetura, os jardins japoneses são, ao mesmo tempo, paisagem e arquitetura, e os campos de jogos de rituais processuais das civilizações antigas foram, neste sentido, ocupantes inquestionáveis. O que não significa dizer que eles foram formas variantes antigas nem degeneradas da escultura. Faziam parte de um universo ou espaço cultural em que 
escultura era simplesmente outra parte - não de qualquer maneira, como nossas mentes historicistas o conceberiam como sendo o mesmo. Seu propósito e prazer são exatamente que são opostos e diferentes. [...] A escultura não era mais um termo intermediário privilegiado entre duas coisas. A escultura é antes só um termo na periferia de um campo em que há outro, de forma estruturada, de possibilidades diferentes. E assim ganhou a permissão de se pensar nessas outras formas. (tradução nossa)

Como podemos observar, a escultura passa a fazer parte de um campo, que rompe com as primeiras dicotomias da não-paisagem e da não-arquitetura. Para poder nomear esta ruptura histórica e a transformação estrutural do campo cultural que caracterizou esse período, Krauss (1990) menciona a necessidade de recorrer a outro termo. Como o termo que já estava sendo aplicado nesse período em outras áreas era o "pósmodernismo", essa autora considera que não há nenhum problema em utilizá-lo para descrever essas práticas que estavam acontecendo com o nome de escultura. Similarmente, outras surgiram ampliando cada vez mais as possibilidades do artista trabalhar com quaisquer tipos de materiais e espaços. Consequentemente, termos - como marked sites, marcas - emergiram para designar obras que podem ser ao mesmo tempo impermanentes, fotográficas ou assim como uma instância política para marcar um determinado lugar. Parece claro que esta permissão ou pressão para se poder pensar no campo expandido foi sentida por um número de artistas de uma mesma geração, entre os anos 1968 e 1970, como Robert Morris, Robert Smithson, Michael Heizer, Richard Serra, Walter De Maria, Robert Irwin, Sol LeWitt, Bruce Nauman, Robert Irwin, Alice Aycock, John Mason, Michael Heizer, Mary Miss, Charles Simonds, dentre outros, que introduziram novas condições lógicas que não mais podiam ser descritas como modernismo.

Para o pós-modernismo, a prática não é definida em relação a um determinado meio, como a escultura, mas em relação às operações lógicas existentes num jogo de termos culturais, como fotografia, livros, espelhos 
etc. Assim, um artista pode ocupar e explorar diversas possibilidades que não são ditadas por quaisquer condições de um meio qualquer. Krauss (1990, p. 40) conclui suas considerações elucidando que a transformação da escultura moderna se deu por ideias de passagem, referindo-se a obras que propõem esse tema, como Robert Morris, Richard Serra e Quebra-mar, de Smithson, permitindo que a escultura fosse vista não mais como um veículo estático e idealizado, mas como um veículo temporal e material.

Santaella (2003a) considera Duchamp como um dos primeiros artistas a apresentar um objeto-signo para a arte, o que, mais tarde, na contemporaneidade, sobretudo depois da Segunda Guerra Mundial, a arte faz brotar as mais diversas expressões, como instalações, apropriações etc., ao que a referida autora denomina como sendo um período de "paisagens sígnicas" (nome que nos inspirou como título deste livro).

\section{Earth Art}

Um mundo descolorido e fraturado cerca o artista. Organizar esse monte de corrosão em padrões, grades e subdivisões é um processo estético que mal tem sido tocado.

Robert Smithson, 1968

A maioria da arte descrita por Krauss (1990) se refere ao que veio a ser chamado de Earth Art, obras que muitas vezes necessitam de uma "enunciação": "isto é arte", para que sejam vistas como tal. Caso contrário, elas passam despercebidas e confundidas com meros montes de terra, pedras, madeiras, areia etc., num determinado campo. Assim, ainda que nesta abordagem sobre o processo de desconstrução da escultura, à luz das teorias de Krauss (1990), esteja inserida a Earth Art, devemos aprofundar outros conceitos complementares.

Smithson (1998) fala do conceito de sedimentação, e descreve as mentes humanas e a natureza. Para ele, tanto a mente do homem como a mente da terra está em constante estado de erosão; a mente dos rios desgasta seus bancos; o cérebro subverte os despenhadeiros do pensamento; as ideias decompõem-se em pedras desconhecidas; e as cristalizações conceituais tornam-se pó. Para Smithson (1998), os materiais não são 
sólidos, todos eles contêm cavernas e fissuras, são superfícies prontas a racharem a qualquer momento. Seu pensamento arqueológico difere dos conceitos e noções tradicionais sobre o tempo linear. Para ele, o tempo transforma todas as coisas, e a matéria está sujeita a todas as mutações. Com esse pensamento, Smithson acredita que a arte deve explorar as mentes pré-históricas e pós-históricas, e deve ir a lugares onde o futuro remoto possa encontrar o passado remoto.

Nesse sentido, uma das premissas confirma que a Earth Art surge em decorrência da aceleração comercial de que a arte passou a desfrutar, a partir dos anos 1950 até 1980. Durante essa época, obras de pintores expressionistas abstratos estavam sendo adquiridas por colecionadores e museus a preços exorbitantes, o que levou muitos artistas a considerarem esse fato como um elemento negativo. Assim, aqueles que se opuseram a acompanhar a explosão provocada no mercado financeiro das artes buscaram trabalhar em espaços alternativos (a terra, os campos, desertos, entre outros, da vida cotidiana), isto é, espaços fora do circuito tradicional e institucionalizado - como galerias e museus -, lugares onde eles pudessem materializar suas ideias. A arte realizada nesses novos espaços fugia do conceito tradicional de objeto arte e era, na maioria das vezes, efêmera, sendo sua duração determinada apenas pelo próprio tempo da natureza, ou pela proposta do artista.

Muitos autores, filósofos e poetas se referem ao retorno do homem à natureza, a exemplo de Carlin e Fineberg (2005), que apresentam a opinião desses artistas sobre o espaço que eles ocupam na natureza e no mundo ao seu redor. No início do século $X X$, a América iniciou uma aventura diferente de qualquer outra nação na história, com uma vasta fonte de recursos naturais, grandes invenções e um enorme influxo de pessoas de várias partes do mundo, que fizeram com que ela se tornasse o berço de um novo tipo de experiência humana.

Para Sandler (1996, p. 61-62), a Earth Art sofreu influência da Process Art devido ao uso de elementos naturais, sugerindo um novo tipo de paisagem, pois os materiais utilizados nessa arte, em sua maioria substâncias encontradas na natureza, eram impermanentes, indeterminados e mutáveis. 
E mesmo que os artistas tenham se empenhado nessa nova estética, foram muitas as críticas que surgiram. (tradução nossa)

De acordo com Spies (1982, p. 269-270), os espaços escolhidos e seus propósitos são lugares remotos de iniciação: uma conjuração mágica do sublime. Para esta abordagem, destacamos o escultor americano Walter De Maria e sua obra The lightning field [Campo relampejante] (1977), situada numa área do deserto do Novo México, nos Estados Unidos. Composta por 400 postes de aço inoxidável polidos e instalados na forma de um avião, no sentido horizontal, só pode ser visualizada do alto, ou seja, sobrevoando-se a área. Concebida geometricamente, sua localização determina características, como privacidade, mistério, tempo, a expectativa de apresentação dos fenômenos da natureza (raios, trovões, tempestades). Além disso, trata-se de uma arte que só pode ser experienciada em partes e nunca em sua totalidade. Ainda descrita por especialistas como escultura (note-se que esse termo ainda continua sendo aplicado), os visitantes são encorajados a permanecer por bastante tempo nesse lugar, especialmente durante 0 entardecer e o alvorecer.

Como um projeto da DIA Art Foundation ${ }^{3}$ há incentivos a visitas, durante os meses de maio a outubro, quando o visitante tem acesso a acomodações e infraestrutura próprias. Todavia, embora o período de visita coincida com a época em que ocorrem os raios nessa área - como o seu próprio título (The lightning field) sugere -, não apenas esse fenômeno está presente na obra. Segundo informações dessa fundação, existem outras qualidades a serem experienciadas nesse ambiente, uma delas podendo ser a própria expectativa do acontecimento desse fenômeno, sua própria possibilidade.

As obras que envolvem a Terra, ou seja, os projetos de Earth Art remetem a fenômenos da natureza, com o objetivo de criar situações onde a paisagem e a natureza, luz e previsão de tempo tornem-se intensas

3 Instituição americana sem fins lucrativos, fundada em 1974, e internacionalmente reconhecida pelo trabalho de incentivar, apoiar, apresentar e conservar projetos de arte, sobretudo aqueles que, pela sua natureza e escala, extrapolam os limites normalmente estabelecidos segundo a tradição de museus e galerias. 
experiências de ordem psíquica e física. Segundo Walter De Maria, o objetivo da arte é justamente fazer com que o espectador reflita sobre a relação existente entre a Terra e o Universo. Esse tipo de obra é um dos exemplos mais expressivos da filosofia da natureza, por ser uma arte que vai além daquilo que o olhar pode alcançar, provocando uma tensão entre céu e terra. Se a obra de arte deve ser apreendida através de nossos sentidos; ser capaz de provocar no espectador uma interação com ela; nela se perder; e poder ainda fazer conexões capazes de desencadear um conjunto de reflexões em direção a alguma forma, a Earth Art preenche todos esses requisitos.

A Earth Art exerceu impacto em relação à desmaterialização do objeto arte, ao romper tanto com quaisquer noções de materiais, suportes, técnicas artísticas, espaço e tempo na arte. O diálogo com a terra, através do ar, luz, vento, chuva, sol, calor, frio, tempestades, substituiu os convencionais elementos visuais e plásticos próprios da pintura e da escultura. A arte não mais representava uma paisagem, ela se tornou a própria paisagem. Assim, ao pretender abandonar os limites da galeria e do museu e partir para o espaço aberto, escala, território, repetição, processo, temas estes que a arquitetura e a arte compartilham na década de 1970, a obra de arte deixa de ocupar um lugar para ser o próprio lugar.

\section{Instalação}

Desde o início dos anos 1950, vários artistas estavam envolvidos na construção de obras, cujas características estão presentes no que passou a ser denominado de "instalação". Trata-se de trabalhos que ocupam o espaço real (em sua conexão com as condições reais, como já abordado acima) para se tornarem visuais, históricos, sociais etc. Um dos objetivos dessa arte é estabelecer uma ponte com a arte tradicional através de uma análise que apresente antigos opostos na forma de uma argumentação, como público versus privado, individual versus coletivo, cosmopolita versus vernáculo, ou seja, uma forma de desconstruir convenções tradicionais através de dicotomias.

Se o poder estético da instalação não reside no singular, no objeto comum, ordinário, mas na habilidade de se tornar parte de uma mera 
experiência contínua do real, correspondendo-se com situações específicas, há inúmeras formas de instalação, que se utilizam da luz, do som, de performances em processo, ambientes arquitetônicos construídos, e mesmo trabalhos narrativos de ordem política, vídeos etc.

Santaella (2003a, p. 145) define instalação como a "[...] ocupação de um lugar, que é tratado pelo artista como um material ou parte de um material que é incorporado ao conceito do trabalho. [...] é a arte do espaço tridimensional". Ainda considerando outros significados, essa autora salienta que:

Desde os anos 70, as instalações começaram a se fazer presentes e comparecerem cada vez com mais freqüência nas exposições contemporâneas com objetos, imagens artesanalmente produzidas, esculturas, fotos, filmes, vídeos, imagens sintéticas são misturadas numa arquitetura, com dimensões, por vezes, até mesmo urbanísticas, responsável pela criação de paisagens sígnicas que instauram uma nova ordem perceptiva e vivencial em ambientes imaginativos e críticos capazes de regenerar a sensibilidade do receptor para o mundo em que vive. (SANTAELLA, 2003a, p. 144)

Mais uma vez, Santaella (2003a) fala sobre o surgimento dessas "paisagens sígnicas", a partir das práticas visuais que ocupam espaços reais. Portanto, desde o pós-Minimalismo, sobretudo com a Process Art (Antiforma) seguida pela apropriação de espaço (ver a obra do artista Gordon Matta-Clark), a Performance, e por último a Earth Art, vamos observar uma permanente busca por espaços alternativos. Segundo Heartney (2001), a arte contemporânea está configurada na ideia de mudança e rompimento de limites. Se existe algo que une uma pluralidade de práticas visuais, este é sua relutância em não se limitar a uma simples e determinada definição. 


\title{
PERÍODO PLURALISTA: REMEMORAÇÃO
}

\author{
Articular historicamente o passado não significa conhecê-lo \\ "como ele de fato foi". Significa apropriar-se de uma reminis- \\ cência, tal como ela relampeja no momento de um perigo. \\ Walter Benjamin, 1986b
}

Inicialmente encontramos o termo "rememorar" em Andrew Benjamin (1991), ao se referir à pintura de Anselm Kiefer no sentido de retorno à paisagem, o que, segundo este autor, não se restringe apenas a uma recordação, ou a uma simples memória em que o objeto se perde efetivamente e nunca envolve a distante relação de luto. Assim, Andrew Benjamin se refere à repetição da paisagem na obra de Kiefer, dentro de 
um panorama que requer explicações mais específicas do que a simples aplicação de um termo, tanto em referência à paisagem quanto em seus sentidos etimológico e espistemológico.

O termo "rememorar" nos chamou a atenção pela aproximação com características da arte do período Pluralista (final do século XX e início do século XXI), mais especificamente quando há o retorno das técnicas e materiais tradicionais, fato que nos levou a crer que estava surgindo uma arte com algumas peculiaridades distintas. No entanto, mesmo estando em contato direto com as teorias mais recentes do final do século $X X$ e início do XXI, ainda não haviamos encontrado uma definição mais concreta.

A partir de Andrew Benjamin (1991), identificamos nas obras de Danto (1997a), e de Abigail Solomon-Godeau (1991), que a palavra after (depois) na frase que liga duas técnicas, poderia ter algum significado. Diante dessas constatações, foi possível ampliar as investigações em busca de outros autores, tendo, mais tarde, encontrado fundamentação em Walter Benjamin (2000) e Georges Didi-Huberman (2000). Assim, observemos as considerações que se seguem.

Em Walter Benjamin (2000, p. 131), o vocábulo “rememoração” aparece ao considerarmos que a arte, incluindo a literatura, tem o poder de reconstituir um tempo perdido, onde os eventos finitos são trazidos à tona; são lembranças que o artista traz para o presente para rememorar. Para ilustrar essas reflexões, Walter Benjamin destaca as obras de Proust e Baudelaire, nas quais existe uma estratégia de construção da experiência da modernidade em sua relação com a antiguidade. É essa relação com a antiguidade que Walter Benjamin (2000) chama de eingedenken, termo traduzido do alemão para o português como "rememoração": rupturas da continuidade temporal que incluem o tempo como passagem, onde o passado pode ser convocado como recordação, já que situado no presente.

Entretanto, como a arte possui uma noção de temporalidade de montagem, não é possível representar uma totalidade, trata-se de uma noção que Walter Benjamin (2000, p. 133) denomina de erfahrung e erlebinis: "lembrança e esquecimento", ou seja, a imagem ao ser apreendida não está mais no presente, mas no seu próprio devir de multiplicidade. É, portanto, 
à luz desses conceitos que se estabelece a permanente consciência do presente em sua transitoriedade. Benjamin considera que, na obra de Baudelaire, "as correspondências são os dados do rememorar. [...] não são dados históricos, mas da pré-história”, [pois, já em $A$ vida anterior, foi registrado que] "aquilo que dá grandeza e importância aos dias de festa, é o encontro com a vida anterior. [...] As imagens das grutas e das plantas, das nuvens e das ondas". Importante ressaltar que o conceito rememorar traz outros que lhe são correlatos, tais como alteridade, espaço privado, memória, nos quais a relação temporal com o passado possibilita uma experiência coletiva e de elementos que Benjamin chama de cultuais.

Aos autores já citados, acrescentamos algumas colocações importantes de Didi-Huberman (2000), nas quais esse autor também fala sobre o termo "rememoração". Para Didi-Huberman (2000, p. 9), como conceito de tempo, entende-se, também, o conceito de devir da memória, a obra como revelação dos diferentes tipos de presente, visto que "sempre, diante da imagem, estamos diante de tempos. [...] Olhá-la significa desejar, esperar, estar diante do tempo". A relação estabelecida entre tempos, memória, devir, está vinculada à teoria do olhar desse autor, que dá ênfase ao papel desenvolvido pela memória e a ela atribui camadas de tempos existentes na obra. Uma vez capacitada para dialogar com os diversos tempos, a memória vê a imagem além de uma mera imitação, mas como um intervalo traduzido de forma visível, ou seja, a linha de fratura entre as coisas. Quanto a esse diálogo, Didi-Huberman (2000, p. 242) nos informa que, para produzir uma imagem dialética, o passado deve ser convocado, e, por conseguinte, é preciso aceitar o choque de uma memória, recusando-se a se submeter ou retornar ao passado. Se o "agora” passa a ser uma valorização de um passado atualizado, o termo "rememorar", na teoria desse autor, é uma forma de atualizar o passado, uma forma constituindo-se sempre renovada ao ser instaurada e remetida a épocas anteriores.

Portanto, a fotografia, assim como a pintura, o desenho, a gravura e a escultura pluralistas, apresentados a seguir, incorporam esses conceitos de lembrança, de rememoração, com fragmentos do passado que podem ser recortes de um tempo vivido, e não necessariamente uma vida do 
início ao fim. Para tanto, a memória é evocada no momento em que lembramos de algo, trata-se de um tipo de reconstrução, e mais uma vez, novas informações vão sendo arquivadas.

Consequentemente, mesmo que, de uma maneira sutil, esse conceito, de uma certa forma, conduz o assunto deste livro à sua conclusão, ao entendermos que, através das obras analisadas, desde a última década do século $X X$ à nossa atualidade, a arte deste milênio foi se delineando com características distintas da arte dos anos 1970, e percebemos que ela toma corpo como uma forma de rememoração. Mas sendo plural, é preciso reconhecer os artistas que trabalham com essas características, visto que se trata de uma escolha do artista e não a imposição de um estilo. É algo que faz parte da obra e, por conseguinte, existe no seu interior, é desse interior que tudo emana e não de regras externas.

\section{Por que Richard Serra?}

Weight is a value for me, not that it is any more compelling than lightness, but I simply know more about weight than lightness and therefore have more to say about it, more to say about the balancing of weight, the diminishing of weight, the addition and subtraction of weight, the concentration of weight, the rigging of weight, the propping of weight, the placement of weight, the locking of weight, the psychological effect of weight, the disorientation of weight, the disequilibrium of weight, the rotation of weight, the movement of weight, the directionality of weight, the shape of weight...

Serra, 1997

Considerado como um dos escultores mais importantes da arte pósSegunda Guerra Mundial, Richard Serra está relacionado a vários movi-

\footnotetext{
1 peso tem um valor para mim, não que seja o mais compelido que ligeireza, mas eu simplesmente sei mais sobre peso do que ligeireza e, portanto, tenho mais a dizer sobre ele, mais sobre o equilíbrio do peso, a diminuição do peso, a adição e a subtração do peso, a concentração do peso, o cordame do peso, o estaquear do peso, a colocação do peso, o trancar do peso, o efeito psicológico do peso, a desorientação do peso, o desequilíbrio do peso, a rotação do peso, o movimento do peso, o direcionamento do peso, a forma do peso... (tradução nossa)
} 
mentos do final do período modernista, a exemplo do Minimalismo, mas sobretudo à Process Art (Antiforma), pela sua intensiva investigação de materiais industriais. Mas, neste caso, questionamos por que a obra de Richard Serra continua sendo importante mesmo depois que ele assume a escultura propriamente dita? E, ainda, qual a relação entre suas primeiras investigações e as monumentais esculturas mais recentes?

Richard Serra cresceu em contato com materiais industriais utilizados na construção naval, e isto pelo fato de seu pai trabalhar em um estaleiro. Portanto, esses materiais, bem como as noções de peso, massa, volume etc. sempre lhe foram familiares. Seu primeiro interesse pelo espaço e a maneira pela qual o observador se relaciona com ele vem de longa data, mais precisamente depois que Serra viu pela primeira vez a pintura de Diego Velázquez As meninas.

Desde seus primeiros trabalhos durante o final dos anos 1960, Serra e seus colegas artistas do pós-Minimalismo (Process Art), como Bruce Nauman, Eva Hesse, Robert Smithson, reagiram contra a rigidez do Minimalismo e passaram a dar ênfase ao processo e ao desempenho da matéria. Ou seja, à maneira pela qual a matéria se comporta em situações e espaços diversos. Sob a influência de dançarinos e músicos, como Yvonne Rainer, Steve Reich, Philip Glass, e sobretudo John Cage e Merce Cunningham, a matéria passa a ser vista como uma possibilidade de ser estudada também através da ação, que envolve tanto o artista, seu corpo, como o espaço.

Uma de suas obras que mais provocou intensas discussões, Verb list compilation: actions to relate to oneself [Lista dos verbos transitivos] (19671968), é um dos exemplos mais expressivos da noção de ação, pois, como os verbos transitivos, a ação "transita" ou passa do verbo para outro elemento. Conceitualmente, este trabalho de Serra consiste apenas numa lista de verbos. Através de Krauss (1998, p. 330), podemos ter uma ideia mais clara dessa obra:

Por essa razão, é sem surpresa que deparamos com uma longa lista elaborada por Serra para si mesmo em 1967-68 - uma anotação de trabalho, em cujo início se lê: rolar, vincar, dobrar, armazenar, curvar, 
encurtar, torcer, trançar, manchar, esmigalhar, aplainar, rasgar, lascar, partir, cortar, separar, soltar. Ao contemplar esse encadeamento de verbos transitivos, cada qual especificando uma ação particular a ser desenvolvida sobre um material não especificado, percebemos a distância conceitual que os separa do que normalmente esperaríamos encontrar no caderno de anotações de um escultor. Em lugar de um inventário de formas, Serra registra uma relação de atitudes comportamentais. Percebemos, contudo, que esses verbos são eles próprios, os geradores de formas artísticas: são como máquinas que, postas em funcionamento têm a capacidade de construir um trabalho. (tradução nossa)

Embora essa obra seja desprovida de material físico, paralelamente Serra deu continuidade à investigação de propriedades corpóreas dos materiais industriais e sucatas, e às inúmeras possibilidades de dar forma a esses elementos durante o processo. Contudo, não se tratava de formas fixas, mas maleáveis, a exemplo de um determinado trabalho no qual Serra atirava chumbo e aço derretido nas paredes. E assim, as formas, portanto, eram imprevisíveis. Já na obra intitulada Belts (1967), Serra utilizou tiras de borracha e tubos de néon, para experimentar a forma pura.

A partir de 1970, o aço resistente à corrosão, material associado à arquitetura e à engenharia, passou a predominar na sua criação, mantendo o mesmo interesse pelas leis da física, pela tensão do espaço, do equilíbrio e pela noção de gravidade. Com chapas de chumbo ancoradas, as novas esculturas ganharam uma escala arquitetônica, como pode ser observado nas obras Intersection II (1992-93) e Torqued ellipse IV (1999); Serra passa a desenvolver espaços com passagens, com o objetivo de permitir que o espectador possa adentrar no trabalho e experienciar seus diferentes caminhos. Com o auxílio de técnicas empregadas na fabricação de aviões a jato e navios, bem como de programas de computador - como - Computer Aided Three-Dimensional Interactive Application (CATIA) -, usado pelo arquiteto Frank Gehry, as esculturas de Richard Serra vêm sendo realizadas, sob a sua supervisão, por empresas especializadas em 
indústria naval. Ele, em pessoa, investiga a criação de suas obras, que variam em forma de elipses, algumas serpenteiam por quase 22 metros, formando quatro cavidades diferentes e apresentando paredes inclinadas, formas espiraladas conectadas, labirínticas, todas com o mesmo objetivo: proporcionar variadas sensações no observador.

Os trabalhos que mais têm despertado interesse de pesquisadores podem ser vistos em espaços como o Porto de Kaipara, na Nova Zelândia, o campus da Universidade da Califórnia, em São Francisco, em Portugal ou nos amplos ambientes do Museu Guggenheim de Bilbao, Espanha. Essas obras proporcionam ao espectador uma experiência completa, uma apreensão com todos os sentidos, pela união do visual e do mental.

Com esta proposta, Serra extrapola a técnica e se instala no espaço em que o observador pode percorrer, e tudo o mais é apenas material sólido, esticado e elástico, como nas espirais e elipses, ou denso e comprimido. Propositadamente, os tons de ferrugem alaranjados e marrom-aveludados remontam a ambientes naturais, e evocam as mesmas sensações que podem ser experienciadas frente a desfiladeiros, dunas, fendas, ravinas, montanhas, precipícios etc. Caminhar por meio das paredes curvadas provoca em muitos observadores admiração e, também, um temor atávico, algo que, segundo alguns teóricos, os poetas e pintores de século XIX devem ter sentido. Sentimentos estes que foram denominados por Kant do horror sublime que é acompanhado por uma certa melancolia, quando admiração e temor misturam-se ao prazer.

No Museu Guggenheim de Bilbao, Espanha, cujo arrojado projeto arquitetônico é de autoria do americano Frank Gehry, com fachos de luz refletindo sobre a sua fachada de placas de titânio (o edifício se confunde com uma enorme escultura), a obra de Richard Serra The matter of time está instalada permanentemente. São sete trabalhos de grandes dimensões que repercutem os entrelaçamentos e curvas sinuosas do edifício. Trata-se de um tipo de obra sem precedentes na história de escultura, visto que estas peças não são objetos que se assentam separadamente no espaço, mas estão relacionadas pela sua escala. Enormes folhas de metal oxidado se expandem, curvam-se e se entrelaçam para formar caminhos comple- 
xos e um tipo de labirinto espiralado. A cor é acidental e faz parte dos desgastes, como cicatrizes queimadas dos cilindros de aço que parecem pinturas abstratas gigantes, variando do preto e do acobreado a tons de laranja brilhante a âmbar. Lentamente, o tempo se encarregará de oxidar e tonalizar a matéria.

A obra The matter of time (2005) tem sido associada ao conceito de tempo de Thomas Stearns Eliot (1988), que em muito se aproxima da filosofia de G. I. Gurdjieff, que tem influenciado muitos pensadores e artistas. Em sua obra Four Quartets - textos publicados individualmente, de 1936 a 1942 -, Eliot (1986) demonstra seu interesse nas áreas de misticismo e filosofia. Não obstante cada um dos quatro poemas que compõem esta obra tenha seu espaço próprio, pode-se identificar neles uma estreita ligação com a natureza do tempo. Um tempo que, embora esteja voltado para a física, a teologia, é ainda um o tempo que faz parte da natureza humana. ${ }^{2}$

A experiência de uma percepção que depende do movimento e que envolve o espaço e o tempo está intimamente relacionada a processo, e busca desvelar a construção da obra para mostrar como ela foi e ainda pode ser manipulada. Uma ideia que certamente remonta aos anos 1960, época em que Richard Serra pensou a escultura não mais necessariamente como um objeto, mas como atitude, como ação, onde os materiais maleáveis podiam ser rasgados, dobrados, amassados, estirados etc. No trecho a seguir, Serra (1973 apud KRAUSS, 1997, p. 264) fala sobre uma das suas obras - Shift (1970):

O que eu quis foi a dialética entre a percepção individual do local em sua totalidade e a relação deste indivíduo com o campo percorrido. O resultado é uma forma de mensurar a si mesmo contra a indeterminação do terreno. [...] Estes degraus relacionam-se a um horizonte mutável e, como medidas, são totalmente transitivos, elevando, abaixando, estendendo, escorçando-se, contraindo, comprimindo e

2 Disponível em: 〈www.gurdjieff.org/foundation.htm〉. Acesso em: 2007. 
virando. A linha como elemento visual, por degrau, torna-se verbo transitivo. (tradução nossa)

Krauss (1997, p. 272) discute a presença de um horizonte interno e a relação transitiva deste com o mundo e com o observador, demonstrando a preocupação de Serra com o espaço físico e sua apreensão pelo espectador, uma distância que envolve o mundo visível e o invisível, a partir de cada indivíduo. Para a autora, Richard Serra traz o espectador para dentro da obra, e uma vez nesse espaço, não é possível olhar para fora, pois tudo que ele propõe é estar dentro. Serra aguça o movimento, pois “não apenas usa a forma de túnel da ponte para enquadrar a paisagem, mas também para retornar sobre si e enquadrar a si mesmo”. (tradução nossa)

\section{Do Artesanato à Arte}

A partir dos anos 1970, a arte do período pós-moderno tem sido vista como uma arte convidativa a reflexões, sobretudo quanto à posição da mulher na sociedade e como artista. No início dessa década, a arte feminista surge enfatizando materiais e técnicas artesanais, a exemplo de tecidos, rendas, bordados, patchwork, aplique, crochê, tecelagem, argila, fibras em geral, como forma de marcar a presença da mulher no cenário artístico, e, ao mesmo tempo, denunciar sua exclusão em espaços institucionalizados, como os grandes museus e galerias.

Liderada pela artista americana Judy Chicago, que constituiu um grupo de programas para mulheres na California State University-Fresno, EUA, mais tarde, juntamente à artista Miriam Schapiro, do California Institute of the Arts, a arte feminista teve um expressivo impulso internacional. A obra mais conhecida desse período The dinner party, de Judy Chicago, foi considerada, por Davies (2005), como o ícone mais poderoso da liberação e independência das mulheres, e, com isso, o uso desses materiais artesanais passou a despertar o interesse de vários pesquisadores. 
No entanto, se por um lado esses materiais têm se ampliado por artistas, independente de gênero, como Anselm Kiefer, Hélio Oiticica, Leonilson, Louise Bourgeois, Tracy Emin, vale ressaltar que, desde os anos 1970, alguns artistas ressentiram-se de maior reconhecimento, sobretudo as mulheres, pela não aceitação de obras construídas com essas técnicas. Sem normas e métodos técnicos convincentes, a crítica contemporânea em nada se opõe a questões referentes a materiais, cabe, portanto, apenas ao artista conhecer sua obra e adequá-la ao material escolhido.

Através de alguns artistas, podemos melhor explicitar as colocações expostas. Chiarelli (1996, p. 3) descreve a arte brasileira desse contexto:

Apenas em um país como o Brasil, onde a industrialização não rompeu com o modo de produção que em outras nações a antecedeu, seria pertinente encontrar artistas que, ao operar com materiais industrializados e/ou naturais (não importa), resgatam com tanta intensidade e com tamanha propriedade práticas artesanais antiqüíssimas. [...] Em vez de enrolar, vincar, torcer, cortar, esses artistas vêm costurando, bordando, ligando, colocando dobradiças entre a visualidade não-erudita brasileira e algumas das grandes questões da arte internacional das últimas décadas.

Conforme observado por Chiarelli (1996), o trabalho de Leonilson merece maior atenção, pois, seja através do desenho em forma de bordado, seja por meio da linha que ele emprega sobre tecido, sua obra é, ao mesmo tempo, os dois: desenho e bordado. $O$ interesse de Leonilson não está apenas no material pelo material, mas no que ele, como artista, tem para dizer.

Sendo uma arte assumidamente autobiográfica, onde o corpo está presente por meio de palavras, frases, imagens, formas, pequenos objetos, tecidos com padrões e texturas diversas etc., não importa se o material faz parte de uma das mais antigas prendas domésticas. Se, desde o início do processo, o artista está ciente de suas escolhas, não existe dúvida no cenário artístico quanto à sua legitimização como arte, nem qualquer confinamento a determinadas classificações excludentes. 
Voilà mon coeur (1989), de Leonilson, é uma obra composta por bordado e cristais sobre feltro, também título do texto de Pedrosa (1999, p. 21), em que este autor dá ênfase a um dos temas mais recorrentes em Leonilson, o corpo e o coração, ao afirmar que:

Talvez mais do que o corpo, o coração seja o motivo dominante e recorrente da obra. O coração como órgão muscular, bombeador de sangue através de veias e artérias; o coração como centro vital das emoções e sensibilidades do sujeito, repositório de seus sentimentos mais sinceros, profundos e íntimos. Abismos, águas, ampulhetas, âncoras, asas, átomos, crucifixos, desertos, escadas, espadas, espelhos, espirais, facas, flores, fogos, globos, homens, ilhas, labirintos, livros, mapas, matemáticos, montanhas, oceanos, olhos, órgãos, pedras, pérolas, poesias, pontes, portos, radares, relâmpagos, relógios, rios, ruínas, tempestades, templos, vulcões - tudo remete ao coração (do artista), seja atravessando-o, seja por seu intermédio, seja a partir dele.

Ao dar um destaque especial ao coração, Pedrosa, primeiramente, descreve a função desse órgão e seu significado etimológico, sem perder de vista a poética da obra. As palavras de Pedrosa chegam muito próximas da relação que o artista tinha com a sua arte. Assim, esse órgão vital está associado a emoções e sensibilidades do sujeito, seus sentimentos mais sinceros, profundos e íntimos, e nos faz pensar mais um pouco sobre a representação do corpo na nossa atualidade.

\section{Corpo está em Cena}

Santaella (2004b, p. 27) observa que, para Villaça e Góes (1998), “o corpo está em cena, sem que haja qualquer possibilidade de predizer o futuro e seus limites". Esta frase descreve em poucas palavras um dos principais aspectos das artes visuais da década de 1990, o corpo, temática que é, assim introduzida, por Santaella (2004b, p. 9): 
De certo modo, o corpo nos parece real e bem fundado. Cada um de nós é um corpo e fenomenologicamente experimentamos seus estados todos os dias [...] na dor, na fome, na excitação sexual, na fadiga e na doença. Olhamos para nós mesmos no espelho e para os outros e vemos entidades com fronteiras definidas a que chamamos de corpos.

Na passagem acima, Santaella (2004b) nos oferece uma das principais definições sobre a maneira pela qual o corpo é sentido, fornecendo uma ampla visão sobre a história do corpo, a partir de múltiplos ângulos: como ser no mundo, como construção social e cultural e suas relações desde as primeiras noções de identidade a relações simbióticas com as tecnologias, as interfaces entre corpo e cibernética, tecnologia, bioarte, moda, mídias, cultura etc.

No que se refere à representação, a história do corpo coincide com a história do homem, e por isso devemos estar atentos para perceber as diversas transformações pelas quais essas representações têm passado nas artes visuais, sobretudo a partir do século XIX, quando a pintura e a escultura se afastam de sua maior função de representação mimética.

$\mathrm{O}$ crescimento constante do interesse de artistas por esse assunto foi muito além, sobretudo "a partir das vanguardas estéticas no início do século passado, além de onipresente no decorrer do século $X X$ até hoje, o corpo foi deixando de ser uma representação, um mero conteúdo das artes". (SANTAELLA, 2004b, p. 126) Consequentemente, ele passa a ser interrogado, revisitado, nas mais diversas possibilidades de práticas visuais, que vão desde a Performance, a Body Art, passando pela fotografia, hibridizações, meios eletrônicos, às esculturas com técnicas e materiais tradicionais, em decorrência do processo de expansão do imaginário cultural, no qual se observam inquietações constantes.

Com os meios de comunicação, o homem começa a perceber, sonhar, desejar, imaginar um corpo ideal. Por outro lado, juntamente à exaltação exterior, Santaella (2004b, p. 126) explana sobre a parte interior que mostra justamente um corpo que tem sua própria identidade, seus odores, sen- 
sações etc., e a noção de um corpo meramente orgânico, anatômico e fisiológico foi perdendo espaço nas discussões intelectuais, que, de certa forma, seguem as pesquisas científicas, pelas quais cada vez mais tem sido possível analisar o corpo, através de equipamentos, de dentro para fora, em questões de segundos.

Santaella (2004b) menciona Foucault como um dos responsáveis pela abertura de um discurso mais amplo sobre esse assunto, a partir de 1960. Suas teorias interrogam sobre as relações presentes entre o corpo, o indivíduo e a vida contemporânea, sobretudo o poder que as sociedades exercem sobre ele. $\mathrm{O}$ século $\mathrm{XXI}$ abre literalmente o corpo através de minúsculos equipamentos digitais, ao tempo em que abre também o ser corpóreo e sua corporalidade, ampliando os conceitos, como a dimensão da individualidade, a forma com que o homem se mostra e se faz visto; o espaço por onde ele circula, o tempo, o lugar; estar só, estar junto, estar presente e ao mesmo tempo ausente, além do reconhecimento: "de quem é esse corpo? Masculino, feminino, homossexual, branco, de cor, idade, classe trabalhadora, classe média; o que é privado; o que é público?" (SANDLER, 1996, p. 551, tradução nossa)

Portanto, no alvorecer do século $X X I$, vislumbramos uma arte não mais rebelde, a levantar bandeiras de forma acalorada. $O$ que nos aparece como arte hoje é um universo muito amplo para poder ser classificado e dividido em "movimentos" e categorias específicas. Mesmo em se tratando de assuntos que antes instigaram discussões e polêmicas infindáveis, a exemplo do corpo da mulher, estamos diante de um período em que a arte caminha livremente, sem que haja quaisquer normas preestabelecidas. Com isto, não estamos afirmando que não haja reivindicações através da arte, o que difere é a forma como elas são passadas, ou seja, como vimos antes, nas palavras de Danto (1998), estão fora de um marco histórico, não se trata mais de algo que pudéssemos denominar de "vanguarda".

Para melhor ilustrar esse assunto, escolhemos duas artistas que trazem à reflexão esses conceitos e o retorno da escultura, com seus meios, técnicas e materiais tradicionais, hibridização, representação, desconstrução, pluralismo e, sobretudo, rememoração. O lugar onde a tecelagem, o vestuário 
e o bronze se encontram em corpo(s) que são, ao mesmo tempo, nós mesmos e um outro.

\section{Tecidos, Roupas e Bronze}

Desde os anos 1970, Krauss tem se dedicado à pesquisa de pintores, escultores e fotógrafos, com análises que examinam a interseção dos interesses de artistas com as principais correntes da cultura visual pós-guerra e aspectos como comodidade; o status do conteúdo; representação e abstração; viabilidades dos meios individuais etc. Em Bachelors, Krauss (1999) destaca a obra de nove mulheres, que reúnem aspectos quanto ao surgimento do feminismo, questionando: Que critério de avaliação pode ser aplicado à arte das mulheres? Nesse livro, ela relaciona as esculturas de partes do corpo, de Louise Bourgeois, por um viés freudiano que aborda o fetiche. Seu discurso sobre gênero descreve como a arte ocidental está repleta de discrepâncias, quando se trata da arte de artistas mulheres.

Todavia, nosso interesse não está na discussão dessas questões, nosso recorte tem uma visão mais ampla. As considerações que serão tratadas a seguir não estão embasadas nessas teorias de Krauss (1999), contudo, seu artigo nos levou a refletir sobre a escultura pluralista, com seus diversos meios de construção, e a maneira pela qual tem sido vista a presença feminina no cenário artístico internacional. Mas quanto às artistas escolhidas, por que Kiki Smith e Louise Bourgeois? Por que as duas artistas escolhidas são mulheres, se este século atual não deve excluir a arte das ditas "minorias" nem possui um estilo predominante?

Como não devemos ir além do nosso objeto investigativo, não nos distanciamos nem dos materiais nem das ideias dos artistas, estamos sempre nos reportando a todo um conjunto denominado obra. Nesse "objeto/ obra" nada se exclui, e tudo se conecta desde os primeiros insights do artista, passando pelo seu processo criativo até o seu final, visto que, como afirma Martin Heidegger (1987), a obra não existe sem o artista, e tanto um como o outro é uma mesma origem daquilo que, mais tarde construído, 
será chamado de arte. Nesse sentido, quando abordamos um tema nas artes visuais, o que aparece primeiramente é a obra, sendo assim, é da sua competência representar o que o artista pretende endereçar.

Ao iniciar este capítulo, apresentamos a migração de materiais utilizados no artesanato para as artes e o retorno da escultura tradicional. Essa transposição, um dos principais paradigmas da arte do século $\mathrm{XX}$, traz à tona a mudança de signo, de espaço, e, sobretudo, um rompimento com a constante associação desses materiais à questão de gênero. Assim, através da obra de Kiki Smith e Louise Bourgeois, alguns pontos podem ser levados em consideração. Sim, ambas as mulheres enfatizam o corpo; ambas falam sobre a condição feminina; ambas utilizam materiais que vão dos mais "nobres" aos mais ordinários; ambas retomam as características do período pluralista no qual as técnicas tradicionais voltam à cena. $O$ que nos resta refletir é sobre o lugar que elas ocupam no cenário internacional das artes, falando sempre as mesmas coisas já ditas, o que denominamos de novo e mais uma vez, ou seja, de "rememoração".

\section{Kiki Smith}

Kiki Smith é mais conhecida como escultora propriamente dita, uma das mais importantes do século XXI. Mesmo trabalhando com outras técnicas, como desenho e gravura, a escultura lhe é muito familiar, talvez por ser filha do arquiteto e escultor minimalista americano Tony Smith. Ao fazer uso de diversos materiais, a cada um deles é dado um tratamento especial e poético, seja papel artesanal, seja bronze, revelando potenciais simbólicos. Se, por um lado, a solidez do bronze significa a força duradoura da vida, por outro lado, Kiki Smith realça a fragilidade no vidro, na terracota, no papel e no gesso. Entre tecidos de musseline bordados com formas orgânicas e bonecas de pano, essa escultora vai dando forma aos interesses tradicionalmente associados à mulher e à domesticidade.

Já nos primeiros anos de sua carreira, motivada pela morte de seu pai e pela sua formação em técnica de medicina emergencial, seu tema principal evidenciava uma preocupação com a mortalidade e o corpo humano. São trabalhos que frequentemente enfocam individualmente os 
órgãos, os fluidos e os sistemas que compõem o interior do corpo, que Smith retrata em termos francos e não hierárquicos, a exemplo de trabalhos que aludem às imperfeições da pele, através do uso de papéis feitos a mão, contrastando com o volume orgânico carnudo da cera, do gesso e do metal. A obra Digestive system (1988) é uma das mais exemplares, por ser uma forma orgânica modelada em ferro fundido que dá uma ideia do sistema digestivo humano. Os considerados frágeis, também desse período, foram construídos com terracota, pedaços juntos por fios e precariamente unidos à parede. São obras que representam aspectos duais do corpo, vulnerabilidade e força, parte da condição humana.

Siri Engberg et al. (2005) explanam sobre a exposição de Kiki Smith no San Francisco Museum of Modern Art, EUA, considerando sua arte intimista, visceral e frágil, ao mesmo tempo em que apresentam uma exploração pungente do lugar da humanidade no mundo, provocando-nos a pensar, sob novas maneiras, nas condições físicas, filosóficas e sociais de nosso tempo.

A exposição, de mesmo título, desvela sua obra em ordem cronológica, dividida em três grupos de trabalhos que variam conforme os meios, com concentração em esculturas (em gesso, bronze, papel, vidro, cerâmica e outros materiais), assim como instalações, gravuras, desenhos e fotografias. A exibição abre com uma coleção de trabalhos, dos anos 1980, sobre o corpo, e continua com esculturas em grandes formatos de figuras e fragmentos até os mais recentes trabalhos, realizados em 2005. Estes últimos incluem novas temáticas, como o folclore e o mundo natural. Kiki Smith amplia cada vez mais seu vocabulário visual, ao representar figuras de tamanho natural, algumas realizadas com cera de abelha e contas de vidro. Segundo os curadores da exposição, apesar de sua explicitação, essas figuras, ao mesmo tempo em que desconcertam o espectador, parecem silenciosamente pensativas, como se tivessem esquecido o impacto que provocam, evocando um sentido particularmente comovente da humanidade. São corpos que falam sobre a AIDS, a crescente pesquisa genética e os direitos reprodutivos crescentemente controvertidos. 
Conquanto sua escultura seja virtuosa, a gravura de Kiki Smith desfruta desse mesmo mérito, o que lhe conferiu a reputação também de gravadora. Seus primeiros trabalhos nessa técnica apontam a dissecação literal e metafórica à qual o corpo humano tem sido historicamente submetido, objeto de estudo das primeiras noções no campo do conhecimento anatômico, nas pesquisas da medicina dos nossos dias atuais. A inclusão dos arquétipos femininos nas suas esculturas representa a mitologia da cultura ocidental; são imagens pesquisadas em livros, no folclore e na história da arte. Da imagem da Virgem Maria, Pietá a Chapeuzinho Vermelho, todas se tornam habitantes de corpos físicos, ao invés de abstrações da doutrina social. Alice no país das maravilhas é representada como na cena de Lewis Carroll (1980), em que Alice nada numa piscina colossal de lágrimas. Por outro lado, a escultura em bronze Lilith foi trabalhada com a ajuda de uma modelo posicionada agachada no chão, olhando agudamente sobre o seu ombro. Depois de pronta, foi exposta presa à parede, de ponta cabeça, olhando de cima, com olhos de vidro, o observador. Nela reside a força do olhar; um corpo que ocupa um lugar até então ainda não explorado pela escultura, a parede de uma galeria e/ou museu.

Outros interesses de Kiki Smith remontam à história de ritos de funerais egípcios antigos e, sobretudo, ao Wunderkammer (Cabine de curiosidades). Este último trabalho inclui plantas e espécies animais, minerais, moedas, relíquias religiosas, impressões botânicas, modelos anatômicos, partes do corpo e instrumentos médicos. A tradição de reunir tais itens desiguais sempre cativou Smith, que continuamente investiga os novos relacionamentos e possíveis significados que podem emergir quando as coisas são montadas e justapostas.

O mundo natural exerce um papel de relevância na obra de Kiki Smith. Suas paisagens podem ser tanto literais quanto metafóricas, como em muitos dos seus trabalhos baseados em animais, no cosmos e nos espaços imaginários, nos quais Smith especula se a arte figurativa deve ser representada apenas por meio de seres humanos. A série composta por esculturas que fazem menção à paisagem e aos fenômenos naturais inclui 
animais, corpos celestes, pássaros e uma variedade de lobos, veados, gatos, morcegos e camundongos carregados de associações simbólicas. São narrativas visuais sobre as conexões históricas e espirituais que realçam nosso relacionamento íntimo e frequentemente frágil com o ambiente.

Na instalação Flock (1998), composta por mil carcaças de pássaros em bronze, Kiki Smith se inspirou na Bíblia, em imagens de museus de história natural e desastres ambientais. Para essa artista, a obra é uma meditação sobre as consequências das desigualdades existentes entre os seres humanos e a natureza, e a artista frequentemente observou que seu trabalho é um esforço autobiográfico para dar sentido à sua vida e buscar o seu lugar no mundo.

\section{Louise Bourgeois}

A relação que Louise Bourgeois tem com a sua arte é de comunhão com a sua vida. Para ela, a escultura é o seu corpo, e o seu corpo é sua escultura. E por essa razão, desde o Surrealismo, o Expressionismo abstrato e até à arte feminista, Louise Bourgeois - viúva do historiador e crítico de arte americano Robert Goldwater -, tornou-se uma das escultoras mais importantes na nossa atualidade.

Stiles e Selz (1996, p. 16) apresentam essa artista:

Louise Bourgeois, originalmente trabalhou como pintora em Paris, mas agora cria esculturas em Nova lorque, criando peças em madeira. Bourgeois usou uma grande variedade de materiais, incluindo madeira, mármore, gesso, bronze, borracha e plásticos. Muitos de seus objetos enigmáticos eram autobiográficos por natureza, sexualidades femininas e masculinas é um tema importante. Em 1988, concedeu uma longa entrevista ao eminente crítico Donald Kuspit. Nos extratos apresentados aqui ela discutiu seus métodos de trabalho e interesses artísticos assim como seus pensamentos sobre feminismo. (tradução nossa)

A partir dessa entrevista, concedida a Donald Kuspit, pode-se conhecer um pouco mais sobre o processo da obra de Bourgeois (1996, p. 38-39). 
De estudos que envolvem o desenho a maquetes feitas de papelão, onde o procedimento não é um mero exercício para chegar a um fim, mas cada parte do processo é única; algumas vezes a escultura termina no estágio da madeira, outras vezes no estágio da pedra. Trata-se de um processo, que, seja na arte, seja na vida, define assertivamente sua personalidade.

Por volta dos anos 1990, por sugestão de Jerry Gorovoy (assistente da artista), toda a roupa que estava guardada desde os anos 1920 passou a ser usada e transformada em obras que deram origem a várias esculturas e a três livros artesanais. Ao rever esse vestuário e buscar nessas peças uma ideia, um propósito para uma obra, simbolicamente encontrou um imaginário que remete às noções de restauração, reconciliação, juntar as coisas frente ao medo da desintegração, que são passadas visualmente para seus trabalhos. Sabemos que os materiais estabelecem relações sígnicas, quando deslocados de contextos, a cada lugar em que eles passam a ocupar, mudando de significado, ou seja, eles, como qualquer outra coisa, necessitam de um espaço, um contexto que lhes confira um significado particular. Em arte, essa é uma tarefa das mais difíceis, pois cabe ao artista estabelecer esse diálogo em suas obras, um diálogo que envolve a ideia do artista e a matéria sensível. Na obra de Bourgeois, cada pedaço de tecido possui sua própria história, pertenceu a alguém, dividiu espaços, emoções; vestiu um corpo, ou nele um corpo se deleitou. São camadas de lembranças que só fazem sentido para a própria artista. Algumas delas pertenceram à sua família, sua mãe; um lugar específico; um tempo, uma atitude; um gesto; França; América etc. Quando um pedaço de tecido ou uma roupa aparecem separados de um corpo ou fora de um espaço da arte continuam sendo um mero retalho ou uma mera peça de vestuário. Se suas esculturas, confeccionadas com tapeçaria e tecidos, não se aproximam da passividade associada às mulheres que confeccionam mantas, cobertores etc. com esta técnica, as formas empregadas nas obras são totalmente contrárias ao sentimento de submissão, por apresentarem cabeças mutiladas e fragmentos do corpo, sobretudo quando a eles são acrescentados outros materiais como o "nobre" bronze. 
À luz de lembranças da adolescência, quando trabalhou como designer em restauração de tapeçaria antiga, na França, junto à empresa de sua família, a artista relembra momentos em que partes das peças tinham que ser redesenhadas para serem tecidas novamente. Bourgeois relembra, ainda, que, quando criança, todas as mulheres em sua casa usavam agulhas, e por elas desenvolveu uma fascinação, pelo seu poder mágico de reparar um estrago, como se fosse uma reivindicação de perdão. Em várias entrevistas sobre Bourgeois, Jerry Gorovoy, que possui intimidade com a artista e a conhece muito bem, tem falado como o tempo transforma as lembranças num tom mais doce. Trata-se do tempo exercendo seu papel de mediador, o meio ideal para traduzir os dramas pessoais sublinhados numa narrativa visual que vai aos poucos se dissolvendo.

O livro de Louise Bourgeois, Ode a l'Oubli [Ode to forgetfulness] (2004), possui páginas compostas de fragmentos de tecidos: tecidos bordados, enrolados, trançados, quilted, em camadas. São trabalhos manuais que representam as tradicionais técnicas usadas na confecção de roupas domésticas, histórias que Bourgeois não cansa de contar. Segundo ela, tudo isso fazia parte de seu universo. Com o mesmo interesse pela matéria, sem qualquer hierarquia, Louise Bourgeois utiliza bronze, tapeçaria, roupas, materiais sintéticos e industriais, dentre tantos outros, como veículos para falar sobre relacionamentos, o efeito que as pessoas provocam umas nas outras, estranhamento e intimidade, ternura, inaptidão, promessa, estados psicológicos e intelectuais, principalmente sentimentos de dor.

Bernadac e Obrist (1998) apresentam seu livro sobre Louise Bourgeois Destruction of the father, reconstruction of de father: writings and interviews, 1923-1997 [A destruição/reconstrução do pai] - com algumas informações biográficas da artista, sobretudo sobre sua relação com a escrita. Louise Bourgeois começou a escrever e a desenhar aos 12 anos de idade, e seus diários descrevem as primeiras cenas e eventos do cotidiano de sua vida familiar. Desde então, Bourgeois não mais abandonou a caneta, seja para escrever, seja para desenhar, na maioria das vezes os dois aparecem juntos, o que ela denomina de pen-thoughts. Por sua vez, a escrita é um meio de expressão controlado pela sua formação em matemática e filosofia, com 
conhecimentos de história da arte e literatura. Esse seu lado intelectual aparece em suas obras e na forma pela qual ela se expressa: reservada, porém sem segredos, sobre o tema que permeia toda a sua obra desde o início de sua carreira, o corpo. Louise Bourgeois, uma das primeiras mulheres a ter uma exposição retrospectiva no New York Museum of Modern Art, em 1982, não hesita em afirmar que sua arte é autobiográfica. 



\section{7}

A IMAGEM REVISADA

Ao voltarmos nosso olhar à fotografia já no final desta investigação, nos referimos a uma nova linguagem imagética que dialoga com outras áreas afins, contribuindo para novas maneiras de pensar a imagem, resultado do processo pelo qual a fotografia passou desde o seu advento. Tanto os movimentos modernistas de vanguarda como as estratégias contemporâneas deram origem a uma série de conceitos e teorias das mais expressivas da nossa atualidade, como apropriação de imagens, desconstrução, originalidade, origem, múltiplo, autoria do artista, aura, hibridização etc., já devidamente abordados em capítulos anteriores. Retomá-los, significa revê-los à luz de contextos mais específicos. 
Ulmer (1998, p. 85) fala sobre a desconstrução na arte e os distúrbios sociais, através do uso da fotografia e de outros meios mecânicos. A representação fotográfica, nesse sentido, é, ao mesmo tempo, uma versão realista e semiótica, e, portanto, esse tipo de representação deve ser descrito através dos princípios da colagem, ou seja, uma colagem mecânica que produz um simulacro do mundo real. Nesse ensaio, a fotografia é algo que seleciona e transfere um fragmento do continuum visual para uma nova moldura. Por ser uma reprodução mecânica, a imagem fotográfica é um decalque ou transfer, muito embora a semiótica prefira designar sua relação com o real em termos de significados icônicos e indiciais, a imagem fotográfica significa a si mesma e à outra coisa - ela se torna um significado remotivado dentro de um sistema de uma nova moldura. (tradução nossa)

Existem várias versões do argumento de que a fotografia é uma linguagem ou uma noção de montagem intelectual na qual o real é usado como elemento de discurso. Uma das versões mais relevantes da semiótica da fotografia é realizada nas estratégias da fotomontagem (na qual são unidos os princípios da fotografia e da colagem/montagem). Na fotomontagem, as imagens fotográficas são cortadas e coladas, uma justaposição provocante. A montagem não reproduz o real, mas constrói um objeto a fim de intervir no mundo, para refletir sobre a realidade. Para outros estudiosos que compartilham das teorias de Ulmer, a alegoria e a colagem parecem ser também de ordem antropológica, ou seja, a capacidade de decifrar, decodificar, ou apropriar-se, ao invés de descobrir a natureza das coisas.

Para Crimp (1980, p. 87), o objetivo desses processos desconstrutivos é desvelar o que é chamado de strata of representation, isto é, não estamos à procura de fontes nem origens, mas de estruturas de importância: embaixo de cada quadro há sempre outro quadro, os limites estéticos foram transgredidos, assim como os códigos culturais expostos. (tradução nossa)

\section{Fotografia: Espelho e Janela}

O conceito de espelhamento na fotografia vem desde a pintura de outros séculos, que se espelhavam na realidade. $O$ jogo de espelhos é também 
associado à metáfora do duplo, e muitas pessoas acreditam que o espelho reflete a verdade, sendo um símbolo de sabedoria e consciência. Essa ideia sempre existiu e pode ser encontrada nas culturas milenares, associadas a histórias sobre sua invenção, possivelmente nas águas do Mediterrâneo, aproximando-se, portanto, da mitologia grega através da relação da água e sua reflexão (nascimento, renascimento, envolvimento dos corpos), o mito de Narciso. A metáfora do espelho também se encontra no homem; o espelho de Lacan. Já em verbetes de dicionários e enciclopédias, etimologicamente, esse termo significa especulação, reflexão, pensamento. Derivada da palavra latina speculum, sidus, significa a observação dos movimentos das estrelas no céu, através de um espelho, além da informação de que o vidro tantaliza, isto é, excita o desejo de possuir o objeto, frustrando-se este desejo, continuamente, por se manter fora de alcance e podendo ser associado à maneira do suplício de Tântalo.

A janela, por sua vez emoldurada, apresenta um real limitado, nos sentidos espacial, informativo e visual, censurando o real, ao compactar, organizar e transformar informações numa visão preconcebida.

E assim é a fotografia, algo que é extraído do tempo, mas sempre se refere à outra coisa anterior, o que ela algum dia já foi. Nela reside uma marca, um rastro, um índice de um objeto que existiu. Desde as obras de alguns artistas da vanguarda modernista encontramos essa metáfora, cuja intenção de espelhar a estrutura secreta das coisas pode ser localizada no Surrealismo, na frottage do artista Max Ernst e na rayograph do fotógrafo Man Ray.

Man Ray, considerado pela crítica internacional como um dos artistas/ fotógrafos mais importantes do século XX, foi premiado com a Medalha de Ouro na Bienal de Veneza (1961) com uma fotografia que expressava a maneira como ele pesquisava certos efeitos com a luz. As formas de objetos e sombras projetadas deram origem a um tipo de técnica que ele denominou de rayographs - rayograms (fotogramas). Nesse tipo de trabalho, fotografia sem câmera, Man Ray explorava o acaso, ao colocar objetos diretamente sobre o papel fotográfico e em seguida expôlos à luz, obtendo uma imagem única e não múltiplos de um negativo, o que em muito se aproximava de suas pinturas. Membro da vanguarda modernista, esse artista atuou também como fotógrafo profissional, ao 
retratar personalidades, bem como as paisagens urbanas, sobretudo Paris, que naquela época era o centro das artes.

A partir dessas considerações, passamos a refletir sobre conceitos, como apropriação, hibridização e gênero, entre outros, na fotografia, com base no ensaio, de Solomon-Godeau (1991), a partir da exposição "Mirrors and Windows", organizada por John Szarkowski, no New York Museum of Modern Art, na cidade de Nova lorque, EUA, em 1977.

Nessa exposição, considerada um marco na história da fotografia, por ter surgido no momento efervesceste do final dos anos 1970, duzentas obras apresentadas podiam ser vistas como uma realidade exterior (janela), ou como visões interiorizadas revelatórias do inconsciente do fotógrafo (espelhos). De acordo com Solomon-Godeau, a crítica respondeu a essa mostra com opiniões diversas, o que era de se esperar, pois as obras expostas faziam parte de dois grupos: fotógrafos e artistas que utilizam a fotografia nos seus trabalhos por meio de apropriação e hibridização de imagens. Solomon-Godeau considera essa exposição um empório mais ecumênico do que as exposições anteriores desse museu, visto que a inclusão de artistas como Robert Rauschenberg, Ed Ruscha e Andy Warhol gerou polêmica sobre o uso da fotografia fora do domínio da fotografia tradicional, a fotografia considerada pura, segundo a corrente vigente do modernismo, conceito ainda preservado e guardado como relíquia no Departamento de Fotografia do Museu de Arte Moderna de Nova lorque, que sempre primou na divulgação e elevação da fotografia à categoria arte.

O que havia em comum na obra dos artistas considerados nãofotógrafos era que eles apontavam para o termo preferido por Roland Barthes déjà-lu (already-read, already-seen), como um aspecto da produção cultural, ou seja, "uma noção alternativa teorizada referente à prática artística pós-modernista, como uma mudança da produção para reprodução" (SOLOMON-GODEAU, 1991, p. 75, tradução nossa), termo também utilizado por Walter Benjamin, em $A$ obra de arte na era de sua reprodutibilidade técnica (1990) e The author as producer (1986). Nesses textos, Walter Benjamin discute a arte desses artistas que utilizam fotografias junto a outras técnicas, como sendo uma prática que em muito 
difere da estética modernista (que enfatizava a pureza), portanto, quando as fronteiras modernistas entre as formas de cultura high e low foram borradas ou obscurecidas ou escondidas. A essa mistura, surgida no seio da fotografia, Crimp (1979) define pela primeira vez como "hibridização", termo utilizado para caracterizar a mistura de meios, gêneros, objetos e materiais heterogêneos que violaram a pureza da fotografia.

Decorrente dessa exposição, Solomon-Godeau divide a fotografia, a partir desse período, em dois grupos: Fotografia de Arte e Fotografia Pós-Modernista, considerando que ambas, de uma certa maneira, estão envolvidas no mesmo processo de representação, e o que as diferencia é a intenção e o conteúdo. Se os fotógrafos que seguiram os passos de Alfred Stieglitz, Edward Weston e Walker Evans não conseguem renunciar à imagem aurática intrínseca ao campo estético e ainda estão presos às noções da estética da forma e do belo - como descreveremos mais adiante -, por outro lado, os artistas que trabalham com fotografia considerada pós-modernista estão mais centrados na imagem da cultura de massa, da propaganda, nos meios de comunicação e na correção de valores tradicionais discriminatórios.

Do final do século XX à nossa atualidade, vamos presenciar a fotografia não mais necessariamente dividida, mas como um campo aberto a inúmeras práticas que envolvem a fotografia, sem que haja uma dicotomia ou oposição. Portanto, o retorno da fotografia pura, utilizada por fotógrafos que seguiram os caminhos dos grandes mestres da fotografia do início do século $X X$, não entra em conflito com artistas que se apropriam de imagens em seu trabalho. Para melhor explanar essas considerações, já apontadas, vamos, primeiramente, ver o panorama da fotografia que se apropria e hibridiza com outras linguagens.

\section{Apropriação na Fotografia}

A fotografia atinge seu ápice com a questão da apropriação versus cópia, através da obra de Sherrie Levine, Neil, after Edward Weston. De acordo 
com Crimp (1979), a obra de Sherrie Levine causa sentimentos de desconforto, sobretudo a do filho de Edward Weston, Neil, devido às diversas questões que essa apropriação implica. Em primeiro plano, coloca-se uma interrogação: quem é essa criança? Para somente depois descobrir que essa obra não é uma foto original, argumenta Crimp.

Em entrevista à revista Arts Magazine (SIEGEL, 1985), Levine revela sua indignação com a exclusão da mulher artista, sobretudo na fotografia do cenário artístico do período moderno, que, para ela, fora predominantemente sexista. Quando questionada que a obra não era dela, afirma com veemência que a partir do momento em que suas mãos, as mãos de uma mulher, pegam na câmera, captam a imagem (mesmo que seja uma ilustração de livro), e manipulam os químicos durante o processo de revelação, a obra passa a ser de sua autoria.

Com esse discurso, Levine ilustra a ocupação da crítica pós-moderna com uma representação política e de gênero, assegurando que não se trata de uma confiscação, mas de uma apropriação. Krauss (1991), concorda com Crimp (1979) sobre a desconstrução dos mitos modernistas presentes nesse tipo de obra, ou seja, onde está presente um ato de apropriação, entendendo que a apropriação feita por Sherrie Levine não é uma coisa individual, nem única. Estudiosa de conceitos de originalidade e autoria, Krauss (1991) nos informa que a história do corpo desnudo (o nu) na arte remonta às séries dos kouroi gregos, onde o torso nu masculino passou a ser representado dentro da cultura ocidental. Os discursos de Crimp (1979) e Krauss (1991), tentando rastrear o significado das fotografias de Sherrie Levine, são similares ao discurso de Jacques Derrida (1976). Nesse tipo de representação não existe uma simples origem; o que é refletido é uma fenda nela própria; ela é tão difusa quanto reflexos em poças d'água, uma infinita referência de imagens, mas nunca uma fonte ou uma nascente. O reflexo, a imagem e o duplo se repartem em duplos, sucessivamente.

Da mesma forma que Sherrie Levine, Richard Prince, em sua série de fotografias intitulada Cowboys (1992), refotografa campanhas publicitárias do cigarro Marlboro, elevando-as à categoria arte. $\mathrm{O}$ conceito de apropriação presente na obra de Prince vai além de uma mera cópia, trata-se 
nesse caso de cópia da cópia. O interesse de Richard Prince, assim como dos artistas da sua geração que trabalham com esse tipo de conceito, não está na fotografia propriamente dita, mas no conceito da obra, trata-se de uma semelhança mais do que uma reprodução. Uma refotografia é uma apropriação de uma imagem existente, e, ao ser apropriada, tornase uma cópia de um signo já existente anteriormente. Ela é um índice de outro signo indicial, sem qualquer aproximação com o seu referente. O objeto imediato torna-se cada vez mais distante. Nessa série, suas imagens mostram a época dos cowboys heroicos do oeste americano, tema discutido por vários teóricos que associam o cowboy ao ex-presidente americano Ronald Reagan, bem como à frase política repetida pela exprimeira-dama Reagan: "just say no". Assim, Prince provoca uma crítica à noção heroica da masculinidade, à cultura de massa com as tradições do alto modernismo da cultura americana.

O estilo de vida americano passa a ser cristalizado através dos constantes diálogos irônicos estabelecidos entre o universo de artistas - como os primeiros da Pop Art - e o cotidiano, e Prince, que passou a colecionar imagens quando ainda em 1980 trabalhava na revista Time, se utiliza dessas imagens para construir seus trabalhos.

$\mathrm{Na}$ esteira de Andy Warhol, Richard Prince e Barbara Kruger são exemplos de artistas que migraram da área da publicidade, e, para eles, a linguagem dos meios de comunicação lhes era familiar.

Atuante no âmbito de gênero, Barbara Kruger investiga a influência dos signos na sociedade, sobretudo as imagens da mulher. Suas obras são consideradas desconstrutivistas, pelo fato dela trabalhar a partir de anúncios publicitários, cortando palavras e imagens e rearrumando-as, depois, sob outro conceito, mas utilizando-se dos mesmos meios de publicidade considerados por ela sexista, pois a mulher é um mero objeto. As teses de Freud e Lacan eram utilizadas por este movimento feminista para explicar a mulher como um ser passivo. Barbara Kruger dá ênfase em sua obra aos conceitos de consumismo, meios de comunicação de massa, violência doméstica, objetificação, desumanização, problemas sociais próprios do mundo contemporâneo. Kruger afirma que seu objetivo é provocar ques- 
tões sobre o poder e seus efeitos em nossa condição humana, e como ele é construído, mostrado, usado e abusado, questionando: por que somos apenas espectadores e consumidores passivos desta cultura de massa?

Durante as comunicações interpessoais diárias do sujeito, as representações sociais contemporâneas funcionam na comunidade como práticas convencionais que se tornam, com o passar do tempo, algo real, ou seja, contribuem para dar vida a ideias até então desconfiguradas. Assim, a constante afirmação de relação de um determinado conceito a um objeto ou pessoa, passa a fazer parte da constituição daquele grupo. $O$ termo "desumanização" trata, de uma certa forma, daquilo que provoca a objetificação, inferioriza, torna-se um preconceito de todas as ordens possíveis, como racial, de gênero, dentre tantos outros. O termo "objetificação" tem sido usado amplamente por "artistas feministas", cujas obras trazem esse aspecto desconstrutivista.

A objetificação do corpo é um dos preconceitos mais conhecidos, e é, na maioria das vezes, como uma resposta a esse tipo de objetificação que os artistas desconstrutivistas, do final do século $X X$ e início do século $X X I$, vêm trabalhando através da fotografia. Vale ressaltar que existe uma diferença entre o que é denominado de "artista desconstrutivista" e o termo "desconstrução". "Artista desconstrutivista" é um termo que vem sendo aplicado aos artistas da geração, emergente nos anos 1990, e que vêm trabalhando com questões, em sua maioria, referentes a gênero, mas não necessariamente, artistas feministas. Dizemos não necessariamente, visto que outros artistas, como Richard Prince, podem ser considerados desconstrutivistas. O que eles fazem?

Nesse cenário, Sherrie Levine, Cindy Sherman e Barbara Kruger, consideradas não-fotógrafas no sentido convencional do termo, pelos críticos e historiadores, apontam para uma hibridização conceitual da fotografia e da performance - fundamentalmente desenvolvida em torno do conceito/ problema da identidade; enquanto algo que não é uma emanação natural do indivíduo, mas uma construção derivada da interação entre o indivíduo e aqueles que o rodeiam. São obras que criticam o comportamento do mun- 
do moderno, em que pensamentos, atitudes e desejos são determinados por convenções sociais e pelos meios estereotipados da cultura de massa, sob a influência de autores como Michel Foucault, Roland Barthes, Julia Kristeva e Jacques Lacan. Barbara Kruger concebe um sujeito construído pelas forças sociais, pelas redes de relações - pela posição dos sujeitos frente aos outros - que definem o indivíduo. Em suas obras, ela entende que o poder se impõe através da imagem e o panorama das relações sociais é visto através das imagens.

Os depoimentos do artista Sol LeWitt (1967), caracterizam a arte conceitual como algo que nos faz refletir sobre obras consideradas desmaterializadas, que contestavam o conceito tradicional de autoria, ao tempo em que cortejavam a efemeridade ou a imaterialidade.

Para Owens (1998, p. 75), as diferentes personalidades performadas por Cindy Sherman forçam o espectador, a um só tempo, a identificar um mesmo modelo (a própria artista) "e ao mesmo tempo reconhecer um tremor ao redor das bordas dessa identidade". (tradução nossa) Cindy Sherman se inscreve no âmbito dos conceitos contemporâneos, ao recusar colocar a noção de uma identidade autêntica, a individualidade em uma única posição, substituindo essa posição por identidades múltiplas, que são, em sua maioria, imagens que imitam o cotidiano de famílias; gestos; atitudes; modos de se vestir; comportamento por meio de olhares - ingênuos e sedutores -, que se resumem em máscaras, disfarces.

Krauss (1993) revela que a obra dessa artista é como um composto de todas as coisas que ela já fez. O composto faz parte desse período em que a noção de identidade é um jogo de identidades autênticas num estado de crise, em constante devir de estruturas imaginárias. Na tradição ocidental, o corpo, bem como identidades sexuais, são representadas e pensadas de uma maneira dicotômica. De acordo com Cindy Sherman, a base de sua obra é justamente uma crítica a dicotomias, tais como conceitos opostos: homem versus mulher, assunto versus objeto, ativo versus passivo, nos quais, segundo essa artista, a mulher sempre ocupa o espaço negativo. 


\section{A Fotografia depois da Fotografia}

Entre as cidades invisíveis há uma sobre palafitas, e os moradores observam do alto a própria ausência. Talvez, para compreender quem sou, eu tenha que observar um ponto no qual poderia estar, e não estou. Como um velho fotógrafo que faz pose diante da objetiva e depois corre para acionar o botão do disparador à distância, fotografando o ponto em que poderia estar, mas não está. Nos momentos de euforia, penso que aquele vazio que não ocupo pode ser preenchido por outro eu mesmo, que faz as coisas que eu deveria ter feito, e não soube fazer. Um eu mesmo que só pode brotar desse vazio.

Ítalo Calvino, 2006

Fotografia depois da Fotografia [Photografy after photography] (SOLOMON-GODEAU, 1991) é um texto introdutório que apresenta alguns artistas que vêm trabalhando com a fotografia, a partir de diferentes meios e conceitos para serem refletidos à luz de teorias contemporâneas. Um desses conceitos é auralidade, amplamente discutido pelo filósofo alemão Walter Benjamin no texto já considerado clássico: $A$ obra de arte na época de sua reprodutibilidade técnica (1990).

Walter Benjamin (1990) analisa a aura como uma singularidade; algo que não pode ser repetido; uma qualidade de transcendência; uma figura singular composta de elementos espaciais e temporais; a aparição única de uma coisa distante, por mais perto que ela esteja. Além de unicidade e distância, a aura é atinente a uma capacidade humana que consiste na satisfação da expectativa contida em cada olhar: a de ser correspondido. Conforme explica esse autor (1990, p. 139-140):

Está implícita no olhar a expectativa de ser correspondido por aquilo a que se oferece. Se tal expectativa (que pode associar-se no pensamento tanto a um olhar intencional de atenção como a um olhar no sentido literal da palavra) é satisfeita, o olhar consegue na sua plenitude a experiência da aura. [...] A experiência da aura repousa, portanto, na transferência de uma forma de reação normal na so- 
ciedade humana para a relação do inanimado e da natureza com o homem. Quem é olhado ou se julga olhado levanta os olhos.

Para Benjamin (1990, p. 140), "perceber a aura de uma coisa significa investi-la do poder de revidar o olhar". Mas por que esse conceito passou por todo o século XX e continua fazendo parte das discussões sobre a arte? Sem a intenção de esgotar a questão, trata-se de uma característica do período em que vivemos.

Quando analisamos o efeito causado pelo advento da fotografia, vamos observar a presença de conceitos, como aura, originalidade, múltiplo e, sobretudo, a aderência da imagem ao referente, o instante captado. Recapitulando as considerações de Santaella e Nöth (1997, p. 165), as pinturas são irreprodutíveis. Esses autores consideram tais imagens como fruto de um instante no qual o pintor pousou seu olhar sobre o mundo, dando forma a esse olhar num gesto irrepetivel. Já a imagem fotográfica traz o "enfrentamento entre o olho do sujeito, que se prolonga no olho da câmera, e o real a ser capturado". Se todos esses conceitos já foram discutidos incalculavelmente, inclusive o termo "depois", o que significa a fotografia depois da fotografia? Ponderemos, portanto.

Para Abigail Solomon-Godeau (1991, p. 85), "a idéia de fotografia depois da arte da fotografia aparece como uma extensão ao invés de um campo encolhido", o que em muito se aproxima do conceito de "campo expandido" de Rosalind Krauss, ou seja, um campo sem limites onde o artista pode trabalhar fora da pureza de uma determinada técnica ou através de seus próprios meios tradicionais.

Assim, uma das mudanças ocorridas na fotografia, e que afeta sua característica indicial, se dá com a fotografia digital, cujo processo é característico da fotomontagem dadaísta, de 1929. Como nos informa Danto (2001a), a possibilidade de cortar, organizar e colar imagens fotográficas, numa justaposição evocativa, retorna, oferecendo ao artista condições para construir imagens a partir da seleção de várias fotografias e desse próprio processo. A diferença é que dessa vez, a tesoura e a cola são substituídas pelo computador e programas específicos. Mas, voltando às 
considerações de Santaella e Nöth (1997), nesse processo pode ocorrer a quebra dos princípios indiciais da fotografia, visto que as mesmas estão sujeitas a diversas possibilidades de manipulação, modelação e edição de imagens. A fotografia, por conseguinte, pode representar mundos diferentes, próprios da criação do artista. Ainda de acordo com esses autores, a fotografia faz um jogo entre realidade - o seu referente, o real - e o imaginário. A partir do momento em que o real é transformado em imagem, ele desaparece sob uma condição de tempo que transforma tudo e todos em frações de segundo. $O$ presente, o agora, é um processo contínuo de devir, já se tornando futuro.

No ensaio The reconfigured eye: visual truth in the post-photographic era, William J. Mitchell, (1994), encontramos uma passagem em que esse autor faz uma abordagem sobre a fotografia tradicional e a fotografia digital, ao narrar um episódio que envolve os governos da Líbia e dos Estados Unidos, quando a fotografia foi motivo de discussão, ao ser usada como prova. Mesmo admitindo que o diálogo sobre a veracidade dos fatos através de imagens é muito pequeno diante de tragédias, não deixa de ser um exemplo para conceituar a fotografia na era digital. Nesse contexto, Mitchell cita Susan Sontag, quando esta observa que "a fotografia passa por uma prova indisputável de que uma certa coisa aconteceu”. (SONTAG apud MITCHELL, 1994, p. 23, tradução nossa) Esta colocação é de algum modo, hoje em dia, tecnicamente improvável, visto que qualquer pessoa, com acesso a algumas imagens de aeronave, um artifício de captura de imagem e um computador pessoal com software de equalização gráfica, poderia produzir este tipo de imagem em alguns minutos.

Essa fundamental (embora ocorram outras) característica da fotografia - a de registrar um evento - torna-se abalada pelo surgimento da imagem digital. De uma maneira ou de outra, uma fotografia fornece evidência sobre uma cena. De acordo com Susan Sontag, a fotografia não é apenas uma imagem - como a pintura é uma imagem -, uma interpretação do real; é também um vestígio, algo diretamente traçado fora do real, como uma pegada. (SONTAG apud MITCHELL, 1994, p. 23, tradução nossa) 
Roland Barthes (1980, p. 16), introduz outra metáfora: da vidraça e da paisagem, e reivindica que o referente adere. Por todas estas razões, argumenta Mitchell (1994), não obstante necessariamente coerentes, a câmera comumente foi vista como um artifício a ser usado na observação de coisas para registrar vestígios supremamente exatos dos objetos diante dela, como se fosse um super-olho, uma prótese perceptiva que pode parar a ação melhor do que o olho humano, dar melhor resolução de detalhe e que não deixa de registrar nada que o campo de visão possa alcançar. Por isso é que seu conceito está na noção de ligação da imagem a um referente, como se este estivesse colado a ela. Mitchell (1994) é enfático ao sublinhar que a fotografia digital quebra com o fato puramente causal e insere a possibilidade de um envolvimento com o ato intencional, que se aproxima do processo pictórico, a partir da ampla variedade representacional de pinturas, visto que o pintor não tem que aceitar a relação causal entre uma descrição e o objeto a que ela se refere. Muitos mestres da fotografia do início do século $X X$ já consideravam importante a manipulação de exposição e variáveis de foco como meios importantes de apreender suas intenções. E algumas práticas fotográficas e ações, como ampliação, corte e impressão, tornaram-se experimentos essenciais. As duas distinções feitas por Mitchell (1994), ou seja, a distinção entre componentes intencionais e causais existentes nos processos de produção de imagem devem ser pensadas no espectro que percorre as condições não-numéricas e numéricas. A imagem não-numérica, que é o produto de muitas ações intencionais, não estabelece a existência do objeto retratado (caso esse objeto exista), muito menos fornece muita evidência de confiança sobre ele, mas revela muito sobre o que estava na mente do artista. Já uma imagem numérica, a qual é, até certo ponto, automaticamente construída através de algum tipo de dado sobre o objeto, envolve pouco ou quase nenhum ato intencional, proporcionando muito menos informação sobre o artista, mas fornecendo uma evidência mais fidedigna do que estava lá fora, à frente do sistema de produção da imagem.

Diferentemente, a fotografia digital traz consigo possibilidades de trabalho que podem alterar totalmente a imagem, modificando conceitos 
preestabelecidos sobre a fotografia tradicional. Os artifícios são muitos, mas nesse caso é necessário que haja uma educação ética, sobretudo em fotografias que possuem funções determinadas. Essas devem registrar a realidade dos fatos. E neste estudo estamos nos referindo apenas à imagem artística, mais especificamente ao processo de construção de poéticas digitais. A distinção entre o processo causal da câmera e o processo intencional do artista não possui a mesma força da narrativa tradicional de origem. A imagem perde seu poder de convencimento, pois o referente veio descolado.

Nesse influente ensaio, Mitchell (1994) aborda, além dos conceitos já mencionados, o conceito de coerência, que aponta para a possibilidade de se apreender uma fotografia indo além dos meios de prova de uma certa imagem como sendo o registro verdadeiro de uma cena ou de um acontecimento real. Ao ampliar essa possibilidade, o espectador pode optar por tomar uma posição contrária e tentar demonstrar que o registro não é necessariamente verdadeiro. Desse modo, a imagem proporciona um jogo estético, a partir de suas inconsistências, e nesse jogo deve haver uma análise, com algum tipo de teoria de coerência, ao invés de uma teoria de verdade como correspondência.

Todas as teorias já expostas nos levam a entender a profusão de meios existentes para se trabalhar com a imagem. A fotografia pluralista retoma técnicas de outros períodos e nos faz ver que, apesar dos avanços tecnológicos, o retorno da aura em obras de fotógrafos e artistas é um dos exemplos da relação do homem com o mundo tecnológico. Se, por um lado, ele acompanha esses avanços, por outro, ele busca o passado para rememorar eventos que fazem parte da história da humanidade.

\section{Andreas Gursky}

O fotógrafo alemão Andreas Gursky, que desde cedo se interessou por fotografia, por influência de seu pai, fotógrafo comercial, estudou em Folkwangschule, em Essen, Escola de Fotografia tradicional, fundada por Otto Steinert, na Alemanha Ocidental, e mais tarde, com Bernd Becher, 
na Kunstakademie, em Düsseldorf. Considerado um dos mais importantes fotógrafos do início deste século, desde 1992 ele recorre à manipulação digital de modo a realçar os elementos formais que irão valorizar a imagem ou, por exemplo, para aplicar um conceito de imagem que, em termos de perspectiva real, seria impossível realizar.

Devido ao formato de suas fotografias, que fogem à dimensão tradicional, bem como pelas cores e temas abordados, sua fotografia é considerada monumental e, à primeira vista, sua obra se assemelha a uma pintura impressionista, na qual, à distância, os objetos se apresentam como pontos de cores, uma obra que propõe uma contemplação demorada, seja pela suas proporções, seja pela abstração da imagem.

Como herdeira da fotografia pura, onde a técnica é virtuosa, Gursky retoma o sublime na paisagem, mas não retrata a natureza de Schelling, no sentido dos campos do século XVIII, dando lugar a um outro tipo de paisagem, a da era da tecnologia digital, em que multidões de pessoas ocupam espaços nos grandes centros. Seus temas são essa monumentalidade, adquirida através de uma ampliação manipulada pelos recursos tecnológicos e digitais, próprios da sociedade pós-industrial. A vida urbana, o mundo do consumo; espaços com pessoas em movimento; comportamentos sociais, referências da cultura de massa e da mídia, muitas vezes relacionadas a uma noção de natureza mais ampla, ou seja, à natureza das coisas em geral e ao estado existencial das coisas. Esse conceito pode ser entendido através de suas obras, a exemplo de bolsas de valores do mundo contemporâneo, lojas de produtos a US\$1,99, prateleiras de grandes magazines e supermercados repletas de produtos, locais em que ele busca representar o que considera "de-individualized", isto é, o indivíduo não é importante, mas a espécie humana e seu ambiente em um tipo de investigação sociológica desromantizada. A imagem reduz a humanidade à sua expressão maquínica, parte da economia global avassaladora em que, invariavelmente, se inserem os indivíduos, tanto na sua expressão laboral como no lazer, conduzindo-os assim a uma presença diminuta, quase microscópica, como se o objetivo fosse desindividualizá-los. 


\section{Spencer Tunick}

O americano Spencer Tunick é conhecido por fotografar multidões de corpos nus em espaços e lugares, por todo o mundo. Seja através de nacionalidade, sexo, gênero, raça, idade, todos se igualam na obra desse fotógrafo. O que nos chama atenção é a maneira pela qual Tunick arruma o cenário a ser fotografado. Mas, na verdade, o que esse fotógrafo faz são instalações efêmeras, ao mesmo tempo instalação e fotografia, em espaços ao ar livre ou fechados, públicos e privados, institucionalizados (galerias e museus), parques, rodovias, pontes, construções, edifícios, praias, vales, montanhas, jardins etc. Ao confrontar espaços urbanos com amontoados de pessoas nuas, Tunick ressalta várias noções, como o corpo, o espaço, um lugar, vida, liberdade, sensualidade.

Seu trabalho iniciou-se, já no final da década de 1990, quando fotografou nus em lugares públicos na cidade de Nova lorque, onde ele reside. Aos poucos, sua obra toma uma outra dimensão, de imagens intimistas para instalações grandiosas e ganha um caráter de celebração, um evento vivo, ao considerar as sete mil pessoas que foram agrupadas por esse fotógrafo em Barcelona, em 2003. Mais tarde, em 2007, uma de suas obras mais recentes bateu um recorde, 18 mil nus posaram numa das principais praças da Cidade do México, a Plaza de la Constitución. Ainda em 2007, Spencer Tunick também foi contratado pela Dream Amsterdam Foundation para realizar um projeto, parte do evento artístico Dream Amsterdam, que foi realizado em um campo de tulipas, em Schermerhorn. Outros ambientes também foram utilizados, nesse projeto, como estacionamentos de carros e vias públicas, em que mulheres andavam de bicicleta. Uma instalação menor foi realizada sobre uma plataforma que dava a ideia de que os corpos flutuavam sobre as águas. Todos esses lugares são ícones da nação holandesa e representam a geografia e a cultura desse país.

Algumas obras são intencionalmente políticas, como a realizada com a colaboração do Greenpeace, a qual visava chamar a atenção sobre fenômenos que atingem a Terra, ecologia etc. Nessa instalação, os participantes voluntários colaboraram para dizer ao mundo sobre o grave problema do aquecimento global que afeta muitas áreas, sobretudo o 
descongelamento das geleiras suíças. Já na Bélgica, país conhecido pelo chocolate, Tunick cobriu homens com chocolate branco líquido e mulheres com chocolate preto. Relevante ressaltar que sua arte segue uma regra composional através de estudos sobre os espaços que elas vão ocupar e os corpos que dão formas diversas. Isto é, algumas fotos destacam a linha do horizonte, outras são agrupamentos enfileirados, e em diversos sentidos, vertical, horizontal, a triangulação, bem como outras formas geométricas nas quais ele explora a perspectiva. Sua obra realça a harmonia entre o homem e a natureza, através de uma semiótica que ressalta todos os signos que ele pode abordar.

\section{Atta Kim}

Assim como Tunick, o fotógrafo sul-coreano Atta Kim trabalha com o corpo humano, explorando fotografia a cores em grande formato. Sua obra também são instalações fotografadas, onde corpos são pendurados, amassados, comprimidos através de placas de acrílico e pessoas confinadas em caixas transparentes. Atta Kim conceitua sua obra por meio de forte influência na iconografia zen-budista, na existência temporal, nos escritos de Heidegger e de G. I. Gurdjieff, na questão transcendental.

O Projeto museu (1995-2002), sua primeira série em cor, retrata pessoas ou grupo de pessoas dentro de caixas transparentes como se fossem artefatos de museus, e endereça questões sobre a função dessa instituição, como catalogar, classificar, categorizar, preservar, conservar, colecionar etc. Para Kim, esse projeto é seu próprio museu, onde as pessoas são preservadas como tesouros contemporâneos.

Outras séries apresentam homens e mulheres nus, também colocados em caixas transparentes, em ambientes abertos, como parques, praias, florestas, bem como no centro de cidades. Seu tema aborda o homem frente a situações como a guerra, o holocausto, com corpos comprimidos por placas de acrílico e pendurados por ganchos como se fossem carnes expostas; soldados coreanos feridos e despidos, exibindo suas feridas por cicatrizes expostas ou membros amputados, ou por acessórios necessários por sua enfermidade tal como muletas ou cadeiras de rodas. Dentro de 
vários contextos, na série Nirvana (2001), Atta Kim obteve permissão para fotografar corpos desnudos no Templo Budista, em razão da sua justificativa: "to see the purity".

\section{Misha Gordin}

Em seu livro Hidden: the conceptual photography of Misha Gordin (2007), este fotógrafo apresenta sua obra junto à sua autobiografia. De uma forma peculiar relata, paulatinamente, em frases curtas, passagens de sua vida, desde a infância, onde a fotografia está presente. Nascido no primeiro ano depois da Segunda Guerra Mundial, seus pais somente sobreviveram às adversidades de evacuação, retornando a Riga, agora sob ocupação soviética. Gordin frequentou a faculdade de engenharia aeronáutica, mas optou desde cedo pela imagem, ao trabalhar no Riga Motion Studios, como desenhista de equipamentos para efeitos especiais. Sem conhecimento sobre a arte, devido à situação política, poucas informações sobre a arte ocidental estavam disponíveis. Amante da literatura, Gordin dedicou-se à leitura de Dostoevsky, Bulgakov e à cinematografia de Tarkovsky e Parajanov, mas sempre em busca de uma maneira de expressar seus sentimentos e pensamentos pessoais através da fotografia. Após algum tempo perseguindo o caminho da fotografia conceitual, em 1972 criou sua primeira e mais importante imagem: Confissão. Essa obra tornou-se a espinha dorsal do trabalho que vem produzindo nas últimas duas décadas.

Já nos Estados Unidos, em 1974, esse fotógrafo aproximou a fotografia à permanente questão: Aponto minha câmera para fora do mundo existente ou viro-a em direção à minha alma? Estou fazendo fotografias da realidade existente ou criando meu próprio mundo, tão real, mas não existente? Para ele, que coloca esta arte no mesmo nível da pintura, da poesia, da música e da escultura, a fotografia conceitual é a forma mais elevada de expressão artística. Gordin explora sua visão intuitiva e busca conceitos pessoais na linguagem dessa arte, para refletir sobre as possíveis respostas às questões mais importantes do ser, como: nascimento, morte e vida. Ao considerar que criar uma ideia e transformá-la em realidade é um processo essencial da fotografia conceitual, não segue os caminhos 
das novas tecnologias. Não obstante a facilidade de produzir imagens ter mudado o modo tradicional de ver o mundo através das lentes, desfrutar de paisagens, o mistério do laboratório escuro, tudo isso muda em todos os seus significados, símbolos e mistérios. Esse fotógrafo acredita que um conceito pobre, perfeitamente executado, ainda faz uma fotografia pobre. Portanto, o ingrediente mais importante da imagem poderosa é o conceito. A mistura do talento para criar um conceito e a habilidade de saber expressá-lo são os dois aspectos mais importantes para se criar uma fotografia conceitual convincente. A manipulação de imagens fotográficas não é uma ideia nova. Aliás, até certo ponto, todas as imagens são manipuladas. O poder real da fotografia emerge quando a realidade alterada é apresentada como existente, ou seja, é esperado que algo seja percebido como tal. Uma imagem obviamente manipulada é uma fraude que mostra uma falta de entendimento do raro poder da fotografia - a crença gravada em nosso subconsciente de que aquilo que foi capturado pela câmera tem que existir. Nos melhores exemplos de imagens manipuladas com êxito, sempre haverá a pergunta: "isto é real?"

Misha Gordin (2007) fala de suas primeiras lembranças, sua infância e seu despertar para o mundo; a vida depois da guerra; do esconderijo nas ruínas dos edifícios bombardeados; o homem sem pernas empurrando à sua maneira um pequeno objeto; lembra de quando brincava sozinho e com outras crianças; eles faziam seus próprios brinquedos. Ao descrever a natureza, fala das águas frias do mar Báltico; de ocasos e das silhuetas silenciosas ao longo do contorno da costa; de florestas plenas de segredos; dos peixes à venda no mercado; de flores que colocavam no monumento de Lênin; de momentos amorosos; de um arco-íris a mergulhar num lago próximo de sua casa, onde vive hoje. Diz que ao retornar para a casa da floresta, traz consigo o aroma de uma fogueira, e à noite escuta chamados misteriosos de uma coruja e, assim, sente que está em plena sintonia com a natureza. Gordin (2007) descreve as estações do ano, as quais ele vive intensamente, desde o inverno, com a neve, ao retorno dos pássaros, na primavera. Para ele, os verões estão plenos de energia criativa, e esta maneira de viver é o seu processo criativo. Busca fotografar sonhos, e o 
processo inicial para ele é semelhante a escrever poemas. Quanto à parte técnica, Gordin (2007) prefere não descrevê-la, pois acredita que com isso diminui o poder da imagem. Mas todos sabem o quanto a técnica é especial para esse fotógrafo, e quanto ele valoriza o processo puramente artesanal, sem quaisquer efeitos que fujam da sua tradição. Misha Gordin é um dos raros exemplos de um fotógrafo que vive a fotografia em comunhão com a natureza, e a essa arte é sempre fiel. (tradução nossa)

\section{A humanização da máquina e o pensamento oriental}

Uma das maiores preocupações no final de século XXe início deste milênio é sobre que tipo de mundo e de realidade o artista pode expressar. Após a invenção de um enorme aparato tecnológico da imagem, fixa ou em movimento, seja na arte ou na ciência, a espiritualidade, o conceitual e a percepção são preocupações de artistas que trabalham com a arte tecnológica, em que o uso de equipamentos de primeira geração não ofusca os temas por muitos deles explorados, como ancestralidade, solidão, medo, multidão, sonhos e universo onírico, desespero, esperança, fascínio, repulsa, sofrimento etc. Podemos ilustrar esses conceitos nas obras de Roy Ascott, Nam June Paik e Bill Viola, já que eles trabalham com o objetivo de humanizar a tecnologia.

Ascott (1996, p. 491-492) nos informa que a década de 1980 presenciou as duas mais poderosas tecnologias, da computação e das telecomunicações, convergindo para o mesmo campo de operações, e resultando na junção de outras mídias eletrônicas, incluindo vídeo, sound synthesis, remote sensing e uma variedade de sistemas cibernéticos. Esses fenômenos estão causando uma grande influência no comportamento da sociedade e dos indivíduos, levantando questões importantes, referentes ao que é ser humano, ser criativo, pensar e perceber, e questionando, enfim, nosso relacionamento com o outro e com o planeta como um todo. A cultura telemática consiste num conjunto de comportamentos, ideias, valores e objetivos que são totalmente diferentes daqueles que haviam 
formado a sociedade, desde o lluminismo. Novos paradigmas surgiram, novas metáforas culturais e científicas têm sido criadas, novos modelos e representações da realidade estão sendo inventados, novos significados expressivos têm sido manufaturados. Para Ascott (1996), nada na arte interativa é fixo, nada é estável; a mente do homem está se expandindo cada vez mais e essa noção de expansão se dá entre mente, computador e ambiente. (tradução nossa)

Em Consciousness reframed: art and consciousness in the post-biological era, Roy Ascott (1997) explicita que a arte interativa designa um amplo espectro de práticas visuais que utilizam diversos meios, como performances e experiências individuais em um fluxo de dados: imagens, textos, sons, ainda com diversas estruturas, ambientes ou redes cibernéticas adaptáveis e inteligentes de alguma forma, de tal maneira que o espectador possa agir sobre o fluxo, modificar a estrutura, interagir com o ambiente, percorrer a rede, participando, assim, dos atos de transformação e criação.

Se as estéticas da arte tecnológica estão ligadas aos conceitos e práticas da interação, da simulação e da inteligência artificial, Ascott (1997) faz estudos comparativos bastante significativos entre a arte tradicional, à qual ele sempre se refere como arte clássica, e a arte tecnológica, mais especificamente a arte interativa. Para Ascott (1997), a arte que ele denomina de tradicional está preocupada com a ideia de um mundo real; trabalha com a expressão; dá ênfase à aparência das coisas; prioriza as representações. $\mathrm{O}$ espaço euclidiano trabalha com a estabilidade, e o artista em isolamento, solidão. Por sua vez, a arte interativa traz novos processos de percepção e comunicação; informação e cognição. Isso significa que, enquanto as linguagens tradicionais estão preocupadas com a expressão, a arte interativa está interessada na interação. Apontadas por Ascott (1997), essas diferenças mostram um mundo instável, em que a questão primordial aponta para que tipo de mundo e de realidade o artista pode se expressar.

Outra linguagem contemporânea, que teve um grande impacto e desenvolvimento no final do século passado e início deste, é a Videoarte, que surge em 1965, quando o artista coreano, integrante do Fluxus, Nam 
June Paik, fez suas primeiras fitas com uma, então recente, câmera portátil sony e as apresentou algumas horas depois no espaço denominado Café a GoGo, no Greenwich Village, em Nova lorque. Considerado o pai da Videoarte, Paik iniciou suas investigações em música e em filosofia, e explorou várias maneiras de integrar arte e vídeo. Junto a John Cage e Karlheim Stckhausen, interessou-se pela música em todos os seus aspectos. Com Charlotte Moorman, Paik extrapolou conceitos como espontaneidade, perigo, imprevisibilidade e erotismo nas suas performances. Seu objetivo era humanizar a tecnologia assim como renovar a forma ontológica da música.

Já no trabalho de Bill Viola, vamos encontrar a presença da alta tecnologia, do homem, do progresso, e da incansável busca pelo invisível, pelo espiritual. No final da década de 1990 e início do ano 2000, Viola mostra que a arte sempre dependerá de dois fatores importantes, que cada vez se afastam e paradoxalmente se aproximam. Um é o tempo em que o artista vive e o outro é sua origem enquanto ser humano. Por isso, enquanto o primitivo se aproxima cada vez mais de nós, o nosso presente aceleradamente se afasta. No início do catálogo de sua exposição "Bill Viola - a 25-year Survey”, no San Francisco Museum of Modern Art, em 1999, a frase de Bill Viola - "É preciso apenas um instante para que uma impressão se torne visível" -, reporta-se a uma das principais características da imagem, do real e da sua representação. Nesse catálogo, Ross (1999, p. 2,) apresenta o trabalho de Viola, com as seguintes palavras:

Esses vinte e cinco anos de investigação consistem em instalações, videotapes, notas e desenhos de trabalho (do processo) desse artista. Chegou o momento em que muitos querem saber os meios pelos quais a arte e as novas tecnologias interagem. Embora Viola use nas suas instalações equipamentos de vídeo e computador altamente sofisticados, de alta tecnologia, os temas por ele explorados são antigos e, ao mesmo tempo, universais. A beleza simples, o impacto visceral, a eterna espiritualidade atemporal do seu trabalho nos sensibiliza profundamente. [...] Seu trabalho está embasado num conjunto de valores espirituais, os quais têm influenciado profundamente, e continua pro- 
porcionando seu desenvolvimento zen-budista, o misticismo cristão, a ótica física, os mecanismos da percepção e a poesia lírica Islâmica dos mestres Sufi. Sua arte alcança as origens do conhecimento que reside no âmbito da experiência cotidiana. (tradução nossa)

E citando Kabir, Ross termina a apresentação: Wherever you are is the entry point - Kabir (1440-1518). ' Se pensarmos em que tipo de mundo e de realidade o artista pode se expressar neste novo milênio, tudo nos aponta para uma urgência em reaprender, reconhecer e redefinir os novos conceitos, inclusive repensar a nossa própria existência. Contudo, devemos estar atentos para coisas que sempre estiveram presentes no pensamento do homem. Como nos diz Kabir, "onde quer que você esteja, existe um ponto de entrada”. (apud ROSS, 1999, p. 2, tradução nossa) Se esta frase em muito se aproxima dos conceitos mais atuais da arte e da tecnologia, sobretudo em redes, ao escolher Kabir, Bill Viola retoma um pensador do século $X V-X V I$.

Assim como Bill Viola, vimos em depoimentos de vários artistas uma afinidade espiritual, pela qual alguns pensadores antigos foram mencionados. $\mathrm{O}$ que nos leva a questionar: por que a arte, sobretudo a partir da metade do século passado, inspirou-se nas religiões orientais, como o sufi e o zen-budismo, mais especificamente?

Essa mesma questão parece ter inquietado Eco (1991a, p. 203-206), ao indagar: "Por que o Zen Budismo e por que agora?" Para Eco, os primeiros interesses pelo zen-budismo no Ocidente, mais especificamente na Itália, surgiram em 1959. Assim vejamos esta questão, à luz de suas teorias::

Certos fenômenos não aconteceram por acaso. Nesta descoberta do Zen pelo Ocidente pode haver muita ingenuidade e bastante superficialidade na troca de idéias e sistemas: mas se o fato acon-

1 "Onde você se encontra, encontra-se o ponto de entrada", Kabir. Em programação de computador, um ponto de entrada é um endereço de memória, correspondendo a um ponto no código de um programa que é pretendido como destino, um salto interno ou externo. Portanto, ao mencionar esta frase de Kabir, Viola também associa sua linguagem de vídeo a esse conceito contemporâneo de não linearidade. 
teceu, é porque determinada conjuntura cultural e psicológica favoreceu o encontro. [...] Há no Zen uma atitude fundamentalmente antiintelectualista, de elementar e decidida aceitação da vida em imediação, sem tentar justapor-lhe explicações que a tornariam rígida e matariam, impedindo-nos de colhê-la no livre fluir, em sua positiva descontinuidade. E talvez tenha dito a palavra exata. A descontinuidade é, tanto nas ciências quanto nas relações comuns, a categoria de nosso tempo: a cultura ocidental moderna destruiu definitivamente os conceitos clássicos de continuidade, de lei universal, de relação causal, de previsibilidade dos fenômenos: em suma, renunciou à elaboração de fórmulas gerais que pretendem definir o conjunto do mundo em termos simples e definitivos. Novas categorias ingressaram na linguagem contemporânea: ambigüidade, insegurança, possibilidade, probabilidade.

Ao se referir a alguns artistas, como John Cage, Eco (1991a, p. 213) ressalta que "no plano filosófico, Cage é intocável", mas coloca em dúvida se esse músico, através do zen, "está contribuindo para o exoterismo Zen perfeitamente ou para o campo musical, procurando uma lavagem mental de hábitos musicais adquiridos". Como podemos constatar, a partir de suas proposições, Eco (1991a) está ciente da importância e da presença do zen na cultura ocidental, sobretudo nos Estados Unidos, mas tem reservas quanto à sua prática, ou seja, se o Ocidente realmente chegou a entender essa filosofia oriental a ponto de poder aplicá-la em sua vida, no cotidiano e nas artes.

Para nós, as considerações pontuadas por Eco (1991a) são de extrema relevância no que se refere à obra dos artistas que se inspiram nos pensadores orientais, mas resta-nos perguntar: qual a essência da abordagem do assunto nos principais pensadores já mencionados?

Maulānā Gialāl al-Dīn Rūmī, mais conhecido como Rūmī, transcendeu fronteiras nacionais e étnicas, e, depois de sua morte, seus seguidores fundaram a Ordem Mevlevi, mais bem entendida como o Whirling Dervishes, na qual sua adoração é feita na forma de danças e cerimônias musicais, 
denominadas "sema”. Para Rumi (apud ARBERRY; NICHOLSON, 1996, p. xx) somente por meio da música, da dança e da poesia alguém podia alcançar o sema, que representa a jornada mística espiritual, uma ascensão através da mente e do amor, ou seja, do aperfeiçoamento. Nessa viagem, o investigador, simbolicamente, vira-se em direção à verdade, cresce por amor, abandona o ego, e alcança a perfeição; ao retornar dessa jornada, coloca-se a serviço da criação, sem discriminação de crenças, classes ou nações. (tradução nossa)

Na visão de George Ivanovich Gurdjieff, filósofo, músico e mestre espiritual, de descendência grega e armênia, nascido na fronteira entre a Rússia e a Turquia, a música era a arte que conduz a humanidade a um despertar. Sua obra musical evoca os cantos religiosos gregos e russos que Gurdjieff ouviu em sua infância. Gurdjieff influenciou inúmeros artistas, escritores e pensadores modernos, inclusive Frank Lloyd Wright. No texto Meetings with remarkable men (1963) e no ballet The struggle of the magicians (1914) estão presentes as mais diversas formas de explicar a filosofia de Gurdjieff, voltada para a verdade universal, o cosmos e a arte como forma de alcançar o sublime.

Em Kabir Das (apud VAUDEVILLE, 1998) um dos grandes poetas e músicos da Índia medieval, encontra-se o conceito filosófico de absoluto, ao qual a alma individual acaba se unindo. Um dos mais respeitados pensadores e poetas do sufismo, de família de tecelões, Kabir praticava e acreditava na união, na verdade e no absoluto. 



\section{Agnes Denes: Campos de Trigo - uma confrontação}

A obra da artista americana Agnes Denes, Wheatfield - A confrontation (Campos de trigo - uma confrontação) (1982), patrocinada pela Public Art Fund, em Nova lorque, à primeira vista, em nada se assemelha ao que muitos entendem como arte, visto que o signo indicial aponta para seu objeto dinâmico que é um campo de trigo como outro qualquer, e não à representação de um campo numa tela. Aqui, o campo de trigo é "real". 
Mas na concepção desta artista - em que arte e ciência possuem ambições semelhantes -, há aproximações e compreensões sobre a natureza e a complexidade das sociedades ocidentais na esfera de uma especulação filosófica. De acordo com o historiador e crítico de arte Peter Selz (1996, p. 147), Agnes Denes foi uma das primeiras artistas a trabalhar com sitespecific com interesse ecológico, em 1968, dando o nome de "eco-logic".

A partir dessa obra, temos a possibilidades de instaurar uma relação entre arte como um corpo político, destacando alguns elementos que podem ir do grão, passando pelos próprios processos presentes em uma plantação de trigo a outros que passam despercebidos na obra, ora em discussão. Ao considerarmos o grão como um signo desencadeador de um processo semiótico, teremos um percurso conhecido a percorrer, visto que sua origem e suas histórias já fazem parte de um imaginário popular milenar, que remonta ao período neolítico.

Por conseguinte, essas duas primeiras opções já seriam índices apontando para diversas relações de ordem social, financeira etc. Ao optar por outro corpus, a ser metaforicamente criado a partir dessa obra, para dialogar com as questões supracitadas, o espaço seria certamente mais instigante, pois nada mais estranho do que imaginar uma plantação crescendo saudavelmente, ainda que quase asfixiada pelos arranha-céus de uma grande metrópole. Ademais, quando contemplamos uma obra, o espaço não é necessariamente o primeiro elemento a ser identificado. Ainda no âmbito dessa possibilidade, este tipo de arte, Earth Art (se assim podemos denominá-la), não está apoiado apenas no objeto, mas, sobretudo, na experiência de espaço e no tempo, pois o observador pode se movimentar dentro da própria obra.

E quanto a Demeter? Seria possível endereçar a essa deusa da mitologia grega, responsável por todos os fenômenos e procedimentos ligados direta ou indiretamente à cultura da terra, uma releitura da sua trajetória durante o período em que roubaram sua Perséfone? Aqui, nesse campo, ela se esconde, e só sabemos da sua presença através da enunciação da própria artista, ou se o interpretante lógico conhecer a história dessa deusa. Ou melhor, como afirma Santaella (2007, p. 356), a seguir: 
Toda imagem representada, ou seja, corporificada em um suporte de representação, coloca em ação conceitos representativos que são próprios daquele suporte ou dispositivo. No caso do desenho ou pintura, os conceitos representativos devem ser de conhecimento da criação do autor das imagens. [...] quanto ao receptor da imagem, este também deve ter pelo menos certa familiaridade com os conceitos representativos, caso contrário a imagem não será decodificada como tal.

Contudo, todas essas tentativas de determinar apenas um corpo político na obra nos leva a conjecturas inesgotáveis, e, consequentemente, a interpretações que variam de interpretante para interpretante, como ressalta Santaella (2007), acima. Ao conceituar esse campo como um signo híbrido, ao invés de destacar elementos, podemos analisar a obra de uma maneira mais aberta, pela possibilidade de transpor os limites impostos pelas técnicas tradicionais da arte. Pois, se por um lado, ela é indicial, apontando diretamente para seu objeto direto, por outro lado, como signo icônico, ela nos encanta, propicia uma contemplação que somente a natureza é capaz de proporcionar. $E$, mesmo em se tratando de uma obra indicial, a fase icônica deve ser priorizada, visto que é no primeiro fundamento do signo que encontramos suas mais puras qualidades, que emergem da contemplação. Ao adentrar nesse local, as referências espaciais e perceptivas são provavelmente as primeiras que podem suscitar sensações diversas, como respirar o ar fresco e a brisa que vêm das águas do rio que correm sem cessar, caminhar pelo espaço, ficar parado observando as nuvens passar etc.

Thomas McEvilley, no artigo Philosophy in the land: since the 1960s (2004), destaca a poética que envolve a transformação natural desse campo, onde suas espigas ondeavam em direção ao rio Hudson, presenteando o observador com uma paisagem exuberante, onde todos os fenômenos naturais alteravam a paisagem. Os dias ensolarados de verão, o vento ao entardecer, a luz da cidade à noite refletindo-se no campo, onde todas as cores da natureza estavam presentes em sua plenitude; os diversos tons 
de verde e amarelo contrastando com a terra, o azul do céu e o cinza espelhado nos arranha-céus.

Para falar sobre a iconicidade do campo de trigo de Agnes Denes, nada mais apropriado do que trazer a obra de Waldo Emerson Nature (1983a) para esta reflexão. Ao dizer que o homem pode ser dono de muitas terras, mas nenhum deles pode ser dono da paisagem, Emerson se aproxima da confrontação proposta por Agnes Denes, nesse espaço onde as bolsas de valores oscilam nervosamente a cada minuto, enquanto o processo natural do passar do dia é lentamente desvelado. A arte, portanto, diferentemente da ciência, é um ícone; um signo que representa o seu objeto de tal modo que suas condições de significação com o signo não dependem da existência desse seu objeto. Como nos dizem Deleuze e Guattari (1992, p. 213) "a obra de arte é um ser de sensações, e nada mais: ela existe em si” e, Leão (2002, p. 158), "a contemplação é algo muito mais ativo que costumamos pensar. Dinamismo formativo. Para Deleuze e Guattari, contemplar é criar, é contração de sensação. A sensação, por sua vez, preenche em si mesma com aquilo que ela contempla”.

Ao transformar um terreno de detritos de aproximadamente $10.000 \mathrm{~m}^{2}$ em um saudável campo de trigo, localizado no coração do maior centro financeiro internacional, como um projeto de recuperação para uma área de aterro em Manhattan, Nova lorque, Agnes Denes, como o próprio título da obra já indica, confronta a sociedade capitalista, que prioriza valores que vão de encontro a valores humanos, por vários motivos. Primeiramente, pela intromissão na cidade, uma confrontação com a alta civilização. Segundo, a confrontação se dá pela comprovação da discrepância existente entre o valor do trigo dourado, saudável, colhido nesse campo, de US\$158 dólares, com o valor da terra, estimada em US\$ 4,5 bilhões de dólares. Portanto, o valor da terra em Manhattan e em outras capitais mundiais não é equivalente ao que ela (terra) produz, mas ao valor simbólico (imobiliário) e ao prestígio global que representam as corporações multinacionais. De imediato surge um corpo político que faz referência à ingerência, desperdício, fome mundial e interesses ecológicos. Um apelo às prioridades extraviadas. 
Ainda que quiséssemos nos distanciar dos índices, eles continuariam apontando para a Estátua da Liberdade, o World Trade Center e a área do Wall Street, que estão no seu entorno, e que são também símbolos da cultura americana. Mais uma vez retornamos a Peirce através de Santaella (1995, p. 52), que nos informa que "à Percepção interessa tudo aquilo que está no aqui e agora, entretanto só percebemos aquilo que estamos equipados para interpretar". Nesse sentido, Thomas McEvilley (2004) faz observações pertinentes, ao considerar a obra uma confrontação entre natureza e cultura ou o campo de trigo e os enormes arranha-céus que contornaram esse campo durante a estação de seu crescimento e florescimento.

Mesmo que outros aspectos estejam diluídos ou obscurecidos, como a relação com a deusa Demeter, enfatizada pela artista, a obra também sugere uma sensibilidade neolítica, embora um dos desejos de Agnes Denes, entre tantos outros, fosse que, através dessa obra, a natureza pudesse ressurgir renovada e evocar seus elementos, como horizonte, sol, sombra, nuvem, chuva, tempestade, vento, alvorada, dia e noite, entre outros.

Em parte, o ponto deste contraste estava sobre a fome mundial e o abuso da terra. Entretanto, o campo de trigo ainda é considerado um símbolo, um conceito universal que representa alimento, energia, comércio, negócio mundial e economia. Assim como no período neolítico, quando o homem cultivou o trigo para poder alimentar outras culturas, os grãos colhidos por Agnes Denes também viajaram por vinte e oito cidades ao redor do mundo numa exibição chamada "The International Art Show for the End of World Hunger", em 1992, incluindo o Rio de Janeiro.

Quanto às polêmicas discussões, que não apenas o novo propicia, mas toda arte que foge de seus cânones tradicionais, essa obra nos faz repensar o que é arte, e, a partir dela, a cada vez que olharmos a natureza em sua plenitude, vamos admirá-la em sua forma mais elevada, ou seja, como uma das obras de arte mais verdadeiras.

De acordo com a filosofia da natureza de Schelling (2001a), o processo natural parte do nascer, morrer e deixar sua semente no mundo - que são os processos inteligentes da natureza. Para Schelling (2001a), o universo e a natureza são pura liberdade. Ao mesmo tempo em que confronta o 
capitalismo mundial, abrigo, alimento, Agnes Denes traz de volta à arte contemporânea o sublime, a natureza, que segundo o conceito de estética, de Charles Sanders Peirce, é onde reside o kalos, o admirável.

\section{Campos de Girassóis: Anselm Kiefer e Vincent van Gogh}

De acordo com Osborne (1991, p. 59), existem três classificações que nos ajudam a entender a arte, a partir das duas últimas décadas do século passado até os dias de hoje.

A arte existe hoje no estado de pluralismo, nenhum estilo ou mesmo modo de arte é dominante; o pluralismo é o resultado da ruptura progressiva ou autodestruição do prévio projeto hegemônico do Modernismo, legalizado na pintura e na escultura durante os anos 1960 e início dos anos 1970 pela Arte Minimalista e a Arte Conceitual na radicalização do projeto do abstracionismo, em conjunção com o paralelo, mas não muito diferente da expansão da Pop; essa situação envolve a legitimação (ou pelo menos a ausência da deslegitimação da convicção) do "retorno" da pintura, e para a pintura figurativa e expressiva em particular, de uma forma ou de outra. (tradução nossa)

Dentro desse cenário pluralista, já abordado amplamente neste livro, sobretudo à luz das teorias de Danto (1998), a maioria delas condensadas em Horowitz e Huhn (1998), a pintura floresce no cenário artístico internacional depois de alguns anos, na década de 1980, à sombra dos objetos "desmaterializados". Este fenômeno de retorno à pintura concentrou-se na Europa, mais especificamente na Itália e na Alemanha, sendo que neste último país o neoExpressionismo apresentava uma pintura com forte carga identitária da cultura germânica.

A jovem geração de pintores alemães (1980), quase sempre radicada nos principais centros urbanos e culturais - Berlim, Düsseldorf, Hamburgo e Colônia -, mostrava uma arte próxima ao Romantismo e ao Expressionismo 
do início do século XX. Sendo filhos da Segunda Guerra Mundial, estes artistas escolhiam temas que estavam voltados para a história desse país, e assim destacam-se nomes como A. R. Penck, Anselm Kiefer, Georg Baselitz, Gerhard Richter, Jörg Immendorff e Markus Lüpertz. Estes e inúmeros outros artistas, inclusive de uma geração posterior, dos nossos dias atuais, abordam em suas pinturas temas com a predominância do figurativo - retratos, autorretratos, paisagens, espaços habitacionais, quartos, salas de estar e cenas do cotidiano público e privado -, geralmente em grandes formatos nos quais se pode perceber que o uso da fotografia é recorrente durante o processo de elaboração de seus trabalhos.

Segundo alguns teóricos, na obra desses pintores, há uma presença de obsolescência nos objetos, uma certa nostalgia, algo inóspito e a banalidade da existência cotidiana. $O$ realismo figurativo é encontrado mais precisamente nas pinturas de Neo Rauch, Tim Eitel, Norbert Bisky e Sophie von Hellermann, que são considerados como pintores da Neue Leipziger Schule ou Nova Escola de Leipzig, oriundos da Academia de Artes Visuais de Leipzig. Entre eles destaca-se Neo Rauch com temas voltados para trabalhadores, postos de gasolina e figuras de histórias em quadrinhos. Nas pinturas de Tim Eitel, o Realismo é quase fotográfico, com figuras isoladas e em alguns trabalhos elas surgem meditativas, como se observassem, ou mesmo contemplassem algo que está fora do quadro. Mas nosso interesse está especificamente voltado para a obra de Anselm Kiefer, um dos artistas alemães que mais contribuíram para o retorno da pintura nos anos 1980.

$\mathrm{Na}$ arte alemã, como nos informa Honnef (1994, p. 51):

Dominava o internacionalismo ao sufocar a própria herança cultural, esta parecia que pretendia, simultaneamente, esquecer a recordação do estilo do regime nazi. Os artistas alemães ansiavam por seguir as idéias artísticas vindas da França, dos EUA e, por vezes, também da Itália. A arte ocidental, principalmente as formas abstratas, tinham-se tornado sinônimo de liberdade graças à vitória dos aliados. 
No final do século XX, de acordo com Foster (1988, p. 197), temos testemunhado um reaparecimento da pintura, não só um renascimento de modos antigos como se fossem novos, mas também uma retomada de valores antigos, como se eles fossem necessários. Além desse reaparecimento, Foster admite a presença de certa aura na pintura e na fotografia, onde predomina a originalidade, junto às práticas artísticas mais contemporâneas.

Ao escolhermos a obra de Anselm Kiefer para encerrar este livro, levamos em conta a afinidade existente entre as teorias que podemos apresentar agora, retomando os conceitos vistos inicialmente. Trata-se, portanto, de um capítulo conclusivo pelas suas peculiaridades, pois quando iniciamos com a filosofia da natureza de Schelling (2001a), no século XVIII, os conceitos presentes nessa obra foram surgindo em artistas, a partir dos anos 1960. E, com eles, verificamos uma volta à natureza, como fonte de inspiração da arte dos dias atuais, tanto na fotografia, como na escultura e na pintura, inclusive, até mesmo, o retorno à pintura de paisagem. $\mathrm{E}$ a esse retorno, consideramos como um período de rememoração.

Porém, antes de abordarmos a homenagem de Anselm Kiefer a Vincent van Gogh, em forma de diálogo visual, consideramos importante apresentar Kiefer, bem como conceitos presentes na obra desse artista, conceitos estes que fazem parte da arte da nossa atualidade.

Anselm Kiefer abandonou os estudos em Direito e decidiu visitar o Monastério La Tourette, construído pelo arquiteto francês Le Corbusier. Seu objetivo era conhecer mais de perto os métodos pelos quais esse arquiteto trabalhava com os materiais, sobretudo o concreto, de onde extraiu uma ideia abstrata sobre religião. La Tourette é um espaço que chama atenção pela harmonia existente entre espaço, assim como materiais que fazem uma associação à vida monástica, ou seja, simplicidade e aproximação à natureza. Além de suas obras, Le Corbusier era conhecido como um homem que entendeu o paradigma modernista, o embate dialético entre a tradição e a modernidade, entre a herança artística e o tecnicismo emergente do século XIX.

Benton (1987) define a arquitetura de Le Corbusier como uma obra que possui uma dimensão espiritual, visto que, em seus depoimentos, sua 
vida profissional e particular não estavam separadas. Ele acreditava numa existência voltada para a união coletiva, que em muito se aproxima do pragmatismo de Peirce, do admirável, e do absoluto de Shelling, e expressava o quanto havia lutado a favor do racionalismo, fortemente imbuído nele por uma vida ativa e pela ciência. E Le Corbusier reconhecia a inata e intuitiva ideia de um ser supremo que the era revelado aos poucos pela contemplação da natureza. Essa afinidade com os elementos naturais o levou, depois da Segunda Guerra Mundial, a iniciar uma investigação de signos figurativos do homem, da natureza, de materiais e do espaço, por entender que a natureza estava permeada por signos da história da humanidade.

Foi então, a partir dessas informações e o convívio com o espaço La Tourette, que Anselm Kiefer decidiu fazer uma arte que estivesse voltada para esses princípios. E, segundo Auping (2005, p. 24), "por mais de três décadas Kiefer explorou a grande pergunta desalentadora: por que conceitos tal como transcendência e a ideia de um ser superior têm existido por toda a história?" (tradução nossa) Em busca de respostas para seus questionamentos, Kiefer passa a investigar os materiais e elementos do mundo natural como um começo para seu trabalho, a partir das árvores, das florestas, os ciclos de vida e a mitologia de serpentes e anjos, como meios de criar um diálogo entre céu e terra. Para esse artista, o universo contém espírito e está em um processo ininterrupto de criação e destruição, onde o fogo, os metais derretidos e suas possíveis combinações, ao se fundirem, são, ao mesmo tempo, transformação e criação. Seu objetivo é passar um conteúdo que faça parte de sua história de vida através da matéria na arte.

Para Colpitt (2006, p. 104), as paisagens de Kiefer são campos de história, de guerra, de uma Alemanha que carrega o peso de uma trajetória peculiar, e esse pintor abre espaço nos seus quadros para incluir a mitologia e o holocausto. (tradução nossa) E, de acordo com Auping (2005, p. 38), algumas de suas pinturas aludem à mitologia grega, e a referência que Keifer faz a Hércules está acompanhada do material devidamente escolhido:

O chumbo é um material muito importante. É, naturalmente, um material simbólico, mas também a cor é muito importante. Você 
não pode dizer que ele é claro nem escuro. É uma cor ou não-cor com a qual me identifico. Eu não acredito no absoluto. A verdade é sempre cinzenta. (tradução nossa)

Como podemos observar, nem sempre as declarações dos artistas coincidem com as interpretações e investigações feitas por teóricos. Nesse caso, não se trata de discordância, mas algo que é próprio da iconicidade do signo da arte, que faz com que nem mesmo o artista tenha uma explicação exata de sua obra. Sendo passível de várias interpretações, cada interpretante irá abordá-la mediante seu repertório intelectual. E quanto à paisagem? Como ela surge depois de tanto tempo fora do contexto artístico do século $X X$ ?

Nessa reintrodução da paisagem na pintura, a partir do final do século $\mathrm{XX}$, encontramos vários conceitos de teóricos e críticos que nos levaram a refletir sobre a obra de Anselm Kiefer. Mas foi com Andrew Benjamin (1991, p. 95), filósofo especializado em arte contemporânea, que primeiramente encontramos as principais considerações que nos ajudaram a aprofundar as investigações sobre esse diálogo com Vincent van Gogh. Andrew Benjamin nos diz que, ao retornar ao campo da repetição, o primeiro elemento que deve ser notado é a presença de paisagem, que cede a um campo de interpretação. $E$ é nesse período que a arte libera esse tipo de pintura de seu conceito tradicional, para incluir a história "como uma obra de rememoração". (tradução nossa)

Por conseguinte, podemos considerar que a presença da paisagem nas pinturas de Kiefer nos leva a refletir agora, sobre o sentido lato da palavra paisagem. Trata-se de paisagens sígnicas de campos de representação, campo de retorno e repetição, o lugar de uma determinada representação. Sabemos que todo retorno implica uma repetição, por isso ele está contaminado de algo do passado e algo do presente, e podemos dizer, então, que, de uma forma sutil, existe uma hibridização de tempo na paisagem de Kiefer. Sendo uma palavra de amplos significados, devemos lançar um olhar mais especulativo a essa nomenclatura. $O$ retorno que caracteriza a pintura de Kiefer vai além da técnica, pois, diferentemente das paisagens 
características do Romantismo e as de Van Gogh, o que Kiefer traz para suas paisagens são memórias de um período que marcou a história da humanidade, ou seja, um "campo" liberado pela contemporaneidade, para a inclusão da história.

Para Honnef (1994, p. 52), Kiefer não aborda as forças primitivas nem as mistifica, pois, nas suas paisagens, "a terra apresenta-se queimada, é uma terra apocalíptica. As suas pinturas recordam a imagem da Natureza apresentada pelos românticos e pelos Expressionistas, mas revelam as graves ameaças que pairam sobre o nosso mundo". Devido a essa primeira característica do trabalho de Kiefer, isto é, a variedade de elementos naturais e a dimensão das obras, sua arte tem sido considerada memorável, termo que vai além de um mero adjetivo, algo que o ultrapassa e torna-se um conceito, pelos significados que abrange. A memória, nesse caso, refere-se a tudo aquilo que está relacionado às funções psíquicas; um fenômeno em processo de devir que não exclui seus antônimos, isto é, aquilo também que é esquecido. Nesse sentido, o ato de celebrar eventos, perpetuar momentos efêmeros, relembrar o passado através de diversos tipos de representação, por sua abrangência, tem sido considerado por alguns teóricos como sendo um monumento.

Esse monumento é um espaço aberto que permite que, tanto a lembrança como a sua ausência, possam transitar em processo dinâmico, ainda que muitas vezes pareça estático. Todo esse arsenal da memória faz com que o homem possa trazer à tona as experiências com o mundo real, que se dão mediante a apreensão do que é visto e vivido, pois estamos sempre preenchendo lacunas com o esforço da imaginação em busca de significados. Não existe o que está esquecido, haverá, então, a oportunidade de lembrar em outro contexto, em outro momento, de uma outra forma, porque os restos dos significados estão escondidos em nós.

Devido à representação de paisagens de terras desoladas, a arte de Kiefer se inclui nesse conceito de tempo, que tem sido associado ao que Walter Benjamin (1986b) denomina de Angelus Novus, inspirado na aquarela de Paul Klee, realizada em 1920. Segundo Walter Benjamin (1986b, p. 249), esse anjo: 
Representa o anjo da história, com ares de quem se assusta com o presente, procura voltar para o passado, mas é empurrado para frente pelo sopro do futuro. De asas dilatadas e boca aberta, o Angelus Novus enxerga na cadeia de acontecimentos as catástrofes que se acumulam, mas não pode se deter para reconstruir o tempo, porque não pode fechar suas asas, elas estão presas às novas tragédias, às injunções do cotidiano. [...] A pintura de Klee intitulada 'Angelus Novus' mostra um anjo pronto para se afastar de algo que ele contempla fixamente. Seus olhos fitam, sua boca está aberta, suas asas espalhadas. Assim é a maneira pela qual alguém pode perceber o anjo da história. Seu rosto está em direção ao passado. Onde percebemos uma corrente de acontecimentos, ele vê uma catástrofe, que mantém ruínas que se amontoam sobre ruínas e se lança frente os seus pés. $\bigcirc$ anjo gostaria de permanecer, acordar o morto, e tornar inteiro o que foi esmagado. Mas uma tempestade sopra do Paraíso; e o agarra pelas suas asas com tal violência que o anjo não pode mais fechá-las. Esta tempestade irresistivelmente impede-o de ir ao encontro do futuro, ao qual suas costas estão viradas, enquanto a pilha de escombros diante dele cresce skyward. Esta tempestade é o que nós chamamos de progresso.

Através da descrição da imagem do anjo de Paul Klee, Walter Benjamin, (1986b) revela seu maior desejo em recontextualizar a história, o que envolve uma rejeição de linearidade e historicidade e um rompimento de temporalidade, resultando em um momento revolucionariamente carbonizado do "Agora-Tempo". Santaella (2007, p. 203) sublinha que esse anjo interpretado por Walter Benjamin, em menos de um século, transmutou-se e "já não deixa atrás de si uma montanha de ruínas; as montanhas agora rodeiam o anjo”. O Angelus Novus a que Santaella se refere é também, para Walter Benjamin, o conceito de aura, um conceito axial, e na obra de Kiefer todos esses conceitos estão presentes como um desafio para que a história seja relembrada, repensada, refletida, ou mesmo reconstruída, em que a imaginação passa a desempenhar um papel de investigadora 
dos elementos sensíveis para reproduzir e/ou representar as lembranças de uma cultura.

Além da pintura, o tempo permeia toda a arte de Kiefer. Segundo Colpitt (2006, p. 104), esse artista possui uma enorme atração por livros, pelo fato deles serem manifestações de tempos, ou seja, o tempo que envolve o escritor para escrever, e o tempo que envolve a sua leitura, página por página. Para Kiefer, existe uma diferença entre os livros e as pinturas, pois as pinturas já são propriedades do tempo, basta entrar num quarto e ela se apresenta, tudo está aí imediatamente. O observador pode ficar na frente dela pelo tempo que quiser, para tentar entendê-la melhor, mas não tem que seguir isso através de qualquer comprimento de tempo. Já em referência aos livros, eles são realizados para serem apreendidos de duas maneiras: livros que podem ser manuseados e livros que ficam entreabertos; esses últimos são livros que podem ser contemplados como pinturas. São trabalhos que estão no meio, entre a aparição e o tempo. Esse interesse de Kiefer por livros surge em suas pinturas através de palavras, frases, nomes, que muitas vezes aparecem em forma de verbos que denotam uma atividade, ao invés de uma identidade decorrente de certas conexões com a história da Alemanha, à qual esse pintor não cessa de se referenciar. Na sua pintura Your golden hair Margarette (1981), a repetição de partes do poema de Celan, referindo-se a Icarus, filho de Daedalus, configura a metonímia e a citação. Portanto, a paisagem histórica se mistura à paisagem mitológica, e a repetição estabelece a relação entre representação e o lugar da representação. (tradução nossa)

\section{Anselm Kiefer e Van Gogh no Sul da França}

Desde 1993, Anselm Kiefer vive e trabalha no seu Hill Studio (EstúdioColina), em Barjac, a alguns quilômetros fora de Nîmes, ao sul da França. La Ribaute, como é chamado o estúdio com seus bens adjacentes estendese por aproximadamente 35 hectares de terra e caracteriza um complexo extraordinário de corredores, cavernas, velhas edificações industriais e espaços privados. Esse espaço serve de repositório de múltiplas impres- 
sões e influências, repleto de objetos encontrados de uma variedade de lugares diferentes: motor de avião de bombardeio da Segunda Guerra Mundial, assentos de cinema, várias camas de hospital etc. Todos armazenados em containers para serem usados em suas obras; o local também possui, além de campos, várias estufas em que Kiefer cria plantas para usar nos seus trabalhos, sobretudo girassóis gigantes. Algumas vezes o espaço do Estúdio-Colina, em Barjac, torna-se um lugar onde a arte e a paisagem se fundem à medida em que pinturas são deixadas ao ar livre. Vejamos o depoimento de Kiefer (apud COLPITT, 2006, p. 110) no trecho a seguir:

Necessito da natureza, [...] o tempo variável, o calor, o frio. Às vezes eu deixo minhas lonas do lado de fora na chuva. Jogo ácido, terra ou as rego. Eu não uso tintas industrialmente fabricadas. A tinta vermelha não é vermelha, por exemplo, é ferrugem, ferrugem real. Estou constantemente experimentando com novos processos. (tradução nossa)

Diferentemente do trabalho desenvolvido por Kiefer no seu país de origem, as pinturas realizadas no sul da França falam visualmente sobre o cosmos, palavra derivada do grego kosmos - que significa disciplina -, o Universo em seu conjunto e sua ordenação, estrutura universal em sua totalidade. Na citação que se segue, podemos entender o quanto Kiefer, do mesmo modo que Van Gogh, apaixonou-se pelos girassóis.

Anselm Kiefer também se apaixonou pelos girassóis depois que se mudou para a Provence e para ele as sementes escuras da flor tornam-se uma espécie de antimatéria em galáxias escuras. Esta melancolia germânica surge do desejo impetuoso de possuir o fogo do conhecimento total enquanto sabendo que não é permitido. $\bigcirc$ artista, no entanto, pode ser cobrado, como Prometheus, por roubar um instante deste conhecimento divino para compartilhá-lo 
com a espécie humana em sua viagem em direção a uma suposição final do total cósmico. (COLPITT, 2006, p. 109, tradução nossa)

Ali, em Barjac, próximo de onde Van Gogh pintou seus últimos quadros, Kiefer passou a usar girassóis mortos, que, segundo ele, representam galáxias escuras, o reverso do poder de luz. Nas suas pinturas há uma variedade de imagens noturnas, pois, no seu entendimento, antes da luz era o vazio e ao vazio tudo deve retornar. De acordo com Auping (2005, p. 59), os girassóis e as sementes usados na pintura de Kiefer são uma explícita homenagem a Vincent Van Gogh. Manget, título de uma das suas obras mais recentes, é composta de um sol central acompanhado de chamas de girassóis, onde o fogo possui um significado importante. (tradução nossa) Sol invictus [Invincible Sun] e Die Klugen Jungfrauen incluem vários girassóis em chamas junto a sementes dessa flor.

De acordo com Rose (1998), a série In falling stars (2007), composta por pinturas e instalações, apresenta girassóis secos, e o observador é confrontado com uma qualidade emotiva da obra proveniente do uso dessa flor, bem como de suas excepcionais texturas, como as camadas de tinta cobertas com materiais orgânicos: terra, palha, sementes de girassóis, incrustações densas, barro, cinza etc. Deste modo, a paisagem de Kiefer difere do gênero tradicional dessa pintura e, embora sublime, ela não surge como uma paisagem; ela é criada pelo observador, por todos os materiais compostos. Rose (1998) nos informa ainda que, ao inspirar-se nos girassóis e céus estrelados de Van Gogh, Kiefer relaciona-os aos grandes acontecimentos cósmicos, tentando criar um elo entre o mundo terrestre e o mundo celestial, entre a realidade e o imaginário.

Porém, segundo Andrew Benjamin (1996, p. 83), as pinturas não são ilustrações de interesses teóricos; diferentemente, elas devem ser melhor compreendidas como formulação e propostas para certos problemas. Elas materializam, trazem à tona, aquilo que não pode estar presente, ao mesmo tempo, "as pinturas não são mais uma ocasião para ver anomalias dentro de uma representação [...], elas tornaram-se desempenhos de ontologias profundamente ressonantes”. (tradução nossa) 
Nas considerações acima, Andrew Benjamin (1996) descreve uma das principais características da arte contemporânea, ou seja, a partir da arte conceitual é necessário entender a arte com base em diversos ângulos. Portanto, devido à repetição da paisagem e girassóis, que, nesta questão, pode ser considerada uma visão geral da lógica outra vez e de novo, ou seja, outra vez, mas de uma nova maneira, há uma diferença considerável entre o tempo do objeto ou acontecimento lembrado e o presente. $O$ tempo do objeto ou acontecimento lembrado é sempre diferente do tempo em que ele aconteceu, é outro tempo.

Nas pinturas de Anselm Kiefer, além dos materiais - como o uso dos girassóis para homenagear Van Gogh -, ele escreve os nomes de seus ídolos. A essa escrita, Roland Barthes (1979), considera apenas o ato gráfico de dedicar que, para ele, é um desses verbos a que os linguistas chamaram de performativos. Os nomes são como aqueles jarros que lemos em não sei qual conto de As mil e uma noites: os gênios estão presos dentro deles. Se você abrir ou quebrar o jarro, o gênio sai, eleva-se, dissipa-se como fumaça e enche todo o ar: quebre o título e toda a tela se esvai, porque o seu sentido se confunde com o próprio ato de enunciá-los. E o que é a arte senão um constante enunciar? Dela não devemos esperar mais do que ela já proporciona àqueles que têm o poder da sublime experiência e a qualidade do sentimento estético, considerado como a mais difícil das sensibilidades. Por isso, para Barthes (1979), dedicar é o gesto real pelo qual alguém apresenta o trabalho que fez à outra pessoa que ama ou admira. Esse amor, para Peirce, é o projeto agápico, no seu conceito de estética, aquilo que é admirável, que gera inteligibilidade, conhecimento e crescimento.

Enquanto o principal objetivo de Vincent van Gogh era poder captar a qualidade da luz, Anselm Kiefer investiga materiais e grandes espaços para expressar visualmente suas ideias, e explora a arte de uma maneira metafísica, ao invés do aspecto psicológico. À primeira vista, as pinturas de girassóis de Van Gogh são meramente naturezas mortas; e não obstante diferenciarem-se das paisagens e instalações de Anselm Kiefer, como estes dois artistas comunicam visualmente suas ideias através dessa flor? 
A palavra girassol, conhecida universalmente, vem do grego helianthus - helios de sol e anthos de flor. Símbolo do deus sol em várias culturas, incluindo os astecas e os incas dentre outros. Seu centro possui um padrão definido, com uma organização de espirais interconectadas em que os números das espirais da esquerda e da direita são números sucessivos da série de Fibonacci. Há, aproximadamente, 34 espirais em uma direção e 55 em outra, chegando-se a 89 e 144, respectivamente. Daí o interesse pela sua definição que dá espaço a teorias das mais complexas. No texto de Bataille (1986), encontramos algumas passagens sobre esse assunto, que servem de contribuições a nossas reflexões. Pelo interesse na obra de Van Gogh, Bataille (1986) desconstrói o conceito tradicional do girassol e seu movimento em direção à vida e à luz, associando-o a um sol que queima, e que vai além da sua luminosidade e da qualidade das cores. Opostamente, Bataille (1986) destaca uma pintura desse pintor que representa girassóis mortos e queimados pelo sol, ao que ele vê semelhanças entre Van Gogh e Prometheus, que roubou o segredo do fogo e foi punido pelos deuses.

Ao discorrer sobre a relação entre o girassol, a obra e o artista, Lawrence (1998, p. 173) traz outras contribuições ao nosso debate:

Quando Van Gogh pinta girassóis, ele revela, ou alcança, a relação nítida entre si, como homem, e o girassol, como girassol, num breve momento de tempo. Sua pintura não representa o girassol em si. Nós nunca devemos saber o que o girassol realmente é. [...] A visão da tela é eternamente incomensurável com a tela, ou a tinta, ou Van Gogh como um organismo humano, ou o girassol como um organismo botânico. Você não pode ponderar nem medir nem mesmo descrever a visão na lona. Ela apenas existe, para the dizer a verdade, na quarta dimensão. No espaço dimensional não tem nenhuma existência. É uma revelação da relação aperfeiçoada, num certo momento, de um homem e um girassol. Não é nenhum homemno-espelho nem uma flor-no-espelho nem está acima ou abaixo e através de alguma coisa. Está entre tudo na quarta dimensão. E esta relação aperfeiçoada entre homem e seu universo do ambien- 
te circundante é vida em si para a humanidade. E tem esta qualidade da quarta dimensionalidade da eternidade e da perfeição. Mas isto é momentâneo. Homem e girassol desaparecem num momento, no processo de formar um novo relacionamento. A relação entre todas as coisas muda dia após dia, numa ação secreta e sutil de mudança. Logo a arte, que revela ou atinge a outro relacionamento perfeito, será para sempre nova. (tradução nossa)

Assim como para Bataille e Lawrence, para Derrida (1976), tanto na linguagem como na arte, o signo não é fixo nem estável, ele muda de acordo com a sua aplicação e localização, assim como o sol e o girassol. Ao abordamos esses conceitos, nos aproximamos da filosofia de Peirce, no que diz respeito ao conceito de movimento, continuidade, ou seja, como o signo flui e cresce, como o signo vai e retorna renovado, o mesmo e ao mesmo tempo, um outro, para poder construir o projeto agápico, sua principal noção de estética.

Ao arriscarmos apontar a presença, na obra de Anselm Kiefer, de características que podem ser associadas ao pragmatismo de Peirce, destacamos entre outros depoimentos já apresentados anteriormente, o Praemium Imperiale conferido a esse artista pela Japan Art Association, em 1999. Kiefer demonstra um complexo engajamento crítico com a história, na convicção de que a arte pode curar uma nação traumatizada e um mundo dividido. Através de pinturas épicas, feitas em grandes telas, representa visualmente a história da cultura alemã com a ajuda de descrições de figuras como Richard Wagner, Goethe, dentre outras celebridades. Essa maneira de ver a função da arte como um meio para guiar o mundo através do esforço humano, faz com que ele seja um dos artistas mais pesquisados na nossa atualidade.

A maioria dos autores contemporâneos, sobretudo os mais especializados na semiótica peirciana, a exemplo de Santaella, considera uma tarefa difícil identificar todas as histórias misteriosas e os sistemas de crença subjacentes à construção dos significados existentes na arte. Afinal, o observador se aproxima da obra pelo poder emotivo que dela deriva através 
de sua escala teatral e materiais evocativos que emanam da contemplação. Do mesmo modo, Deleuze e Guattari (1992, p. 272) também elucidam:

A sensação é contemplação pura, pois é pela contemplação que se contrai, contemplando-se a si mesmo à medida que se contempla o elemento. [...] Plotino podia definir todas as coisas como contemplações, não apenas os homens e os animais, mas as plantas, a terra e as rochas. [...] A planta contempla contraindo os elementos dos quais ela procede, a luz, o carbono e os sais, e se preenche a si mesma com cores e odores que qualificam sempre sua variedade, sua composição. 



\section{REFERÊNCIAS}

ADAMS, Laurie Schneider. The methodologies of art: an introduction. Colorado: Westview Press, 1966.

ALEXENBERG, Mel. A semiotic taxonomy of contemporary art forms. Studies in Art Education, Reston, v. 17, n. 3, p. 7-12, 1976.

Semiotic redefinition of art in a digital age. In: Semiotics and visual culture: sights, signs, and significance. Reston: National Art Education Association; Debbie Smith-Shank, 2004. p. 124-131.

ALLOWAY, Lawrence. American pop art. New York: Whitney Museum of America, 1974.

ALMEIDA, Custodio. Hermenêutica e dialética: dos estudos platônicos ao encontro com Hegel. Porto Alegre: Edipucrs, 2002.

ALSOP, Joseph. The rare art traditions: the history of art collecting and its linked phenomena wherever these have appeared. New York: Harper and Row, 1982.

ANDERSON, Douglas R. Creativity and the philosophy of C. S. Peirce. Dordrecht: Martinus Nijhoff Publishers, 1987.

ARBERRY, A. J.; NICHOLSON, Reynold. The essential Rumi. Translated by Coleman Barks; John Moyne. San Francisco: Harper Collins, 1996.

ARCHER, Michael. Arte contemporânea: uma história concisa. Tradução Alexandre Krug; Valter Lellis Siqueira. São Paulo: Martins Fontes, 2001.

ARGAN, Giulio Carlo. Arte moderna: do lluminismo aos movimentos contemporâneos. Tradução Denise Bottmann; Federico Caroti. São Paulo: Companhia das Letras, 2002.

ARISTÓTELES. Poética. Tradução Eudoro de Souza. São Paulo: Abril Cultural, 1973.

Organon. Tradução do grego e notas de Pinharanda Gomes. Lisboa:

Guimarães, 1985. p. 123-169. (v. I)

ARNHEIM, Rudolf. Arte e percepção visual: uma psicologia da visão criadora. Tradução Ivone Terezinha de Faria. 10. ed. São Paulo: Pioneira, 1996. 
ASCOTT, Roy. Is there love in the telematic embrace? In: STILES, Kristine; SELZ, Peter. Theories and documents of contemporary art. (Ed.). Berkeley: University of California Press, 1996. p. 491-498.

Consciousness reframed: art and consciousness in the post-biological era. Newport: University of Wales Press, 1997.

AUGÉ, Marc. Não lugares: introdução a uma antropologia da supermodernidade. Campinas, SP: Papirus, 1994.

AUMONT, Jacques. A imagem. Tradução Estela dos Santos Abreu. São Paulo: Papirus, 1993.

AUPING, Michael. (Ed). Anselm Kiefer: heaven and earth. London: Prestel, 2005.

BACHELARD, Gaston. A poética do espaço. Tradução Remberto Francisco Kuhnen; Antônio da Costa Leal; Lídia do Valle Santos Leal. São Paulo: Nova Cultural, 1988.

BAL, Mieke. Louise Bourgeois' spider: the architecture of art-writing. Chicago: University of Chicago Press, 2001.

BARTHES, Roland. Cy Twombly. Catalogue raisonné des oeuvres sur papier: 1973-1976. Milan: Multipha: Yvon Lambert, 1979.

The death of the author: image, music, text. Translated by Stephen Heath. New York: Hill and Hang: The Noonday Press, 1977.

From work to text. In: WALLIS, Brian (Ed.). Art after modernism: rethinking representation. New York: New Museum of Contemporary Art; Boston: David R. Godine, 1991.

A mensagem fotográfica. In: LIMA, Luiz Costa. (Org.). Teoria da cultura de massa. 2. ed. Rio de Janeiro: Paz e Terra, 1978. p. 303-316.

A câmara clara: nota sobre a fotografia. Tradução Júlio Castañon Guimarães. Rio de Janeiro: Nova Fronteira, 1980.

1964

Elements of semiology. New York: Hill and Hang: The Noonday Press,

Elementos de semiologia. São Paulo: Cultrix, 1988.

O óbvio e o obtuso. Tradução Lea Novais. Rio de Janeiro: Nova Fronteira, 1990.

BATAILLE, Georges. Van Gogh as Prometheus. Translated by Annette Michelson. October, v.1, n. 36, p. 111-127, spring 1986.

BAUDELAIRE, Charles. Oeuvres completes I. Paris: Gallimard, 1976. 
BAUDRILLARD, Jean. Simulacros e simulação. Lisboa: Relógio D’Água, 1991.

BEARDSLEY, M. C. Aesthetics form classical Greece to the present. New York: Macmillan, 1966.

Earthworks and beyond contemporary art in the landscape. London; New York: Abbeville Press, 1998.

BECEYRO, Raul. Ensayos sobre fotografia. México: Arte y Libros, 1980.

BECKLEY, Bill; SHAPIRO, David. (Eds.). Uncontrollable beauty: towards a new aesthetics. New York: Allworth Press, 1998.

BELTING, Hans. Likeness and presence: a history of the image before the era of art. Translated by Edmund Jephcott. Chicago: University of Chicago Press, 1994.

BENFEY, Christopher. Objects of beauty: still lifes and natures mortes. New York: The Museum of Modern Art, 1997.

BENJAMIN, Andrew. Kiefer's approaches. In: BENJAMIN, Andrew; OSBORNE, Peter. (Eds.). Thinking art: beyond traditional aesthetics. London: Institute of Contemporary Arts, 1991. p. 95-109.

Art, mimesis and the avant-garde: aspects of a philosophy of difference. Berkeley: University of California Press, 1996.

BENJAMIN, Walter. Pequena história da fotografia. In: Magia e técnica, arte e política: ensaios sobre literatura e história da cultura. Tradução Paulo Sérgio Rouanet. 2. ed. São Paulo: Brasiliense, 1986a. p. 91-107. (Obras escolhidas, 1).

A obra de arte na época de sua reprodutibilidade técnica. In: LIMA, Luiz Costa. (Org.). Teoria da cultura de massa. 4. ed. Rio de Janeiro: Paz e Terra, 1990. p. 207-240.

Sobre o conceito de história. In: Magia e técnica, arte e política: ensaios sobre literatura e história da cultura. Tradução Paulo Sérgio Rouanet. 2. ed. São Paulo: Brasiliense, 1986b. p. 222-232. (Obras escolhidas, 1).

Charles Baudelaire: um lírico no auge do capitalismo. Tradução José Carlos Martins Barbosa; Hermerson Alves Baptista. 3. ed. Rio de Janeiro: Brasiliense, 2000. (Obras escolhidas, 3).

The autor as producer. In: Selected Writings, 1927-1934. Translated by Rodney Livingstone et al. Cambridge: Harvard University Press, 1986. p. 768-782. (v. 2)

Illuminations. London: Fontana, 1992.

Magia e técnica, arte e política: ensaios sobre literatura e história da cultura. Tradução Paulo Sérgio Rouanet. São Paulo: Brasiliense, 1994. (Obras escolhidas, 1). 
BENTON, Tim. The sacred and the search for myths. In: RAEBURN, Michael; WILSON, Victoria. (Eds.). Le Corbusier: architect of the century. London: Arts Council of Great Britain, 1987. p. 238-245.

BERGER, John. Ways of seeing. New York: Viking Books, 1987.

BERNADAC, Marie-Laure; OBRIST, Hans-Ulrich. Louise Bourgeois Destruction of the father, reconstruction of the father: writings and interviews, 1923-1997. Cambridge: The MIT Press, 1998.

BOIS, Yve-Alain; BUCHLOH, Benjamin; FER, Briony. Gabriel Orozco. Conaculta, Mexico: Turner: A\&R Press, 2007.

BOIS, Yve-Alain; KRAUSS, Rosalind. Formless: a user's guide. New York: Zone Books, 1997.

BOLTON, Richard. The context of meaning. Cambridge: The MIT Press, 1993.

BORGES, Jorge Luis. História da eternidade. Tradução Carmem Cirne Lima. 2. ed. São Paulo: Globo, 2006.

From allegories to novels. In: Other inquisitions: 1937-1952.

Translated by Ruth L. C. Simms. Austin: University of Texas Press, 1964. p. 155156.

Obra completa. Buenos Aires: Emecé, 1974.

Obra poetica. Madri: Alianza, 2002.

BORRAS, Maria Lluïsa; ZAYA, Antônio. Cuba Siglo XX: modernidad y sincretismo. Barcelona: Centro Atlantico de Arte Moderno: Centre D’Art Santa Monica, 1996.

BOURGEOIS, Louise. Louise Bourgeois: interview with Donald Kuspit (1988). In: STILES, Kristine; SELZ, Peter. (Ed.). Theories and documents of contemporary art. Berkeley; London: University of California Press, 1996. p. 38-39.

Ode a lOubli [Ode to forgetfulness], livro artesanal composto de fragmentos de tecidos. [S.I.]: [s.n.], 2004.

BREY, Ricardo. Depoimento do artista para Universalis. Universalis, São Paulo: Bienal Internacional de São Paulo, XIII, São Paulo: Fundação Bienal de São Paulo, 1996.

Eem adem die vormen beweegt [Um alento movendo formas]. Entrevista a Dirk Pültau. Gent, GE, 22 jan. 1993.

BROWN, Louise Fargo. Ideas of representation. Journal of Modern History, New York, v. 7, n. 1, p. 23-40, 11 mar. 1939. 
BUCHLOH, Benjamin H. D.; Jean-Hubert Martin. The whole earth show. Art in America, New York, v. 77, n. 5, p. 150-159; 211-213, may 1989.

BUCHLOH, Benjamin H. D.; RUIZ, Alma. Gabriel Orozco. Los Angeles: The Museum of Contemporary Art, 2000.

BUCHLOH, Benjamin H. D. Neo-avantgarde and culture industry: essays on european and american art from 1955 to 1975. Cambridge: The MIT Press, 2001.

BUCK-MORSS, Susan. Dialectics of seeing: Walter Benjamin and the arcades project. Cambridge: The MIT Press, 1989.

BURGIN, Victor et al. On the art of fixing a shadow: one hundred and fifty years of photography. Chicago: Art Institute of Chicago: National Gallery of Art Washington: Los Angeles County Art Museum, 1989.

BUSKIRK, Martha. The contingent object of contemporary art. Cambridge: The MIT Press, 2003.

CAGE, John. Jasper Johns: stories and ideas. In: A year from monday: new lectures and writings. Middletown: Wesleyan University Press, 1967. p. 73-84.

CALDER, Alexander. Calder: an autobiography with pictures. New York: Pantheon Press, 1977.

CALVINO, Ítalo. Eremita em Paris. Tradução Roberta Barni. São Paulo: Companhia das Letras, 2006.

Seis propostas para o próximo milênio. São Paulo: Companhia das Letras, 1990.

CANCLINI, Néstor García. Culturas híbridas: estratégias para entrar e sair da modernidade. 4. ed. São Paulo: Edusp, 2006.

CAPRA, Fritjof. Pertencendo ao universo: explorações nas fronteiras da ciência e da espiritualidade. Tradução Maria de Lurdes Eichenberger; Newton R. Eichenberger. São Paulo: Cultrix, 1999.

CARERI, Francesco. Walkscapes: walking as an aesthetic practice (land \& scape). Barcelona; Mexico: Gustavo Gili, 2002.

CARLIN, John; FINEBERG, Jonathan. Imagining America: icons of 20th century American art. New Haven: Yale University Press, 2005.

CARROLL, Lewis. As aventuras de Alice no país das maravilhas. Tradução S. Uchoa Leite. São Paulo: Summus, 1980.

CELANT, Germano. (Ed.). Arte povera: conceptual, actual or impossible art? London: Studio Vista, 1969. 
CHIARELLI, Tadeu. $O$ tridimensional na arte brasileira dos anos 80 e 90: genealogias, superações. In: RIBENBOIM, Ricardo. (Org.). Tridimensionalidade na arte brasileira do século XX. São Paulo: Itau Cultural, 1997. p. 170-171.

15 Artistas brasileiros colocando dobradiças na arte contemporânea. São

Paulo, 1996. Catálogo de exposição promovida por Itau Cultural no MAM-SP. p. 3.

CHIPP, Herschel B. (Ed.). Theories of modern art. A source book by artists and critics. Berkeley; Los Angeles; London: University of California Press, 1968.

Etapas da arte contemporânea. São Paulo: Nobel, 1985.

Teorias da arte moderna. Tradução Waltensir Dutra et al. São Paulo: Martins Fontes, 1999.

CHISHOLOM, Hugh. Representation. In: OXFORD Encyclopaedia Britanica. 11 $1^{\text {th }}$ ed. [S.I.: s.n.], 1910-1911. p. 108-116. (v. XXIII)

COLAPIETRO, Vincent M. Glossary of semiotics. New York: Paragon House, 1993.

Peirce's approach to the self: a semiotic perspective on human subjectivity. New York: State University of New York Press, 1989.

COLPITT, Frances. Kiefer as occult poet. Art in America, New York, v.1, n. 3, p. 104-111, mar. 2006.

COOPER, Thomas; HILL, Paul. Dialogue with photography. Stockport: Dewi Lewis Publishing, 1998.

COUCHOT, Edmond. A tecnologia na arte, da fotografia à realidade virtual. Tradução Sandra Rey. Rio Grande do Sul: UFRGS, 2003.

CRIMP, Douglas. Pictures. October, New York, v.1, n. 8, p. 75- 78, spring 1979.

The photographic activity of postmodernism. October, New York, v.1 n. 15, p. 91-101, winter 1980.

CROW, Nancy. Quilts and influence. New York: American Quilter's Society, 1990.

DANTO, Arthur C. Symbolic expressions and the self. In: HOROWITZ, Gregg; HUHN, Tom. (Eds.). Arthur C. Danto: essays the wake of art, criticism, philosophy and the ends of taste. Amsterdam: G+B Arts International, 1998. p. 97-114.

The madonna of the future: essays in a pluralistic art world. Berkeley: University of California Press, 2001a.

Embodied meanings: critical essays and aesthetic meditations. New York:

Farrar Straus Giroux, 2007. 
After the end of art: contemporary art and the pale of history. Princeton: Princeton University Press, 1997a.

The state of the art. New York: Prentice Hall Press, 1987.

The artworld. Journal of Philosophy, New York, v. 61, n. 6, p. 571-584, 1964.

The philosophical disenfranchisement of art. New York: Columbia

University Press, 1986.

The transfiguration of the commonplace: a philosophy of art. Cambridge: Harvard University Press, 1981.

Narration and knowledge. New York: Columbia University Press, 1985.

Mysticism and morality: oriental thought and moral philosophy. New York:

Columbia University Press, 1988.

Encounters \& reflections: art in the historical present. New York: Farrar Straus Giroux, 1990.

Beyond the brillo box: the visual arts in post-historical perspective. New York: Farrar Straus Giroux, 1992.

Playing with the edge: the photographic achievement of Robert Mapplethorpe. Berkeley: University of California Press, 1996.

Connections to the world: the basic concepts of philosophy. Berkeley: University of California Press, 1997b. 2001b.

Philosophizing art: selected essays. Berkeley: University of California Press,

DAVIES, Penelope J. E. et al. Janson and Janson's basic history of western art. $7^{\text {th }}$ ed. Boston: Pearson Prentice Hall, 2005.

DEBRAY, Regis. Acreditar, ver, fazer. Tradução Eliana Maria de Mello Souza. São Paulo: Edusc, 2003.

Eleven europeans in America. Bulletin of the Museum of Modern Art, New York, v. 12, n. 4, 1946.

Vida y muerte de la imagen: historia de la mirada en Occidente. Barcelona: Paidós, 1994.

DELANEY, Cornelius F. Peirce sobre ciência e metafísica: visão geral de uma visão sinóptica. Cognitio, Revista de Filosofia, São Paulo: Centro de Estudos do Pragmatismo, Programa de Estudos Pós-Graduados da Pontifícia Universidade Católica de São Paulo, Angra EDUC, v. 1, n. 3, p. 13-21, nov. 2002. 
DELEUZE, Gilles; GUATTARI, Felix. O que a Filosofia? Tradução de Bento Prado Jr.; Alberto Alonso Muñoz. Rio de Janeiro: Editora 34, 1992.

Mil platôs: capitalismo e esquizofrenia. Tradução Aurélio Guerra Neto;

Cecília Pinto Costa. Rio de Janeiro: Editora 34, 1997.

DELEUZE, Gilles. El pliegue. Barcelona: Paidós, 1988.

DE MAN, Paul. A letter. Critical Inquiry. v. 8, n. 3, p. 509-513, spring 1982.

DENES, Agnes. The artist as universalist. Ithaca: Herbert F. H. Johnson Museum of Art: Cornell University Press, 1992.

DERRIDA, Jacques. Of grammatology. Translated with an introduction by Gayatri C. Spivak. Baltimore: John Hopkins University Press, 1976.

DERRIDA, Jacques et al. Deconstruction and criticism. New York: Seabury Press, 1979.

DERRIDA, Jacques. Writing and difference. Chicago: University of Chicago Press, 1978.

Positions. Translated by A. Bass. Chicago: University of Chicago Press, 1981.

On the line. New York: Columbia University Press, 1983.

The truth in painting. Translated by G. Bennington; I. McLeod. Chicago:

University of Chicago Press, 1987.

DETIENNE, Marcel. Os mestres da verdade na Grécia arcaica. Tradução Andréa Daher. Rio de Janeiro: Jorge Zahar, 1981.

DERY, Mark. Escape velocity: cyberculture at the end of the century. New York: Groove Press, 1996.

DEWEY, John. Art as experience. New York: The Berkeley Publishing Group, 1980.

DIDI-HUBERMAN, Georges. Devant le temps: histoire de l'art et anachronisme des images. Paris: Minuit, 2000.

DRUCKER, Johanna. Photography after photography. Art Journal. v. 58, p. 107-111, 22 mar. 1999.

DUBOIS, Philippe. O ato fotográfico e outros ensaios. São Paulo: Papirus, 1994.

DUCKREY, Timothy. History theory and practice. Cambridge: The MIT Press, 2000.

DUVE, Thierry de. Kant after Duchamp. Cambridge: The MIT Press, 1998. 
ECO, Umberto. Obra aberta: forma e indeterminação nas poéticas contemporâneas. 8. ed. São Paulo: Perspectiva, 1991a.

A estrutura ausente. Tradução de Pérola de Carvalho. São Paulo:

Perspectiva, 1976.

A theory of semiotics. Bloomington: Indiana University Press, 1976.

The role of the reader. London: Hutchinson, 1981.

O signo de três. São Paulo: Perspectiva, 1991b.

Le pendule de Foucault. Paris: Le Livre de Poche, 2002.

ECO, Umberto; SEBEOK, Thomas. A definição da arte. Lisboa: Martins Fontes, 1986.

ELIOT, Thomas Stearns. Four quartets. London: Faber and Faber, 1986.

Collected poems, 1909-1962. San Diego: Harcourt Brace Jovanovich Publishers, 1988.

ELSE, F. G. Aristotle's poetics: the argument. Cambridge: Harvard University Press, 1967.

EMERSON, Ralph Waldo. Nature. In: ___. Essays and Lectures. $7^{\text {th }}$ ed. New York: Literary Classics of United States Inc., 1983a. p. 9-49.

Essays and lectures. $7^{\text {th }}$ ed. New York: Literary Classics of United States Inc., 1983b.

ENGBERG, Siri; NOCHLIN, Linda; WARNER, Marina. Kiki Smith: a gathering, 1980-2005. San Francisco: San Francisco Museum of Modern Art, 2005.

ENWEZOR, Okwui. Gabriel Orozco: silencios infinitos. Atlántica Internacional, Revista de Arte y Pensamiento, Centro Atlántico de Arte Moderno, Las Palmas de Gran Canária, n. 17, v. 1, p. 20-30, dez.1997.

Archive fever: photography between history and the monument. Archive Fever, New York: ICP/Steidl, p. 11-47, 2008.

ERICKSON, Victoria Lee. On the town with Georg Simmel: a socio-religious understanding of urban interaction. Cross Currents, New York, v. 51, n. 1, spring 2001.

EVERAERT-DESMEDT, N. Interpréter l'art contemporain. Brussells: De Boeck, 2006.

Le processus interprétatif: introduction à la sémiotique de Ch. S. Peirce.

Liège: Mardaga, 1990. 
FAIRCLOUGH, H. Rushton. Virgil: Aeneid VII-XII. The minor poems. v. 2. Translated by Loeb Classical Library. London: William Heineman, 1969.

FINEBERG, Jonathan. Art since 1940: strategies of being. New York: Prentice Hall, Inc., 1996.

FISCH, M. H. Peirce, semeiotic and pragmatism. Bloomington: Indiana University Press, 1986.

FLAUBERT, Gustave. Le dictionnaire des idées reçues. Paris: Jean Aubier, 1870.

FLEMING, John; HONOUR, Hugh. The visual arts: a history. $4^{\text {th }}$ ed. New Jersey: Prentice Hall, 1995.

FLUSSER, Vilém. Filosofia da caixa preta: ensaios para uma futura filosofia da fotografia. São Paulo: Hucitec,1985.

FOSTER, Hal. (Ed.). Postmodern culture. London: Pluto Press, 1983.

FOSTER, Hal. Vision and visuality. Seattle: Bay Press, 1988.

The return of the real: the avant-garde at the end of the century,

Cambridge: The MIT Press, 1997.

Richard Serra: sculpture, 1985-1998. Los Angeles: Museum of Contemporary Art, 1998.

Richard Serra: torqued spirals, toruses and spheres. New York: Gagosian Gallery, 2001.

FOSTER, Hall. (Ed.). The anti-aesthetic: essays on postmodern culture. New York: The New Press, 1998.

FOSTER, Hal; HUGHES, Gordon. (Eds.). Richard Serra. Cambridge: The MIT Press, 2000.

FOUCAULT, Michel. Of other spaces. Diacritics, New York, v. 16, n. 1, p. 22-27, spring 1986.

The archeology of knowledge. Translated by A. M. Sheridan Smith. New York: Pantheon Books, 1972.

The order of things. New York: Random House, 1969.

O que é um autor? Lisboa: Vega, 1992.

Microfísica do poder. 11. ed. Rio de Janeiro: Graal, 1993.

Vigiar e punir: o nascimento da prisão. 11. ed. Rio de Janeiro, Vozes, 1994. 
FOUCAULT, Michel. The return of the real: the avant-garde at the end of the century. Cambridge: The MIT Press, 1996.

FRANZ, M-L. V. Alquimia: introdução ao simbolismo e à psicologia. São Paulo: Cultrix, 1998.

FRASCINA, Francis. (Ed.). Pollock and after: the critical debate. New York: Harper and Row, 1985.

FREEDBERG, David. O poder da imagem. Lisboa: Edições 70, 1986.

FRIED, Michael. Art and objecthood. Chicago: The University of Chicago Press, 1998.

GABLIK, Suzan. The reenchantment of art. New York: Thames and Hudson, 1991.

GADAMER, Hans-Georg. Hermenêutica em retrospectiva: Heidegger em retrospectiva. Rio de Janeiro: Vozes, 2007. (v. 1)

Hermenêutica em retrospectiva: a virada hermenêutica. Rio de Janeiro:

Vozes, 2007. (v. 2)

GARDNER, Paul. Louise Bourgeois. New York: Universe, 1993.

GOETHE, J. W. The collected works: essays on art and literature. Princeton: Princeton University Press, 1994.

GOLDBERG, Vicki. The power of photography. Nova York: Abbeville Press, 1991. GOLDSTEIN, Ann. et al. A forest of signs: art in the crisis of representation. Los Angeles: The MIT Press, 1989.

GOLDSTEIN, Ann; RORIMER, Anne. (Eds.). Reconsidering the object of art: 1965-1975. Los Angeles: Museum of Contemporary Art: The MIT Press, 1995.

GOMBRICH, Ernst. The image and the eye: further studies in the psychology of pictorial representation. London: Phaidon Press, 1982.

GORDIN, Misha. Hidden: the conceptual photography of Misha Gordin. San Rafael: Earth Aware Editions, 2007.

GREENBERG, Clement. Modernist painting. In: The collected essays and criticism: modernism with a vengeance, 1957-1969. Chicago: University Of Chicago Press, 1960. (v. 4)

Toward a newer Laocoon. Partisan Review, New York, v. 7, n. 4, p. 296-310, jul./aug. 1940.

GUINSBURG, J. (Org.). A república de Platão. São Paulo: Perspectiva, 2006. 
GURDJIEFF, GEORGE IVANOVITCH. Meetings with remarkable men. New York: Routledge \& Kegan Paul, 1963.

HABERMAS, Jürgen. O discurso filosófico da modernidade. Lisboa: Dom Quixote, 1990.

(Ed.). Representation: cultural representations and signifying practices. London: Sage Publications, 1997.

HALL, Stuart. A identidade cultural na pós-modernidade. 3. ed. Rio de Janeiro: DP\&A, 1999.

HARAWAY, Donna. A cyborg manifesto: science, technology, and socialist feminism in the late twentieth century. In: Simians, cyborgs, and nature. New York: Routledge, 1991. p. 149-181.

HARRIS, Craig. (Ed.). Art and innovation. Cambridge: The MIT Press, 1999.

HARRISON, Charles; WOOD, Paul. (Eds.). Art in theory, 1900-2000: an anthology of changing ideas. Malden: Blackwell Publishers, 2002.

HASSAN, lhab. Prometheus as performer: towards a posthumanist culture? The Georgia Review, Athens: The University of Georgia, n. 31, p. 830-850, 1977.

HARTSHORNE, Charles; WEISS, Paul; BURKS, Arthur. (Eds.). Collected papers of Charles Sanders Peirce. 8 v. Cambridge: Harvard University Press, 1931-35; 1958.

HARVEY, David. Condição pós-moderna: uma pesquisa sobre as origens da mudança cultural. São Paulo: Loyola, 1992.

HAUSER, Arnold. Teorias da arte. 2. ed. Lisboa: Editorial Presença, 1988.

Philosophical perspectives on the study of creativity, frontiers of creativity research: beyond the basics. Bearly: S. Isaksen, 1987.

Metaphor and art: Interactionism in verbal in non-verbal arts. Cambridge: The MIT Press, 1989.

Charles S. Peirce's evolutionary philosophy. Cambridge: University Cambridge Press, 1993.

HAYLES, N. Katherine. How we became posthuman: virtual bodies in cybernetics, literature, and informatics. Chicago: University of Chicago Press, 1999.

HEARTNEY, Eleanor. Critical condition: American culture at the crossroads and postmodernism. Cambridge: Cambridge University Press, 2001.

HEIDEGGER, Martin. The origin of the work of art. In: ROSS, Stephen David. (Ed.). Art and its significance: an anthology of aesthetic theory. $2^{\text {th }}$ ed. Albany: State University of New York Press, 1987. p. 258-287. 
HEIDEGGER, Martin. Being and time. Translated by Joan Stambaugh. Albany: State University of New York Press, 1953.

An introduction to metaphysics. London: Yale University Press, 1959.

Introdução à metafísica. Rio de Janeiro: Tempo Brasileiro, 1967.

Poetry, language, thought. Translated by Albert Hofstadter. New York:

Harper and Row, 1975.

Carta sobre o humanismo. Tradução Rubens Eduardo Frias. São Paulo:

Editora Moraes, 1991.

Arte y poesía. 6. ed. México: Fondo de Cultura Economica, 1992.

Caminos del bosque. Madri: Alianza, 1995.

Ensaios e conferências. 2. ed. Tradução Emmanuel Carneiro Leão; Gilvan

Fogel; Marcia Sá Cavalcante Schuback. Petrópolis, RJ: Vozes, 2001.

A caminho da linguagem. Tradução Marcia Sá Cavalcante Schuback.

Petrópolis, RJ: Vozes, 2003.

Que é isto, a filosofia? Identidade e diferença. Tradução Ernildo Stein.

Petrópolis, RJ: Vozes, 2006.

HONNEF, Klaus. Arte contemporânea. Tradução Casa das Línguas. Kohn: Benedikt Taschen, 1994.

HOROWITZ, Greg; HUHN, Tom. (Eds.). Arthur C. Danto, essays: the wake of art, criticism, philosophy and the ends of taste. Amsterdam: G+B Arts International, 1998.

HOWES, G. Palm Sunday: myth, meaning and representation. In:

Anselm Kiefer: aperiatur terra. London: Jay Jopling: White Cube; Sydney: Art

Gallery of New South Wales, 2007.

HUGHES, Robert. American visions. New York: Random House, Inc., 1999.

The shock of the new. New York: Alfred A. Knopf, Inc., 1991.

HUYSSEN, Andreas. After the great divide: modernism, mass culture, postmodernism. Bloomington: Indiana University Press, 1986.

IBRI, Ivo Assad. Kosmos Noetos: a arquitetura filosófica de Charles Sanders Peirce. São Paulo: Perspectiva, 1992.

O paciente objeto da semiótica. O falar da linguagem, São Paulo: Lovise, v. 2, n. 2, p. 115- 119, 1996. (Série Linguagem). 
INWOOD, Michael. Dicionário Heidegger. Tradução Márcia Sá Cavalcante Schuback. Rio de Janeiro: Zahar, 2002.

JAMES, William. Pragmatism and the meaning of truth. Cambridge: Harvard University Press, 1975.

JAUSS, Hans Robert. $O$ prazer estético e as experiências fundamentais da poiesis, aisthesis e katharsis. In: LIMA, Luis Costa. (Org.). A literatura e o leitor: textos de estética da recepção. Rio de Janeiro: Paz e Terra, 1979. p. 67-84.

JUDD, Don. Specific objects. In: ARTS yearbook: contemporary sculpture. New York: Art Digest, 1965.

JUDOVITZ, Dalia. Unpacking Duchamp: art in transit. Berkeley: University of California Press, 1995.

KANDINSKY, Wassily. Do espiritual na arte. 2. ed. Lisboa: Dom Quixote, 1996. Ponto e linha sobre o plano. São Paulo: Martins Fontes, 1997.

.; LINDSAY, Kenneth C.; VERGO, Peter. (Eds.). Kandinsky: complete writings on art. Boston: G. K. Hall, 1982.

Olhar sobre o passado. Tradução Antonio de Pádua Danesi. São Paulo: Martins Fontes, 1991.

KANT, Immanuel. Observations on the feeling of the beautiful and sublime.

Translated by John T. Goldthwait. Berkeley: University of California Press, 2003.

KAPROW, Allan. The legacy of Jackson Pollock. Artnews, New York, v. 57, n. 6 , p. 55-57, oct. 1958.

\section{3.}

. Essays on the blurring of art and life. Berkeley: University of California Press,

The education of the un-artist and just doing. In. Essays on the blurring of art and life. Berkeley: University of California Press, 1993. p. 110-126. KENT, Beverley. Charles Sanders Peirce: logic and the classification of the sciences. Kingston: McGill-Quenn's University Press, 1987.

KLEE, Paul. The diaries of Paul Klee: 1898-1918. Los Angeles: The University of California Press, 1968.

KOSSLYN, Stephen. Image and brain. Cambridge: The MIT Press, 1996.

KRAUSS, Rosalind. The originality of the avant-garde and other modernist myths. Cambridge: The MIT Press, 1985. 
KRAUSS, Rosalind. Caminhos da escultura moderna. Tradução Julio Fischer. 2. ed. São Paulo: Martins Fontes, 2001.

Sculpture in the expanded field. In: FOSTER, Hall. (Ed.). The anti-aesthetic: essays on postmodern culture. New York: The New Press, 1990. p. 31-42.

The optical unconscious. Cambridge: The MIT Press, 1998.

KRAUSS, Rosalind et al. October: the second decade, 1986-1996. Cambridge: The MIT Press, 1997.

KRAUSS, Rosalind. Bachelors. Cambridge: The MIT Press, 1999.

The originality of the avant-garde: a postmodernist repetition. In: WALLIS, Brian. (Ed.). Art after modernism: rethinking representation. New York: New Museum of Contemporary Art; Boston: David R. Godine, 1991. p. 13-29.

Cindy Sherman. New York: Rizzoli International Publications, 1993.

KRAUSS, Rosalind et al. October: the first decade, 1976-1986. Cambridge: The MIT Press, 1987.

KUHN. Thomas, S. The structure of scientific revolutions. Chicago: University of Chicago Press, 1962.

KUSPIT, Donald B. Flak from the "radicals": the American case against current German painting. In. WALLIS, Brian. (Ed.). Art after modernism: rethinking representation. New York: New Museum of Contemporary Art; Boston: David R. Godine, 1991. p. 137-151.

Signs of the psyche in modern and post-modern art. New York: Cambridge University Press, 1993.

KWON, Miwon; STORR, Robert; AULT, Julie. (Eds.). Felix Gonzalez-Torres. Germany: Steidl Dangin, 2006.

LAGARDE, Georges de. L'idée de representation. International Committee of the Historical Sciences Bulletin, New York, v. 1, n. 9, p. 425-451, dec. 1937.

LAGNADO, Lisette. (Org.). São tantas as verdades: Leonilson. São Paulo: Dba, 1999.

LAURY, Jean Ray. Applique stitchery. New York: Van Noststrand Reinhold Publ., 1966.

LAWRENCE, D. H. Morality and the novel. In: HERBERT, Michael (Ed.).

Selected critical writings. New York: Oxford University Press, 1998.

LEÃO, Lucia. A estética do labirinto. São Paulo: Anhembi Morumbi, 2002. 
LÉVINAS, Emmanuel. Entre nós: ensaios sobre a alteridade. Petrópolis, RJ: Vozes, 2004.

LÉVY, Pierre. O que é o virtual. São Paulo: Editora 34, 1996.

LeWITT, Sol. Paragraphs on conceptual art. Artforum, New York, v. 5, n. 10, p. 79-83, jun. 1967.

Sentences on conceptual art, 1969. In. SANDLER, Irwing. Art of the postmodern era: from the late 1960s to the early 1990s. New York: Harper Collins, 1996. p. 11-12.

LILLEMOSE, Jacob. Conceptual transformation of art: from dematerialization of the object to immateriality in networks. In: KRYSA, Joasia. (Ed.). Curating immateriality. New York: Autonomedia, 2006. p. 113-135.

LIPOVETSKI, Gilles. A era do vazio. Lisboa: Relógio D’Água, 1990.

LIPPARD, Lucy R. The lure of the local: senses of place in a multicentered society. New York: New Press, 1997a.

Six years: the dematerialization of the art object from 1966 to 1972.

Berkeley: The University of California Press, 1997b.

Mixed blessings: new art in a multicultural America. New York: Pantheon Books, 2000.

LIPPARD, Lucy R.; CHANDLER, John. Changing: essays in art criticism. New York: Dutton, 1971.

Contemporary art and the art of prehistory. New York: The New Press, 1983.

___ Pop art. London; New York: Thames and Hudson, 1992.

The pink glass swan: selected feminist essays on art. New York: New York Press, 1995.

Blurring the boundaries: instalation art, 1969-1996. San Diego: Museum of Contemporary Art, 1997.

LOWINGER, Rosa. El objeto protagonista: una entrevista con Los Carpinteros Alexandre Arrechea, Marco Castillo and Dagoberto Rodriguez. Sculpture Magazine, New York, v. 18, n. 10, dec. 1999.

LUBISCO, Nídia M.; SANTANA, Isnaia Veiga; VIEIRA, Sônia C. Manual de estilo acadêmico: monografias, dissertações e teses. 4. ed. Salvador: Edufba, 2007.

LUNFELD, Peter. The digital dialectic: new essays on new media. Cambridge: The MIT Press, 1999. 
MACHADO, Arlindo. A ilusão especular. São Paulo: Brasiliense, 1984.

Anamorfoses cronotópicas ou a quarta dimensão da imagem. In:

PARENTE, André. (Org.). Imagem-máquina: a era das tecnologias do virtual. São

Paulo: Editora 34, 2001. p. 100-116.

MAINARDI, Patricia. Quilts: the great american art. Feminist Art Journal, New York, v. 2. n. 1, p. 18-23, winter 1973.

MALEVICH, Kasimir. The non-objective world: the manifesto of suprematism. Translated by Howard Dearstyne. Chicago: Paul Theobald Co., 1959.

MANOVICH, Lev. The language of new media. Cambridge: The MIT Press, 2001.

MANGUEL, Alberto. Lendo imagens: uma história de amor e ódio. 2. ed. Tradução Rubens Figueiredo; Rosaura Eichemberg; Cláudia Strauch. São Paulo: Companhia das Letras, 2003.

MARCUSE, Herbert. A dimensão estética. São Paulo: Martins Fontes, 1986.

McEVILLEY, Thomas. Philosophy in the land: since the 1960s. Art in America, New York, v. 92, n. 10, p. 158-163, Nov.1. 2004.

McHALE, John. The fine arts in the mass media. In: STILES, Kristine; SELZ, Peter. (Eds.). Theories and documents of contemporary art: a sourcebook of artists' writings. Berkeley: University of California Press, 1996. p. 282.

McMORRIS, Penny; KILE, Michael. The art quilt. San Francisco: The Quilt Digest Press, 1996.

MILNER, John. Kasimir Malevich and the art of geometry. New Haven: Yale University Press, 1996.

MITCHELL, William J. The reconfigured eye: visual truth in the postphotographic era. Cambridge: The MIT Press, 1994.

Iconology: image, text, ideology. Chicago: Chicago University Press, 1986.

MONDRIAN, Piet. Eleven europeans in America. Bulletin of the Museum of Modern Art, New York: Museum of Modern Art (MoMA), v. XII, n. 4, 5, p. 35-36, 1946.

MORIN, Edgar. Cultura de massa no século XX. Rio de Janeiro: Forense Universitária, 1989. (v. 1)

MORRIS, Robert. Notes on sculpture, part 2. Artforum, New York, v. 5, n. 2, p. 20-23, oct. 1966. 
MOSQUERA, Gerardo. (Org.). Beyond the fantastic: contemporary art criticism from Latin America. Cambridge: The MIT Press, 1996.

NÉRET, Gilles. Kazimir Malevich and suprematism: 1878-1935. New York: Taschen, 2003.

NEWHALL, Beaumont. The history of photography: from 1839 to the present. New York: The Museum of Modern Art, 1982.

NEWMAN, Michael. Mimesis and abjection in recent photowork. In: BENJAMIN, Andrew;

OSBORNE, Peter. (Eds.). Thinking art: beyond traditional aesthetics. London: Institute of Contemporary Arts, 1991. p. 111-127.

NÖTH, Winfried. Panorama da semiótica: de Platão a Peirce. São Paulo: Annablume, 1995a. Handbook of semiotics. Bloomington: Indiana University Press, 1995b. A semiótica no século XX. São Paulo: Annablume, 1996.

NOVALIS, F. Von H. Os hinos à noite. Tradução Fiama Hasse Pais Brandão. Lisboa: Assírio \& Alvim, 1988.

O'DOHERTY, Brian. Inside the white cube: the ideology of the gallery space. Los Angeles: University of California Press, 1999.

OSBORNE, Peter. Modernism, abstraction, and the return to painting. In: BENJAMIN, Andrew; OSBORNE, Peter. (Eds.). Thinking art: beyond traditional aesthetics. London: Institute of Contemporary Arts, 1991b. p. 59-79.

OWENS, Craig. The discourse of others: feminists and postmodernism. In: FOSTER, Hall. (Ed.). The anti-aesthetic: essays on postmodern culture. New York: The New Press, 1998. p. 57-82.

PALMER, Richard E. Hermeneutics: interpretation theory in Schleiermacher, Dilthey, Heidegger and Gadamer. Evanston: Northwestern University Press, 1985. p. 194-217.

PAUL WOOD et al. Modernism in dispute: art since the fourties. Yale: Yale University Press, 1994.

PEDROSA, Adriano. Voilà mon coeur. In: LAGNADO, Lisette. (Org.). São tantas as verdades: Leonilson. São Paulo: Dba, 1999. p. 18-26.

PEIRCE, Charles Sanders. Semiótica. Tradução José Teixeira Coelho Neto. 3. ed. São Paulo: Perspectiva, 2005. 
PEIRCE, Charles Sanders. Semiótica e filosofia. Tradução Octanny S. da Mota; Leônidas Hegenberg. São Paulo: Cultrix, 1972.

Semiotic and significs: the correspondence between Charles S. Peirce and

Victoria Lady Welby. Bloomington: Indiana University Press, 1977.

Writings of Charles S. Peirce: a chronological edition, 1857-1866.

Bloomington: Indiana University Press, 1982. (v. 1)

The essential Peirce: selected philosophical writings, 1867-1893.

Bloomington: Indiana University Press, 1992. (v. 1)

The electronic edition of the collected papers of Charles Sanders Peirce.

Utah: Folio Corporation: Harvard University Press, 1994. (v. I - VIII)

The essential Peirce: selected philosophical writings, 1893-1913. Bloomington:

Indiana University Press, 1998. (v. 2)

PENROSE, Roland. Man Ray. Boston: New York Graphic Society, 1975.

PERLOFF, Marjorie. From Frank O'Hara: poet among painters. Chicago:

University of Chicago Press, 1997.

PINCUS-WITTEN, Robert. Postminimalism into maximalism: American art, 19661986. Ann Arbor: UMI Research Press, 1987.

PITKIN, Hanna Fenichel. The concept of representation. Berkeley: University of California Press, 1967.

PLOTINUS. Complete works. 5 v. Alphine: Platonist Press, 1918.

The enneads. New York: Penguin Classics, 1991.

POPPER, Frank. Art of the eletronic age. London: Thames and Hudson, 1993.

PROUST, Marcel. Contre Sainte-Beuve. Paris: Pléiade, 1905.

RAMIREZ, Mari Carmen. Blue-print circuits: conceptual art and politcs. In: RASMUSSEN, Waldo. (Ed.). Latin american art of the twentieth century. New York: The Museum of Modern Art, 1992. p. 156-167.

Rematerialization. Universalis: Bienal Internacional de São Paulo, XIII, São Paulo, Fundação Bienal de São Paulo, 1996a. p. 178-189.

Beyond the fantastic: framing identity in US exhibitions of Latin American art. In. MOSQUERA, Gerardo. (Ed.). Beyond the fantastic: contemporary art criticism from Latin America. Cambridge: The MIT Press, 1996b. p. 229-247.

RANSDELL, Joseph. Another interpretation of Peirce's semiotic.

TRANSACTIONS, Charles S. Peirce Society, v. 6, n. 2, p. 67-83, 1996. 
RATCLIFF, Carter. Out of the box: the reinvention of art, 1965-75. New York: Allworth Press: School of Visual Arts, 2000.

REIMSCHNEIDER, Burkhard; GROSENICK, Uta. Art at the turn of the millennium. Colonia: Taschen, 1999.

RILEY II, Charles A. Color codes. $5^{\text {th }}$ ed. Hanover: University Press of New England, 1995.

ROBINS, Corinne. The pluralist era: American art, 1968-1981. New York: Harper and Row, 1984.

ROSE, Barbara. Kiefer's cosmos. Art in America, New York, 1998.

Disponível em: <http://findarticles.com/p/articles/mi_m1248/is_12_86/ ai_53408955/?tag=content;col1>. Acesso em: 2007.

ROSENBERG, Harold. Rosenberg's anthology of essays: the tradition of the new. New York: Horizon Press, 1959.

ROSENTHAL, Mark; SPEYER, James. Anselm Kiefer. Chicago: Philadelphia Museum Of Art: The Art Institute of Chicago, 1987.

ROSENSTOCK, Laura. (Ed.). Richard Serra: sculpture. New York: The Museum of Modern Art, 1986.

ROSS, Stephen David. (Ed.). Art and its significance: an anthology of aesthetic theory. $2^{\text {th }}$ ed. Albany: State University of New York Press, 1987.

ROSS, Stephen David. Bill Viola - a 25-year survey. Catalogue of San Francisco Museum of Modern Art, 1999, p. 2.

SALLES, Cecília. Redes da criação: construção da obra de arte. São Paulo: Horizonte, 2006a.

Gesto inacabado: processo de criação artística. 2. ed. São Paulo: Annablume, 2006b.

SANDLER, Irwing. Art of the postmodern era: from the late 1960s to the early 1990s. New York: Harper Collins, 1996.

SANTAELLA, Lucia. Linguagens líquidas na era da mobilidade. São Paulo: Paulus, 2007.

Estética: de Platão a Peirce. 2. ed. São Paulo: Experimento, 2000a.

O que é semiótica. São Paulo: Brasiliense, 1983.

Matrizes da linguagem e do pensamento: sonora, visual, verbal. São Paulo: lluminuras, 2001. 
SANTAELLA, Lucia. A teoria geral dos signos: como as linguagens significam as coisas. 2. ed. São Paulo: Pioneira, 2000b.

SANTAELLA, Lucia; NÖTH, Winfried. Imagem: cognição, semiótica, mídia. São Paulo: lluminuras, 1997. Comunicação e semiótica. São Paulo: Hacker, 2004.

SANTAELLA, Lucia. Semiótica aplicada. São Paulo: Thompson, 2002.

O método anticartesiano de C. S. Peirce. São Paulo: UNESP, 2004a.

A assinatura das coisas: Peirce e a literatura. Rio de Janeiro: Imago, 1992.

Cultura e artes do pós-humano: da cultura das mídias à cibercultura.

São Paulo: Paulus, 2003a.

Por uma classificação da linguagem visual. FACE, São Paulo: Educ, v. 2, n. 1, p. 43-67, 1989.

Por que as comunicações e as artes estão convergindo? São Paulo: Editora Paulus, 2005.

Corpo e comunicação: sintoma da cultura. São Paulo: Paulus, 2004b. Teoria geral dos signos: semiose e autogeração. 2. ed. São Paulo: Ática, 1995.

Percepção: uma teoria semiótica. São Paulo: Experimento, 1993.

Cultura das mídias. São Paulo: Experimento, 1996.

Contribuições do pragmatismo de Peirce para o avanço do conhecimento. Revista de Filosofia, Curitiba, v. 16, n. 18, p. 75-86, jan/jun. 2004.

SANTAELLA, Lucia; BARROS, A. Mídias e artes: o desafio da arte no século XXI. São Paulo: Unimarco, 2002.

SANTAYANA, G. Reason in religion: the life of reason. New York: Collier, 1962.

SARUP, Madan. An introductory guide to post-structuralism and postmodernism. Athens: University of Georgia Press, 1989.

SAVAN, D. An introduction to C.S. Peirce's system of semeiotic. Toronto: Victoria College in University of Toronto, 1988.

SCHAPIRO, Meyer. Theory and philosophy of art: style, artist, and society.

New York: George Braziller, 1994. 
SCHELLING, F. W. J. Idéias para uma filosofia da natureza. Tradução Carlos Morujão. Lisboa: Centro de Filosofia da Universidade de Lisboa: Imprensa Nacional Casa da Moeda, 2001a.

Filosofia da arte. Tradução Mário Suzuki. São Paulo: Edusp, 2001b.

SCHIER, Flint. Deeper into pictures: an essay on pictorial representation. New York: Cambridge University Press, 1986.

SCHIMMEL, Paul. Out of actions: Between performance and the object, 19491979. New York: The Museum of Contemporary Art: Thames and Hudson, 1998.

SCHLEGEL, F. Conversa sobre poesia e outros fragmentos. Tradução VictorPierre Stirnimann. São Paulo: lluminuras, 1984.

SCHOPENHAUER, Arthur. Metafísica do belo. Tradução Jair Barbosa. São Paulo: Unesp, 2003.

SCHREYACH, Michael. I am nature: science and Jackson Pollock. Apollo, The International Magazine of Arts, New York, v. 1, n. 545, p. 35-43. jul./aug. 2007.

SELZ, Peter. Beyond the mainstream: essays on modern and contemporary art. Berkeley: University of California Press, 1996.

SERRA, Richard. Torqued ellipses. New York: Dia Center for the Arts, 1997.

SHARP, Dennis. The illustrated encyclopedia of architects and architecture. New York: Quatro Publishing, 1991.

SIEGEL, Jeanne. After Sherrie Levine [interview]. Arts Magazine, New York, vol. 59, n. 10, p. 141-144, jun. 1985.

SMITH, Roberta. Rolled and forged: art in review, Richard Serra. New York: Gagosian Gallery, 2006.

SMITHSON, Robert. A sedimentation of the mind: earth projects (1968). In: KASTNER, Jeffrey. (Ed.). Land and environmental art. London: Phaidon Press, 1998. p. 215-218.

SOLOMON-GODEAU, Abigail. Photography after art photography. In: WALLIS, Brian. (Ed.). Art after modernism: rethinking representation. New York: New Museum of Contemporary Art; Boston: David R. Godine, 1991. p. 75-85.

SONTAG, Susan. Ensaios sobre fotografia. Rio de Janeiro: Arbor, 1981.

Sobre a fotografia. Tradução Rubens Figueiredo. São Paulo: Companhia das Letras, 2005.

SPIES, Werner. Focus on art. New York: Rizzoli, 1982. 
STANGOS, Nikos. Conceitos da arte moderna. Tradução Álvaro Cabral. Rio de Janeiro: Jorge Zahar, 2000.

Concepts of modern art. From fauvism to postmodernism. London; New York: Thames and Hudson, 1994.

STEINBERG, Leo. Jasper Johns: the first seven years of his art. New York: Oxford, 1972.

STIEGLITZ, Alfred. The eloquent eye. In: ADATO, Perry Miller. American masters. DVD, NTSC (88 min). [S.I.]: Studio Winstar, July 10, 2001.

STILES, Kristine; SELZ, Peter. (Eds.). Theories and documents of contemporary art: a sourcebook of artists' writings. Berkeley: University of California Press, 1996.

STRICKLAND, Carol. Arte comentada: da pré-história ao pós-moderno. São Paulo: Ediouro, 1995.

TAYLOR, Joshua C. Learning to look: a handbook for the visual arts. $2^{\text {th }}$ ed. Chicago: The University of Chicago Press, 1981.

TCHEKHOVITCH, Tcheslaw. Gurdjieff, a master in life. Toronto: Dolmen Meadow Editions, 2006.

TUCKER, William. A linguagem da escultura. Tradução Antonio Manfredinni. São Paulo: Cosac \& Naify, 1999.

ULMER, Gregory L. The object of post-criticism. In: FOSTER, Hal. The antiaesthetic: essays on postmodern culture. $2^{\text {th }}$ ed. New York: New Press, 1998. p. 83-110.

VALDIVIESO, Mercedes. La Bauhaus de festa: 1919-1933. Spain: Fundacion La Caixa de Pensiones, 2005.

VAUDEVILLE, Charlotte. (Ed.). A weaver named Kabir: selected verses with a detailed biographical and historical Introduction. New York: Oxford Univercity Press, 1998.

VIRGÍlIO. A eneida. Tradução João Felix Pereira. Lisboa: Typ. Bibliotheca Universal, 1879.

VIRILIO, Paul. Estética de la desaparición. Barcelona: Anagrama, 1988. O espaço crítico. Rio de Janeiro: Editora 34, 1993.

WALLIS, Brian. (Ed.). Art after modernism: rethinking representation. New York: New Museum of Contemporary Art; Boston: David R. Godine, 1991.

WARREN, Beth Gates. Margrethe Mather \& Edward Weston: a passionate collaboration. New York: W. W. Norton \& Co., 2001. 
WEBER, Max. Ensaios de sociologia. Tradução Waltensir Dutra. 5. ed. Rio de Janeiro: Guanabara, 1982.

WEINER, Lawrence. Reconsidering the object of art: 1965-1975. Los Angeles: Museum of Contemporary Art; ArtForum, 1996.

WEIERMAIR, Peter. (Ed.). Louise Bourgeois. Zurich: Edition Stemmle, 1995.

WILSON, Victoria. (Ed.). Le Corbusier: architect of the century. London: Arts Council of Great Britain, 1987.

WINES, Leslie. Rumi: a spiritual biography. New York: Crossroads, 2001.

WITTGENSTEIN, Ludwig. Philosophical investigations. Translated by G. E. M. Anscombe. $3^{\text {th }}$ ed. New York: Macmillan, 1968.

WITTKOWER, Rudolf. Escultura. Tradução Jefferson Luiz Camargo. 2. ed. São Paulo: Martins Fontes, 2001.

WOOD, Paul et al. Modernismo em disputa: a arte desde os anos quarenta. São Paulo: Cosac\&Naify, 1998.

WOOD, Paul. Conceptual art. London: Tate Publishing, 2002.

WOODS, G.; THOMPSON, P., WILLIAMS, J. Art without boundaries. London: Thames and Hudson, 1972.

WORTZ, Melinda. In consideration. New York: Hudson River Museum, 1981. 



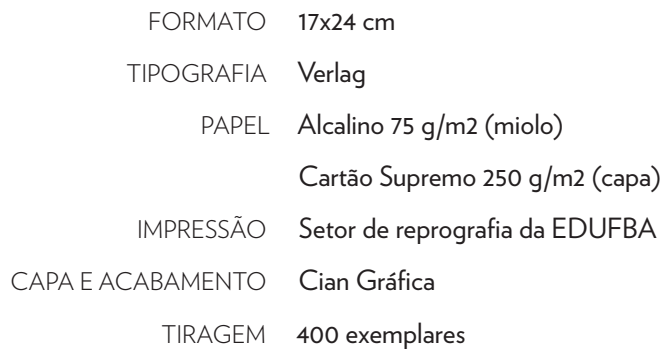

